\title{
Charakterisierung des mRNA-Exportweges bei zellulärem Stress in Saccharomyces cerevisiae
}

\section{Dissertation}

Zur Erlangung des mathematisch-naturwissenschaftlichen Doktorgrades

\author{
"Doctor rerum naturalium" \\ der Georg-August-Universität Göttingen \\ im Promotionsprogramm der \\ „Georg-August University School of Science” (GAUSS) \\ vorgelegt von \\ Lysann Bender \\ (geb. Henker) \\ aus Freiberg
}

Göttingen, Mai 2016 


\section{Betreuungsausschuss:}

Prof. Dr. Heike Krebber

Abteilung Molekulare Genetik

Institut für Mikrobiologie und Genetik

Prof. Dr. Gerhard Braus

Abteilung Molekulare Mikrobiologie und Genetik

Institut für Mikrobiologie und Genetik

\section{Mitglieder der Prüfungskommission:}

Referentin: Prof. Dr. Heike Krebber

Abteilung Molekulare Genetik

Institut für Mikrobiologie und Genetik

Korreferent: Prof. Dr. Gerhard Braus

Abteilung Molekulare Mikrobiologie und Genetik

Institut für Mikrobiologie und Genetik

\section{Weitere Mitglieder der Prüfungskommission:}

PD Dr. Wilfried Kramer

Abteilung Molekulare Genetik

Institut für Mikrobiologie und Genetik

Prof. Dr. Stefanie Pöggeler

Abtleilung Genetik eukaryotischer Mikroorganismen

Institut für Mikrobiologie und Genetik

Jun.-Prof. Dr. Kai Heimel

Abteilung Molekulare Mikrobiologie und Genetik

- Mikrobielle Zellbiologie -

Institut für Mikrobiologie und Genetik

Dr. Oliver Valerius

Abteilung Molekulare Mikrobiologie und Genetik

Institut für Mikrobiologie und Genetik

Tag der mündlichen Prüfung: 28.06.2016 


\section{Inhaltsverzeichnis}

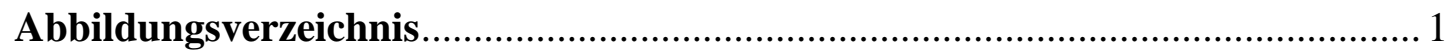

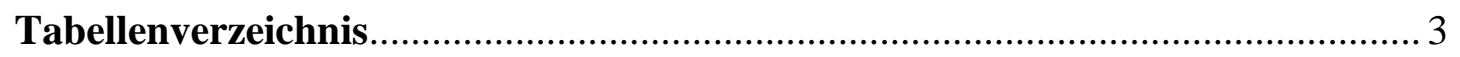

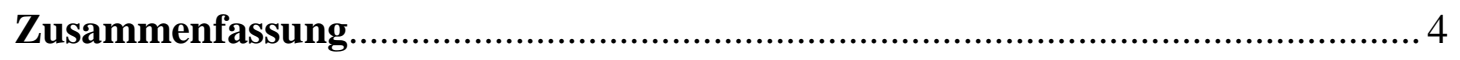

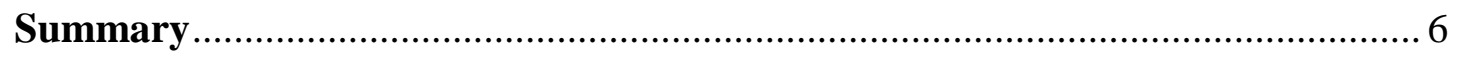

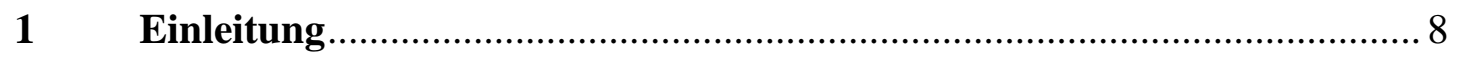

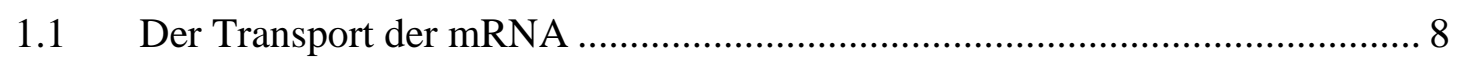

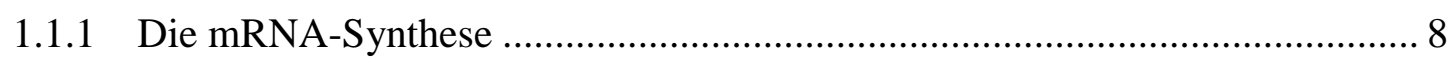

1.1.2 Die mRNPs werden vom Zellkern durch den Kernporenkomplex in das Zytoplasma transportiert ........................................................................ 13

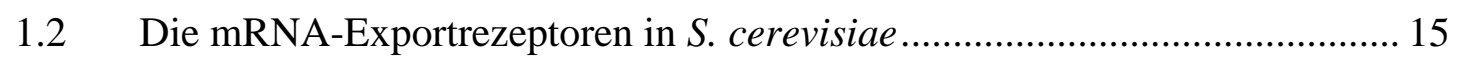

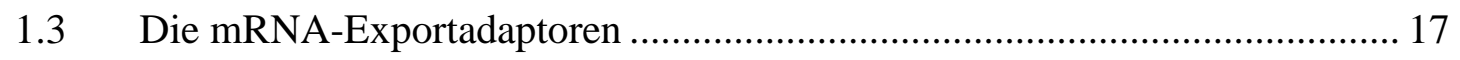

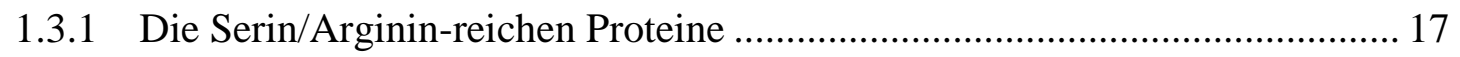

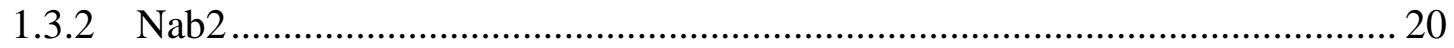

1.4 Die Qualitätskontrolle der reifenden mRNAs............................................ 22

1.4.1 mRNA-Qualitätskontrolle während der mRNA-Maturierung ....................... 22

1.4.2 mRNA-Qualitätskontrolle auf der nukleären Seite des NPCs ....................... 25

1.5 Der mRNA-Transport während zellulären Stresses.................................... 26

1.5.1 Die Kontrolle der Genexpression bei der Stressantwort ................................ 26

1.5.2 Regulation des mRNA-Metabolismus bei Stress.......................................... 30

1.6 Zielsetzung der vorliegenden Arbeit......................................................... 36

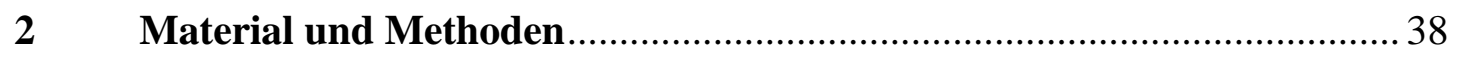

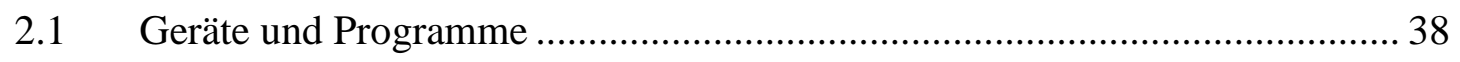

2.2 Chemikalien und Verbrauchsmaterialien............................................... 40

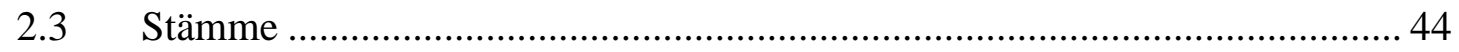

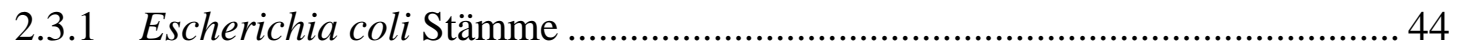

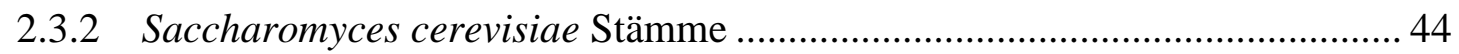




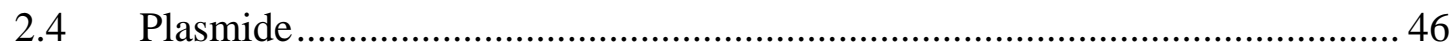

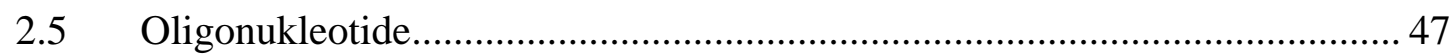

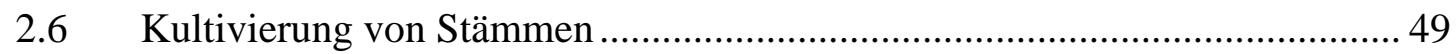

2.6.1 Kultivierung von E. coli Zellen ................................................................. 49

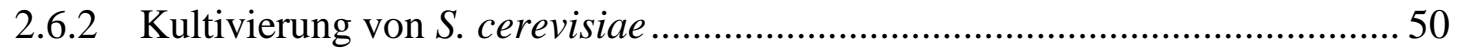

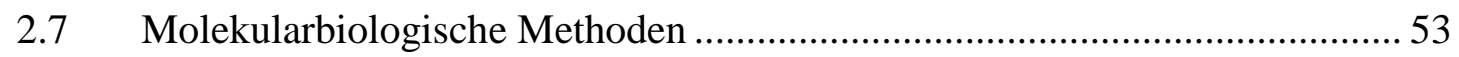

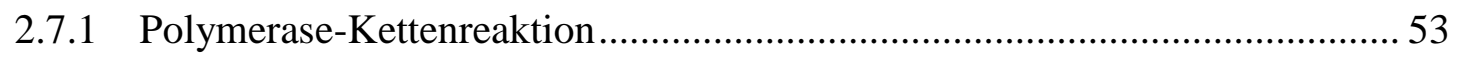

2.7.2 Agarose-Gelelektrophorese und DNA-Aufreinigung .................................. 54

2.7.3 Hydrolytische Spaltung von DNA durch Restriktionsendonukleasen ............. 55

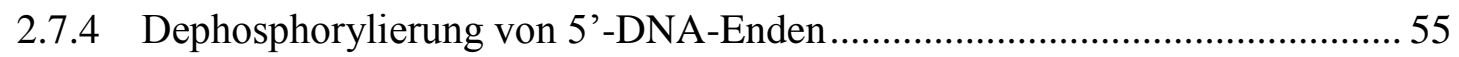

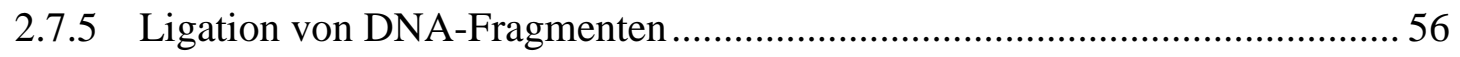

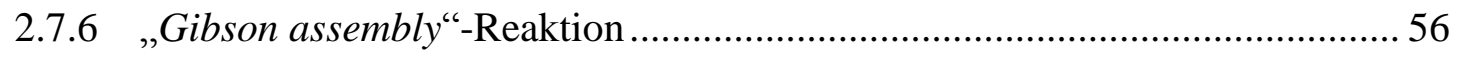

2.7.7 Transformation von E. coli Zellen mit Plasmid-DNA ................................... 57

2.7.8 Isolierung von Plasmid-DNA aus E. coli Zellen ......................................... 58

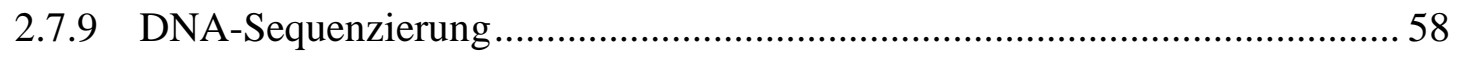

2.7.10 Herstellung der Plasmide pHK1279, pHK1417, pHK1418, pHK1419,

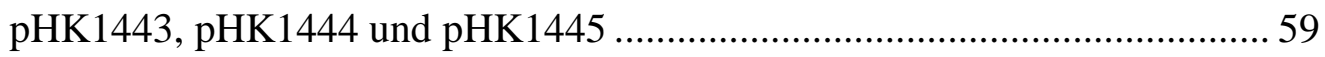

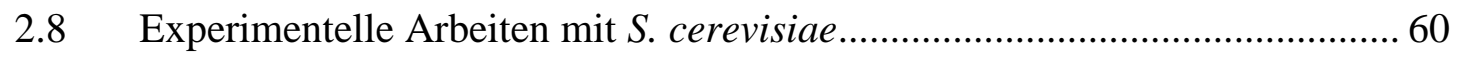

2.8.1 Verwendung von verschiedenen Stressbedingungen ................................... 60

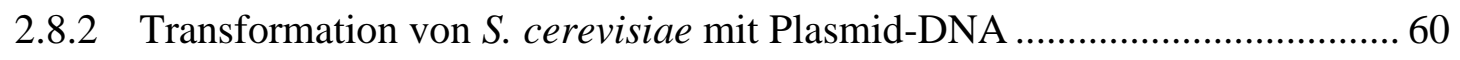

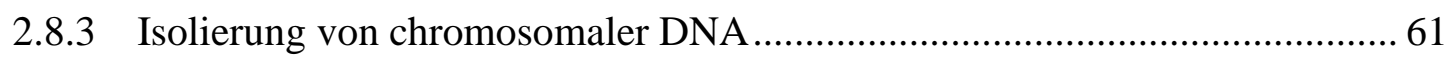

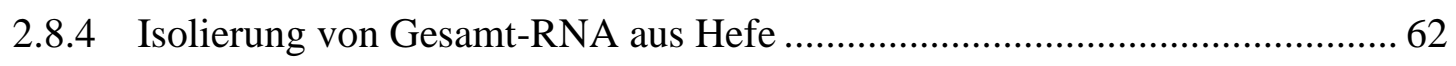

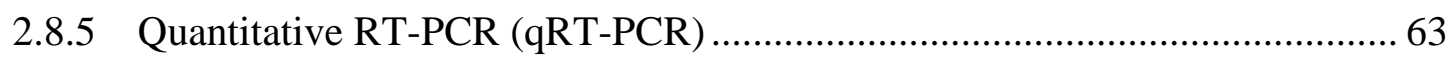

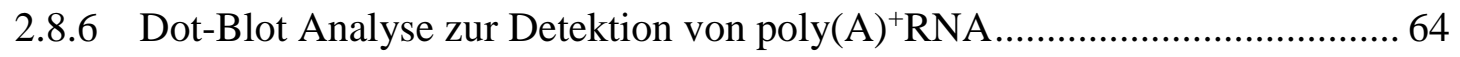

2.8.7 Synthese von Digoxigenin (DIG)-markierten RNA-Sonden .......................... 66

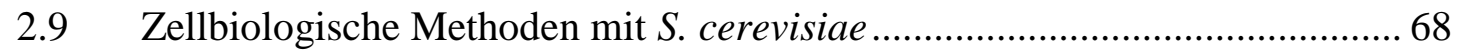

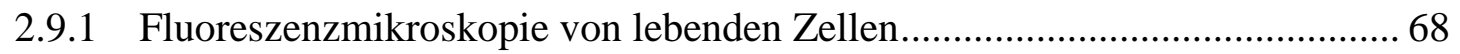


2.9.2 Fluoreszenz in situ Hybridisierungsexperimente 68

2.9.3 GFP-Mikroskopie 70

2.9.4 Statistische Auswertung der Mikroskopiebilder 71

2.10 Proteinbiochemische Methoden ................................................................. 71

2.10.1 Die Herstellung von Zelllysaten ................................................................. 71

2.10.2 Co-Immunpräzipitation (Co-IP) zur Analyse von Protein-Protein und RNAProtein Interaktionen (RIP)

2.10.3 Zwei-Schritt-Affinitätsreinigung zur Analyse von RNA-ProteinInteraktionen

2.10.4 Affinitätsreinigung heterolog exprimierter Proteine.

2.10.5 Analyse von Ribosomenprofilen mittels Saccharose-DichtegradientenZentrifugation

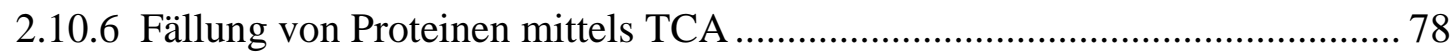

2.10.7 SDS-Polyacrylamid-Gelelektrophorese (SDS-PAGE) ................................ 78

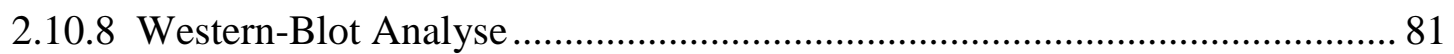

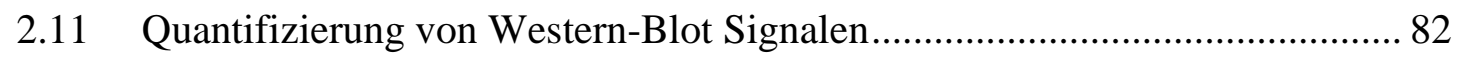

2.12 Vorbereitung für die Massenspektroskopischen Analysen ........................... 82

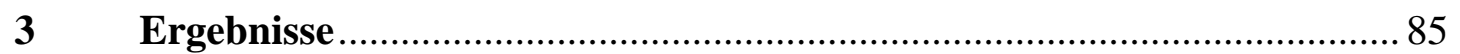

3.1 Bei verschiedenen Stressbedingungen dissoziieren die Adaptorproteine von der $\operatorname{poly}(\mathrm{A})^{+} \mathrm{RNA}$

3.2 Charaterisierung der Mex67-bindenden Adaptorproteine bei Stress

3.2.1 Co-Lokalisationsstudien der $\mathrm{SR}_{\mathrm{c}}$-Proteine bei Stress mit den zytoplasmatischen ,stress granules“ oder „P-bodies“

3.2.2 Die Adaptorproteine werden gemeinsam mit dem Exportrezeptor Mex67 von der regulären poly $(\mathrm{A})^{+} \mathrm{RNA}$ abgelöst

3.2.3 Posttranslationale Modifikationen von $\mathrm{Npl3} \mathrm{\ldots .............................................} 94$

3.3 Analyse der Stress-spezifischen Transkripte …............................................ 97

3.3.1 Expressionsnachweis der Stress-spezifischen mRNAs .............................. 97 
3.3.2 Mex67-Mtr2, aber nicht die Adaptorproteine sind für den Export der Stressspezifischen Transkripte verantwortlich

3.4 Untersuchungen von Mex67-Mtr2 unter Stressbedingungen 100

3.4.1 Mex67 bleibt unter Hitzestress an der nukleären Pore lokalisiert 100

3.4.2 Massenspektroskopische Analysen mit Mex67-GFP . 101

3.4.3 Herstellung eines $M S I I L$-Konstruktes zur Untersuchung von Proteinbindungen an Stress-spezifische mRNAs. 110

3.4.4 Analyse der interagierenden Proteine, die bei Hitzestress an die HSP12-2xMSIIL-mRNA binden

3.4.5 Mex67-Mtr2 bindet mRNAs in vitro 116

3.4.6 Mex67-Mtr2 exportiert die Stress-spezifischen Transkripte direkt 119

3.5 Mex67 ist bei Hitzestress mit dem Translationskomplex assoziiert. 122

3.6 Die Qualität der regulären mRNAs wird vor dem Transport kontrolliert, während die Stress-spezifischen Transkripte unkontrolliert in das Zytoplasma exportiert werden

3.7 Der Export der Stress-spezifischen mRNAs wird über den Promoter kontrolliert 130

4 Diskussion 136

4.1 Mechanismen der Dissoziation der Adaptorproteine im Zellkern von der $\operatorname{poly}(\mathrm{A})^{+} \mathrm{RNA}$ 136

4.2 Die SR-Proteine in ,stress granules“ und „P-bodies“ 139

4.3 Qualitätskontrolle des mRNA-Exportes .................................................... 140

4.4 Der direkte Mex67-vermittelte Export von Hitzestress-mRNAs................... 142

4.4.1 Interaktionspartner von Mex67 bei Hitze- oder Salzstress ........................... 142

4.4.2 Proteine, die mit der Hitzestress-mRNA HSP12 interagieren ..................... 144

4.4.3 Mex67-Mtr2 bindet direkt an Hitzestress-mRNAs .................................... 145

4.5 Mex67 wird bei Hitzestress nicht durch Dbp5 von Hitzestress-mRNAs dissoziiiert

4.6 Der Promotor bestimmt, ob mRNAs qualitätskontrolliert werden ..... 147 
Inhaltsverzeichnis

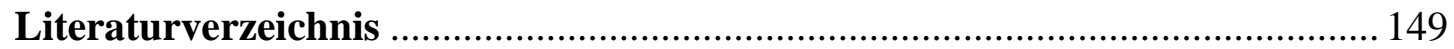

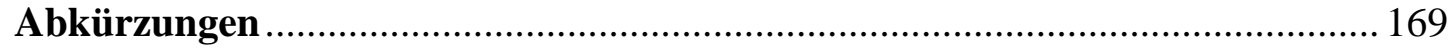

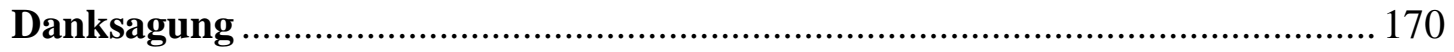

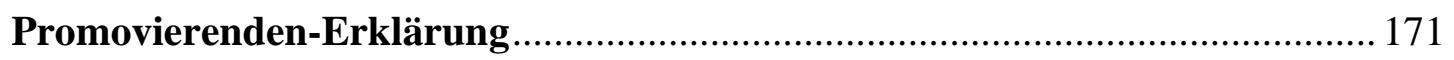




\section{Abbildungsverzeichnis}

Abbildung 1: Die verschiedenen Phosphorylierungen der C-terminalen Domäne (CTD) der RNA-Pol II während der Transkription. 9

Abbildung 2: Schematische Darstellung des mRNA-Exports...................................11

Abbildung 3: Schematische Darstellung des Kernporenkomplexes (NPCs)...............14

Abbildung 4: Schematische Darstellung des heterodimeren mRNA-Exportrezeptors

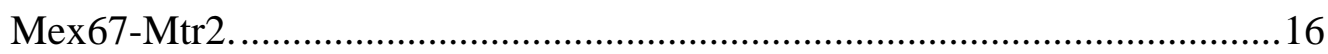

Abbildung 5: Die Domänenabfolge der SR-Proteine............................................. 18

Abbildung 6: Die Domänenabfolge von Nab2 ....................................................21

Abbildung 7: Die mRNA-Qualitätskontrolle im Zellkern.........................................23

Abbildung 8: Die mRNA-Qualitätskontrolle am Kernporenkomplex. ......................26

Abbildung 9: Regulationsmechanismen der Transkriptionsfaktoren Msn2/4 und Hsf1.

Abbildung 10: Der Aufbau und der Regulierungsmechanismus von Hsf1.

Abbildung 11: Der mRNA-Export bei zellulärem Stress. 32

Abbildung 12: Die zytoplasmatische RNA-Biologie bei Stressbedingungen. 35

Abbildung 13: Die mRNA-Bindeproteine und Mex67 weisen verringerte poly $(\mathrm{A})^{+}$RNA Bindung bei Stress auf.

Abbildung 14: Das Mex67-bindende Adaptorprotein Gbp2 dissoziiert bei Stress von der $\operatorname{poly}(\mathrm{A})^{+} \mathrm{RNA}$.

Abbildung 15: Die mRNA-Bindeproteine und Mex67 binden signifikant geringer an poly $(\mathrm{A})^{+}$RNA während Hitze- oder Salzstress.

Abbildung 16: Die zytoplasmatischen Versionen der SR-Proteine zeigen eine freie und RNA-ungebundene Diffusion in der Zelle bei Stress.

Abbildung 17: Die $\mathrm{SR}_{\mathrm{c}}$-Proteine co-lokalisieren mit den Proteinmarkern für „stress granules“ und teilweise für „P-bodies“.

Abbildung 18: Npl3 und Nab2 interagieren in vivo physikalisch mit Mex67 und diese Protein-Interaktion ist RNA- und Stress-unabhängig. .93

Abbildung 19: Npl3 wird an verschiedenen Aminosäureresten phosphoryliert. .95

Abbildung 20: Die Stress-spezifischen Transkripte HSP12 und SSA4 werden spezifisch bei Hitze- und Salzstress exprimiert. 
Abbildung 21: Der heterodimere mRNA-Exportrezeptor Mex67-Mtr2, aber nicht seine Adaptorproteine, wird für den Transport von den Stress-spezifischen Transkripten SSA4 und HSP12 benötigt. 99

Abbildung 22: Mex67 und Dbp5 bleiben bei Hitzestress am NPC lokalisiert.........100

Abbildung 23: Mex67-GFP und dessen interagierende Proteine. 102

Abbildung 24: Wachstums-, Lokalisations- und Interaktionsstudien mit Dbp3......106

Abbildung 25: Yra2 hat keinen Einfluss auf die Stressantwort bei Hefezellen. 109

Abbildung 26: Die HSP12-2xMSIIL-mRNA wird synthetisiert und ist korrekt lokalisiert.

Abbildung 27: Proteine, die mit der HSP12-2xMSIIL-mRNA interagieren. 113

Abbildung 28: Mex67-Mtr2 kann in vitro mRNAs binden. 117

Abbildung 29: Mex67 benötigt seine ,loop“-Domäne für die RNA-Bindung. 118

Abbildung 30:Die ,loop“-Domäne von Mex67-Mtr2 ist wichtig für den Export von der Hitzestress-mRNA SSA4......

Abbildung 31: Mutanten von MEX67 und MTR2 zeigen Exportdefekte der HSP12mRNA bei Hitzestress.

Abbildung 32: Mex67 bleibt bei Hitzestress an die aktiv translatierenden Polysomen gebunden

Abbildung 33: Durch die selektive Zerstörung der Polysomen ist Mex67 nach Hitzestress nicht mehr Ribosomen-gebunden. 125

Abbildung 34: Bei Hitzestress bleibt Mex67 an die Stress-spezifischen Transkripte gebunden und ist daher in Polysomen zu detektieren. 126

Abbildung 35: Der Export der SSA4-mRNA und der HSP12-mRNA ist in den Mutanten des TRAMP-Komplexes oder des nukleären Exosoms nicht beeinträchtigt

Abbildung 36: Die Stress-spezifischen Transkripte SSA4 und HSP12 werden unabhängig von der Dauer des Hitzestresses und unabhängig von Mtr4 und Rrp6 ins Zytoplasma exportiert.

Abbildung 37: Das reguläre CYC1-GFP-Transkript wird unter Kontrolle des HSP12Promotors bei Hitzestress in das Zytoplasma exportiert.

Abbildung 38: Das $P_{H S P 12}-C Y C 1-G F P$-Transkript wird bei Hitzestress wie eine Stress mRNA exportiert, während die poly $(\mathrm{A})^{+} \mathrm{RNA}$ im Zellkern akkumuliert. .....132

Abbildung 39: Modell für den Export der mRNAs bei Stress.. 135 


\section{Tabellenverzeichnis}

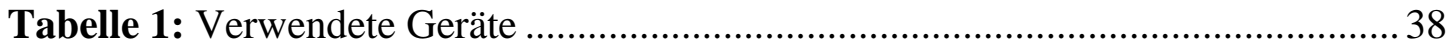

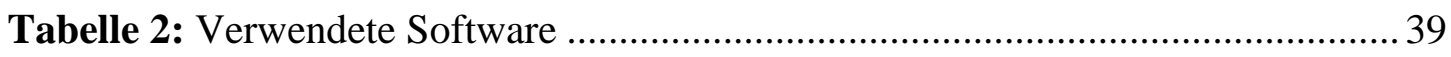

Tabelle 3: Allgemeine Chemikalien und Verbrauchsmaterialen............................... 40

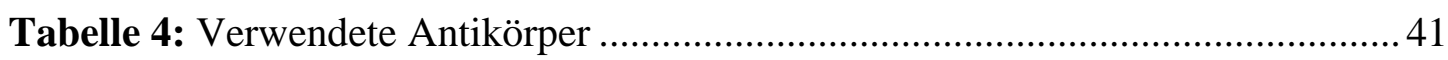

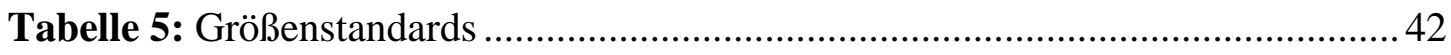

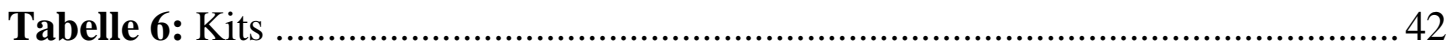

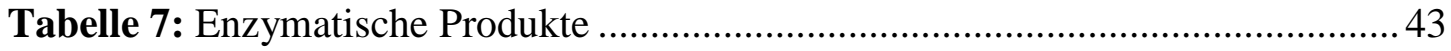

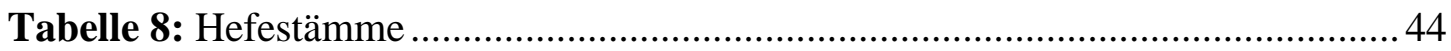

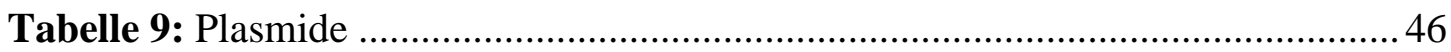

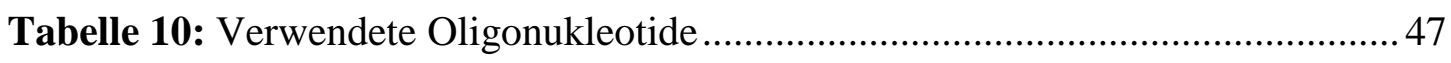

Tabelle 11: Standardreaktion für die "Dream Taq" DNA Polymerase. ......................54

Tabelle 12: PCR-Programm für die "Dream Taq" DNA Polymerase.........................54

Tabelle 13: Lösungen für die Probenvorbereitung zur Messung mittels der MS....... 84

Tabelle 14: Mex67-GFP interagierende Proteine ................................................... 103

Tabelle 15: Proteine, die mit der HSP12-2xMSIIL-mRNA unter Hitzestress interagieren 


\section{Zusammenfassung}

Um eine zelluläre Stresssituation überleben $\mathrm{zu}$ können, exprimieren Zellen Chaperonproteine, die missgefaltete Proteine stabilisieren und so das Überleben sichern. Um die sofortige Expression von Stress-spezifischen Genen sicherzustellen, wird die Transkription von regulären mRNAs und deren Export inhibiert, während die Stressspezifischen mRNAs selektiv exportiert und translatiert werden.

Diese Arbeit untersucht, warum reguläre Transkripte im Zellkern akkumulieren und gibt einen Einblick in den selektiven Transportmechanismus der Stress-spezifischen mRNAs in Saccharomyces cerevisiae. Mittels RNA-Co-Immunpräzipitationsexperimenten konnte gezeigt werden, dass die mRNA nicht mehr exportiert wird, da der mRNA-Exportrezeptor Mex67-Mtr2 sowie seine Adaptorproteine Npl3, Gbp2, Hrb1 und Nab2 von der mRNA dissoziiert

In dieser Arbeit wurde weiterhin untersucht, wie die Stress-spezifischen Transkripte exportiert werden. Dazu wurden Fluoreszenz in situ Hybridisierungsexperimente (FISH) mit spezifischen Sonden gegen Stress-spezifische mRNAs in verschiedenen Exportmutanten durchgeführt. Die Ergebnisse zeigen, dass nur der heterodimere Exportrezeptor Mex67Mtr2, aber keines der bisher bekannten Mex67-bindenden Adaptorproteine Npl3, Gbp2, Hrb1 und Nab2 für den Export von Stress-spezifischen mRNAs notwendig ist. In vitro RNABindestudien weisen darauf hin, dass Mex67-Mtr2 direkt an reguläre und Stress-spezifische Transkripte ohne Adaptorproteine binden kann. Für die Bindung ist eine „loop“-ähnliche Struktur innerhalb des Heterodimers notwendig. Mittels Dichtegradienten-Zentrifugationsexperimenten konnte nachgewiesen werden, dass das direkt gebundene Mex67 an die exportierten Stress-spezifischen mRNAs im Zytoplasma bis zur Translation assoziiert bleibt, also nicht wie beim regulären mRNA Transport von der RNA-Helikase Dbp5 nach der Translokation durch den Kernporenkomplex dissoziiert wird.

Die Frage, warum die mRNA-Adaptorproteine auf reguläre mRNAs geladen werden, wenn sie für die Bindung des Exportrezeptor an die mRNA eigentlich nicht erforderlich sind, könnte durch die Funktion der Adaptorproteine als mRNA-Qualitätskontrollproteine erklärt werden. Die mRNA-Adaptoren scheinen eine frühzeitige Bindung des mRNAExportrezeptors an die mRNA zu verhindern. Doch bei Stress könnte diese mRNAQualitätskontrolle umgangen werden und Mex67-Mtr2 wird anstelle dessen direkt auf die Stress-spezifischen mRNAs geladen. 
Weitere Hinweise, dass die mRNA-Qualitätskontrolle während Stress nicht verwendet wird, zeigen FISH-Experimente mit Sonden gegen Stress-spezifische Transkripte in Mutanten der mRNA-Qualitätskontrolle und des nukleären Exosoms (mtr4-G677D und rrp64). Es findet keine Blockade der nicht-prozessierten Stress-spezifischen Transkripte im Zellkern statt, während nicht-korrekte reguläre Transkripte unter normalen Wachstumsbedingungen im Zellkern in diesen Mutanten akkumulieren. Somit kann die Stress-spezifische mRNA vermutlich auf Kosten einer stets korrekten Prozessierung schneller in das Zytoplasma exportiert und umgehend translatiert werden.

Welche Exportweg eingeschlagen wird, der qualitätskontrollierte oder der unkontrollierte könnte im Promotor der Gene codiert sein, da in dieser Studie durch FISH-Experimente gezeigt werden konnte, dass eine reguläre mRNA (CYCl) unter der Kontrolle des Hitzeschockpromotors des HSP12 Genes ebenfalls während Hitzestress schnell und unkontrolliert in das Zytoplasma exportiert wird. 


\section{Summary}

In response to stress cells activate a prompt expression of stress-specific genes of which chaperones are essential in stabilizing and refolding proteins. In this situation stress-specific RNAs are selectively transcribed, exported and translated while these processes for regular mRNAs are repressed. The aim of this study was to investigate the mechanisms that suppresses regular mRNA export from the nucleus to the cytoplasm during stress and allow selective transport of stress specific mRNAs.

RNA-co-immunoprecipitation (RIP) experiments revealed that binding of the general mRNA adapter proteins Npl3, Gbp2, Hrb1 and Nab2 and the export receptor Mex67-Mtr2 for poly $(\mathrm{A})^{+} \mathrm{RNA}$ is strongly reduced in Saccharomyces cerevisiae under cellular stress which consequently leads to a loss of transport competence and prevents nuclear export. Nuclear export of stress specific mRNAs (SSA4 and HSP12) was analyzed by RNA fluorescence in situ hybridization (RNA-FISH) experiments in mutant strains of the mRNA export factors. In contrast to regular mRNA stress specific RNAs are bound by the export receptor Mex67-Mtr2 but not by the adapter proteins (Npl3, Gbp2, Hrb1 and Nab2) indicating the sufficiency of Mex67-Mtr2 for export competence. This was further proved via direct binding of Mex67-Mtr2 to regular and stress specific transcripts without the need of adapter proteins shown by in vitro RNA-binding studies. Interestingly the binding of Mex67 to mRNA is established by its loop-domain. In contrast to exported regular mRNAs Mex67 remains bound on cytoplasmic stress-specific transcripts during heat shock as Mex67 co-precipitates with polysomes shown by sucrose density centrifugation experiments.

Based on the difference between the mRNA export modes (normal condition and stress) the question arises why binding of the adapter proteins to regular mRNA is useful, taking into account that the export receptor Mex67-Mtr2 can bind directly. A possible explanation might be a function of the mRNA adapter proteins in the quality control of regular mRNAs while stress specific transcripts undergo no control before nuclear export. Within the quality control process the adapter proteins prevent presumably an early binding of the mRNA export receptor to the mRNA. This study could show that unprocessed stress specific transcripts are not accumulated in mRNA quality control mutants indicating the fast export of stress specific mRNAs without the need for the quality control mechanism. This was analyzed by FISH experiments. 
Furthermore this study demonstrates that the promoter region within the RNA determines whether a transcript undergoes quality control or not. This was supported by converting the regular mRNA into a stress-responsive transcript by fusing the open reading frame of $C Y C 1$ with the heat shock promoter HSP12.

In summary RNA adapter proteins play a role in mRNA surveillance under normal conditions and prevent an early association of the export receptor Mex67-Mtr2. However, during stress, quality control is bypassed and Mex67 could be instead directly recruited to heat-responsive genes and loaded onto the stress-specific transcripts for instant nuclear export. 


\section{Einleitung}

\subsection{Der Transport der mRNA}

\subsubsection{Die mRNA-Synthese}

Ein Kennzeichen eukaryotischer Zellen ist ihre Kompartimentierung, wodurch die mRNASynthese und ihre Prozessierung im Zellkern von der Translation in Proteine im Zytoplasma separiert werden (Bonnet und Palancade, 2014). Diese räumliche Trennung von Transkription und Translation ermöglicht eine komplexe Regulation der Genexpression, die zur eukaryotischen Funktionenvielfalt beiträgt.

Die Transkription der Gene in mRNAs (,messenger" RNAs) wird in Eukaryoten von der RNA-Polymerase II (RNA-Pol II) durchgeführt (Bataille et al., 2012). Dieser große Enzymkomplex ist von der Hefe zum Menschen hoch konserviert. Rbp1 ist die größte Untereinheit der RNA-Pol II und enthält eine C-terminale Domäne (CTD), die eine konservierte Heptapeptid-Sequenzwiederholung beinhaltet: $\mathrm{Y}_{1} \mathrm{~S}_{2} \mathrm{P}_{3} \mathrm{~T}_{4} \mathrm{~S}_{5} \mathrm{P}_{6} \mathrm{~S}_{7}$ (Chapman et al., 2008). In Hefe wird diese Sequenz 26-mal wiederholt, während in Säugetieren diese Abfolge bis zu 52-mal wiederholt werden kann (Bataille et al., 2012). Während der Transkription wird die CTD von Rpb1 in S. cereviaise zu verschiedenen Zeitpunkten modifiziert (Abbildung 1b). Dadurch kann eine zeitliche Rekrutierung von mRNA-Prozessierungsfaktoren wie der 5'Kappen-Bindekomplex, die Spleißingfaktoren, die 3'-Prozessierungs-, Polyadenylierungsund Exportfaktoren koordiniert werden (Heidemann et al., 2013). Während die RNA-Pol II mit der Promotoregion des zu transkribierenden Genes interagiert, liegt die CTD noch unphosphoryliert vor und bildet den Prä-Initiationskomplex (Bataille et al., 2012) (Abbildung 1b).

Zusätzlich wurde in Abbildung 1a ein Gen grafisch dargestellt und in folgende Bereiche eingeteilt: Neben dem Promotor wurden die „5 prime untranslated region“ (5'-UTR), der „open reading frame“ (ORF) und die ,3 prime untranslated region“ (3‘-UTR) skizziert. Zusätzlich wird die Polyadenylierungsstelle (pA) und die 3'-Prozessierung der mRNA angezeigt. 
a

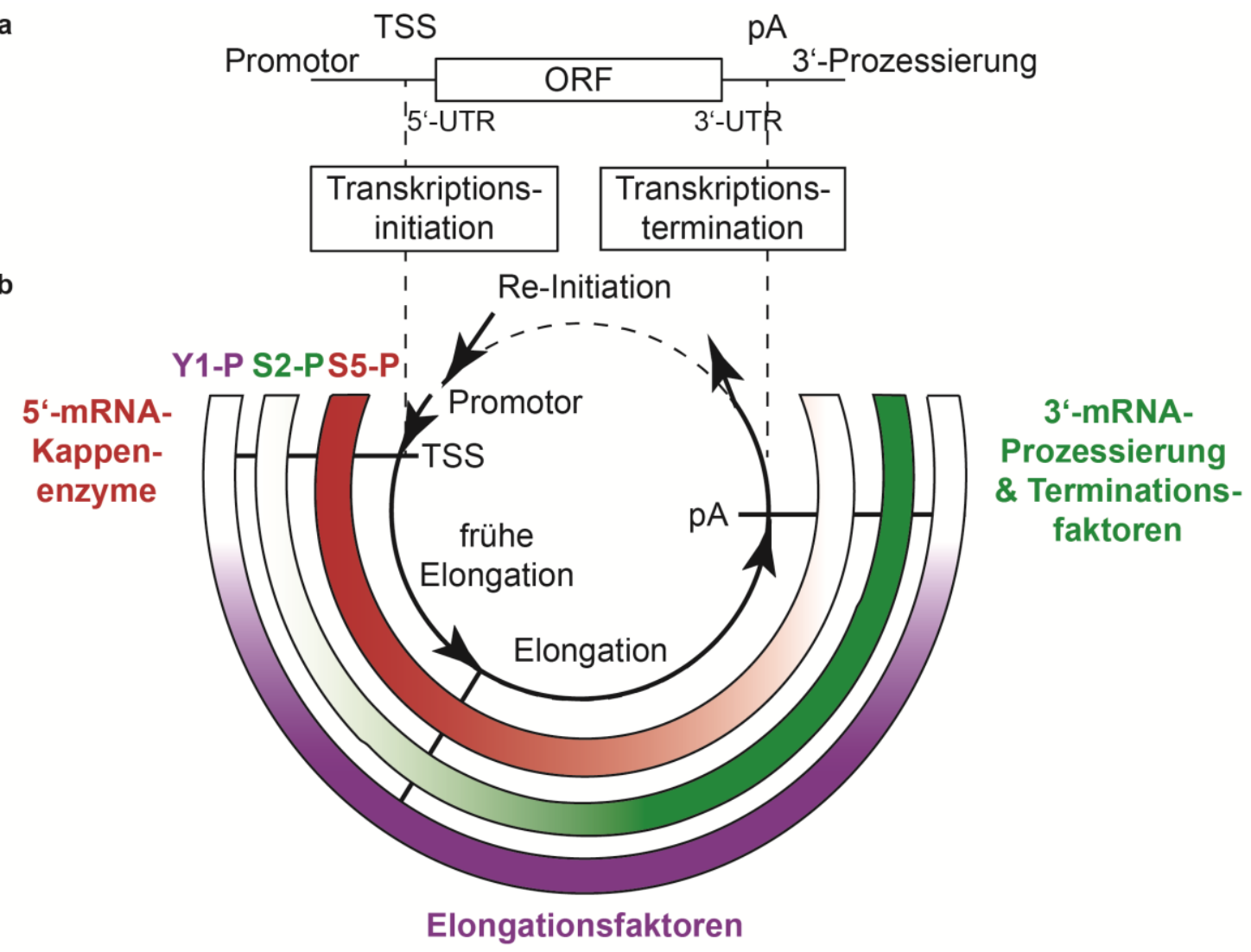

b

Abbildung 1: Die verschiedenen Phosphorylierungen der C-terminalen Domäne (CTD) der RNA-Pol II während der Transkription. a, Schematische Darstellung eines Genes mit Promotor, 5'-UTR, ORF und 3'UTR. Die gestrichelten Linien markieren den Transkriptionsstartpunkt (TSS) und die Polyadenylierungssequenz (pA). b, Das Phosphorylierungsmuster der CTD ändert sich während der Transkription, die Ser5 Phosphorylierung (in rot) erfolgt bei der Initiation. Während der Elongation bis hin zur Termination findet die Phosphorylierung des Ser2-P (in grün) statt. Zusätzlich befindet sich Tyr1-P (in violett) vorwiegend während der Elongation im phosphorylierten Zustand (Modell modifiziert nach Mayer et al., 2012).

Nach der Synthese der ersten 20 bis 30 Nukleotide der prä-mRNA, findet die Phosphorylierung des Aminosäurerestes Serin-5 der CTD statt und führt zur Rekrutierung der 5'-RNA-Kappen-Enyzme, die bereits die co-transkriptionale Prozessierung der 5'-prä-mRNA veranlassen (Lidschreiber et al., 2013). Durch den Cet1-Ceg1-Komplex wird das 5'-Triphosphat-Ende der prä-mRNA mit einer 7-Methylguanosin-Kappe versehen, welche wiederum vom „cap binding complex“ (CBC) erkannt und gebunden wird. Der CBC beinhaltet die Proteine Cbp20 und Cbp80. Die Kappenstruktur schützt die prä-mRNA vor dem Abbau durch die 5'-3' Exonukleasen (Rat1 oder Xrn1) und stimuliert den Aufbau des Spleißosoms (Görnemann et al., 2005). Der CBC-Komplex interagiert mit dem pendelnden Serin/Arginin (SR)-reichen RNA-Bindeprotein Npl3, welches co-transkriptional auf die prämRNA geladen wird (Shen et al., 2000). Npl3 interagiert mit der CTD nach Phosphorylierung am Serinrest-2 während der Transkriptionselongation (Baejen et al., 2014; Dermody et al., 2008). Außerdem wird durch die Bindung von Npl3 an das entstehende 
Transkript die Transkriptionstermination inhibiert, indem es mit dem Faktor CF1A und dem Polyadenylierungskomplex um Adenosin-reiche Sequenzen konkurriert (Bucheli und Buratowski, 2005). Dieser Mechanismus verhindert die vorzeitige Transkriptionstermination an kryptischen Terminationsstellen und stellt eine Auto-Regulation von Npl3 selbst dar, da das eigene Gen eine schwache Adenosin-reiche Sequenz besitzt.

Im weiteren Verlauf der Transkription rekrutiert die RNA-Pol II den THO-Komplex an die DNA und prä-mRNA (Abbildung 2). Der Komplex bildet sich aus dem namensgebenden Protein Tho2 sowie den Komponenten Hpr1, Mft1 Thp2 und Tex1 und unterstützt den reibungslosen Ablauf der Transkription durch die Unterbindung von DNA-RNAHybridformationen während der Transkriptionselongation (Huertas und Aguilera, 2003; Rondón et al., 2003). Es wurde gezeigt, dass eine HRP1 Deletion zu DNA-RNA-Hybriden $\left(, R\right.$-loops $\left.{ }^{6}\right)$, Hyperrekombination und genomischer Instabilität führt (Huertas und Aguilera, 2003). Die Deletion des MFTl Genes fördert die Akkumulation von prä-mRNAs im Zellkern und verhindert das Ablösen des Transkriptionskomplexes vom Chromatin. Somit bilden sich große Aggregate in der Zelle, die als ,heavy chromatin“ bezeichnet werden (Rougemaille et al., 2007). Tex1 wurde als Kernkomponente des THO-Komplex beschrieben, auch wenn die Deletion des Genes keinen erkennbaren Phänotyp zeigt (Gewartowski et al., 2012). Der THO-Komplex vermittelt die Rekrutierung von verschiedenen RNA-Bindeproteinen an die mRNA, die am Export der ,messenger ribonucleoprotein particles“ (mRNPs) beteiligt sind. Dazu gehören die zwei Serin/Arginin (SR)-reichen Proteine Hrb1 und Gbp2 (Hacker und Krebber, 2004; Windgassen und Krebber, 2003). Sie werden co-transkriptional durch den THO-Komplex auf die prä-mRNA geladen (Abbildung 2) und kontrollieren die korrekte Prozessierung der prä-mRNA (Hurt et al., 2004). Desweiteren interagieren Gbp2 und Hrb1 mit den mRNA-Qualitätskontrollfaktoren des $\underline{\operatorname{Tr}} 4$ - $\underline{A}$ ir-Mtr4-Polyadenylierungskomplexes (TRAMP-Komplexes) zur Eliminierung nicht korrekt prozessierter oder ungespleißter prä-mRNAs. Durch Oligoadenylierung am 3‘-Ende wird die prä-mRNA dann für den Abbau markiert. Anschließend wird die markierte mRNA durch Bindung des nukleären Exosoms abgebaut. Bei korrekter Prozessierung der mRNAs intergieren Gbp2 und Hrb1 direkt mit dem mRNAExportrezeptor Mex67-Mtr2 und unterstützen den Export der mRNA aus dem Zellkern in das Zytoplasma (Hackmann et al., 2014). 
Weitere Faktoren, die durch den THO-Komplex an die entstehende mRNA rekrutiert werden, sind Yra1 und Sub2. Gemeinsam bilden sie den TRanskriptions-EXport (TREX-1)Komplex (Abbildung 2). Die Interaktion von Sub2 mit dem THO-Komplex und der mRNA führt zur Bindung von Yral an die prä-mRNA (Jensen et al., 2001; Jimeno et al., 2002; Strässer und Hurt, 2001). Yra1 und das ubiquitinylierte Hpr1 des TREX-1-Komplexes laden den Exportrezeptor Mex67-Mtr2 auf die mRNA (Babour et al., 2012; Katahira, 2011). Dabei kann Yra1 nur mit Mex67 interagieren, wenn Sub2 von Yra1 dissoziiert und durch Mex67 ersetzt wird (Reed und Hurt, 2002; Strässer und Hurt, 2001).

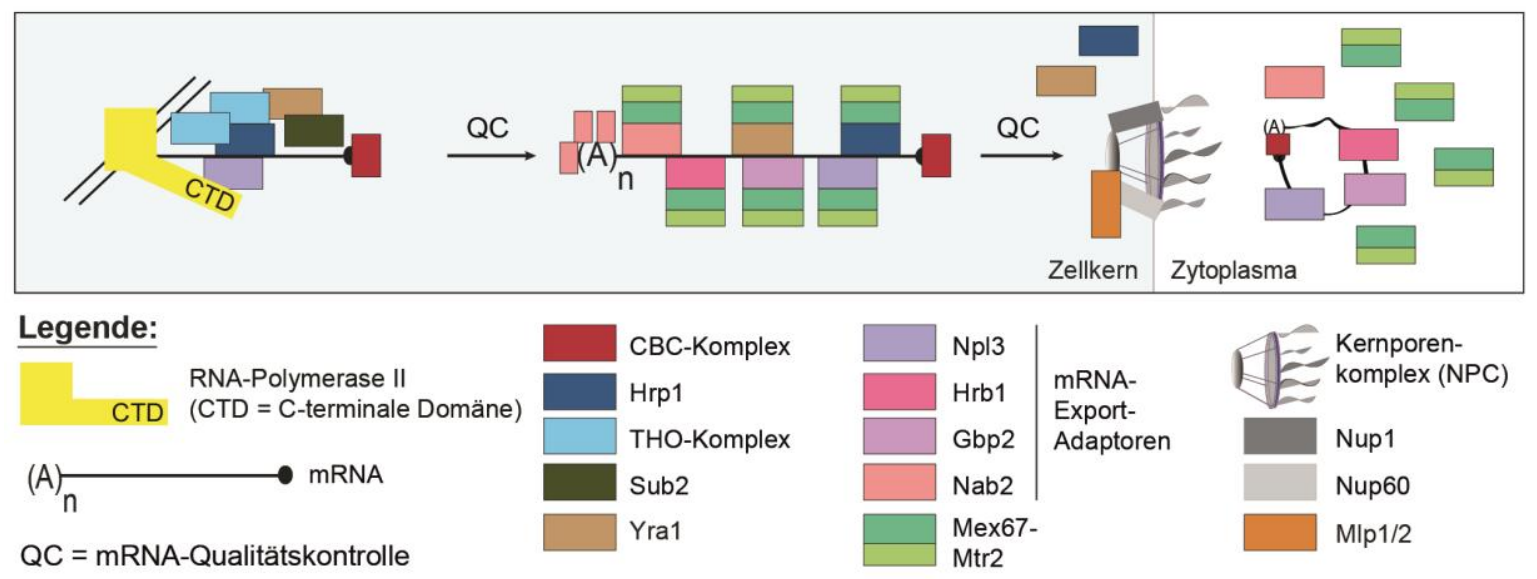

Abbildung 2: Schematische Darstellung des mRNA-Exports. Noch während der Transkription assoziieren der CBC, Npl3 und die mRNA-bindenden Faktoren des THO-Komplexes an die prä-mRNA. Yra1, Hrp1, Gbp2, Hrb1, Npl3 und Nab2 rekrutieren den Export-Rezeptor Mex67-Mtr2, der die Translokation der mRNA durch die Zellkernporen vermittelt. Des Weiteren interagieren Np13, Gbp2, Hrb1 und Nab2 mit Mlp1, einem Kernporenkomplex assoziierten Faktor, der eine Funktion in der finalen mRNA-Qualitätskontrolle hat.

Durch einen genetischen „screen“ mit einer yral-Mutante wurde der Transkriptions- und Export-Komplex TREX-2 identifiziert (Fischer et al., 2002). Dieser Komplex besteht aus den fünf Untereinheiten Sac3, Thp1, Sus1, Cdc31 und Sem1 und lokalisiert an die nukleoplasmatische Seite des „nuclear pore complexes“ (NPCs) (Faza et al., 2009; Fischer et al., 2004; Wilmes et al., 2008). Sac3 dient dem TREX-2-Komplex dabei als Strukturprotein und organisiert mit seiner N-terminalen Domäne die Interaktion von Thp1 und Sem1. Zusätzlich bindet sie an Mex67 und bildet somit einen Komplex mit Thp1 und Sem1, der für die RNA-Bindung und die Exportfunktion verantwortlich ist (Ellisdon et al., 2012). Die C-terminale Domäne von Sac3 formt eine lange $\alpha$-helikale Struktur und ist für die Rekrutierung von Sus1 und Cdc31 wichtig (Jani et al., 2009). Weiterhin verankert er mit dem NPC und bringt auf diese Weise die mRNA in räumliche Nähe zum Kernporenkomplex

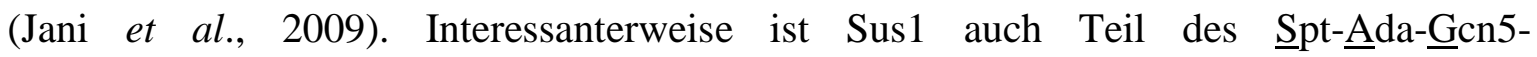
Acetyltransferase (SAGA)-Komplexes und damit an der Modifikation von Histonproteinen 
und an der Transkriptionsaktivierung beteiligt (Köhler et al., 2008). Das deutet daraufhin, dass der TREX-2-Komplex an der Koordination und am Export der mRNAs beteiligt ist (Rodríguez-Navarro et al., 2004). Als weitere Funktion schützt der TREX-2-Komplex ähnlich wie der THO/TREX-Komplex vor Transkriptions-abhängiger HyperRekombination und schützt ebenfalls vor genomischer Instabilität (González-Aguilera et al., 2008).

In weiteren Prozessierungsschritten der prä-mRNA werden Intron-haltige Transkripte in der Hefe co-transkriptional gespleißt (Will und Lührmann, 2011). In S. cerevisiae besitzen zwar nur $5 \%$ aller Gene ein Intron (ca. 250 Gene), dennoch machen diese Gene 1/3 des gesamten zellulären Transkriptoms aus, da sie hoch exprimiert sind (Niño et al., 2013). Vorwiegend handelt es sich dabei um ribosomal codierende Transkripte, wobei 102 von 139 prä-mRNAs ein Intron enthalten (Davis et al., 2000; Spingola et al., 1999). Die mRNA-Spleißreaktion erfolgt über eine Phosphoester-Transferreaktion und wird von dem Spleißosom durchgeführt. Das Spleißosom setzt sich aus über 80 Proteinen und fünf snRNAs (,small nuclear RNAs“) (U1, U2 U4, U6 und U5) zusammen (Jurica and Moore, 2003). Viele dieser Bausteine sind in stabilen Subkomplexen organisiert und lagern sich aus spleißosomalen Proteinen und den snRNAs zu RNA-Proteinpartikeln, den snRNPs (,small nuclear ribonucleoprotein particles" ${ }^{6}$ ), zusammen (Wahl et al., 2009).

Nach Ausbildung der Kappenstruktur und dem Spleißen intronhaltiger Transkripte findet die 3'-Prozessierung und Polyadenylierung statt (Ahn et al., 2004; Barillà et al., 2001). Für die Rekrutierung der Faktoren, die für die 3'-Prozessierung und Polyadenylierung notwendig sind, ist eine Ctk1-abhängige Phosphorylierung des Serinrestes-2 der CTD notwendig (Abbildung 1b) (Ahn et al., 2004). Die Transkription der Polyadenylierungssequenz initiiert die finale prä-mRNA-Prozessierung und wird durch die 3'-Prozessierungsmaschinerie erkannt. Als Teil des „cleavage und Polyadenylierungsfaktor“ (CPF)-Komplexes bindet Rna14 an eine AU-reiche Sequenz und positioniert den CPF-Komplex an der poly(A)Position. Außerdem wird die AU-reiche Sequenz von Hrp1 gebunden, um die „cleavage“Reaktion zu unterstützen (Barnwal et al., 2012; Kessler et al., 1997). Zu dem CPF-Komplex gehören, Hrp1, der „cleavage factor 1A“ (CF1A) und das Heterodimer Rna14-Rna15 (González et al., 2000). Nach dem Schneiden der Polyadenylierungssequenz synthetisiert die polyA-Polymerase Pap1 am 3'-Ende der mRNA einen 70 bis 90 Nukleotid langen poly(A)-Schwanz, dessen Länge von den beiden poly(A)+bindenden Proteinen Nab2 und 
Pab1 kontrolliert wird (Dunn et al., 2005; Hector et al., 2002). Dieser finale Polyadenylierungsschritt führt zum Ablösen des Prozessierungs-komplexes, was wiederum bewirkt, dass das exportkompetente mRNP vom Transkriptionsapparat abgelöst wird (Hilleren et al., 2001; Libri et al., 2002; Qu et al., 2009).

Exportkompetent werden die mRNPs durch die Bindung von Mex67-Mtr2 an die pendelnden Adaptorproteine Npl3, Hrb1, Gbp2 und Nab2, die an unterschiedlichen Stellen an die mRNA gebunden vorliegen (Batisse et al., 2009; Hackmann et al., 2014). Die Bindung der mRNA-Adaptoren mit dem Exportrezeptor können durch posttranslationale Modifikationen beeinflusst werden. So wird z. B. Npl3 phosphoryliert, damit eine zeitliche Verschiebung der Bindung an Mex67 passieren kann, da dephosphoryliertes Np13 eine höhere Bindungsaffinität zu Mex67 besitzt (Gilbert und Guthrie, 2004).

\subsubsection{Die mRNPs werden vom Zellkern durch den Kernporenkomplex in das Zytoplasma transportiert}

Der NPC ist für den Austausch von Molekülen zwischen Zellkern und Zytoplasma verantwortlich (Bonnet und Palancade, 2014). Dieser Komplex ist ein Multiproteingefüge, das aus mehreren Kopien von mindestens 30 verschiedenen Nukleoporinen (Nups) besteht und eine molekulare Masse von $60 \mathrm{MDa}$ in Hefe besitzt (Floch et al., 2014). Die komplexe NPC Struktur ist von der Hefe bis zum Menschen hoch konserviert und achtfach symmetrisch aufgebaut. Sie wird in der Kernmembran verankert und besitzt einen zentralen Tunnel mit einem Durchmesser von ca. 40 nm. Im Zellkern ist der Komplex korbähnlich aufgebaut und im Zytoplasma besitzt der Kernporenkomplex Filamente (Abbildung 3) (Köhler und Hurt, 2007). 


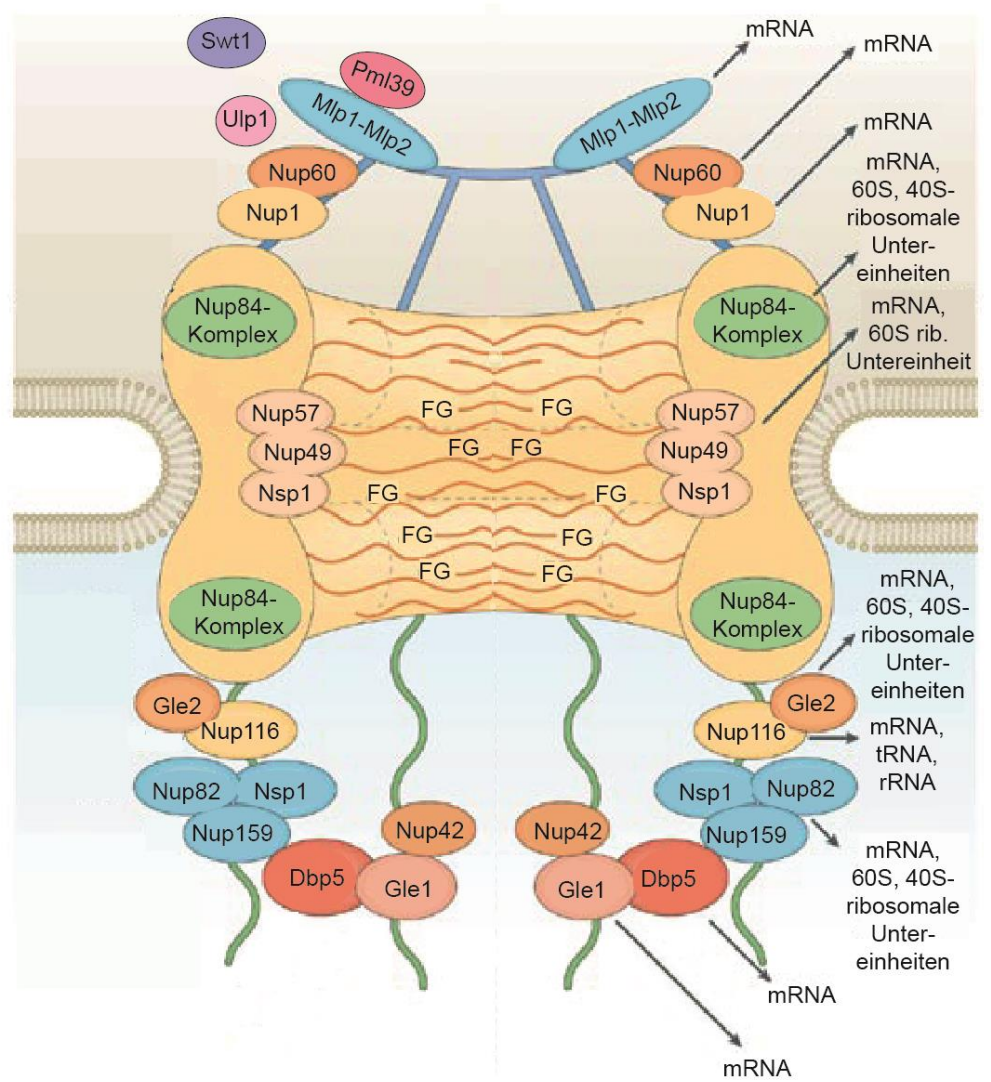

Abbildung 3: Schematische Darstellung des Kernporenkomplexes (NPCs). Es sind Nukleoporine und assoziierte Proteine dargestellt, die den mRNA Export am NPC beeinflussen. Die meisten Nukleoporine sind symmetrisch an beiden Seiten des NPCs angeordnet, doch einige Proteine findet man ausschließlich auf der nukleären oder nur auf der zytoplasmatischen Seite des NPCs. FG, Phenylalanin/Glycin-DipeptidSequenzwiederholungen. Das Modell wurde modifiziert nach (Köhler und Hurt, 2007).

Das Netzwerk des NPCs lässt passive Diffusion von kleinen Molekülen zu und ermöglicht einen gerichteten Transport von großen Molekülkomplexen (wie z. B. Proteinen oder mRNPs) mit nukleären Signalsequenzen (,nuclear localization signal“ - NLS oder „,nuclear export signal“ - NES). Diese Sequenzen werden durch Transportrezeptoren (Karyopherine) erkannt, die wiederum dynamisch mit den Phenylalanin/Glycin (FG)-DipeptidSequenzwiederholungen der Nukleoporine interagieren (Floch et al., 2014; Wente und Rout, 2010). Die hydrophoben (FG)-Dipeptid-Sequenzwiederholungen werden durch hydrophile Linker separiert und so entsteht ein Netzwerk, was einen gerichteten Transport zulässt (Abbildung 3) (Terry und Wente, 2009). Durch die konservierte Interaktion der FGNukleoporine (FG-Nups) mit dem mRNA-Exportrezeptor Mex67-Mtr2 werden die Exportkompetenten mRNPs an den NPC rekrutiert und exportiert (Strässer et al., 2000; Strawn et al., 2001; Terry und Wente, 2007). An der nukleoplasmatischen Seite des NPCs tragen weitere Proteine, wie z. B. Mlp1/2, Ulp1 oder Pml39, zur Assoziation des mRNPs an 
den NPC bei (Abbildung 3). Mlp1 interagiert mit den mRNA-Adaptorproteinen Nab2, Npl3, Gbp2 und Hrb1 und kontrolliert dadurch die Export-kompetenten mRNPs am NPC (Green et al., 2003; Hackmann et al., 2014; Vinciguerra et al., 2005). Der finale Exportschritt der mRNPs durch den NPC wird als Translokation bezeichnet und benötigt die gerichtete Freisetzung des Komplexes im Zytoplasma (Carmody und Wente, 2009). Die Direktionalität des Transportes und die irreversible Freisetzung der mRNPs an der zytoplasmatischen Seite des NPCs wird durch die Funktion von zwei konservierten mRNA-Exportfaktoren bestimmt, Dbp5 und Gle1 (Alcázar-Román et al., 2006; Weirich et al., 2006). Dbp5/Rat8 ist eine RNAabhängige ATPase der DEAD-Box Proteinfamilie und bindet an der zytoplasmatischen Seite des NPCs durch die Interaktion mit Nup159/Rat7 (Schmitt et al., 1999; Snay-Hodge et al., 1998; Tseng et al., 1998) (Abbildung 3). Gle1 bindet speziell an das ,inositol hexakisphosphate" ( $\left.\mathrm{IP}_{6}\right)$ und ist mit dem Nukleoporin Nup42 am NPC verankert (AlcázarRomán et al., 2006; Kendirgi et al., 2005; Murphy et al., 1996; Strahm et al., 1999). Sobald das exportierte mRNP die zytoplasmatische Seite des NPCs erreicht, assoziiert es mit Dbp5 und dem IP $_{6}$-gebundenen Gle1 (Abbildung 3). Gle1 stimuliert die ATPase-Aktivität von Dbp5, dabei findet eine Nukleotid-abhängige Konformationsänderung von Dbp5 statt (Lund und Guthrie, 2005; Tran et al., 2007). Die lokale Aktivierung von Dbp5 und die Hydrolyse von ATP zu ADP bewirkt eine Konformationsänderung des mRNPs (Tieg und Krebber, 2012). Dabei werden die Exportfaktoren Mex67 und Nab2 von der mRNA dissoziiert (Lund und Guthrie, 2005; Tran et al., 2007).

\subsection{Die mRNA-Exportrezeptoren in S. cerevisiae}

Die bisher bekannten mRNP-Exportrezeptoren sind Xpo1 und das Heterodimer Mex67Mtr2, die Existenz weiterer Rezeptoren wird jedoch diskutiert (Carmody und Wente, 2009; Dieppois et al., 2006; Hieronymus und Silver, 2003).

In der Hefe ist der heterodimere Exportrezeptor Mex67-Mtr2 hauptsächlich für den Export von mRNAs verantwortlich (Segref et al., 1997). Weiterhin exportiert Mex67-Mtr2 auch die prä-ribosomale Untereinheiten und die Telomerase-RNA TLC1 in das Zytoplasma (Faza et al., 2012; Wu et al., 2014; Yao et al., 2007). Die Rekrutierung von Mex67-Mtr2 findet über RNA-bindende Proteine, den sogenannten mRNA-Adaptoren statt. Zu den derzeit bekannten Adaptoren, die mit den mRNAs in das Zytoplasma pendeln, gehören Npl3, Gbp2, Hrb1 und Nab2. Sie können direkt und RNA-unabhängig mit Mex67 interagieren (Gilbert und Guthrie, 2004; Hacker und Krebber, 2004; Hackmann et al., 2014; Iglesias et al., 2010; Windgassen und Krebber, 2003). 
Zusätzlich helfen weitere RNA-Bindeproteine bei der Beladung von Mex67-Mtr2 auf die mRNA, zu denen Yra1, Sub2 und Hpr1 zählen, jedoch dissoziieren sie vor dem Durchtritt am NPC von der mRNA und verbleiben im Zellkern (Zenklusen et al., 2002).

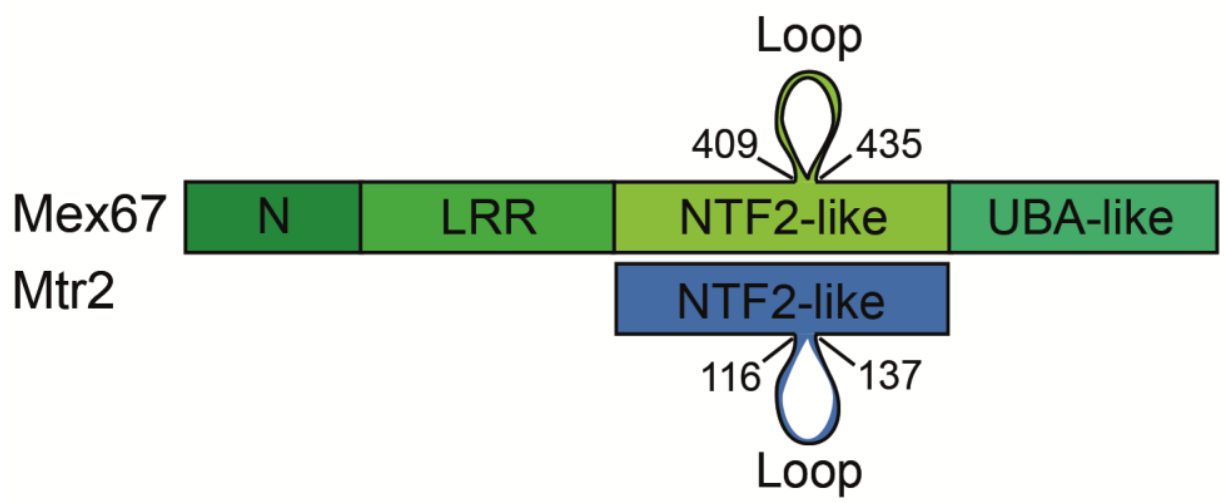

Abbildung 4: Schematische Darstellung des heterodimeren mRNA-Exportrezeptors Mex67-Mtr2. Mex67 (grün) besteht aus einer N-terminalen Domäne $(\mathrm{N})$, einer flankierenden Region mit Leucin-reichen Sequenzwiederholungen (LRR), einer NTF2-ähnlichen Domäne und einer Ubiquitin-assoziierten (UBA)-Domäne. Mtr2 (blau) besteht aus der NTF2-ähnlichen Domäne, die mit Mex67 interagiert. Beide Proteine enthalten für S. cerevisiae spezifische ,loop“-Strukturen. Modifiziert nach (Faza et al., 2012; Yao et al., 2007).

Die N-terminale Domäne und die LRR-Domäne von Mex67 stellen die Bindedomäne für Yra1 dar (Niño et al., 2013). An diese Bereiche von Mex67 schließt sich die „nuclear transport factor 2“ (NTF2)-ähnliche Domäne an (Yao et al., 2007). Sie interagiert mit Mtr2 und beinhaltet in S. cerevisiae eine ,loop“-Struktur (Abbildung 4). Auch bei Mtr2 wurde diese ,loop“-Struktur entdeckt (Yao et al., 2007). Diese „loop“-Strukturen besitzen positivgeladene Aminosäuresequenzen und können so mit artifizieller RNA oder der 5S-rRNA, die ein negativ-geladenes Phosphatrückgrat enthalten, interagieren (Aibara et al., 2015; SantosRosa et al., 1998; Yao et al., 2007). Zusätzlich bindet die NTF2-ähnliche Domäne im Komplex mit Mtr2 an die FG-reichen Aminosäuresequenzwiederholungen, um die Translokation des gebundenen mRNPs zu unterstützen (Sträßer et al., 2000). Am C-Terminus befindet sich die Ubiquitin-assoziierte (UBA)-Domäne, sie wird kompetitiv entweder von Hpr1 oder den FG-reichen Aminosäuresequenzwiederholungen gebunden (Grant et al., 2002; Hobeika et al., 2009). Durch die Bindung von Mex67 mit Hpr1 kann der Exportrezeptor auf die mRNA geladen werden. Nach Dissoziation von Hpr1 erfolgt die Bindung mit den FG-Aminosäuresequenzwiederholungen der Nukleoporine und dadurch wird die anschließende Translokation begünstigt (Gwizdek et al., 2006; Hobeika et al., 2009). 
Der mRNA-Exportrezeptor Mex67-Mtr2 lokalisiert in der Zelle vorwiegend am NPC. Daher wird vermutet, dass Mex67-Mtr2 direkt vor dem nukleären Export auf die prozessierten und Protein-gebundenen mRNAs geladen wird und die Translokation durch den NPC vermittelt (Reed und Hurt, 2002). Zwar konnte über Chromatin-Immunpräzipitations-Experimente (ChIP) gezeigt werden, dass Mex67 auch co-transkriptional über die C-terminale UBADomäne auf die entstehende mRNA geladen wird, jedoch ist diese zeitige Bindung an die mRNPs sehr gering (Dieppois et al., 2006; Gwizdek et al., 2006).

Beim Export der mRNA beteiligt sich auch das Karyopherin Xpo1, dass durch das RanGTPase-System gesteuert wird (Stewart, 2010). Seine Hauptfunktion liegt jedoch eher im Transport von Proteinen, snRNAs und prä-ribosomalen Untereinheiten. Xpo1 erkennt und bindet nukleäre Exportsignale (NESs) und benötigt Ran-GTP für den Transport in das Zytoplasma (Fornerod et al., 1997). Im Zytoplasma wird durch GTP-Hydrolyse der transportierte Komplex aufgelöst und die Moleküle in die Umgebung entlassen, dabei wird Xpo1 freigesetzt und in den Zellkern zurücktransportiert (Stewart, 2010). In S. cerevisiae zeigten Mutationen des Exportrezeptors XPOI nur schwache Defekte im mRNA-Export (Neville und Rosbash, 1999). Adaptoren, die Xpo1 mit den zu exportierenden Molekülen verbinden, sind noch weitesgehend unbekannt. Nur für den Transport der prä-60S-ribosomalen Untereinheit wurde Nmd3 identifiziert (Gadal et al., 2001; Ho et al., 2000).

\subsection{Die mRNA-Exportadaptoren}

Während für den Xpo1-vermittelten Export der mRNA derzeit keine Adaptoren bekannt sind, wurden verschiedene Proteine für Mex67-Mtr2 identifiziert, dazu gehören, die bereits genannten pendelnden Adaptoren Np13, Nab2, Gbp2 und Hrb1. Während Nab2 durch Dbp5 auf der zytoplasmatischen Seite des NPC abgelöst wird (Tran et al., 2007), bleiben Npl3, Gbp2 und Hrb1, die zur Gruppe der Serin/Arginin-reichen Proteine gehören, bis zur Translation an die mRNA gebunden (Hackmann und Krebber, 2014; Windgassen et al., 2004).

\subsubsection{Die Serin/Arginin-reichen Proteine}

In S. cerevisiae existieren drei Serin/Arginin (SR)-reiche Proteine, Npl3, Gbp2 und Hrb1. Sie verfügen ebenso wie die SR-reichen Proteine der höheren Eukaryoten in der sogenannten SR/RGG-Domäne über Serin/Arginin-reiche Dipeptidwiederholungen, die von 
Argenin/Glycin/Glycin (RGG)-Tripeptiden flankiert sind (Birney et al., 1993). In höheren Eukaryoten fungieren die SR-Proteine jedoch hauptsächlich als alternative Spleißingfaktoren. Vier von ihnen pendeln wie die Hefeproteine zwischen Zellkern und Zytoplasma hin und her, SRSF1, SRSF3, SRSF7 und SRSF10 (Twyffels et al., 2011). In Hefe verfügen die SR-Proteine über zwei bis drei „RNA-recognition motifs“ (RRMs) (Abbildung 5) (Gilbert et al., 2001; Hacker und Krebber, 2004). Alle drei SR-Proteine dissoziieren im Zytoplasma erst während der Translation von der mRNA und werden dann über die NLS-Sequenz in der SR/RGG-Domäne von ihrem Importrezeptor Mtr10 erkannt und zurück in den Zellkern transportiert (Gilbert et al., 2001; Hacker und Krebber, 2004). Dabei weisen alle drei SR-Proteine im Gleichgewichtszustand eine nukleäre Lokalisation auf (Hackmann et al., 2014).

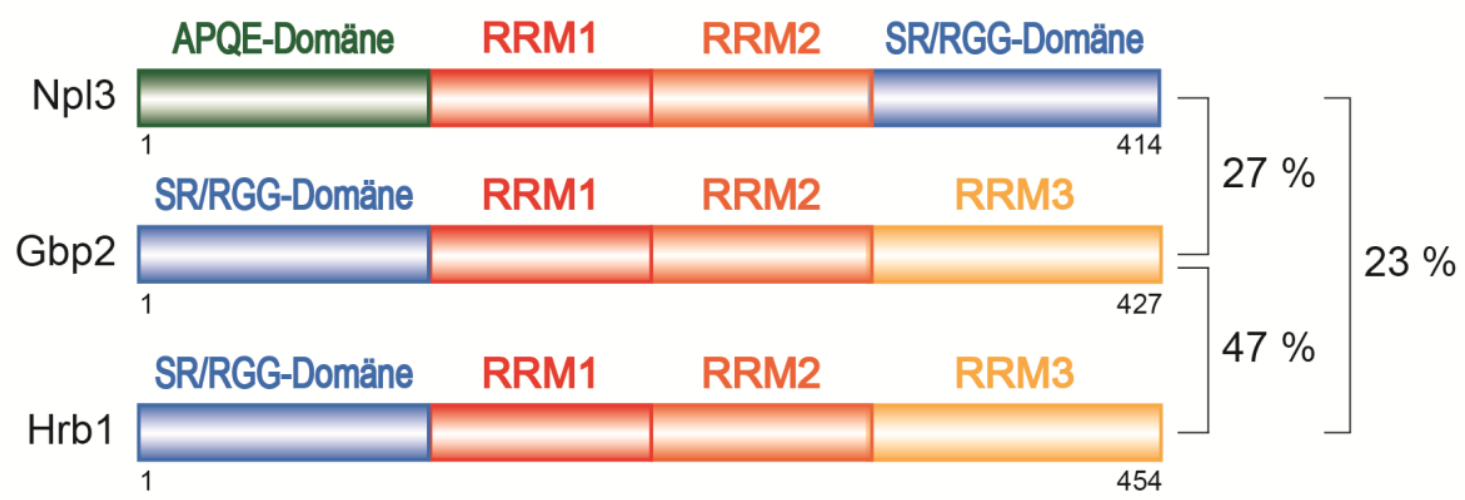

Abbildung 5: Die Domänenabfolge der SR-Proteine. In grün ist die N-terminale APQE-Domäne von Npl3 dargestellt, daraufhin folgen zwei RNA-Erkennungsmotive RRM1 und RRM2 (rot und orange) und in blau die C-terminale SR/RGG-Domäne. Im Gegensatz zu Np13 besitzen Gbp2 und Hrb1 keine APQE-Domäne, sondern ein zusätzliches RNA-Erkennungsmotiv RRM3 (gelb), das RNA-unabhängig mit dem THO-Komplex interagiert. Die Identitäten der Aminosäuresequenzen sind in Prozent angegeben. APQE: Alanin (A), Prolin (P), Glutamin (Q) und Glutaminsäure (E); RGG: Arginin (R)-Glycin (G)-Glycin (G) ; SR: Serin-Arginin (Hacker und Krebber, 2004).

\subsubsection{Npl3}

Npl3 ist ein multifunktionales mRNA-Bindeprotein und beteiligt sich an verschiedenen mRNA-abhängigen Prozessen (Santos-Pereira et al., 2014). Es besteht aus einer Nterminalen Domäne, die eine sich wiederholende Aminosäuresequenz APQE besitzt und deren Funktion unbekannt ist (Deka et al., 2008), zwei „RNA-recognition motifs“ (RRMs) (Birney et al., 1993; Bossie et al., 1992) und einer C-terminalen SR/RGG-Domäne, die unspezifisch einzelsträngige Nukleinsäuren binden kann (Abbildung 5) (Birney et al., 1993). Npl3 ist dem SFSR1 in höheren Eukaryoten besonders homolog (Birney et al., 1993; Twyffels et al., 2011). 
Während der Transkriptionsinitiation wird Npl3 auf die entstehende prä-mRNA geladen (Lei et al., 2001). Nach der Beladung unterstützt Npl3 die co-transkriptionale Rekrutierung von Spleißingfaktoren, die zu den frühen Spleißing-Komplexen (U1- und U2-snRNP) gehören (Kress et al., 2008). In ,high-throughput“ Experimenten wurde gezeigt, dass die Deletion des NPL3 Genes zu einer leichten Akkumulation von intronhaltigen prä-mRNAs im Zellkern führt (Kress et al., 2008). Außerdem konkurriert Npl3 mit frühzeitigen 3'-Prozessierungs-, Polyadenylierungs- und Terminationsfaktoren an kryptischen Polyadenylierungssignalen (Bucheli und Buratowski, 2005; Bucheli et al., 2007; Dermody et al., 2008). Diese Funktion wird am 3'-Ende der prä-mRNA durch die Dephosphorylierung von Npl3 am Serinrest-411 über die nukleäre Phosphatase-Aktivität von Glc7 aufgehoben (Gilbert und Guthrie, 2004; Izaurralde, 2004). Auch führt diese Dephosphorylierung von Npl3 am Serinrest-411 zu einer verstärkten Bindung mit dem Exportrezeptor Mex67-Mtr2 (Gilbert und Guthrie, 2004).

Neben dem mRNA-Transport wurde für Npl3 auch eine Transportfunktion der prä-60S-ribosomalen Untereinheit beschrieben. Mutationen im NPL3 Gen führten zu einem Exportblock der prä-60S-Untereinheit (Hackmann et al., 2011). Mit Hilfe der Bindung von Npl3 an die FG-reichen Elemente der Nukleoporine wird der Export der prä-60S-Untereinheit unterstützt. Interessanterweise bindet dabei Npl3 unabhängig von Mex67 an die Export kompetente prä-60S-Untereinheit (Hackmann et al., 2011).

Nach erfolgreichem Export der prä-60S-Untereinheit und der Export-kompetenten mRNPs, bleibt Npl3 an die prä-60S-Untereinheit und an die zytoplasmatischen mRNAs gebunden und unterstützt durch Dimer- oder Oligomerisierung die Translationsinitiation (Baierlein et al., 2013; Windgassen et al., 2004). Dabei spielt die Bindung von Npl3 an Rpl10 bei der Bildung des 80S-Monosoms, des „ribosomes subunit joining“ an die mRNA, eine wichtige Rolle (Baierlein et al., 2013). Auch nach der Translationsinitiation bleibt Npl3 an die mRNA gebunden, da es nach Dichtegradienten-Zentrifugationsexperimenten mit den Polysomen co-präzipitiert vorliegt (Windgassen et al., 2004). Durch die Bindung des Karyopherins Mtr10 an die NLS-Sequenz in der SR/RGG-Domäne von Npl3 findet eine Ablösung des Proteins von der translatierenden mRNA statt (Windgassen et al., 2004) und Mtr10 transportiert Npl3 wieder in den Zellkern zurück (Senger et al., 1998). Unterstützt wird der Rücktransport von Npl3 durch die Phosphorylierung des Serinrestes-411 von Npl3 durch die zytoplasmatische Proteinkinase Sky1 (Gilbert et al., 2001; Yun und Fu, 2000). 
Als weitere posttranslationale Modifikation wird Npl3 neben Phosphorylierungen zusätzlich methyliert. Dabei wird Np13 durch die nukleäre Arginin-Methyltransferase Hmt1 an 17 Arginin-Resten in den RGG-Sequenzen der C-terminalen SR-Domäne dimethyliert (McBride et al., 2005). Diese posttranslationale Modifikation scheint die co-transkriptionale Rekrutierung von Npl3 an die prä-mRNA zu unterstützen (Wong et al., 2010). Doch welchen genauen Einfluss die Methylierungen auf die Funktion von Npl3 haben, ist noch weitesgehend unbekannt.

\subsubsection{Gbp2 und Hrb1}

Die Struktur von Gb2 und Hrb1 ist der von Npl3 sehr ähnlich, jedoch besitzen die SRProteine anstelle der APQE-Domäne ein drittes RRM, dass direkt mit dem THO-Komplex interagieren kann (Martínez-Lumbreras et al., 2015). Vorzugsweise binden die Proteine an intronhaltige prä-mRNAs und interagieren mit späten Spleißingfaktoren wie z. B. Prp17 (Hackmann et al., 2014). Hrb1 und Gbp2 sind zu 47 \% identisch in ihrer Aminosäuresequenz und gleichen sich in ihrer Domänenabfolge (Abbildung 5). Äquivalent zu Untersuchungen mit Npl3 zeigte sich bei einer Überexpression von GBP2 eine Akkumulation von poly $(\mathrm{A})^{+} \mathrm{RNA}$ im Zellkern und eine verminderte Wachstumsrate der Zellen (Flach et al., 1994; Windgassen und Krebber, 2003). Die Deletionen von HRB1 und GBP2 führen, ähnlich zur Deletion des NPL3 Genes zu keinen mRNA-Exportdefekten (Hackmann et al., 2011), sondern es wird eine Anreicherung nicht-prozessierter prä-mRNAs im Zytoplasma sichtbar, was auf eine Funktion von Gbp2 und Hrb1 in der mRNA-Qualitätskontrolle hindeutet (Hackmann et al., 2014). Vermutlich stabilisieren Gbp2 und Hrb1 den TRAMP-Komplex durch Interaktion an die entstehenden prä-mRNAs und im Fall von nicht-prozessierten mRNAs können diese für den Abbau markiert werden. Bei korrekt prozessierten und gespleißten RNAs dissoziiert der TRAMP-Komplex und Mex67-Mtr2 kann an die Adaptoren Gbp2 und Hrb1 binden und als Folge die korrekte und gereifte mRNA in das Zytoplasma transportieren (Hackmann et al., 2014).

\subsubsection{Nab2}

Ein weiteres RNA-Bindeprotein, das mit dem export-kompetenten mRNPs in das Zytoplasma pendelt, ist Nab2 (Anderson et al., 1993). Während der 3'-Prozessierung der prä-mRNA interagiert Nab2 mit dem entstehenden poly(A) ${ }^{+}$-Schwanz. Dabei kontrolliert Nab2 die Länge der Polyadenylierung, sodass 70 bis 90 Nukleotide angeheftet werden 
(Hector et al., 2002). Die Interaktion von Nab2 mit Mex67 wird iniziiert durch die Dissoziation von Yra1 von der mRNA (Iglesias et al., 2010; Kelly et al., 2007).

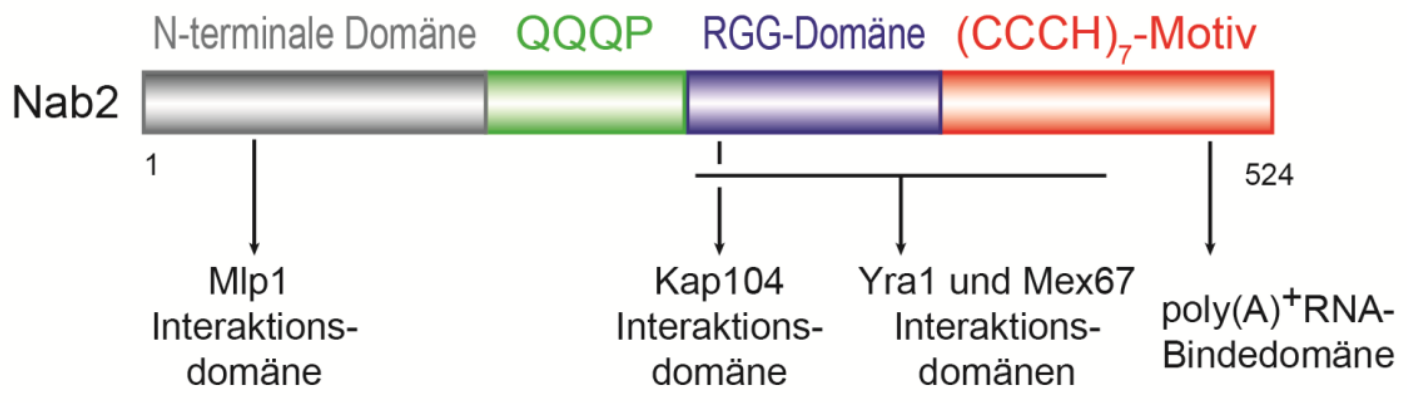

Abbildung 6: Die Domänenabfolge von Nab2. In grau ist die N-terminale Domäne gezeigt, darauf folgen das QQQP-Motiv (grün), die RGG-Domäne (blau) und das Zink-Fingermotiv (rot), welches C-terminal die RNA bindet. Die Interaktionspartner der jeweiligen Domänen sind eingezeichnet. Modifiziert nach (Marfatia et al., 2003).

Nab2 besitzt vier funktionale Domänen (Abbildung 6), eine einzigartige N-terminale Domäne mit ungefähr 100 Aminosäuren (Marfatia et al., 2003). Diese Domäne ist die Mlp1Interaktionsdomäne (Grant et al., 2008) und fördert so die Lokalisation der Export kompetenten mRNPs an den NPC für einen Export der mRNAs (Fasken et al., 2008; Soucek et al., 2012). Des Weiteren besitzt Nab2 eine Glutamin-reiche (QQQP) Domäne und eine RGG-Domäne, die ein nukleäre Lokalisationssequenz (NLS) besitzt. Diese NLS-Sequenz von Nab2 interagiert mit dem Importrezeptor Kap104 (Aitchison et al., 1996) und darüber wieder in den Zellkern zurücktransportiert werden, wo es für weitere Exportrunden bereitgestellt wird (Tran et al., 2007). Am C-Terminus besitzt Nab2 eine Zinkfinger$(\mathrm{CCCH})_{7}$-Domäne, die für die Bindung an polyadenylierte mRNA notwendig ist (Kelly et al., 2007). Die RGG- und die Zinkfingerdomäne wurden außerdem als Mex67- und Yra1Bindedomäne identifiziert (Iglesias et al., 2010). Im Zytoplasma wird die poly(A) ${ }^{+} \mathrm{RNA}$ nach Dissoziation von Nab2 an zytoplasmatisch lokalisiertes Pab1 gebunden (Sachs et al., 1987). Pab1 kann Funktionen von Nab2 im Zellkern übernehmen, obwohl es unter wildtypischen Bedingungen vorwiegend zytoplasmatisch lokalisiert. Beide Proteine, Nab2 und Pab1, kontrollieren die korrekte Länge der Polyadenylierung und führen in mutierter Form zu einer globalen Hyperadenylierung (Brune et al., 2005; Hector et al., 2002; Sachs und Davis, 1989; Viphakone et al., 2008). Es wurde gezeigt, dass Pab1 und Nab2 gleichzeitig an dieselbe polyadenylierte RNA binden und mit den gleichen Substraten interagieren können (Baejen et al., 2014; Schmid et al., 2012). Interessanterweise führt eine Depletion von Nab2 verstärkt zum Abbau von neu-synthetisierten poly(A) ${ }^{+}$RAs, durch das 
nukleäre Exosom (vor allem durch Rrp6) (Schmid et al., 2015). Dies weist darauf hin, dass Nab2 mit dem nukleären Exosom konkurriert und so die entstehende polyadenylierte RNA vor dem Abbau schützt (Saguez et al., 2008; Schmid und Jensen, 2013).

\subsection{Die Qualitätskontrolle der reifenden mRNAs}

\subsection{1 mRNA-Qualitätskontrolle während der mRNA-Maturierung}

Für das Überleben der Zelle ist es wichtig, dass die mRNAs, die in das Zytoplasma gelangen, korrekt sind und damit keine fehlerhaften Proteine entstehen, die toxisch für die Zelle sein können (Schmid und Jensen, 2013). Bereits während der Synthese der prä-mRNA erfolgt zu verschiedenen Zeitpunkten die Qualitätskontrolle (QC) der reifenden mRNAs. Jeder Prozessierungsschritt wird überprüft, und sobald ein Schritt nicht korrekt abläuft, wird die entstandene falsche mRNA im Zellkern durch verschiedene Mechanismen abgebaut (Das und Das, 2013). Verschiedene Abbau-Komplexe, wie z. B. das Exosom, dass die RNA in $3^{6}-5^{`}$ Richtung abbaut oder die $5^{6}-3^{`}$ Exonukleasen Rat1 und Xrn1, können falsche nukleäre oder zytomplasmatische RNAs beseitigen. Im Zellkern findet größtenteils eine cotranskriptionale Degradation der falschen mRNAs durch das Exosom und dessen CoFaktoren, wie z. B. den $\underline{\operatorname{Tr}} 4$ - $\underline{\text { Air-M}}$ tr4-olyadenylierungskomplex (TRAMP-Komplex), statt (Doma und Parker, 2007) (Abbildung 7).

Das evolutionär konservierte Exosom besitzt neun Untereinheiten, die in Hefe essentiell sind. Sechs der zentralen Untereinheiten (Rrp41, Rrp42, Rrp43, Rrp45, Rrp46 und Mtr3) bilden eine hexamere Ringstruktur mit einem zentralen Tunnel (Abbildung 7b) (Lykke-Andersen et al., 2011). Die drei Untereinheiten Rrp4, Rrp40 und Cs14 setzen sich zu einer trimeren Kappenstruktur oberhalb der Ringstruktur zusammen (Abbildung 7b). Diese zentrale Sruktur besitzt in S. cerevisiae kein katalytisches Zentrum (Liu et al., 2006), deshalb intagiert das Proteingerüst mit assoziierten katalytischen Untereinheiten, wie z. B. die Exo-/Endonuklease Dis3/Rrp44 (Dziembowski et al., 2007). Die zentralen neun Untereinheiten des Exosoms befinden sich sowohl im Zellkern als auch im Zytoplasma, doch unterscheiden sich die assoziierten Enzyme in den Kompartimenten voneinander (Houseley et al., 2006). So beinhaltet das Exosom im Zellkern z. B. eine weitere Exonuklease, das Enzym Rrp6 (Fox und Mosley, 2015; Mitchell et al., 1997).

Neben dem Exosom sind die Co-Faktoren für die mRNA-Qualitätskontrolle wichtig. So markiert der TRAMP-Komplex die falschen oder instabilen Transkripte und hängt einen 
kurzen (ca. fünf Nukleotid-langen), einzelsträngigen poly(A)-Schwanz an ihr 3'-Ende (LaCava et al., 2005; Vaňáčová et al., 2005) (Abbildung 7a). Dieser poly(A)-Überhang markiert solche RNAs, die vom Exosom abgebaut werden sollen (Kong et al., 2013). Der TRAMP-Komplex besteht aus drei Komponenten, die hoch konserviert in Eukaryoten vorliegen, die poly(A)-Polymerase Trf4 oder Trf5, ein Zinkfingerprotein Air1 oder Air2 und die RNA-Helikase Mtr4 (Bernstein et al., 2008; LaCava et al., 2005; Wyers et al., 2005).

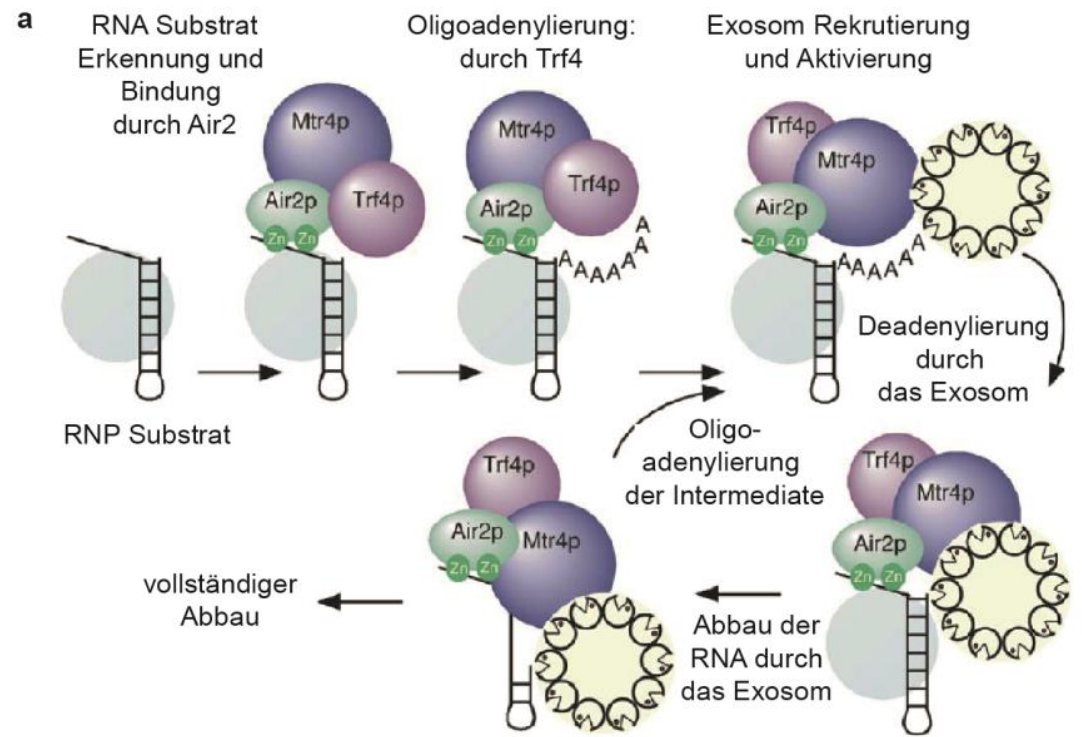
b Aufbau des
nukleären Exosoms in S. cerevisiae:

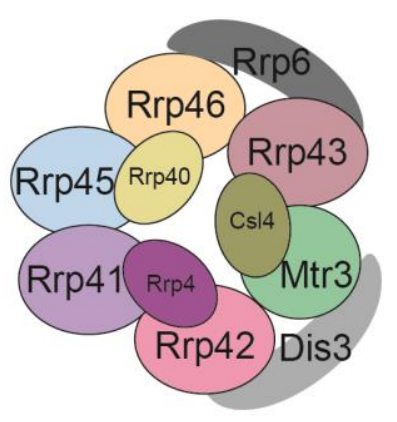

Abbildung 7: Die mRNA-Qualitätskontrolle im Zellkern. a, Der TRAMP-Komplex interagiert über die Zinkfinger-Domäne von Air1/2 mit der RNA oder dem RNP-Substrat. Anschließend wird die gebundene RNA durch Trf4 oligoadenyliert. Das Exosom wird durch den TRAMP-Komplex rekrutiert und baut die mRNA in 3'-5'-Richtung ab. Modifiziert nach (LaCava et al., 2005). b, Die Darstellung zeigt den strukturellen Aufbau des nukleären Exosoms in S. cerevisiae. Dis3 und Rrp6 sind die katalytischen Einheiten des nukleären Exosoms.

Der TRAMP-Komplex existiert in zwei verschiedenen Varianten, einmal als TRAMP4- oder als TRAMP5-Komplex (Anderson und Wang, 2009). Der TRAMP4-Komplex besteht aus der Trf4, Air1/2 und Mtr4 und ist vorwiegend für die Qualitätskontrolle der mRNA notwendig. Der TRAMP5-Komplex, bestehend aus Trf5, Air1 und Mtr4, lokalisiert im Nukleolus und ist hauptsächlich an der Prozessierung von nukleolarer rRNA beteiligt (Paolo et al., 2009).

Trf4/Trf5 werden als „,noncanonical“ poly(A)-Polymerasen bezeichnet und gehören zur Familie der Nukleotidyl-Transferasen (Aravind und Koonin, 1999). Während in S. cerevisiae die poly(A)-Polymerase Pap1 durchschnittlich einen poly(A) ${ }^{+}$Schwanz zwischen 70 bis 90 Nukleotide herstellt, fügen die Polymerasen Trf4/5 einen poly $(\mathrm{A})^{+}$Schwanz von 5 bis 10 Nukleotiden an das $3^{6}$-Ende von mRNAs an, diese Oligoadenylierung markiert die falsche mRNA für den späteren Abbau. 
Es wurde gezeigt, dass die RNA-Bindeproteine Air1/2 einen internen Kontakt zwischen der RNA und Trf4/Trf5 herstellen (Hamill et al., 2010). Der RNA-Kontakt über Air1/2 ist wichtig, da die poly(A)-Polymerasen selbst keine RNA-Bindedomäne besitzen und deshalb ohne die Zinkfingerproteine inaktiv sind (Vaňáčová et al., 2005). Air1 und Air 2 werden zwar von verschiedenen Genen in S. cerevisiae synthetisiert, gleichen sich aber zu $45 \%$ in ihrer Aminosäuresequenz. Deshalb könnte es sein, dass beide Proteine die gleichen Funktionen innerhalb des TRAMP-Komplexes übernehmen (Anderson und Wang, 2009). Die RNA-Helikase Mtr4 kontrolliert die Länge des Oligo(A)-Anhangs und entwindet etwaige sekundäre RNA-Strukturen des 3' Endes, wodurch das Exosom nachfolgend die unstrukturierten mRNAs abbauen kann (Jia et al., 2011) (Abbildung 7a).

Der TRAMP-Komplex kann unterschiedlichste Substrate für den Abbau markieren z. B. tRNAs (,transfer“ RNAs), snoRNAs (,small nucleolar“ RNAs), snRNAs, ncRNAs (,noncoding“" RNAs), rRNAs (,ribosomal" RNAs) oder mRNAs (Allmang et al., 1999; van Hoof et al., 2000; Houseley und Tollervey, 2009; Milligan et al., 2005; Wang et al., 2008). Dementsprechend erkennt der TRAMP-Komplex vermutlich keine gemeinsamen Merkmale in der RNA-Struktur oder Sequenz, aber möglicherweise kann er Besonderheiten von RNAProtein-Strukturen identifizieren (Houseley et al., 2006). Wie genau der TRAMP-Komplex falsche mRNAs erkennt und sie für den Abbau kennzeichnet, ist derzeit nicht vollständig aufgeklärt. Doch konnte durch die CRAC-Methode (,crosslinking“ und Analyse von cDNAs) der TRAMP4-Komplex, speziell Trf4 und Mtr4, an der 5'-Region der entstehenden RNA nahe des Transkriptionsstartpunktes identifiziert werden (Bohnsack et al., 2012). Des Weiteren konnte mit Hilfe dieser Methode eine hohe Bindungsaffinität dieser Faktoren zu Intron-Sequenzen gezeigt werden (Paolo et al., 2009). Außerdem bestätigten verschiedene Interaktionsstudien unabhängig voneinander, dass der TRAMP-Komplex mit den Spleißingfaktoren in Kontakt tritt und somit das Spleißen und die Qualität der prä-mRNA kontrolliert (Hackmann et al., 2014; Kong et al., 2013). Zentrale Faktoren sind dabei Gbp2 und Hrb1, die den TRAMP-Komplex an Intron-haltige mRNAs rekrutieren und der Degradation zuführen (Hackmann et al., 2014). Bei korrekter Reifung der mRNA findet wahrscheinlich ein Austausch statt: Anstelle des TRAMP4-Komplexes bindet Mex67-Mtr2 an die SR-Proteine und der mRNP wird für den Transport in das Zytoplasma vorbereitet (Hackmann et al., 2014). 


\subsection{2 mRNA-Qualitätskontrolle auf der nukleären Seite des NPCs}

Auf der nukleoplasmatischen Seite des NPCs sind weitere Proteine verankert, die vor dem mRNA-Export die Qualität der mRNA final kontrollieren. Zu diesen Proteinen gehören Mlp1 und Mlp2. Diese Proteine interagieren mit den mRNA-Adaptoren Npl3, Gbp2, Hrb1 und Nab2 und können so die korrekte Komposition des mRNPs überprüfen (Bretes et al., 2014; Green et al., 2003; Hackmann et al., 2014; Niepel et al., 2013). Es konnte gezeigt werden, dass die Störung der Interaktion von Mlp1 und Nab2 zu geringerer mRNA-Export Effizienz führt (Fasken et al., 2008). Dabei halten die Faktoren der mRNAQualitätskontrolle jene mRNAs zurück, die keine vollständige 3'-Endprozessierung durchlaufen haben (Hector et al., 2002). In einem „Screen“ mit einem Deletionsstamm des MLP1 Genes wurde weiterhin gezeigt, dass vorwiegend Intron-haltige prä-mRNAs in das Zytoplasma entweichen, wenn zusätzlich der Spleißingfaktor PRP18 mutiert vorliegt (Galy et al., 2004). Die Autoren konnten somit aufzeigen, dass Mlp1 essentiell für die mRNAQualitätskontrolle wird, wenn der Spleißprozess sub-optimal verläuft. Im Gegensatz dazu führt die Überexpression des MLP1 Genes zur Akkumulation Intron-haltiger ReportermRNAs im Zellkern (Galy et al., 2004).

Verschiedene weitere NPC-assoziierte Faktoren gehören neben Mlp1/2 zur mRNAQualitätskontrolle am Kernporenkomplex (Abbildung 8). So wurden beispielsweise genetische Interaktionen von TOM1 mit RRP6 und $M L P 1 / 2$ gefunden, was vermuten lässt, dass Tom1 an der NPC-assoziierten mRNA-Qualitätskontrolle beteiligt ist (Iglesias et al., 2010). Die E3-Ubiquitinligase Tom1 löst Yra1 durch Ubiquitinylierung vom Exportkompetenten mRNP am NPC ab (Iglesias et al., 2010).

Weitere Proteine sind Pml39 und Ulp1, sie lokalisieren durch die Interaktion mit Nup60 und Mlp1 exklusiv am NPC (Abbildung 8) (Galy et al., 2004; Palancade et al., 2005; Zhao et al., 2004). Die ,_small úbiquitin-like modifier“ (SUMO)-Protease Ulp1 hält durch Sumolierung des THO-Komplexes nicht-prozessierte prä-mRNAs im Zellkern zurück (Bonnet et al., 2015; Lewis et al., 2007). Die NPC-assoziierte Endonuklease Swt1 ist mit dem NPC verbunden und kann nicht-prozessierte prä-mRNAs durch dessen Endonuklease-Aktivität abbauen (Skružný et al., 2009). 


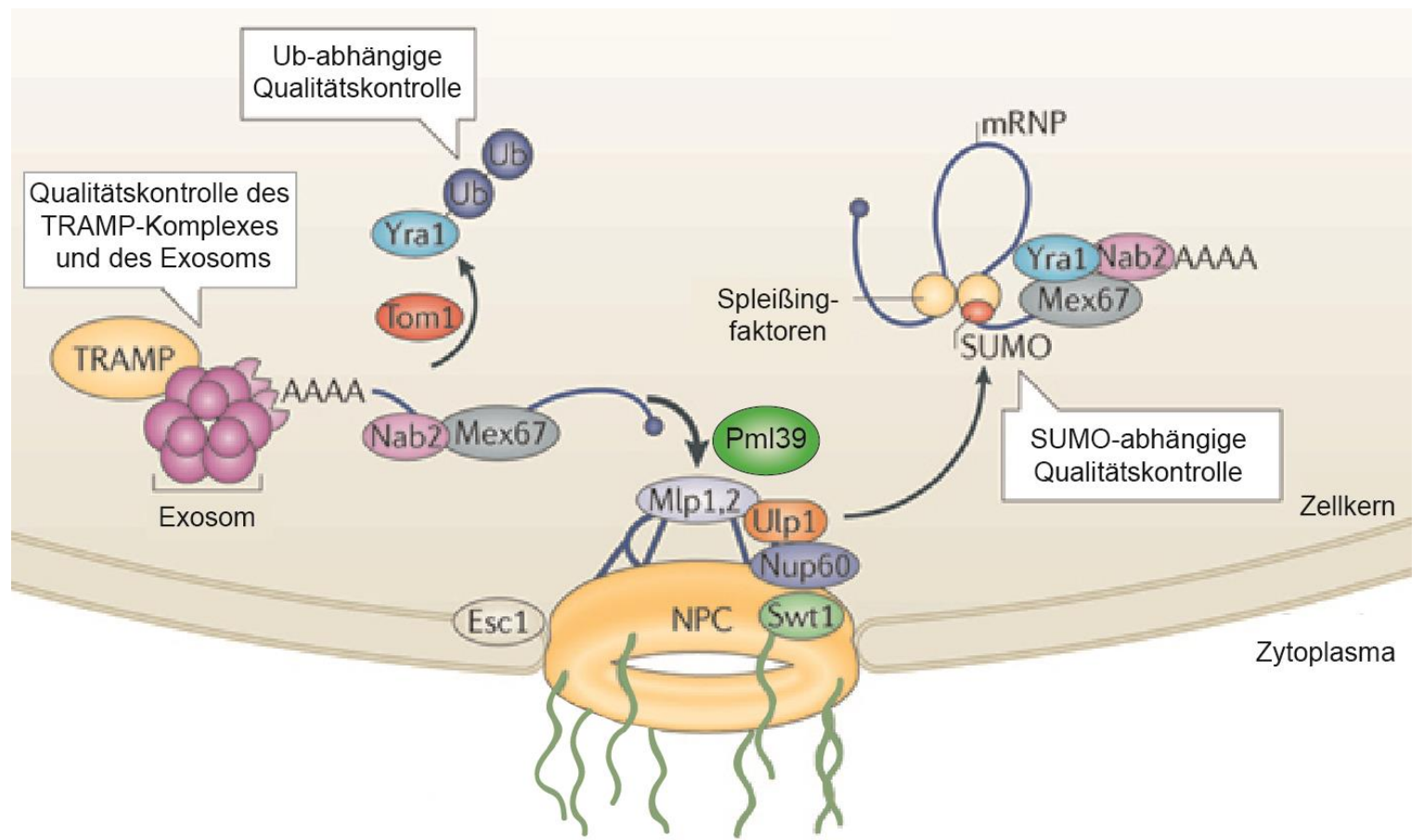

Abbildung 8: Die mRNA-Qualitätskontrolle am Kernporenkomplex. Vor der Translokation der mRNPKomplexe werden diese kontrolliert und alle nicht-pendelnden Proteine entfernt. So unterstützt die E3Ubiquitinligase Tom1 durch Ubiquitinylierung (Ub) die Dissoziation von Yra1 von den mRNAs. Die SUMOProtease Ulp1 wird durch die Interaktion mit Nup60 und Mlp1/Mlp2 am NPC lokalisiert, markiert die mRNPKomplexe durch Sumolierung (SUMO) und hält sie dadurch im Zellkern zurück. Das Modell wurde modifiziert nach (Tutucci und Stutz, 2011).

\subsection{Der mRNA-Transport während zellulären Stresses}

\subsubsection{Die Kontrolle der Genexpression bei der Stressantwort}

Die optimalen Wachstumsbedingungen von $S$. cerevisiae liegen in einem relativ eingeschränkten Bereich. Bei einer Temperatur von $25^{\circ} \mathrm{C}$ bis $30^{\circ} \mathrm{C}$ wachsen die Zellen problemlos (Morano et al., 2012). Allerdings muss die Zelle auch in der Lage sein, moderate Abweichungen wie Temperaturänderungen, $\mathrm{pH}$-Veränderungen oder schwankende Osmolarität zu tolerieren (Bond, 2006). Dabei kann es zur Zerstörung von makromolekularen Komplexen oder zur Falschfaltung von Proteinen kommen. Die Zellen reagieren auf den umgebungsbedingten Stress durch Expression von Stress-spezifischen Genen. Diese Gene werden als Hitzeschockgene bezeichnet und codieren für die Hitzeschockproteine (Hsps) (Bond, 2006). Bei Temperaturen ab $37^{\circ} \mathrm{C}$ startet die Zelle ein schützendes Trankriptionsprogramm, das man als Hitzeschock-Antwort bezeichnet. S. cerevisiae kann kurzfristig bis zu einer Temperatur von $42^{\circ} \mathrm{C}$ wachsen, ist aber nicht in der Lage, diese Temperaturen lange zu verkraften, da auch die RNA-Polymerase II bei andauerndem Hitzestress inaktiviert wird (Yamamoto et al., 2008). 
In Eukaryoten ist die Proteinfamilie der Hitzeschock-Transkriptionsfaktoren ein entscheidender Modulator für die Stressantwort. In $S$. cerevisiae gibt es die Transkriptionsfaktoren Hsf1, Msn2 und Msn4, die für die Hitzeschockgenexpression essentiell sind. Das Msn2/4 Regulon wird nicht nur bei einem Hitzestress, sondern auch anderen Stressarten aktiviert. Deshalb wird es als „Enviromental stress response“ (ESR) bezeichnet.

\subsubsection{Msn2/4:}

Msn2 und dessen homologes Protein Msn4 wurden Mitte der neunziger Jahre als Proteine identifiziert, die unter verschiedenen Stressbedingungen für die Expression von einer relativ großen Anzahl an Genen verantwortlich, aber nicht für das Überleben unter normalen Wachstumsbedingungen notwendig sind (Martínez-Pastor et al., 1996; Schmitt und McEntee, 1996). Die Erkennungssequenz für Msn2/4 befindet sich im Promotorbereich des jeweiligen Genes und wurde bereits in Wieser et al. (1991) beschrieben. Sie besteht aus einer pentameren Sequenz, dem CCCCT. Diese Erkennungssequenz wird als „stress responsive

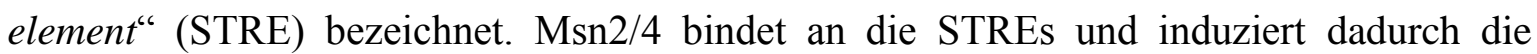
Transkription verschiedener Gene in unterschiedlichen Stresssituationen (Martínez-Pastor et al., 1996). Msn2/4 Zielgene werden z. B. nach einem Hitzestress, einem oxidativen Stress oder in der späten stationären Phase induziert (Trott und Morano, 2003)

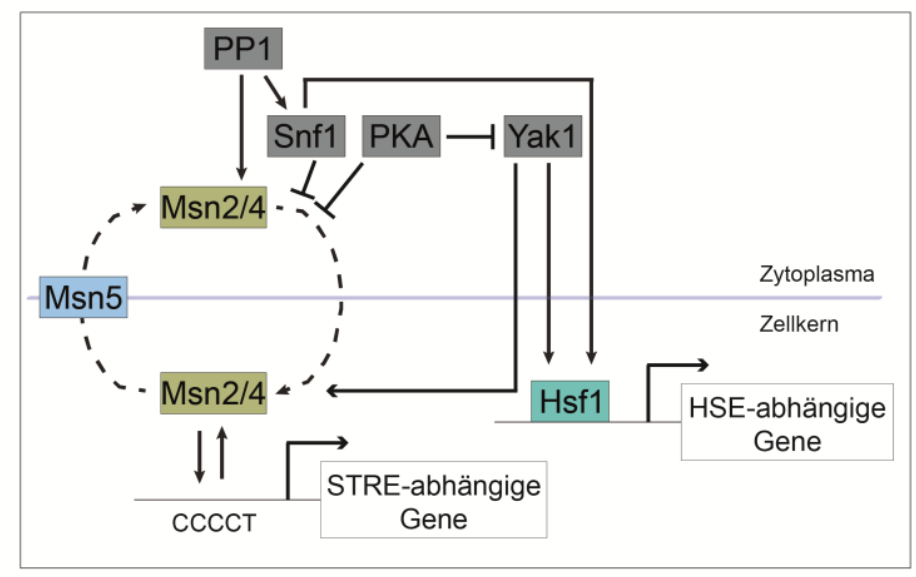

Abbildung 9: Regulationsmechanismen der Transkriptionsfaktoren Msn2/4 und Hsf1. Die Regulation von Msn2/4 und Hsf1 ist grafisch dargestellt. Msn2/4 wird während des Stresses durch die Proteinphosphatase PP1 dephosphoryliert und lokalisiert dadurch in den Zellkern, wo es an die Stress-spezifischen Elemente (STREs) in den Pomotorbereichen bindet und die Expression von Zielgenen anschaltet. Hsf1 dagegen ist grundlegend im Zellkern lokalisiert und bindet an Zielgene, die Hitzeschockelemente (HSEs) in ihren Promotoren enthalten. Durch die Regulierung der Kinasen Snf1 und Yak1 wird Hsf1 phosphoryliert und dadurch aktiviert. Das Modell wurde modifiziert nach (Morano et al., 2012). 
Unter normalen Wachstumsbedingungen übernimmt der Signalweg der zyklischen-AMP (cAMP)- Proteinkinase-A (PKA) die transkriptionale Kontrolle und phosphoryliert Msn2/4. Durch die Phosphorylierungen ist der Transkriptionsfaktor im Zytoplasma lokalisiert und es kann dementsprechend eine Zielgenaktivierung verhindert werden (Görner et al., 1998; De Wever et al., 2005). Bei Stress dephosphoryliert die Proteinphosphatase PP1 hingegen die PKA- und Snf1 abhängigen Phosphorylierungen von Msn2 (Abbildung 9) (Lenssen et al., 2004; Mayordomo et al., 2002; De Wever et al., 2005). Weiterhin kann PP1 durch die Dephosphorylierung der Proteinkinase Snf1 diese negativ regulieren, verhindert dadurch die Phosphorylierung von Msn2 (De Wever et al., 2005) und verwendet somit zwei verschiedene Wege um die Aktivität von Msn2 zu kontrollieren (Abbildung 9). Durch die Dephosphorylierung von Msn2 bei kurzzeitigem Stress gelangt das Regulon Msn2/4 sofort in den Zellkern (Jacquet et al., 2003). Dieser Transport läuft schnell ab und verursacht die sofortige Expression der Stress-spezifischen Gene.

Lang andauernder Stress führt jedoch zum Abbau von Msn2 und Msn4 im Zellkern, um eine chronische Aktivierung der Zielgene zu verhindern und potentielle Adaptionsmechansimen zu unterbinden (Lallet et al., 2004).

Die, in Abbildung 9 dargestellte Proteinkinase Yak1 phosphoryliert bei geringen Glukosebedingungen Msn2, Msn4 und Hsf1 und ist somit eines der wenigen Proteine, das alle drei Transkriptionsfaktoren gleichzeitig beeinflussen kann (Griffioen et al., 2001; Lallet et al., 2004; Lee et al., 2008).

\subsubsection{Hsf1}

In S. cerevisiae wird der Hitzeschock-Transkriptionsfaktor durch das HSF1 Gen codiert, das auch unter normalen Wachstumsbedingungen für das Überleben der Zelle essentiell ist. Die Transkription der Zielgene von Hsf1 führt zur Synthese von unterschiedlichen Proteinen, die in der Proteinfaltung, im Abbau, in der Entgiftung, in der Energiegewinnung, im Kohlenhydratmetabolismus und in der Zellwandorganisation eine Rolle spielen (Hahn und Thiele, 2004; Yamamoto et al., 2005). In Säugetieren besteht der Transkriptionsaktivator aus vier verschiedenen Isoformen. Dabei reguliert HSF1 primär die Hitzestressantwort, während HSF2 eine Rolle in der embryonalen Genexpression spielt. Die Funktionen von HSF3 und HSF4 sind derzeit noch nicht genau bekannt, aber es wird vermutet, dass sie mit HSF1 interagieren und dadurch die Genexpression regulieren (Akerfelt et al., 2010). 


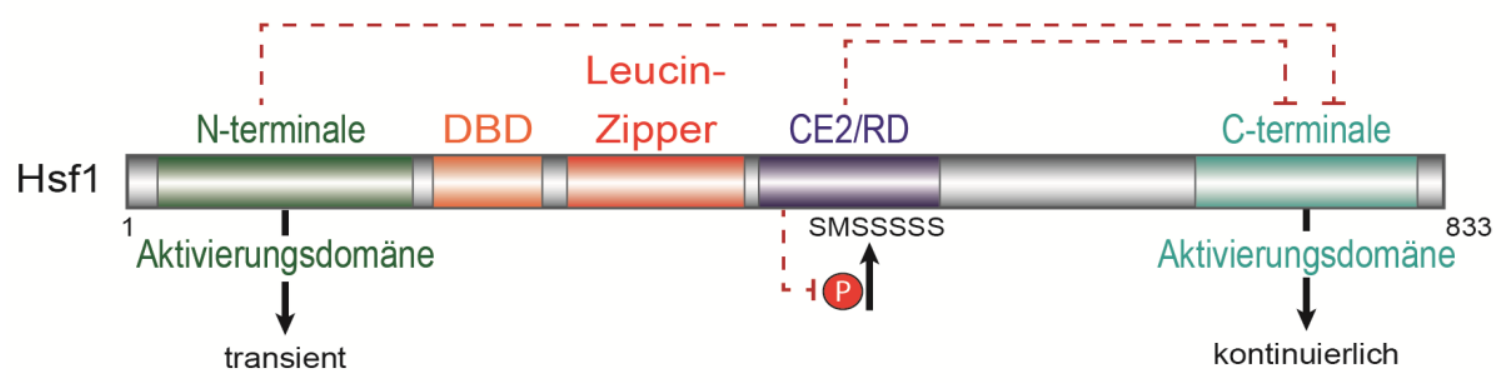

Abbildung 10: Der Aufbau und der Regulierungsmechanismus von Hsf1. Eingezeichnet sind die relevanten Domänen des Transkriptionsfaktors Hsf1. Die rot-gestrichelten Linien zeigen die regulatorische Verbindung zwischen der NTA (N-terminalen Aktivierungsdomäne in grün) und der CE2 (Kontrollelement 2)/RD (regulatorischen Domäne in lila) bezogen auf die CTA (C-terminale Aktivierungsdomäne in türkis). Die Serin-reiche Region innerhalb der RD wird durch unbekannte Proteinkinasen phosphoryliert, wodurch die Aktivierung der CTA unterdrückt wird. Die NTA unterstützt die transiente Transkriptionsaktivierung, während die CTA für die kontinuierliche Aktivierung verantwortlich ist. DBD bezeichnet die DNA-Bindedomäne (orange) und die Leucinzipper-Sequenz ist in rot dargestellt. Hsf1 besitzt 833 Aminosäuren und $\mathrm{P}$ entspricht den Phosphorylierungen in der CE2-Domäne. Modell nach (Verghese et al., 2012).

Die beschriebenen Strukturelemente des Transkriptionsfaktores sind hoch konserviert (Abbildung 10). Sie beinhalten N-terminal eine Hefe-spezifische Sequenz mit 150 Aminosäuren (Sorger, 1990), eine Helix-turn-Helix DNA-Bindedomäne (DBD), flankiert von einem Leucinzipper-Motif, welches für die Trimerisierung und die Aktivierung wichtig ist. Anschließend folgt eine lose definierte Serin-reiche regulatorische Domäne (CE2/RD) und C-terminal schließt sich die transkriptionale Aktivierungsdomäne an (Trott und Morano, 2003).

Hsf1 kann mit einem pentamerischen Hitzeschockelement (HSE), definiert als perfekt-wiederholende Erkennungssequenz (nTTCnnGAAnnTTCn), in der Promotorregion des induzierenden Genes interagieren (Sorger und Pelham, 1987). Daraus ergibt sich, dass Hsf1 die DNA als Trimer binden kann (Sorger und Pelham, 1987). Diese Erkennungssequenz kann aber auch in ihren Abständen variieren. So konnte durch die Bindung an das Metallothionin-Gen CUP1 gezeigt werden, dass Hsf1 in Folge von Hitzestress und oxidativen Stress auch untypische Wiederholung der HSE binden kann. Diese untypische Wiederholung der HSE setzt sich aus zwei nGAAn-Wiederholungen mit einem pentameren Spacer und darauffolgend einem weiteren Element zusammen (Liu und Thiele, 1996; Tamai et al., 1994). Auch in vitro DNase I ,footprint“ Analysen zeigten, dass Hsf1 verschiedene Varianten der untypischen HSEs binden kann (Yamamoto et al., 2005). Der Aufbau der HSE-Wiederholungen bestimmt das Verhalten und die Bindung von Hsf1 dramatisch. Für die Bindung eines untypischen HSEs mit 5 Basenpaaren „Spacer“ zwischen den nGAAn-Sequenzen darf Hsf1 weder phosphoryliert noch oligomerisiert vorliegen 
(Hashikawa et al., 2006). Phosphorylierungen begünstigen Protein-Proteininteraktionen bewirken eine Konformationsänderung der DBD-Domäne, was zu eine Deaktivierung von Hsf1 führt (Hashikawa et al., 2006). Darüber hinaus zeigt die C-terminale regulatorische Domäne von Hsf1, dass diese als Trimer nur perfekte HSE-Sequenzen, nicht aber an untypische HSE-Sequenzen binden kann (Hashikawa et al., 2006). Dies zeigt, wie vielschichtig die Bindung von Hsf1 an seine Zielgene ist und das viele Gene durch Hsf1 aktiviert werden können.

\subsubsection{Regulation des mRNA-Metabolismus bei Stress}

\subsubsection{Der Spleißprozess wird bei Stress inhibiert}

Neben der Expression von Stress-spezifischen Genen finden im Zellkern regulierende Prozesse statt, die u. a. das Spleißen von intronhaltigen Genen unterbindet (Bond, 2006). Es findet eine vollständige Akkumulation der prä-mRNAs mit Introns bei sechzig-minütigem Hitzestress statt (Yost und Lindquist, 1991). Diese Inhibierung dient dazu, dass sich die Zelle vollständig auf die Genexpression von Hitzeschockgenen konzentrieren kann und eine schnelle Stressantwort durchgeführt wird (Bond, 1988; Bracken und Bond, 1999).

\subsubsection{Der Export von regulären mRNAs wird bei Stress im Zellkern blockiert}

Zusätzlich zu Veränderungen der Transkription verursacht Stress sofortige Änderungen des mRNA-Transportes, die entscheidende physiologische Auswirkungen auf die Zelle haben (Morano et al., 2012). Beispielsweise akkumulieren die mRNAs, die unter normalen Wachstumsbedingungen exportiert werden (reguläre mRNAs), unter Hitzeschock ab $42^{\circ} \mathrm{C}$ im Zellkern, während Stress-spezifische Transkripte wie SSA4 bevorzugt in das Zytoplasma exportiert werden (Saavedra et al., 1996). Durch welche Mechanismen die regulären mRNAs im Zellkern zurückgehalten werden, ist derzeit weitesgehend unbekannt. Es konnte durch UV „crosslinking“ Experimente gezeigt werden, dass bei Hitze- und Salzstress das Adaptorprotein Npl3 nicht mehr an die poly $(\mathrm{A})^{+} \mathrm{RNA}$ gebunden vorliegt, sondern frei in der Zelle diffundiert (Krebber et al., 1999; Nanduri und Tartakoff, 2001). Einen weiteren Einfluss auf das Zurückhalten von poly(A) ${ }^{+}$RNA im Zellkern könnte die CWI-MAPProteinkinase Slt2 haben (Carmody et al., 2010). Slt2 phosphoryliert Nab2 bei Hitzestress an den Aminosäurestellen Threonin-178 und Serin-180 (in der Glutamin-reichen QQQP-Domäne) und könnte somit $\mathrm{Nab} 2$ von der poly(A) ${ }^{+} \mathrm{RNA}$ dissoziieren. In Wachstumsanalysen konnte gezeigt werden, dass die Überlebensrate der 
Phosphorylierungsmutante nab2-T178A/S180A gemeinsam mit der Deletionsmutante rip14/nup424 während Hitzestress drastisch abnahm (Carmody et al., 2010). Daraus schließen die Autoren, dass die Phosphorylierung von Nab2 wichtig für das Zurückhalten der regulären mRNAs sein könnte und womöglich das Wachstum unter normalen Wachstumsbedingungen nach überstandenem Stress fördert. Doch konnte dies nur in Zusammenhang mit der Deletionsmutante rip14/nup424 gezeigt werden, die Phosphorylierungsmutante nab2-T178A/S180A allein zeigte keinerlei Wachstumsdefekte nach einem Hitzestress. Interessanterweise lokalisiert Nab2 zusammen mit Yra1 und Mlp1 während des Stresses in sogenannten „nuclear foci“ (Carmody et al., 2010). Dies sind erstmalig beschriebene Akkumulationen von diesen Faktoren mit noch unbekannter Funktion. Folgendes Arbeitsmodell vereint diese Beobachtungen (Abbildung 11)

\subsubsection{Der Export von Stress-spezifischen Transkripten bei Stress}

Bei Stress werden Stress-spezifische Transkripte synthetisiert, diese codieren für Hitzeschockproteine (Hsps) und sind für das Überleben der Zelle bei Stress wichtig. Die Hsps fungieren als Chaperone und interagieren mit falschgefalteten Proteinen, um diese wiederherzustellen oder sie dem Abbau zu zuführen (Verghese et al., 2012). Der Transportmechanismus der Stress-spezifischen Transkripte ist derzeit noch weitgehend unbekannt. Analysen des Exports von Stress-spezifischen mRNAs, zeigen, dass nicht nur Exportfaktoren wie Mex67 und Rat7, sondern auch Rip1/Nup42 für den Export bei Hitzestress notwendig sind (Hurt et al., 2000; Saavedra et al., 1997). Darüber hinaus akkumulieren die Stress-spezifischen Transkripte an Transkriptions-assoziierten ,foci“ in rip14 und rat7-1 mutierten Zellen (Hilleren et al., 2001). Die Autoren schließen daraus, dass die Stress-spezifischen Transkripte nicht vom Transkriptionsapperat abgelöst werden und daher an dieser Stelle akkumulieren.

Interessanterweise haben die bisher bekannten Mex67 bindenden mRNA-Adaptoren Npl3, Nab2 und Yra1 vermutlich keinen Einfluss auf den Export von Stress-spezifischen Transkripten in das Zytoplasma (Carmody et al., 2010; Krebber et al., 1999; Rollenhagen et $a l .$, 2007). Es wurde zwar mittels RNA-Co-Immunpräzipitationsexperimenten (RIPs) gezeigt, dass Yra1 an Stress-spezifische RNAs binden kann (Rollenhagen et al., 2007). Doch zeigten die Autoren weiterhin mit Hilfe von Fluoreszenz in situ Hybridisierungsexperimenten (FISH), dass Yra1 nicht für den Export der Stress-spezifischen mRNA SSA4 notwendig ist und in den unterschiedlichen Mutanten von $Y R A 1$ wurde weiterhin Ssa4-GFP exprimiert und mittels Durchflusszytometrie eine zum Wildtyp vergleichbare Proteinmenge 
gemessen (Rollenhagen et al., 2007). Weitere derzeit bekannte Faktoren, die einen Einfluss auf den Export von Stress-spezifischen mRNAs haben könnten, sind die Proteine des THO-Komplexes. So wurde gezeigt, dass in Mutanten des THO-Komplexes hpr14, tho2 4 , mftld und thp2A, die SSA1-mRNA nach einem 30-minütigen Hitzestress bei $42^{\circ} \mathrm{C}$ im Zellkern misslokalisiert (Strässer et al., 2002). Dabei verhindert der THO-Komplex die Bildung von RNA-DNA-Hybriden, den sogenannten „R-loops“. Das könnte bedeuten, dass der THO-Komplex für eine schnelle Transkriptionselongation wichtig ist. In einer weiteren Veröffentlichung wurde durch, ,nuclear run on“ Experimente gezeigt, dass der THO-Komplex an der Herstellung der HSP104 mRNA beteiligt ist, aber nicht Yra1, Gbp2 oder Hrb1 (Saguez et al., 2008). Diese Ergebnisse geben einen ersten Hinweis darauf, dass sich die Zusammensetzung der Stress-spezifischen mRNPs von der regulärer mRNPs unterscheidet (Abbildung 11).

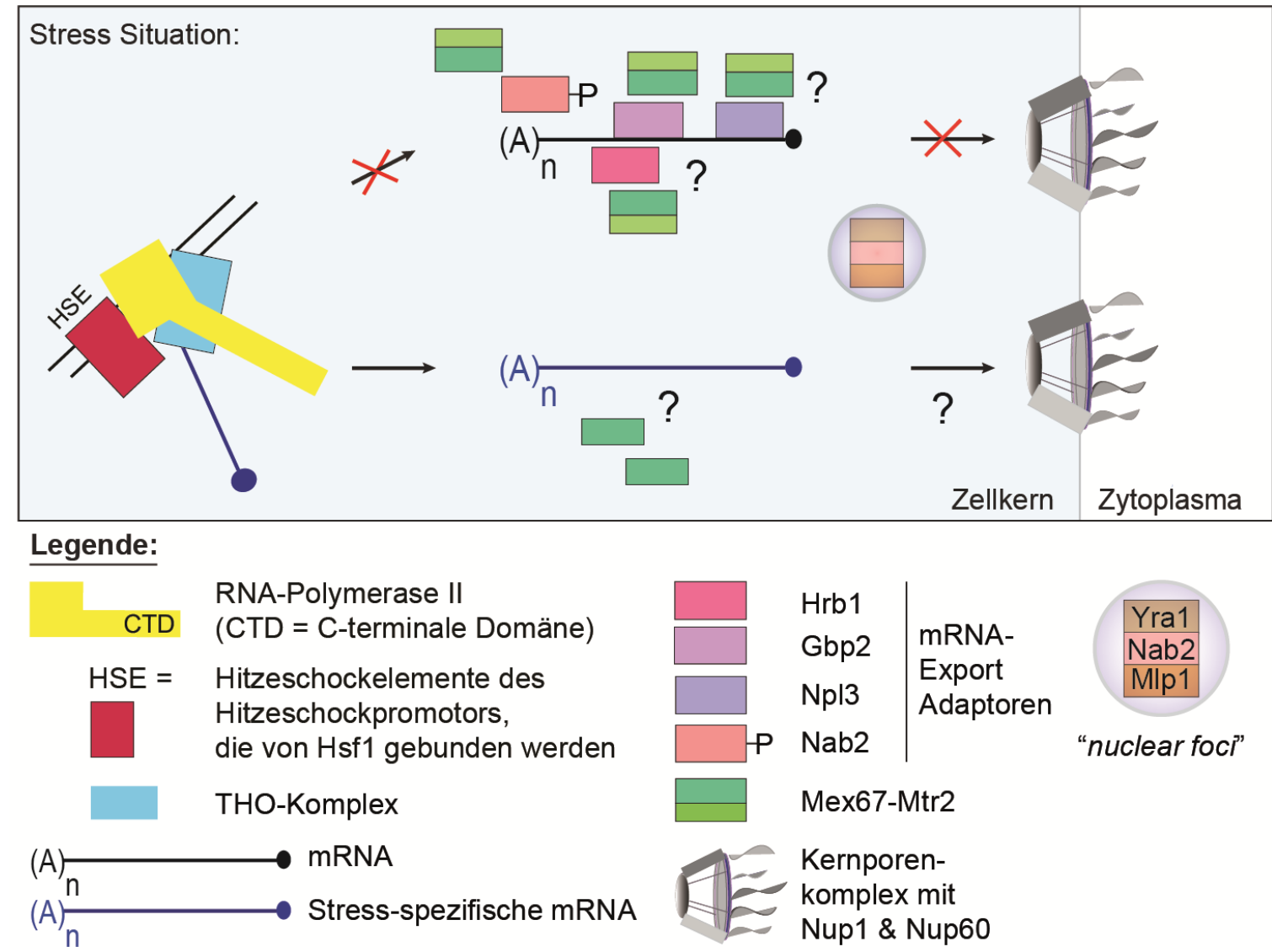

Abbildung 11: Der mRNA-Export bei zellulärem Stress. Während die poly(A)+RNA im Zellkern zurïckgehalten wird, findet ein Export der Stress-spezifischen mRNAs statt. Die einzelnen Proteine sind in der Legende unterhalb der grafischen Darstellung aufgeführt. Die Fragezeichen kennzeichnen unbekannte Mechanismen. 


\subsubsection{Die Translation von Stress-spezifischen mRNAs bei Stress}

Die Translation von Stress-spezifischen mRNAs ist weitesgehend unklar. Während unter normalen Wachstumsbedingungen die Translationsinitiation von den Initiationsfaktoren (eIFs) und unterstützenden Proteinen wie der RNA-Helikase Ded1 abhängig ist, konnten während des Hitzestresses diese Faktoren in zwei Kategorien eingeteilt werden, die Hitzestress-resistenten Faktoren (z. B. eIF-1, 1A, 2) und die Hitzestress-sensitiven Faktoren (wie z. B. eIF-2B, 3, 4G, 5, Ded1) (Wallace et al., 2015). Die Hitzestress-sensitiven Faktoren lokalisieren in ,stress granules“, während die Hitzestress-resistenten Faktoren der Translation von Stress-spezifischen mRNAs zur Verfügung stehen. In vitro Translationsexperimente konnten bereits zeigen, dass ein Zusammenbau des AUG-assoziierten Translationsinitiationskomplexes möglich ist, bei mRNAs ohne Kappenstruktur und ohne die Faktoren eIF-2B/3/4A/4B/4G/4E, wenn eine ,poly(A) leader sequence“ in der 5'-UTR der mRNA vorhanden ist (Shirokikh und Spirin, 2008). Dieser poly(A)-vermittelte Initiationsmechanismus könnte eine Kappen-unabhängige Translation der HitzestressmRNAs erklären (Barnes et al., 1995; Gerstel et al., 1992; Rhoads und Lamphear, 1995; Wallace et al., 2015). Die Eliminierung der oben genannten Initiationsfaktoren könnte durch eine Stress-sensitive Aggregation dieser Faktoren erreicht werden, um die Translation der regulären mRNAs zu inhibieren (Wallace et al., 2015).

\subsubsection{5 „Processing bodies“ und „stress granules”}

Im Zytoplasma werden die regulären mRNAs in ,processing-bodies“ (PBs oder „P-bodies“) oder in ,stress granules“ (SGs) gespeichert und können somit nicht mehr translatiert werden (Anderson und Kedersha, 2006; Buchan und Parker, 2009). Nach der Stresssituation können diese mRNAs entweder abgebaut oder dem Translationskomplex zurückgeführt werden (Decker und Parker, 2012). Zusätzlich bilden sich hochmolekulare Aggregate, die aus Proteinen und Chaperonen bestehen (Wallace et al., 2015) (Abbildung 12). PBs und SGs sind in allen Eukaryoten konserviert und PBs enthalten vorrangig Proteine des mRNAAbbaus und SGs beinhalten hauptsächlich Proteine der Translationsinitiation (Decker und Parker, 2012). Es handelt sich um dynamische und nicht-membrangebundene Organellenähnliche Strukturen, die in ihren Interaktionen und Komplexen derzeit noch nicht vollständig verstanden sind (Walters et al., 2015). 
„P-bodies“ (PBs) werden als Abbau- und Speicherort für nicht-translatierte mRNAs beschrieben (Sheth und Parker, 2003). Sie existieren bereits unter normalen Wachstumsbedingungen, werden jedoch durch verschiedene Arten von Stress verstärkt und führen zur Inhibierung der Translationsinitiation (Hoyle et al., 2007; Teixeira et al., 2005). Die vollständige Proteinkomposition ist noch nicht komplett aufgeklärt, aber es wurden bereits verschiedene RNA-abbauende Enzyme identifiziert, wie z. B. der „,decapping“Komplex Dcp1/Dcp2, der „,decapping“-Aktiviator Lsm1-7, ein Topoisomerase IIassoziiertes Protein Pat1, eine DExD/H-Box Helikase 1 Dhh1, Edc3 und die 5'-3'-Exonuklease Xrn1 (Sheth und Parker, 2003). Zudem können PBs auch den Ccr4/Pop2/Not-Deadenylasekomplex, mRNAs sowie Proteine des "nonsens mediated decay" (NMD) enthalten (Decker und Parker, 2012). PBs sind dynamische Komplexe in der Zelle (Parker und Sheth, 2007), die mRNAs entweder dem Abbau oder der Translation nach überstandener Stresssituation zuführen können (Brengues et al., 2005). Vorzugsweise werden mRNAs, die für ribosomale Proteine codieren, wieder translatiert, während andere abgebaut werden (Arribere et al., 2011).

„Stress granules“ (SGs) sind Aggregate, in denen translational reprimierte mRNPs im Zytoplasma nach induziertem Stress, u. a. Glukosemangel, Hitzeschock oder Ethanolstress gespeichert werden (Grousl et al., 2009; Hoyle et al., 2007; Kato et al., 2011). Man vermutet, dass in SGs vorrangig mRNAs, die sich im Translationsinitiationskomplex befinden, gespeichert werden (Simpson und Ashe, 2012). In höheren Eukaryoten befinden sich die 40S-ribosomale Untereinheiten sowie eine Palette an Translationsinitiationsfaktoren in den SGs (Anderson und Kedersha, 2006). In Hefe-SGs ist die Proteinkomposition flexibler und abhängig von der Stressart und der Dauer des Stresses. So beinhalten beispielsweise SGs, die durch Glukosemangel induziert wurden, kein eIF3 oder ribosomale Untereinheiten (Buchan et al., 2008; Hoyle et al., 2007), während eIF3 oder eIF4G in Hitzestress- oder Ethanolstress-induzierten SGs gefunden wurden (Grousl et al., 2009; Kato et al., 2011). Zudem wurde gezeigt, dass bei hohem Hitzeschock die SGs u. a. eEF3 und eEF1B $\gamma 2$ sowie die Terminationsfaktoren eRF1 und eRF3 beinhalten (Grousl et al., 2013). 


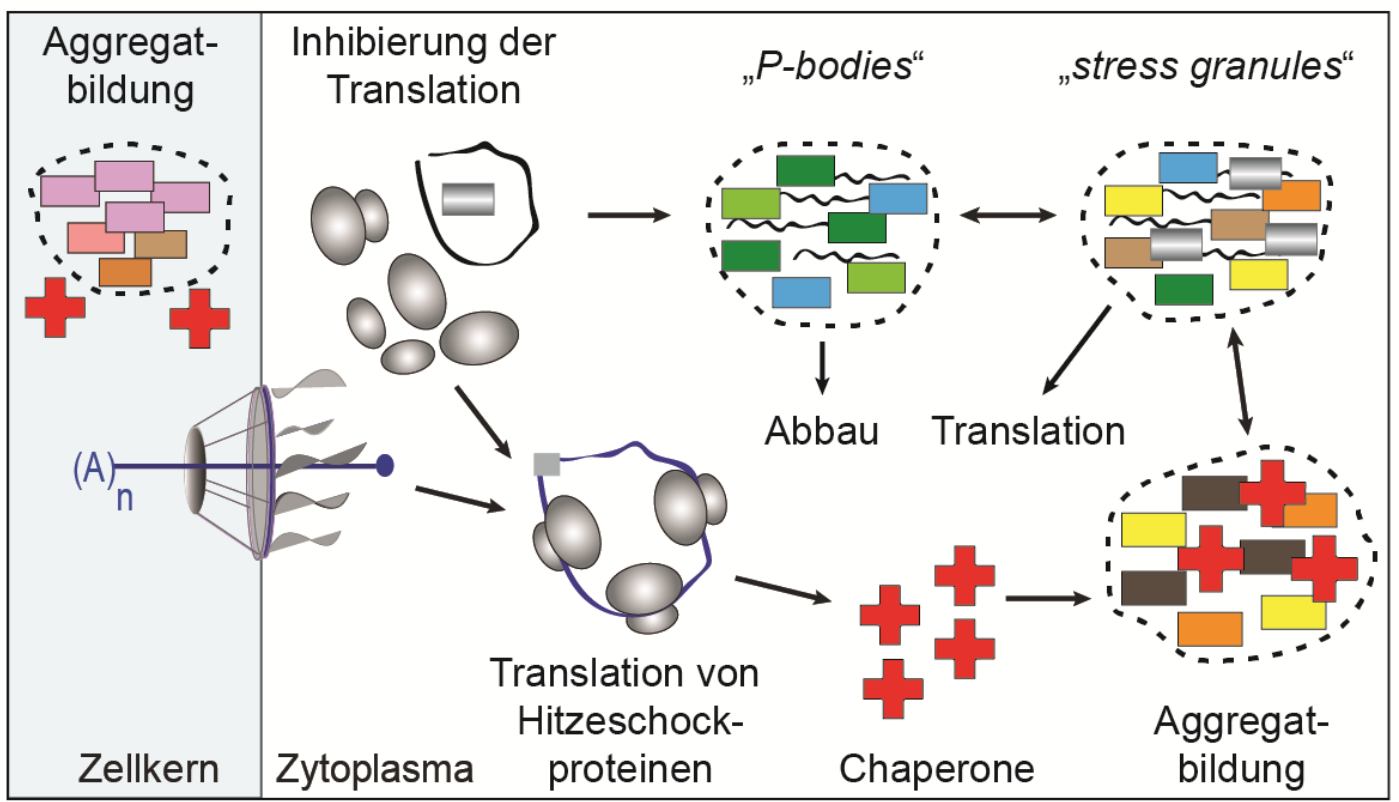

Abbildung 12: Die zytoplasmatische RNA-Biologie bei Stressbedingungen. Stress-spezifische mRNAs werden in das Zytoplasma transportiert und translatiert. Dabei handelt es sich überwiegend um Hitzeschockproteine (Hsps), die als Chaperone fungieren. Gleichzeitig findet eine Inhibierung der Translation von Haushaltstranskripten statt. Diese mRNAs werden in dieser Zeit vorwiegend in „P-bodies“ oder in ,stress granules“ gespeichert und können nach der akuten Stresssituation entweder abgebaut oder wieder translatiert werden. Zusätzlich bilden sich hochmolekulare Aggregate, die aus Proteinen bestehen und Chaperone beinhalten. Modell adaptiert nach (Wallace et al., 2015).

PBs und SGs sind beträchtliche Multiprotein-Komplexe, weshalb Hitzeschockproteine eine Rolle in deren Aufbau oder Abbau spielen könnten (Abbildung 12). Tatsächlich besitzen eine Anzahl von PB/SG-Komponenten Glutamin-reiche Prion-ähnliche Domänen, die eine potentielle Rekrutierungsregion für die Hsp104 und Hsp70-Maschinerie besitzen (Decker et al., 2007). Neuste Ergebnisse zeigen, dass die Hsp70- und Hsp104-Chaperone wichtig für die Auflösung der SGs und PBs nach Stress sind (Cherkasov et al., 2013; Wallace et al., 2015; Walters et al., 2015). Dabei konnte gezeigt werden, dass Proteine die sich in hochmolekularen Aggregaten befinden, nach Stress nicht abgebaut werden, sondern wieder funktionell eingesetzt werden. So zeigen die Autoren, dass Proteine, die während des Stresses im Zellkern in Aggregaten gespeichert werden, wie Ett1 und Gbp2, nach überstandenem Hitzestress aber wieder ihre normale Funktion übernehmen können (Wallace et al., 2015). Normalerweise markiert die Ubiquitinligase San1 falschgefaltete Proteine im Zellkern, sodass sie dem Abbau zugeführt werden (Fredrickson et al., 2013). Doch die Superaggregate von Ett1 und Gbp2 wurden nach überstandenem Stress wieder vollständig löslich, ohne dass die Proteine abgebaut wurden (Wallace et al., 2015). Eukaryotische Zellen bedienen sich also zweier Mechanismen, um die Translation während des zellulären Stresses zu steuern, zum einen durch eine Blockade des Exportes der mRNAs im Zellkern und zum 
anderen durch das Abziehen der zytoplasmatischen mRNAs von den Ribosomen und deren Speicherung in subzellulären granulären Strukturen.

\subsection{Zielsetzung der vorliegenden Arbeit}

Unter normalen Wachstumsbedingungen werden die mRNA-Adaptoren Np13, Gbp2, Hrb1 und Nab2 co-transkriptional zu unterschiedlichen Zeitpunkten auf die prä-mRNA geladen (Hector et al., 2002; Hurt et al., 2004; Lei et al., 2001). Durch Bindung mit dem mRNAExportrezeptor Mex67-Mtr2 werden die gereiften und prozessierten mRNPs in das Zytoplasma transportiert. Im Zytoplasma dissoziieren der mRNA-Exportrezeptor Mex67Mtr2 und das poly $(\mathrm{A})^{+}$-bindende Protein Nab2 direkt an der Zellkernpore durch Dbp5 und dessen Co-Faktoren und werden umgehend wieder in den Zellkern transportiert (Lund und Guthrie, 2005; Tran et al., 2007). Die SR-Proteine bleiben an der regulären mRNA assoziiert und können im Translationskomplex nachgewiesen werden (Baierlein et al., 2013; Windgassen et al., 2004). Durch den Importrezeptor Mtr10 werden sie vom Translationskomplex abgelöst und wieder in den Zellkern transportiert (Hacker und Krebber, 2004; Senger et al., 1998; Windgassen und Krebber, 2003).

Bei zellulärem Stress ändert sich der mRNA-Transportmechanismus (Saavedra et al., 1997). Es findet eine Akkumulation der regulären Transkripte im Zellkern statt (Saavedra et al., 1996; Tani et al., 1996). Dabei dissoziieren die Proteine Npl3 und Nab2 von der poly(A) ${ }^{+}$RNA (Carmody et al., 2010; Krebber et al., 1999). Was aber mit den mRNAAdaptoren Hrb1 und Gbp2 im Zellkern geschieht und ob sie mit dem mRNA-Exportrezeptor Mex67-Mtr2 bei Stress an die poly(A) ${ }^{+}$RNA gebunden bleiben, ist derzeit noch nicht bekannt. Aus diesem Grund soll im ersten Teil der Arbeit die Fragestellung untersucht werden, ob alle mRNA-Adaptoren und Mex67 selbst von der poly(A) RNA im Zellkern dissoziieren. Es stellt sich weiterhin die Frage, ob die mRNA-Adaptoren beim Ablösen von der poly $(\mathrm{A})^{+} \mathrm{RNA}$ weiterhin mit dem mRNA-Exportrezeptor gebunden bleiben, oder ob sie ebenfalls voneinander dissoziieren. Deshalb soll die Interaktion der Adaptoren mit dem Exportrezeptor Mex67-Mtr2 bei Stress analysiert werden.

Außerdem lokalisieren Nab2, Yra1 und Mlp1 bei Stress in „nuclear foci“ im Zellkern (Carmody et al., 2010), während Gbp2 in Super-Aggregaten ebenfalls im Zellkern gespeichert wird (Wallace et al., 2015). Bei Npl3 konnte gezeigt werden, dass es frei in der Zelle diffundiert (Krebber et al., 1999). 
Dabei ergibt sich die Fragestellung, wodurch es zur Lokalisationsänderung der Adaptorproteine bei Stress kommt und ob die mRNA-Adaptoren durch posttranslationale Modifikationen verändert werden.

Um eine schnelle Stressantwort zu gewährleisten, findet ein schneller und gerichteter Export der Stress-spezifischen mRNAs in das Zytoplasma statt, doch wie genau dieser durchgeführt wird, ist zurzeit unbekannt. Deshalb soll im zweiten Teil der Arbeit der Export der Stressspezifischen mRNAs bei Hitze- und Salzstress, genauer untersucht werden. Es konnte bereits gezeigt werden, dass Mex67, Rat7 und Rip1 am Export der Stress-spezifischen mRNAs beteiligt sind (Hurt et al., 2000; Saavedra et al., 1997). Doch weiterhin ist zu klären, wie Mex67 die Stress-spezifischen mRNAs in das Zytoplasma exportiert und ob Mex67 gemeinsam mit Mtr2 als heterodimerer Exportrezeptor funktioniert.

Es ist auch zurzeit noch nicht bekannt, ob die mRNA-Adaptoren Gbp2 oder Hrb1 am Export der Stress-spezifischen Transkripte beteiligt sind. Bisherige Modelle zeigen, dass Mex67 auf Adaptoren angewiesen ist, die den Kontakt zwischen mRNA und Exportrezeptor herstellen. Hierzu soll untersucht werden, ob alle bekannten Adaptoren für den Export von Stressspezifischen Transkripten erforderlich sind. Es könnten zudem noch weitere unbekannte Faktoren für den Export der Stress-spezifischen mRNAs notwendig sein. Deshalb werden die Stress-spezifischen mRNPs mit Hilfe einer Haarnadelstruktur des MS2 Bakteriophagen und dessen assoziiertem Protein MS2CP (,MS2 coating protein“) zur Analyse der interagierenden Proteine an einer Stress-spezifische mRNA aufgereinigt.

In weiteren Fragestellungen soll untersucht werden, ob die Stress-spezifischen Transkripte bei akutem Stress ebenfalls qualitätskontrolliert werden, oder ob nicht-prozessierte StressmRNAs in das Zytoplasma gelangen. Dabei stellt sich die Frage, wie die Zelle zwischen Stress-spezifischer mRNA und regulärer mRNA bei Stress unterscheidet. Da sich scheinbar die Zusammensetzung der Stress-spezifischen mRNPs von den regulären mRNPs unterscheidet, stellt sich die Frage, wie Mex67-Mtr2 die Stress-spezifischen mRNPs in das Zytoplasma exportiert und ob es am Kernporenkomplex durch Dbp5 und dessen CoFaktoren abgelöst wird. 


\section{Material und Methoden}

\subsection{Geräte und Programme}

Tabelle 1: Verwendete Geräte

\begin{tabular}{|c|c|c|}
\hline Gerät & Model & Hersteller \\
\hline $\begin{array}{l}\text { Agarose } \\
\text { Geldokumentations- } \\
\text { system }\end{array}$ & INTAS UV System & $\begin{array}{l}\text { INTAS GmbH } \\
\text { Göttingen/Deutschland }\end{array}$ \\
\hline Chemilumineszenzgerät & Fusion SL $3500 \mathrm{WL}$ & $\begin{array}{l}\text { Peqlab; } \\
\text { Erlangen/Deutschland }\end{array}$ \\
\hline $\begin{array}{l}\text { Dichtegradienten- } \\
\text { Fraktionierungssystem }\end{array}$ & $\begin{array}{l}\text { Foxy Jr Fraktionierer; } \\
\text { Optical Unit Type 11; } \\
\text { Absorptionsmonitor Model UA-6 }\end{array}$ & $\begin{array}{l}\text { Teledyne Isco; } \\
\text { Lincoln, Nebraska/USA }\end{array}$ \\
\hline Dichtegradienten Former & Gradientmaster 108 & $\begin{array}{l}\text { BioComp Instruments; } \\
\text { Fredericton/Kanada }\end{array}$ \\
\hline Elektroblotter & $\begin{array}{l}\text { PerfectBlue Semi-Dry } \\
\text { Elektroblotter, Sedec M }\end{array}$ & $\begin{array}{l}\text { Peqlab } \\
\text { Erlangen/Deutschland }\end{array}$ \\
\hline Fluoreszenzmikroskop & $\begin{array}{l}\text { Leica DMI6000B } \\
\text { mit der Kamera LEICA } \\
\text { DFC360FX }\end{array}$ & $\begin{array}{l}\text { Leica, } \\
\text { Wetzlar/Deutschland }\end{array}$ \\
\hline Lichtmikroskop & Leitz Biomed Typ 020-507-010 & $\begin{array}{l}\text { Leitz, } \\
\text { Wetzlar/Deutschland }\end{array}$ \\
\hline PhosphoImager & PhosphoImager FLA-3000 & $\begin{array}{l}\text { FUJIFILM Europe } \\
\text { GmbH, } \\
\text { Düsseldorf/Deutschland }\end{array}$ \\
\hline Photometer & BioPhotometer & $\begin{array}{l}\text { Eppendorf AG } \\
\text { Hamburg/Deutschland }\end{array}$ \\
\hline Probenfraktionierer & ÄKTA ${ }^{\mathrm{TM}}$ purifier & $\begin{array}{l}\text { GE Healthcare; } \\
\text { Uppsala/Schweden }\end{array}$ \\
\hline Q-RT-PCR Gerät & Rotor Gene Q & $\begin{array}{l}\text { Qiagen, } \\
\text { Hilden/Deutschland }\end{array}$ \\
\hline Spektrophotometer & NanoDrop2000 & $\begin{array}{l}\text { Thermo Scientific } \\
\text { Schwerte/Deutschland }\end{array}$ \\
\hline Sonifizierer & Sonifier-Cell-Disrupter S-250A & $\begin{array}{l}\text { Branson Ultrasonics } \\
\text { Dietzenbach/Deutschland }\end{array}$ \\
\hline Szintillationszähler & LS1701 & $\begin{array}{l}\text { Beckman Coulter, } \\
\text { Krefeld/Deutschland }\end{array}$ \\
\hline Tetradenmikroskop & Nikon Eclipse E400 & $\begin{array}{l}\text { Nikon, } \\
\text { Düsseldorf/Deutschland }\end{array}$ \\
\hline Thermocycler & MyCycler Thermocycler & $\begin{array}{l}\text { BioRad } \\
\text { München/Deutschland }\end{array}$ \\
\hline UV-Crosslinker & Bio-Link BLX-E365 & $\begin{array}{l}\text { Vilber Lourmat } \\
\text { Eberhardzell/Deutschlan }\end{array}$ \\
\hline
\end{tabular}




\begin{tabular}{|l|l|l|}
\hline & & $\mathrm{d}$ \\
\hline Wasserentsalzungssystem & Milli-Q Wasseraufreinigung & $\begin{array}{l}\text { Millipore } \\
\text { Eschborn/Deutschland }\end{array}$ \\
\hline \multirow{3}{*}{ X-Ray Film Prozessor } & Optimax & $\begin{array}{l}\text { PROTEC } \\
\text { Oberstenfeld/ } \\
\text { Deutschland }\end{array}$ \\
\hline \multirow{2}{*}{ Zählkammer } & Neubauer & $\begin{array}{l}\text { Carl Roth GmbH } \\
\text { Karlsruhe/Deutschland }\end{array}$ \\
\hline \multirow{5}{*}{ Zentrifugen } & FastPrep-24 & $\begin{array}{l}\text { MP Biomedicals; } \\
\text { Illkirch/Frankreich }\end{array}$ \\
\cline { 2 - 3 } & $\begin{array}{l}\text { Heraeus Pico 21 } \\
\text { Mikrozentrifuge }\end{array}$ & $\begin{array}{l}\text { Thermo Scientific; } \\
\text { Schwerte/Deutschland }\end{array}$ \\
\cline { 2 - 3 } & $\begin{array}{l}\text { Heraeus Fresco 21 } \\
\text { Kühlmikrozentrifuge }\end{array}$ & $\begin{array}{l}\text { Thermo Scientific; } \\
\text { Schwerte/Deutschland }\end{array}$ \\
\cline { 2 - 3 } & $\begin{array}{l}\text { Heraeus Multifuge X3R mit } \\
\text { Ausschwingrotor TX-750 oder } \\
\text { mit }\end{array}$ & $\begin{array}{l}\text { Thermo Scientific; } \\
\text { Schwerte/Deutschland }\end{array}$ \\
\cline { 2 - 3 } & $\begin{array}{l}\text { Fiberlite F15-8x50cy } \\
\text { Festwinkelrotor }\end{array}$ & $\begin{array}{l}\text { Ultrazentrifuge WX Ultra 80 } \\
\text { mit dem TH-641 Rotor }\end{array}$ \\
\cline { 2 - 3 } & $\begin{array}{l}\text { Thermo Scientific; } \\
\text { Schwerte/Deutschland }\end{array}$ \\
\hline
\end{tabular}

Tabelle 2: Verwendete Software

\begin{tabular}{|l|l|l|}
\hline Anwendung & Software & Hersteller \\
\hline Bildbearbeitungsprogramme & $\begin{array}{l}\text { Adobe Photoshop CS6; } \\
\text { Adobe Illustrator CS6 }\end{array}$ & $\begin{array}{l}\text { Adobe Systems; } \\
\text { San Jose/USA }\end{array}$ \\
\hline DNA Sequenz Editor & ApE plasmid editor & $\begin{array}{l}\text { von M. Wayne Davis } \\
\text { University of Utah /USA }\end{array}$ \\
\hline $\begin{array}{l}\text { Bildquantifizierung und } \\
\text { Quantifizierung } \\
\text { Chemilumineszenzsignalen }\end{array}$ & Fiji 1.48s Java 1.6.0_65 & $\begin{array}{l}\text { von W. Rasband } \\
\text { NIH/USA }\end{array}$ \\
\hline $\begin{array}{l}\text { Quantifizierungsprogramm } \\
\text { für } \\
\text { Chemilumineszenzsignale }\end{array}$ & Bio-1D & $\begin{array}{l}\text { Peqlab } \\
\text { Erlangen/Germany }\end{array}$ \\
\hline Statistische Auswertung & Microsoft Excel 2010 & $\begin{array}{l}\text { Microsoft Corporation } \\
\text { Redmond/USA }\end{array}$ \\
\hline Textbearbeitung & Microsoft Word 2010 & $\begin{array}{l}\text { Microsoft Corporation } \\
\text { Redmond/USA }\end{array}$ \\
\hline $\begin{array}{l}\text { Aufnahme von } \\
\text { Mikroskopiebilder }\end{array}$ & LAS AF 2.7.3.9 & $\begin{array}{l}\text { Leica } \\
\text { Wetzlar/Germany }\end{array}$ \\
\hline Bildquantifizierung & AIDA Image Analyzer v.4.22 & $\begin{array}{l}\text { FUJIFILM Europe } \\
\text { GmbH, } \\
\text { Düsseldorf/Deutschland }\end{array}$ \\
\hline
\end{tabular}




\subsection{Chemikalien und Verbrauchsmaterialien}

Tabelle 3: Allgemeine Chemikalien und Verbrauchsmaterialen

\begin{tabular}{|c|c|}
\hline Chemikalie & Bezugsquelle \\
\hline Acetonitril & Carl Roth, Karlsruhe/Deutschland \\
\hline Agarose NEEO Ultra-Qualität & Carl Roth, Karlsruhe/Deutschland \\
\hline Amersham Hybond ${ }^{\mathrm{TM}}-\mathrm{N}^{+}$Membran & GE Healthcare, Freiburg/Deutschland \\
\hline $\begin{array}{l}\text { Amersham Protran } 0.45 \mu \mathrm{m} \text { Nitrocellulose- } \\
\text { Membran }\end{array}$ & GE Healthcare, Freiburg/Deutschland \\
\hline Ammoniumhydrogencarbonat & Carl Roth, Karlsruhe/Deutschland \\
\hline „,blocking reagent“ & $\begin{array}{l}\text { Roche Diagnostics, } \\
\text { Mannheim/Deutschland }\end{array}$ \\
\hline „Bacto Yeast nitrogen base w/o amino acids" & Becton Dickinson, Franklin Lakes/USA \\
\hline „Coomassie brilliant blue“ $\mathrm{R}-250$ & Sigma-Aldrich, Taufkirchen/Deutschland \\
\hline $\begin{array}{l}\text { "Complete" EDTA-freie-Protease Inhibitor- } \\
\text { Cocktail }\end{array}$ & $\begin{array}{l}\text { Roche Diagnostics, } \\
\text { Mannheim/Deutschland }\end{array}$ \\
\hline $\begin{array}{l}\text { Disodium 3-(4-methoxyspiro }\{1,2 \text {-dioxetane- } \\
3,2^{\prime} \quad-\left(5^{\prime} \quad \text {-chloro }\right) \text { tricyclo } \\
[3.3 .1 .13,7] \text { decan }\}-4 \text {-yl }) \text { phenyl phosphate } \\
\text { (CSPD) }\end{array}$ & $\begin{array}{l}\text { Roche Diagnostics, } \\
\text { Mannheim/Deutschland }\end{array}$ \\
\hline Cy3-Oligo-dT 50 & Biospring, Frankfurt/Deutschland \\
\hline Cycloheximid & Sigma-Aldrich, Taufkirchen/Deutschland \\
\hline Dithiothreitol (DTT) & AppliChem, München/Deutschland \\
\hline Desoxyribonukleosidtriphosphat (dNTP) & $\begin{array}{l}\text { Thermo Fisher Scientific, } \\
\text { Schwerte/Deutschland }\end{array}$ \\
\hline 5-Fluoroorotsäure (5-FOA) & ApolloScientific, Stockport/UK \\
\hline Formaldehyd Lösung (ACS reagent) & Sigma-Aldrich, Taufkirchen/Deutschland \\
\hline Formamid, deionisiert & AppliChem, München/Deutschland \\
\hline Galaktose $(\mathrm{D}(+))$ & Acros Organics, Geel/Belgien \\
\hline GFP-Trap_A® & $\begin{array}{l}\text { ChromoTek, Planegg- } \\
\text { Martinsried/Deutschland }\end{array}$ \\
\hline Glasperlen $0,2-0,5 \mathrm{~mm}$ & Carl Roth, Karlsruhe/Deutschland \\
\hline Glutathion Sepharose 4B & GE Healthcare, Freiburg/Deutschland \\
\hline Hefeextrakt & Carl Roth, Karlsruhe/Deutschland \\
\hline Hoechst 33342 & Sigma-Aldrich, Taufkirchen/Deutschland \\
\hline Hybond $\mathrm{N}^{+}$Nylon Membran & GE Healthcare, Freiburg/Deutschland \\
\hline IgG-Sepharose ${ }^{\mathrm{TM}} 6$ “fast flow” Beads & GE Healthcare, Freiburg/Deutschland \\
\hline Isopropyl- $\beta$-D-thiogalactopyranosid (IPTG) & Carl Roth (Karlsruhe/Germany) \\
\hline
\end{tabular}




\begin{tabular}{|l|l|}
\hline Iodoacetamide & AppliChem, München/Deutschland \\
\hline Ni-NTA Agarose & Qiagen, Hilden/Deutschland \\
\hline Nitrocellulose Membran (Protran®) & PerkinElmer, Waltham/USA \\
\hline Objektträger 12 Loch & $\begin{array}{l}\text { Thermo Fisher Scientific, } \\
\text { Schwerte/Deutschland }\end{array}$ \\
\hline$\gamma$-[P'3]-ATP (SRP-301) & $\begin{array}{l}\text { Hartmann Analytik, } \\
\text { Braunschweig/Deutschland }\end{array}$ \\
\hline $\begin{array}{l}\text { Phenol/Chloroform/Isoamylalkohol (P/C/I) } \\
(25: 24: 1)\end{array}$ & Carl Roth (Karlsruhe/Germany) \\
\hline Chloroform/Isoamylalkohol (C/I) & Carl Roth (Karlsruhe/Germany) \\
\hline $\begin{array}{l}\text { Polyallomer Röhrchen für die } \\
\text { Ultrazentrifugation }\end{array}$ & Beckman Coulter, Krefeld/Deutschland \\
\hline Poly-L-Lysin Hydrobromid & Sigma-Aldrich, Taufkirchen/Deutschland \\
\hline Protein G Sepharose & Applied Biosystems, Foster City/USA \\
\hline Protino Ni-IDA Resin & Machery und Nagel Düren/Deutschland \\
\hline Rotiphorese Gel 30 (37.5:1) & Carl Roth, Karlsruhe/Deutschland \\
\hline Saccharose & Carl Roth, Karlsruhe/Deutschland \\
\hline Heringssperma-DNA & Sigma-Aldrich, Taufkrichen/Deutschland \\
\hline tRNAs & Sigma-Aldrich, Taufkrichen/Deutschland \\
\hline Trypsin & $\begin{array}{l}\text { SERVA Electrophoresis GmbH, } \\
\text { Heidelberg/Deutschland }\end{array}$ \\
\hline Whatman ,blotting paper“ 0.8 mm & Hahnemühle FineArt Kassel/Deutschland \\
\hline
\end{tabular}

Tabelle 4: Verwendete Antikörper in folgenden Anwendungen: Western-Blot Analysen (WB), Northern-Blot Analysen (NB) oder Fluoreszenz in situ Hybridisierungsexperimenten (FISH)

\begin{tabular}{|l|l|l|}
\hline Antikörper & $\begin{array}{l}\text { Verdünnung } \\
\text { in WB }\end{array}$ & Bezugsquelle \\
\hline HRP-Anti-Maus (Ziege) & $1: 10000$ & Dianova, Hamburg/Deutschland \\
\hline HRP-Anti-Kaninchen (Ziege) & $1: 10000$ & Dianova, Hamburg/Deutschland \\
\hline Anti-Aco1 (Kaninchen) & $1: 2000$ & $\begin{array}{l}\text { Schenkung von Prof. Dr. R. Lill, } \\
\text { Marburg/Deutschland }\end{array}$ \\
\hline Anti-Dbp5 (Kaninchen) & $1: 1000$ & $\begin{array}{l}\text { Peptide Specialty Laboratories } \\
\text { Heidelberg/Deutschland }\end{array}$ \\
\hline $\begin{array}{l}\text { Anti-Digoxigenin-AP-Fab } \\
\text { (Schaf) }\end{array}$ & $1: 10000$ (NB) & Roche Mannheim/Deutschland \\
\hline $\begin{array}{l}\text { Anti-Digoxigenin Fab-FITC } \\
\text { (Schaf) }\end{array}$ & $1: 200$ (FISH) & Roche Mannheim/Deutschland \\
\hline
\end{tabular}




\begin{tabular}{|l|l|l|}
\hline Anti-Hem15 (Kaninchen) & $1: 7000$ & $\begin{array}{l}\text { Schenkung von Prof. Dr. R. Lill, } \\
\text { Marburg/Deutschland }\end{array}$ \\
\hline Anti-His (Kaninchen) & $1: 500$ & Santa Cruz, Heidelberg/Deutschland \\
\hline Anti-GFP (Kaninchen) & $1: 1000$ & Santa Cruz, Heidelberg/Deutschland \\
\hline Anti-GFP (Maus) & $1: 5000$ & $\begin{array}{l}\text { Pierce, Thermo Fisher Scientific, } \\
\text { Schwerte/Deutschland }\end{array}$ \\
\hline Anti-GST (Kaninchen) & $1: 1000$ & Santa Cruz, Heidelberg/Deutschland \\
\hline $\begin{array}{l}\text { Anti-Kaninchen-IgG } \\
\text { AlexaFluor®488 (Ziege) }\end{array}$ & $1: 250$ (FISH) & Invitrogen, Frankfurt/Deutschland \\
\hline Anti-Mex67 (Kaninchen) & $1: 50000$ & $\begin{array}{l}\text { Schenkung von Prof. Dr. C. Dargemont, } \\
\text { Paris/Frankreich }\end{array}$ \\
\hline Anti-myc (Kaninchen) & $1: 1000$ & Santa Cruz, Heidelberg/Deutschland \\
\hline Anti-myc (Maus) & $1: 1000$ & Santa Cruz, Heidelberg/Deutschland \\
\hline Anti-Np13 (Kaninchen) & $1: 7000$ & Abteilung von Prof. Dr. H. Krebber \\
\hline Anti-Por1 (Kaninchen) & $1: 2000$ & $\begin{array}{l}\text { Schenkung von Prof. Dr. R. Lill, } \\
\text { Marburg/Deutschland }\end{array}$ \\
\hline Anti-Rpl35 (Kaninchen) & $1: 5000$ & $\begin{array}{l}\text { Schenkung von Prof. Dr. M. Seedorf, } \\
\text { Heidelberg/ Deutschland }\end{array}$ \\
\hline $\begin{array}{l}\text { Anti-Rps3 (Kaninchen) } \\
\text { (Peptidantikörper) }\end{array}$ & $1: 1000$ & $\begin{array}{l}\text { Davids Biotechnologie } \\
\text { Regensburg/Deutschland }\end{array}$ \\
\hline Anti-Zwf1 (Kaninchen) & $1: 4000$ & $\begin{array}{l}\text { Schenkung von Prof. Dr. R. Lill, } \\
\text { Marburg/Deutschland }\end{array}$ \\
\hline Alle aufgelisend Angendet wurden,
\end{tabular}

Alle aufgelisteten Antikörper (Tabelle 4), die für Western-Blot Analysen verwendet wurden, wurden in $2 \%(\mathrm{w} / \mathrm{v})$ Magermilchpulver in 1x TBST verdünnt. Die Verdünnungen wurden bei $-20^{\circ} \mathrm{C}$ zur mehrfachen Nutzung gelagert.

Tabelle 5: Größenstandards

\begin{tabular}{|l|l|l|}
\hline Größenstandard & Anwendung & Hersteller \\
\hline $\begin{array}{l}\text { „Lambda“ DNA/EcoRI+HindIII } \\
\text { Marker }\end{array}$ & Agarosegele & $\begin{array}{l}\text { Thermo Scientific, } \\
\text { Schwerte/Deutschland }\end{array}$ \\
\hline $\begin{array}{l}\text { „PageRuler Prestained Protein } \\
\text { Ladder" }\end{array}$ & SDS-PAGE & $\begin{array}{l}\text { Thermo Scientific, } \\
\text { Schwerte/Deutschland }\end{array}$ \\
\hline $\begin{array}{l}\text { „PageRuler Unstained Protein } \\
\text { Ladder" }\end{array}$ & SDS-PAGE & $\begin{array}{l}\text { Thermo Scientific, } \\
\text { Schwerte/Deutschland }\end{array}$ \\
\hline
\end{tabular}

Tabelle 6: Kits

\begin{tabular}{|l|l|}
\hline Kit & Bezugsquelle \\
\hline $\begin{array}{l}\text { Amersham ECL Prime Western Blot } \\
\text { Detektionskit }\end{array}$ & GE Healthcare, Freiburg/Deutschland \\
\hline DIG RNA ,labeling mix“, 10x konz. & Roche, Mannheim/Deutschland \\
\hline GoTaq® qPCR Master Mix & Promega, Madison, WI/USA \\
\hline
\end{tabular}




\begin{tabular}{|l|l|}
\hline NucleoBond PC 100 & Machery-Nagel, Düren/Deutschland \\
\hline NucleoSpin Plasmid & Machery-Nagel, Düren/Deutschland \\
\hline NucleoSpin RNA & Machery-Nagel, Düren/Deutschland \\
\hline peqGOLD Gel Extraktion Kit & Peqlab, Erlangen/Deutschland \\
\hline pGEM@-T Vektor System & Promega Corporation, Madison/USA \\
\hline
\end{tabular}

Tabelle 7: Enzymatische Produkte

\begin{tabular}{|c|c|}
\hline Enzym & Bezugsquelle \\
\hline $\begin{array}{l}\text { "Maxima Reverse Transkriptase", } \\
\text { "Random Hexamer Primer" }\end{array}$ & $\begin{array}{l}\text { Thermo Fisher Scientific, } \\
\text { Schwerte/Deutschland }\end{array}$ \\
\hline „Dream Taq“ DNA Polymerase & $\begin{array}{l}\text { Thermo Fisher Scientific, } \\
\text { Schwerte/Deutschland }\end{array}$ \\
\hline $\begin{array}{l}\text { FastAP Thermosensitive Alkaline } \\
\text { Phosphatase }\end{array}$ & $\begin{array}{l}\text { Thermo Fisher Scientific, } \\
\text { Schwerte/Deutschland }\end{array}$ \\
\hline $\begin{array}{l}\text { Phusion }{ }^{\circledR} \text { "High-Fidelity” DNA } \\
\text { Polymerase }\end{array}$ & New England Biolabs, Beverly/USA \\
\hline RiboLock® RNase Inhibitor & $\begin{array}{l}\text { Thermo Fisher Scientific, } \\
\text { Schwerte/Deutschland }\end{array}$ \\
\hline Restriktionsenzyme & $\begin{array}{l}\text { Thermo Fisher Scientific, } \\
\text { Schwerte/Deutschland }\end{array}$ \\
\hline Restriktionsenzyme & New England Biolabs Frankfurt/Deutschland \\
\hline RNase A & AppliChem, München, Deutschland \\
\hline T4-DNA Ligase & $\begin{array}{l}\text { Thermo Fisher Scientific, } \\
\text { Schwerte/Deutschland }\end{array}$ \\
\hline T5-Exonuklease & New England Biolabs Frankfurt/Deutschland \\
\hline T7-RNA Polymerase & $\begin{array}{l}\text { Thermo Fisher Scientific, } \\
\text { Schwerte/Deutschland }\end{array}$ \\
\hline Taq DNA Ligase & New England Biolabs Frankfurt/Deutschland \\
\hline Velocity® DNA Polymerase & Bioline, Luckenwalde/Deutschland \\
\hline Zymolase® 20T & Seikagaku corporation, Tokyo/Japan \\
\hline
\end{tabular}

Weitere Chemikalien und Verbrauchsmaterialien wurden von den folgenden Firmen bezogen, oder vorher aufgeführt: Apollo Scientific Limited (Derbyshire, England), AppliChem (München, Deutschland), B. Braun (Melsungen, Deutschland), BD Biosciences (Heidelberg, Deutschland), Carl Roth (Karlsruhe, Deutschland), Difco (Detroit, USA), Fisher Scientific (Nidderau, Deutschland), GE Healthcare (Freiburg, Deutschland) Invitrogen (Frankfurt am Main, Deutschland), Merck (Darmstadt, Deutschland), New England Biolabs (Frankfurt am Main, Deutschland), OMNILAB GmbH (Bremen, Deutschland), Promega (Mannheim, Deutschland), Roche Diagnostics (Mannheim, Deutschland), Sarstedt (Nürnbrecht, Deutschland), 
Serva Feinbiochemika (Heidelberg, Deutschland), Sigma-Aldrich (München, Deutschland), Thermo Scientific (Schwerte, Deutschland), Th.Geyer (Renningen, Deutschland) sowie VWR International (Darmstadt, Deutschland).

\subsection{Stämme}

\subsubsection{Escherichia coli Stämme}

Für die Amplifikation von Plasmid-DNA wurde der Bakterienstamm DH5 $\alpha$ mit dem Genotyp (supE44 lacZU169 (80lacM15) hsdR17 recAl endA1 gyrA69 thi-1 relA149) verwendet. Für die Herstellung von rekombinanten Proteinen wurde die E. coli-Stämme BL21 (DE3) mit dem Genotyp ( $F$-, $d c m$, ompT, $h s d S(r B-m B-$ ), gald (DE3)) und Rosetta 2 (DE3) mit dem Genotyp ( $F$ - ompT gal dcm lon hsdSB ( $r B$-, $m B-$-) $\lambda(\mathrm{DE} 3) p R A R E 2(C a m R)$ ) verwendet.

\subsubsection{Saccharomyces cerevisiae Stämme}

Tabelle 8: Hefestämme, die in dieser Studie verwendet wurden.

\begin{tabular}{|c|c|c|}
\hline $\begin{array}{l}\text { Stamm- } \\
\text { nummer }\end{array}$ & Genotyp & Quelle \\
\hline HKY35 & MATа ura3-52 leu2 $\Delta 1$ trp $1 \Delta 63$ & $\begin{array}{l}\text { Prof. Dr. F. Winston, } \\
\text { Boston, USA }\end{array}$ \\
\hline HKY36 & 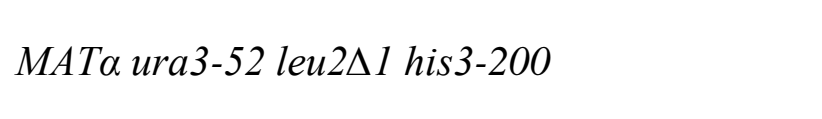 & $\begin{array}{l}\text { Prof. Dr. F. Winston, } \\
\text { Boston, USA }\end{array}$ \\
\hline HKY124 & 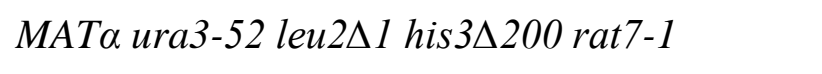 & (Gorsch et al., 1995) \\
\hline HKY157 & $\begin{array}{l}\text { MATa ura3 leu } 2 \text { his } 3 \text { ade npl3::HIS3 } \\
+p \text { CEN URA3 NPL3-myc }\end{array}$ & (Shen et al., 1998) \\
\hline HKY168 & $\begin{array}{l}\text { MATa ura3 leu2 trpl his3 lys } 2 \text { ade } 2 \text { ade } 8 \\
\text { gbp2::HIS }\end{array}$ & (Hackmann et al., 2014) \\
\hline HKY194 & $\begin{array}{l}\text { MATa ura3 leu2 trp1 his3 lys } 2 \text { ade2 ade3 } \\
\text { hrb1::HIS3 }\end{array}$ & (Shen et al., 1998) \\
\hline HKY280 & $\begin{array}{l}\text { MATа ura3-52 leu2 trp1 pep4-3 pre1-407prbl- } \\
1122 \text { PAB1-GFP:KAN }\end{array}$ & (Zenklusen et al., 2001) \\
\hline HKY294 & 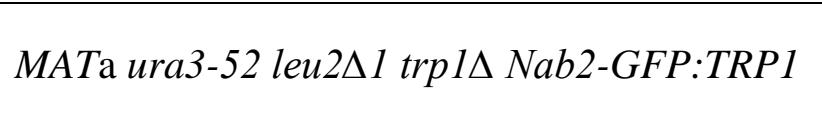 & $\begin{array}{l}\text { Prof. Dr. H. Krebber, } \\
\text { Göttingen, Deutschland }\end{array}$ \\
\hline HKY298 & $\begin{array}{l}\text { MATa ura3 } 30 \text { leu } 2 \Delta 0 \text { his } 3 \Delta 1 \text { lys } 2 \Delta 0 \\
\text { hrb1::kanMX4 }\end{array}$ & Euroscarf \\
\hline
\end{tabular}


Material und Methoden

\begin{tabular}{|c|c|c|}
\hline HKY307 & $\begin{array}{l}\text { MATa ura3 leu2 his3 ade } 2 \text { trpl yral::HIS3 } \\
+p \text { CEN URA3 YRA1 }\end{array}$ & (Sträßer et al., 2000) \\
\hline HKY369 & 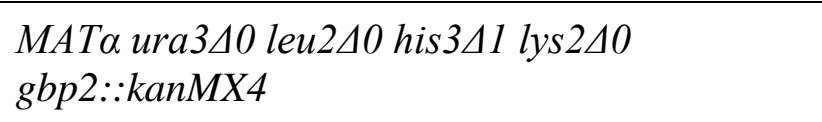 & Euroscarf \\
\hline HKY380 & $\begin{array}{l}\text { MATa } \operatorname{ura} 3 \Delta 0 \text { leu } 2 \Delta 0 \text { his } 3 \Delta 1 \text { met } 15 \Delta 0 \\
\text { npl3::kanMX4 }\end{array}$ & Euroscarf \\
\hline HKY381 & MATa ura $3 \Delta 0$ leu $2 \Delta 0$ his $3 \Delta 1$ lys $2 \Delta 0$ & Euroscarf \\
\hline HKY428 & MAT $\alpha$ ura3-52 leu2 21 his34200 mtr4-G677D & (Hackmann et al., 2014) \\
\hline HKY643 & $\begin{array}{l}\text { MAT } \alpha \text { ura3 leu } 2 \text { trp1 his } 3 \text { ade } 2 \text { mex } 67: \because H I S 3 \\
+p \text { CEN URA3 MEX67 }\end{array}$ & (Segref et al., 1997) \\
\hline HKY644 & $\begin{array}{l}\text { MAT } \alpha \text { ura3 leu } 2 \text { trp1 his } 3 \text { ade } 2 \text { mex67::HIS3 } \\
+p \text { CEN LEU2 mex67-5 }\end{array}$ & (Segref et al., 1997) \\
\hline HKY682 & 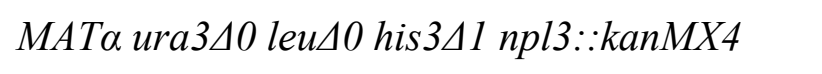 & (Hackmann et al., 2014) \\
\hline HKY820 & 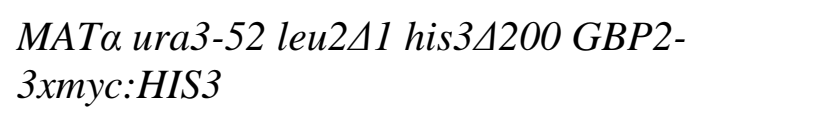 & (Hackmann et al., 2014) \\
\hline HKY821 & 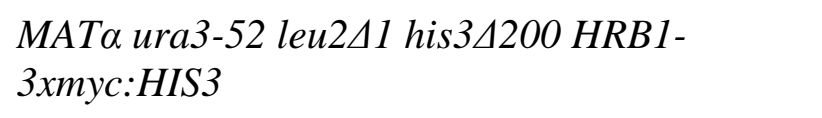 & (Hackmann et al., 2014) \\
\hline HKY891 & $\begin{array}{l}\text { MATa ura3 leu2 his3 lys } 2 \text { mtr } 2:: k a n M X 4 \\
+p \text { CEN TRP } 1 \text { mtr } 2-21+p \text { CEN URA3 MTR2 }\end{array}$ & (Baßler et al., 2001) \\
\hline HKY892 & $\begin{array}{l}\text { MATa ura3 leu2 his3 lys } 2 \text { mtr } 2:: \text { kanMX4 } \\
+p \text { CEN TRP1 mtr2-33 + p CEN URA3 MTR2 }\end{array}$ & (Baßler et al., 2001) \\
\hline HKY931 & MATа ura $3 \Delta 0$ leu $2 \Delta 0$ his $3 \Delta 1 \operatorname{trp} 1:: k a n M X 4$ & (Baierlein et al., 2013) \\
\hline HKY1028 & $\begin{array}{l}\text { MATa leu } 2 \Delta 0 \text { his } 3 \Delta 1 \text { lys } 2 \Delta 0 \text { ura } 3 \Delta 0 \\
\text { rrp6::kanMX4 }\end{array}$ & Euroscarf \\
\hline HKY1115 & $\begin{array}{l}\text { MATa ura3 leu2A nab2::HIS3 + p CEN URA3 } \\
n a b 2 \Delta N\end{array}$ & (Marfatia et al., 2003) \\
\hline HKY1203 & $\begin{array}{l}\text { MATa his } 3 \Delta 1 \text { leu } 2 \Delta 0 \text { met } 15 \Delta 0 \text { ura3 } 30 \text { lys } 2 \Delta 0 \\
\text { hrb1::HIS3 rrp6::kanMX4 }\end{array}$ & (Hackmann et al., 2014) \\
\hline HKY1204 & 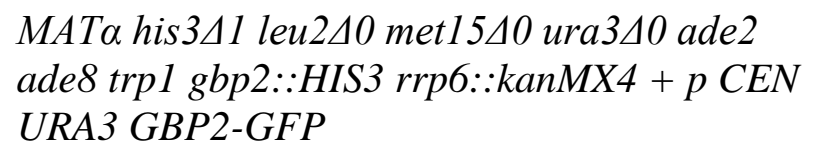 & (Hackmann et al., 2014) \\
\hline HKY1264 & $\begin{array}{l}\text { MATa ura3 } \Delta 0 \text { leu } 2 \Delta 0 \text { his } 3 \Delta 1 \text { met } 15 \Delta 0 \\
\text { hsp12::kanMX4 }\end{array}$ & Euroscarf \\
\hline HKY1266 & 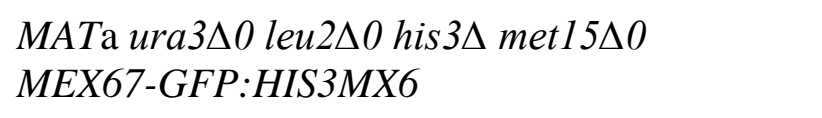 & Invitrogen \\
\hline
\end{tabular}




\begin{tabular}{|c|c|c|}
\hline HKY1310 & $\begin{array}{l}\text { MATa leu2 } \triangle 0 \text { his } 3 \Delta 1 \text { lys } 2 \Delta 0 \text { ura } 3 \Delta 0 \\
\text { rrp6::kanMX4 npl3kan::MX4 }\end{array}$ & $\begin{array}{l}\text { Prof. Dr. H. Krebber, } \\
\text { Göttingen, Deutschland }\end{array}$ \\
\hline HKY1345 & $\begin{array}{l}\text { MATa ura } 3 \Delta 0 \text { leu } 2 \Delta 0 \text { his } 3 \Delta \text { met } 15 \Delta 0 \\
\text { ADH5-GFP:HIS } 3 M X 6\end{array}$ & Invitrogen \\
\hline HKY1458 & $\begin{array}{l}\text { MATa ura } 3 \Delta 0 \text { leu } 2 \Delta 0 \text { his } 3 \Delta \text { met } 15 \Delta 0 \\
\text { Yral-GFP:HIS3MX6 }\end{array}$ & Invitrogen \\
\hline HKY1475 & $\begin{array}{l}\text { MATa ura } 3 \Delta 0 \text { leu } 2 \Delta 0 \text { his } 3 \Delta \text { met } 15 \Delta 0 \\
\text { NAB2-GFP:HIS3MX6 }\end{array}$ & Invitrogen \\
\hline HKY1506 & $\begin{array}{l}\text { MATa ura3 leu2 } 2 \text { his } 3 \triangle 1 \text { nab2::HIS3 } \\
\text { rrp6::kanMX4+ p CEN URA3 nab } 2 \Delta N\end{array}$ & $\begin{array}{l}\text { Prof. Dr. H. Krebber, } \\
\text { Göttingen, Deutschland }\end{array}$ \\
\hline HKY1571 & $\begin{array}{l}\text { MATa ura3 } 30 \text { leu } 2 \Delta 0 \text { mtr4-G677D CYC1- } \\
\text { GFP:HIS3MХ6 }\end{array}$ & $\begin{array}{l}\text { Prof. Dr. H. Krebber, } \\
\text { Göttingen, Deutschland }\end{array}$ \\
\hline HKY1572 & $\begin{array}{l}\text { MATa ura3 } 30 \text { leu } 2 \Delta 0 \text { rrp6::kanMX4 CYC1- } \\
\text { GFP:HIS3MX6 }\end{array}$ & $\begin{array}{l}\text { Prof. Dr. H. Krebber, } \\
\text { Göttingen, Deutschland }\end{array}$ \\
\hline
\end{tabular}

\subsection{Plasmide}

Plasmide, die in Tabelle 9 aufgelistet sind, wurden in einer Konzentration von $1 \mu \mathrm{g} / \mu 1 \mathrm{mit}$ deionisierten Nuklease-freiem Wasser gelöst und bei $-20{ }^{\circ} \mathrm{C}$ gelagert.

Tabelle 9: Plasmide, die in dieser Studie verwendet wurden.

\begin{tabular}{l|l|l}
\hline $\begin{array}{l}\text { Plasmid- } \\
\text { nummer }\end{array}$ & Charakteristika & Quelle \\
\hline pHK12 & CEN URA3 PADH-NLS-NES-GFP-GFP & (Taura et al., 1998) \\
\hline pHK20 & CEN LEU2 MEX67-GFP & (Segref et al., 1997) \\
\hline pHK87 & CEN LEU2 & (Sikorski und Hieter, 1989) \\
\hline pHK88 & CEN URA3 & (Sikorski und Hieter, 1989) \\
\hline pHK103 & $2 \mu$ LEU2 & (Christianson et al., 1992) \\
\hline pHK104 & $2 \mu$ URA3 & (Christianson et al., 1992) \\
\hline pHK469 & NAB2-GFP:TRP1 & $\begin{array}{l}\text { Prof. Dr. H. Krebber, } \\
\text { Göttingen, Deutschland }\end{array}$ \\
\hline pHK367 & CEN URA3 GBP2-GFP & (Windgassen und Krebber, \\
\hline pHK418 & CEN LEU2 GFP-NPL3
\end{tabular}




\begin{tabular}{|c|c|c|}
\hline pHK477 & CEN TRP yral-1 & (Sträßer et al., 2000) \\
\hline pHK571 & $2 \mu U R A 3 G B P 2-S 15 A-G F P$ & (Hackmann et al., 2014) \\
\hline pHK765 & CEN URA3 GFP-NPL3 & (Hackmann et al., 2014) \\
\hline pHK779 & CEN URA3 9xMYC-NPL3 & (Hackmann et al., 2014) \\
\hline pHK892 & CEN URA3 PADHPRP17-GFP & (Hackmann et al., 2014) \\
\hline pHK927 & CEN URA3 PADHHRB1-GFP & (Hackmann et al., 2014) \\
\hline pHK1276 & ampR GST-NPL3 & (Baierlein et al., 2013) \\
\hline pHK1279 & kanR PT7:HIS6:MTR2 & Diese Arbeit \\
\hline pHK1372 & ampR PTRC:HIS:TEV:MTR2:MEX67 & (Yao et al., 2007) \\
\hline pHK1373 & $\begin{array}{l}\text { ampR } \\
\text { PTRC:HIS:TEV:MTR2:mex67loopKR }>A A\end{array}$ & (Yao et al., 2007) \\
\hline pHK1374 & $\begin{array}{l}\text { ampR PTRC:HIS:TEV:MTR2:mex67-409- } \\
\text { 435aaK343E }\end{array}$ & (Yao et al., 2007) \\
\hline pHK1376 & CEN LEU2 mex67 409-435aa & (Yao et al., 2007) \\
\hline pHK1377 & $\begin{array}{l}\text { CEN LEU2 mex67loopKR>AA }(K 415 A, \\
K 416 A, K 419 A, K 424 A, R 426 A, R 427 A)\end{array}$ & (Yao et al., 2007) \\
\hline pHK1417 & CEN URA3 PHSP12-HSP12-2xMSIIL & Diese Arbeit \\
\hline pHK1418 & CEN URA3 PMET25-ACT1-2xMSIIL & Diese Arbeit \\
\hline pHK1419 & $\begin{array}{l}\text { CEN HIS PMET25-MS2CP-HIS6-TEV- } \\
\text { PROTA }\end{array}$ & Diese Arbeit \\
\hline pHK1443 & CEN URA3 PCYC1-CYC1-GFP & Diese Arbeit \\
\hline pHK1444 & CEN URA3 PHSP12-CYC1-GFP & Diese Arbeit \\
\hline pHK1445 & CEN URA3 PHSP12-HSP12-GFP & Diese Arbeit \\
\hline
\end{tabular}

\subsection{Oligonukleotide}

Die verwendeten Oligonukleotide sind in Tabelle 8 aufgelistet und von Sigma-Aldrich (München, Deutschland) bezogen. Die Proben wurden mit Nuklease freiem Wasser zu einer Konzentration von $100 \mu \mathrm{M}$ gelöst und bei $-20{ }^{\circ} \mathrm{C}$ gelagert.

Tabelle 10: Verwendete Oligonukleotide

\begin{tabular}{l|l|l|l}
\hline $\begin{array}{l}\text { Oligo- } \\
\text { nummer }\end{array}$ & Sequenz & Zielgen & Merkmale \\
\hline HK818 & 5'-CCACTATAACACCCGATGAGG-3' & IDP3 forward & \\
\hline HK819 & 5'-GGCAAACTAAGGTTACAGTTTAGC-3' & IDP3 reverse & \\
\hline HK1002 & 5'-TGCTAAGGCTGTCGGTAAGG-3' & $T D H 1$ forward & \\
\hline HK1003 & 5'-TCAGAGGAGACAACGGCATC-3' & $T D H 1$ reverse & \\
\hline HK1066 & 5'-GGTTGAACGGTTCTTGTATGGC-3' & $A D H 1$ forward & \\
\hline HK1067 & 5'-CCAAAGAACCTAGACCACCAGC-3' & $A D H 1$ reverse & \\
\hline
\end{tabular}




\begin{tabular}{|c|c|c|c|}
\hline HK1326 & $\begin{array}{l}5^{\prime} \text {-cgcgcgaattc } \\
\text { ATGGATTCTGGTATGTTCTAGC-3' }\end{array}$ & $A C T 1$ forward & $\begin{array}{l}\text { EcoRI- } \\
\text { Schnittstelle }\end{array}$ \\
\hline HK1327 & $\begin{array}{l}\text { 5'-cgcggacgtc } \\
\text { TTAGAAACACTTGTGGTGAACG-3, }\end{array}$ & $A C T 1$ reverse & $\begin{array}{l}\text { AatII- } \\
\text { Schnittstelle }\end{array}$ \\
\hline HK1332 & $\begin{array}{l}\text { 5'-cgccgccatatg } \\
\text { ATGAACACCAATAGTAATACTATGG-3' }\end{array}$ & MTR2 forward & $\begin{array}{l}\text { NdeI- } \\
\text { Schnittstelle }\end{array}$ \\
\hline HK1333 & $\begin{array}{l}\text { 5'-gccgcgctcgag } \\
\text { CTAAATTTTTAGCAGAGAATCCT-3' }\end{array}$ & $M T R 2$ reverse & $\begin{array}{l}\text { XhoI- } \\
\text { Schnittstelle }\end{array}$ \\
\hline HK1350 & 5'-cgcgcCAATTGgtccaggtggagtgcgatttg-3' & $P_{H S P 12}$ forward & $\begin{array}{l}\text { MfeI- } \\
\text { Schnittstelle }\end{array}$ \\
\hline HK1358 & $\begin{array}{l}\text { 5'-taatagactcactataggg } \\
\text { GGGTTCATTAGATCCTAAGGT-3' }\end{array}$ & $M S I I L$ reverse & $\begin{array}{l}\text { XhoI- } \\
\text { Schnittstelle }\end{array}$ \\
\hline HK1359 & 5'-GGTACAACCTATTCATGTGTTGC-3' & SSA4 forward & \\
\hline HK1360 & $\begin{array}{l}\text { 5'-taatacgactcactataggg } \\
\text { TACCGGTTTACCTCCC-3' }\end{array}$ & SSA4 reverse & $\begin{array}{l}\text { T7- } \\
\text { Promotor }\end{array}$ \\
\hline HK1361 & 5'-GGAGCCAGTGGAAAAAGTTTTG-3' & SSA4 forward & \\
\hline HK1362 & $\begin{array}{l}\text { 5'-taatacgactcactataggg } \\
\text { ATCAACTTTGTCATAA-3' }\end{array}$ & $S S A 4$ reverse & $\begin{array}{l}\text { T7- } \\
\text { Promotor }\end{array}$ \\
\hline HK1363 & 5'-CGGTGAAAAAGCTTCTGAAGC-3' & HSP12 forward & \\
\hline HK1364 & $\begin{array}{l}\text { 5'-taatacgactcactataggg } \\
\text { TTACTTCTTGGTTGGG-3' }\end{array}$ & $H S P 12$ reverse & $\begin{array}{l}\text { T7- } \\
\text { Promotor }\end{array}$ \\
\hline HK1473 & 5'-CACCTACGCTGACAACCAACC-3' & SSA4 forward & \\
\hline HK1474 & 5'-САТССТСТTCACССАССТТСТСС-3' & SSA4 reverse & \\
\hline HK1475 & $\begin{array}{l}\text { 5'-CAAGGATAACGCTGAAGGTCAAGG- } \\
\text { 3' }\end{array}$ & HSP12 forward & \\
\hline HK1476 & 5'-CTTCTTGGTTGGGTCTTCTTCACC-3' & $H S P 12$ reverse & \\
\hline HK1477 & 5'-GTTGAAAGTCGTGGTTCCTGGTG-3' & HSP26 forward & \\
\hline HK1478 & 5'-CTGCTCTCCTTGACCTTGACCTTG-3' & $H S P 26$ reverse & \\
\hline HK1494 & 5'-AAAGCACCGTTTCCCGTCC-3' & $\begin{array}{l}5 S r R N A \\
\text { forward }\end{array}$ & \\
\hline HK1495 & 5'-CACTACACTACTCGGTCAGGCT-3' & $5 S$ rRNA reverse & \\
\hline HK1509 & 5'-CGGGCTCTGGAAGAATGTGTTG-3' & GRE3 forward & \\
\hline HK1510 & 5'-GAGGACCGAAGGAGGAGTAAGC-3' & GRE3 reverse & \\
\hline HK1511 & 5'-GTCTTCCTCCGCTCAAACTTCC-3' & SSA1 forward & \\
\hline HK1512 & 5'-GAACAGCAGCACCGTAAGCAAC-3' & SSA1 reverse & \\
\hline HK1513 & 5'-GCCCAATGGCAAGAAACCAAAC-3' & $E D C 2$ forward & \\
\hline HK1514 & 5'-CCATCGTTGCCTTATCGTCCTC-3' & $E D C 2$ reverse & \\
\hline HK1523 & 5'-CCCGGGgagcaccaccaccaccaccacG-3' & HIS forward & $\begin{array}{l}\text { XmaI- } \\
\text { Schnittstelle }\end{array}$ \\
\hline HK1524 & 5'-GCTAGCgtggtggtggtggtggtgctcC-3' & $H I S$ reverse & $\begin{array}{l}\text { NheI- } \\
\text { Schnittstelle }\end{array}$ \\
\hline HK1853 & $\begin{array}{l}\text { 5'-CCAGCTGCAGGCGGCGGCCGCT } \\
\text { TAGCAGCCGGATCCTTTG-3' }\end{array}$ & $G F P$ reverse & $\begin{array}{l}\text { NotI- } \\
\text { Schnittstelle }\end{array}$ \\
\hline HK1955 & 5'-GGTGAGCCAGGTATCGGTAAGAC-3' & HSP104 forward & \\
\hline HK1956 & 5'-CCGATGACCTTCAATTGGCCTC-3' & HSP104 reverse & \\
\hline HK1957 & 5'-caaaagctggagctccgga & $P_{H S P 12}$ forward & Kpn2I- \\
\hline
\end{tabular}




\begin{tabular}{l|l|l|l}
\hline & AGTGCGATTTGTTCGTTATATGC-3' & & Schnittstelle \\
\hline HK1958 & $\begin{array}{l}\text { 5'- } \\
\text { CGACGTCCCATGGCCATTCGAATTCTT } \\
\text { ACTTCTTGGTTGGGTCTTC-3' }\end{array}$ & HSP12 reverse & $\begin{array}{l}\text { EcoRI- } \\
\text { Schnittstelle }\end{array}$ \\
\hline HK1959 & $\begin{array}{l}\text { 5'-acaaagctggagctccgga } \\
\text { CAGGGTAACAGTATTGATGTAATC-3' }\end{array}$ & P $_{C Y C l}$ forward & $\begin{array}{l}\text { Kpn2I- } \\
\text { Schnittstelle }\end{array}$ \\
\hline HK1961 & $\begin{array}{l}\text { 5'-CCGGCCTTGAATTCAGTCAT } \\
\text { GCTAGCTGTTGTATTTAGTTTTTTTGT } \\
\text { TTTGAGT-3' }\end{array}$ & CYC1 reverse & $\begin{array}{l}\text { NheI- } \\
\text { Schnittstelle }\end{array}$ \\
\hline
\end{tabular}

\subsection{Kultivierung von Stämmen}

Vor der Verwendung der Nährmedien wurden diese autoklaviert. Bei hitzelabilen Komponenten wie Antibiotika wurden diese vor ihrer Verwendung sterilfiltriert und anschließend dem autoklavierten Medium zugesetzt. Zur Herstellung von Festmedium wurde dem entsprechenden Flüssigmedium für E. coli 1,5\% (w/v) bzw. für Hefe 1,8\% (w/v) Agar zugesetzt.

\subsubsection{Kultivierung von $E$. coli Zellen}

Für die Kultivierung von Bakterien wurde das Luria-Bertani (LB)-Medium nach dem Standardprotokoll verwendet (Sambrook et al., 1989). Zur Selektion von Plasmid-kodierten Resistenzen wurden den Medien Ampicillin in einer Endkonzentration von $100 \mu \mathrm{g} / \mathrm{ml}$ oder Kanamycin mit $30 \mu \mathrm{g} / \mathrm{ml}$ hinzugegeben. Die Kultivierung der E. coli-Stämme erfolgte, sofern nicht anders angegeben, über Nacht bei $37^{\circ} \mathrm{C}$. Flüssigkulturen wurden mit Einzelkolonien von Agarplatten beimpft und in einem Schüttelinkubator bei $160 \mathrm{rpm}$ und $37^{\circ} \mathrm{C}$ inkubiert. Erreichte Zelldichten (Optische Dichte, OD) wurden in einem Spektralphotometer bei einer Wellenlänge von $600 \mathrm{~nm}$ gemessen. Dabei entspricht eine $\mathrm{OD}_{600}$ von eins einem Titer von $2 \times 10^{8}$ Zellen/ml.

LB-Medium ( $\mathrm{pH} \mathrm{7,5):}$

$$
\begin{aligned}
& 1 \%(\mathrm{w} / \mathrm{v}) \text { Pepton } \\
& 0,5 \%(\mathrm{w} / \mathrm{v}) \text { Hefeextrakt } \\
& 1 \%(\mathrm{w} / \mathrm{v}) \mathrm{NaCl}
\end{aligned}
$$


Für die Kultivierung von E. coli Rosetta 2 Zellen wurde das Autoinduktionsmedium (AI-Medium) verwendet zur Expression und Aufreinigung von rekombinanten Proteinen (2.10.4). Dazu wurden Einzelkolonien von Agarplatten in Flüssigkultur gebracht und für $72 \mathrm{~h}$ bei $16^{\circ} \mathrm{C}$ inkubiert.

AI-Medium:

$$
\begin{aligned}
& 11 \mathrm{LB}-\mathrm{Medium} \\
& 1.25 \mathrm{M} \mathrm{K} 2 \mathrm{HPO} 4 \\
& 1.25 \mathrm{M} \mathrm{NaH} 2 \mathrm{PO} 4 \\
& 2.50 \mathrm{M} \mathrm{NH} 4 \mathrm{Cl} \\
& 0.25 \mathrm{M} \mathrm{Na} 2 \mathrm{SO} 4 \\
& 25 \%(\mathrm{v} / \mathrm{v}) \text { Glycerin } \\
& 2.5 \%(\mathrm{w} / \mathrm{v}) \text { Glucose } \\
& 10 \%(\mathrm{w} / \mathrm{v}) \text { Laktose } \\
& 2 \mathrm{M} \mathrm{MgSO} 4
\end{aligned}
$$

\subsubsection{Kultivierung von $S$. cerevisiae}

Die Kultivierung der Hefezellen erfolgte nach den Standardprotokollen (Rose et al., 1990; Sherman, 1991). Die verwendeten Hefestämme wurden standardmäßig bei $25^{\circ} \mathrm{C}$ und mit Hefevollmedium (,yeast extract peptone dextrose medium“; YPD-Medium) kultiviert. Flüssigkulturen wurden mit Einzelkolonien von Agarplatten oder mit Teilen einer Vorkultur beimpft. Übernachtkulturen wurden in einem Schüttelinkubator bei $120 \mathrm{rpm}$ inkubiert. Zelldichten wurden durch das Auszählen mit Hilfe der Neubauer Zählkammer bestimmt. Hefekulturen wurden in einer logarithmischen Wachstumsphase (1-3x $10^{7}$ Zellen/ml) geerntet, bei $4200 \mathrm{x} \mathrm{g}$ und $10 \mathrm{~min}$ zentrifugiert und für nachfolgende Experimente in flüssigem Stickstoff schockgefroren oder frisch verwendet.

$\underline{\text { YPD-Medium (Vollmedium): }}$

$$
\begin{aligned}
& 1 \%(\mathrm{w} / \mathrm{v}) \text { Hefeextrakt } \\
& 2 \%(\mathrm{w} / \mathrm{v}) \text { Pepton } \\
& 2 \%(\mathrm{w} / \mathrm{v}) \text { Glukose }
\end{aligned}
$$


Zur Selektion eines plasmid- oder genomkodierten Markergenes, das eine Stoffwechselauxotrophie des Hefestammes komplettierte, wurde das NährstoffMangelmedium so gewählt, dass es das Produkt des jeweiligen Stoffwechselweges nicht enthielt.

Nährstoff-Mangelmedium:

$$
\begin{aligned}
& 0,17 \%(\mathrm{w} / \mathrm{v}) \text { "Bacto yeast Nitrogen base w/o amino acids" } \\
& 0,51 \%(\mathrm{w} / \mathrm{v}) \text { Ammoniumsulfat } \\
& 0,2 \%(\mathrm{w} / \mathrm{v}) \text { "Yeast synthetic dropout medium supplement" } \\
& 2 \%(\mathrm{w} / \mathrm{v}) \text { Glukose }
\end{aligned}
$$

Zur Negativselektion von URA3-Marker Plasmiden bzw. Positivselektion von Uracilauxotrophen Hefezellen wurden FOA-Agarplatten verwendet. Da Enzyme des UracilSyntheseweges, 5'-Floroorotsäure in das toxische Produkt 5'-Fluorouracil umsetzen, können nur Hefezellen auf FOA-Platten wachsen, die selbst Uracil auxotroph sind und die ein URA3 Gen tragendes Plasmid nicht mehr enthalten. Eine intrazelluläre Anreicherung des toxischen Produktes kann somit nicht entstehen (Boeke et al., 1987). Das Medium wurde sterilfiltriert und dem Agar nach dem Autoklavieren zugesetzt.

FOA-Agarplatten:

$$
\begin{aligned}
& 0,17 \%(\mathrm{w} / \mathrm{v}) \text { "Bacto yeast Nitrogen base w/o amino acids" } \\
& 0,2 \%(\mathrm{w} / \mathrm{v}) \text { "Yeast synthetic dropout medium supplement" } \\
& 0,51 \%(\mathrm{w} / \mathrm{v}) \text { Ammoniumsulfat } \\
& 0,1 \%(\mathrm{w} / \mathrm{v}) 5 \text { '-Fluoroorotsäure (FOA) } \\
& 2 \%(\mathrm{w} / \mathrm{v}) \text { Glukose } \\
& 1,8 \%(\mathrm{w} / \mathrm{v}) \text { Agar }
\end{aligned}
$$

Zur Herstellung diploider Zygoten wurden zwei haploide Hefestämme mit unterschiedlichem Kreuzungstyp auf Agar-Vollmedium und bei $25^{\circ} \mathrm{C}$ kombiniert (Sherman, 1991; Sherman und Hicks, 1991). Darauffolgend wurden die gewachsenen Zellen auf entsprechende Nährstoff-Mangelmediumplatten gestempelt und auf diploide Zellen selektiert. Die gewachsenen diploiden Zellen wurden in Super-Spo Medium (Stickstoffmangel, Acetat als Kohlenstoffquelle) übertragen, für drei bis sieben Tage bei 
$25^{\circ} \mathrm{C}$ rotierend inkubiert und dadurch zum sporulieren angeregt. Nachdem sich Tetraden entwickelt haben wurden diese mit Hilfe des Tetradenmikroskops und eines Mikromanipulators dissektiert. $100 \mu \mathrm{l}$ der Zellsuspension wurde mit $40 \mu \mathrm{g}$ Zymolase inkubiert, bis die Ascuswand verdaut war und die Sporen im Lichtmikroskop sichtbar wurden. Durch waschen der Suspension mit der P-Lösung (2.9.1) wurde die Reaktion gestoppt und die Tetraden wurden auf YPD Platten übertragen. Vier Sporen einer Tetrade konnten auf der YPD Platte vereinzelt werden durch die Verwendung des Mikromanipulators. Nach Inkubation der Platte für zwei bis fünf Tage bei $25^{\circ} \mathrm{C}$ konnten die gereiften Sporen analysiert werden entweder mittels verschiedener NähstoffMangelmediumplatten oder durch die Aufreinigung der chromosomalen DNA und die im Anschluss durchgeführte analytische PCR (2.7.1).

Sporulationsmedium (Super-Spo):

Lösung 1:

$0,5 \%(w / v)$ Hefeextrakt

306 mM Kaliumacetat

Lösung 2:

5 mM Glukose

0,4 mM Adenin

0,7 mM Uracil

0,4 mM Tyrosin

$0,2 \mathrm{mM}$ Histidin

0,3 mM Leucin

0,2 mM Lysin

0,2 mM Tryptophan

0,3 mM Methionin

0,2 mM Arginin

1,2 mM Phenylalanin

5,9 mM Threonin

Nach dem Autoklavieren von Lösung 1 und dem Steril filtrieren von Lösung 2 wurden beide Lösungen im Verhältnis 1:1 zusammengegeben. 


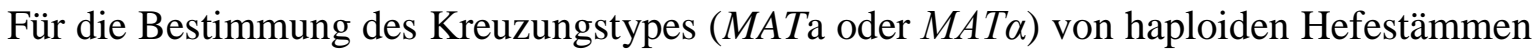
wurden die Zellen auf zwei YPD Platten gestempelt, die jeweils mit einem Rasen von vorgegebenen MATa oder MAT $\alpha$ Teststämmen übersät waren (Sprague, 1991). Nach drei Tagen Wachstum wurden die Zellen auf B-Platten übertragen. Auf den B-Platten können nur Zellen wachsen, die sich mit dem jeweils entgegengesetzten Kreuzungstyp gepaart haben. So ließ sich im Anschluss herausfinden, welchen Kreuzungstyp der haploide Hefestamm besitzt.

B-Platen:

\author{
$0.17 \%(\mathrm{w} / \mathrm{v})$ "Bacto yeast Nitrogen base w/o amino acids" \\ $0.51 \%(\mathrm{w} / \mathrm{v})$ Ammoniumsulfat \\ $0.3 \%(\mathrm{w} / \mathrm{v})$ Agar \\ $2 \%(\mathrm{w} / \mathrm{v})$ Glukose
}

\title{
2.7 Molekularbiologische Methoden
}

\subsubsection{Polymerase-Kettenreaktion}

Die Polymerase-Kettenreaktion (,polymerase chain reaction“, PCR) ist eine Methode zur in vitro Amplifikation eines spezifischen DNA-Abschnittes (Saiki et al., 1988). Dabei katalysiert die hitzestabile DNA-Polymerase die Synthese des neuen, komplementären DNA-Stranges ausgehend von einem synthetisierten Oligonukleotid (Primer) in 5'-3'Richtung über eine Primerverlängerung bis zum anderen Primer. Mit Hilfe dieser Methode können zum einen analytische PCRs mittels der „Dream-Taq“ DNA-Polymerase (von Thermo Scientific) aus Thermus aquaticus (Chien et al., 1976) durchgeführt werden, mit der Plasmide oder genomische DNA (gDNA) überprüft wurden. Und zum anderen wurden DNA-Polymerasen, wie u. a. "Velocity" (von Bioline) oder "Phusion High-Fidelity" (von Thermo Scientific) für Klonierungszwecke von DNA-Fragmenten eingesetzt. Diese Enzyme besitzen eine zusätzliche 3'-5'-Exonuklease-Aktivität und weisen damit eine Korrekturlesefunktion auf (Lundberg et al., 1991). Die Reaktionsansätze variieren für jedes Enzym und wurden nach Angaben des Herstellers gewählt. Die Standardreaktion für die „Dream-Taq“ DNA-Polymerase wird in Tabelle 11 und Tabelle 12 gezeigt. 
Tabelle 11: Standardreaktion für die "Dream Taq" DNA Polymerase.

\begin{tabular}{|l|l|}
\hline Komponenten & Konzentration \\
\hline 10x „Dream Taq“ Puffer & $1 \mathrm{x}$ \\
\hline „Dream Taq“ DNA-Polymerase & $1.25 \mathrm{U}$ \\
\hline $2 \mathrm{mM}$ dNTP-Mix & $0.2 \mathrm{mM}$ \\
\hline $10 \mu \mathrm{M}$ Primer-Mix (forward und reverse, je $100 \mathrm{pmol} / \mu \mathrm{l})$ & $1 \mu \mathrm{M}$ \\
\hline \multirow{2}{*}{ DNA-Matritze } & $0.5 \mu \mathrm{gDNA}$ oder \\
& $10 \mathrm{ng}$ Plasmid-DNA \\
\hline
\end{tabular}

Die Ansätze wurden mit Nuklease-freiem Wasser auf ein Volumen von $50 \mu$ l eingestellt.

Tabelle 12: PCR-Programm für die "Dream Taq" DNA Polymerase.

\begin{tabular}{|l|l|l|}
\hline Schritt & Zeit & Temperatur \\
\hline Initiale Denaturierung & $3 \mathrm{~min}$ & $95^{\circ} \mathrm{C}$ \\
\hline Denaturierung & $30 \mathrm{sec}$ & $95^{\circ} \mathrm{C}$ \\
\hline Hybridisierung & $30 \mathrm{sec}$ & $\mathrm{x}\left(50-60^{\circ} \mathrm{C}\right)$ \\
\hline Elongation & $1 \mathrm{~min} / \mathrm{kb}$ DNA & $72^{\circ} \mathrm{C}$ \\
\hline Finale Elongation & $10 \mathrm{~min}$ & $72^{\circ} \mathrm{C}$ \\
\hline Lagerung & $\infty$ & $8^{\circ} \mathrm{C}$ \\
\hline
\end{tabular}

Die Hybridisierungstemperatur (x) wurde je nach Schmelztemperatur der Primerpaare gewählt.

\subsubsection{Agarose-Gelelektrophorese und DNA-Aufreinigung}

Zur Auftrennung von DNA-Fragmenten wurde eine horizontale Agarose-Gelelektrophorese unter Nutzung des Fluoreszenzfarbstoffes Ethidiumbromid durchgeführt (Sharp et al., 1973). Das in die DNA interkalierende Ethidiumbromid fluoresziert bei Anregung mit UVLicht der Wellenlänge von $254 \mathrm{~nm}$ und kann so die DNA anfärben (Kemp et al., 1989). Die negativ geladenen DNA-Fragmente werden in einem TAE-Agarosegel durch ein elektrisches Feld separiert. Dabei wurden in Abhängigkeit der erwarteten Größen der aufzutrennenden DNA-Fragmente, $0,8-2 \% \quad(\mathrm{w} / \mathrm{v})$ TAE-Agarosegele mit $0,5 \mu \mathrm{g} / \mathrm{ml}$ Ethidiumbromid verwendet. Die zu analysierenden DNA-Lösungen wurden mit 6x DNAProbenpuffer versetzt und in 1x TAE Puffer bei $10 \mathrm{~V} / \mathrm{cm}^{2}$ für $30-60 \mathrm{~min}$ aufgetrennt. Die DNA-Fragmente wurden auf einem UV-Leuchttisch visualisiert und mittels Videodokumentationsanlage festgehalten. Die Größen der DNA-Fragmente wurden anhand eines parallel aufgetragenen DNA-Größenstandards (GeneRuler ${ }^{\mathrm{TM}}$ 100bp DNA-Marker oder „Lambda-DNA EcoRI+HindIII Marker“"von Thermo Scientific) ermittelt. 
$1 \mathrm{x}$ TAE-Puffer $(\mathrm{pH} 8,5)$ :

$$
\begin{aligned}
& 40 \mathrm{mM} \text { Tris/HCl } \\
& 0,1 \% \text { (v/v) Essigsäure } \\
& 1 \mathrm{mM} \text { EDTA }
\end{aligned}
$$

6x DNA-Probenpuffer:

$$
\begin{aligned}
& 10 \mathrm{mM} \text { Tris pH } 7.6 \\
& 60 \%(\mathrm{v} / \mathrm{v}) \text { Glycerin } \\
& 60 \mathrm{mM} \text { EDTA } \\
& 0.03 \%(\mathrm{w} / \mathrm{v}) \text { Bromphenolblau } \\
& 0.03 \%(\mathrm{w} / \mathrm{v}) \text { Xylencyanol }
\end{aligned}
$$

Für die Aufreinigung von spezifischen DNA-Fragmenten wurde eine präparative AgaroseGelelektrophorese durchgeführt. Hierzu wurde die DNA wie beschrieben aufgetrennt bis das DNA-Fragment deutlich separiert war und anschließend aus dem Agarosegel herausgeschnitten. Die Aufreinigung des Gelstückes erfolgte mit dem "peqGOLD Gel Extraktion Kit" (von Peqlab) entsprechend der Angaben des Herstellers. Die auf gereinigte DNA wurde in $30 \mu 1$ Elutionspuffer gelöst und die Konzentration wurde mit dem NanoDrop Spektrophotometer bei $\mathrm{OD}_{260}$ gemessen. Die Lagerung der DNA erfolgte bei $-20{ }^{\circ} \mathrm{C}$.

\subsubsection{Hydrolytische Spaltung von DNA durch Restriktionsendonukleasen}

Eine sequenzspezifische Hydrolyse der DNA (Restriktionsanalyse) erfolgte durch verschiedene Restriktionsendonukleasen des Typs II, diese schneiden DNA sequenzspezifisch an Palindromen. Für die vollständige Spaltung wurden pro $1 \mu \mathrm{g}$ DNA 5 bis $10 \mathrm{U}$ der entsprechenden Endonuklease in den Restriktionsansatz eingebracht und dieser mit Enzym entsprechenden Reaktionspuffer für $1 \mathrm{~h}$ bis über Nacht bei der vom Hersteller empfohlenen Temperatur inkubiert. Die Reaktionsvolumina betrugen im analytischen Maßstab bei Einsatz bis zu $1 \mu \mathrm{g}$ DNA $20 \mu 1$. In präparativen Maßstäben wurden die Volumina entsprechend der eingesetzten DNA-Menge vergrößert.

\subsubsection{Dephosphorylierung von 5'-DNA-Enden}

Um Religationen zu verhindern, wurde linearisierte Vektor-DNA vor dem Einsatz in eine Ligationsreaktion am 5'-Ende dephosphoryliert. Hierzu wurde der Restriktionsansatz nach Beendigung der hydrolytischen Spaltung mit 1 U FastAP thermosensitive Alkaline Phosphatase (von Thermo Scientific) versetzt und nach Angaben des Herstellers für $10 \mathrm{~min}$ 
bei $37{ }^{\circ} \mathrm{C}$ inkubiert. Im Anschluss erfolgte eine Inaktivierung der Reaktion bei $65^{\circ} \mathrm{C}$ für 15 $\min$.

\subsubsection{Ligation von DNA-Fragmenten}

Zur Herstellung rekombinanter Plasmide wurden DNA-Fragmente durch die T4-DNA-Ligase (von Thermo Scientific) mit adäquat restringierter Vektor-DNA kovalent verbunden. Phosphodiester-Bindungen wurden von der T4-DNA-Ligase entweder zwischen kompatiblen kohäsiven oder glatten Enden gebildet. In beiden Fällen wurde die VektorDNA mit einer Endkonzentration von $100 \mathrm{ng} /$ Reaktionsvolumen eingesetzt. Die Konzentration der DNA-Fragmente stand in einem molaren Verhältnis von 2:1 zur VektorDNA. Die Ligation erfolgte in einem Volumen von $10 \mu \mathrm{l}$. Jeweils $2 \mathrm{U}$ der Ligase wurde im mitgelieferten Puffer eingesetzt und die Ligation erfolgte über Nacht bei $16{ }^{\circ} \mathrm{C}$.

\subsection{6 ,Gibson assembly"-Reaktion}

Bei der „Gibson assembly“ Reaktion können mehrere DNA-Fragmente mit überlappenden Enden kovalent in einer isothermischen Ein-Schritt-Reaktion verknüpft werden (Gibson, 2009). In dieser Reaktion werden die folgenden drei Enzyme verwendet, die T5-Exonuklease verdaut die Enden eines DNA-Doppelstrangs teilweise, wodurch ein einzelsträngiger 3'-Überhang eine Hybridisierung der homologen einzelsträngigen Bereiche der DNA-Sequenzen einleitet. Weiterhin wird die „Phusion“ DNA Polymerase (von NEB) mit DNA-Doppelstrang trennenden Eigenschaften verwendet, die während der Synthese eines zweiten DNA-Strangs den vorliegenden Doppelstrang auftrennt und den bestehenden zweiten Strang verdrängt. Eine Taq-DNA Ligase verbindet schließlich kovalent die verbliebenen Lücken miteinander. Das entstandene rekombinante Plasmid kann nun für weitere molekularbiologische Anwendungen verwendet werden. Der Ansatz wurde nach Anleitung von Gibson et al., 2009 und Gibson, 2011 durchgeführt. 
GA-Master Mix:

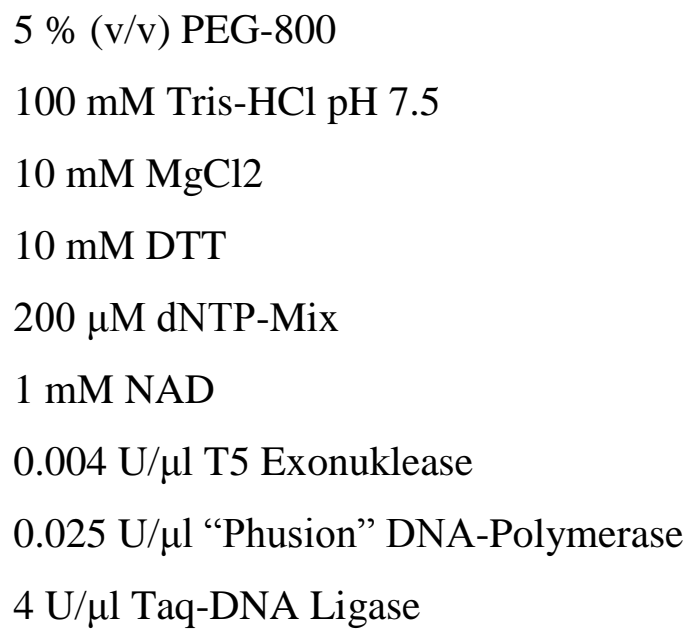

Für einen Reaktionsansatz von $20 \mu 1$, wurden 100 ng linearisierter Vektor und die zwei-fache Menge des DNA-Fragmentes mit homologen Überhängen in $10 \mu 1$ Nuklease-freiem Wasser gelöst und mit $10 \mu \mathrm{l} \mathrm{GA-Master} \mathrm{Mix} \mathrm{vermischt.} \mathrm{Der} \mathrm{Ansatz} \mathrm{wurde} \mathrm{für} 1$ bis $3 \mathrm{~h}$ bei $50{ }^{\circ} \mathrm{C}$ inkubiert.

\subsubsection{Transformation von E. coli Zellen mit Plasmid-DNA}

Die Herstellung chemisch-kompetenter Zellen erfolgte nach einem Standardprotokoll (Inoue et al., 1990). $250 \mathrm{ml}$ SOB-Medium wurden mit $10 \mathrm{ml}$ einer $E$. coli-Übernachtkultur beimpft und bei $25^{\circ} \mathrm{C}$ bis zum Erreichen der logarithmischen Wachstumsphase $\left(\mathrm{OD}_{600}=0,5\right.$ bis 0,7$)$ inkubiert. Nach einer 10 min Inkubation auf Eis wurden die Zellen sedimentiert (10 min, $4.400 \times \mathrm{g}, 4^{\circ} \mathrm{C}$ ), in $80 \mathrm{ml}$ eiskaltem TB-Puffer gelöst und weitere $10 \mathrm{~min}$ auf Eis inkubiert. Nach erneuter Zentrifugation ( $10 \mathrm{~min}, 4.400 \times \mathrm{g}, 4^{\circ} \mathrm{C}$ ) wurde das Sediment vorsichtig in 20 $\mathrm{ml}$ eiskaltem TB-Puffer aufgenommen. Durch Zugabe von DMSO zu einer Endkonzentration von $7 \%$ (v/v) konnten die Zellen im Anschluss an weitere 10 min auf Eis in aliquotierter Form in flüssigem Stickstoff schockgefroren und bis zur späteren Verwendung bei $-80^{\circ} \mathrm{C}$ gelagert werden. 


\section{$\underline{\text { TB-Puffer }(\mathrm{pH} 7,0) \text { : }}$}

$$
\begin{aligned}
& 10 \text { mM Pipes } \\
& 55 \mathrm{mM} \mathrm{MnCl} 2 \\
& 250 \mathrm{mM} \mathrm{KCl} \\
& 15 \mathrm{mM} \mathrm{CaCl} 2
\end{aligned}
$$

Die Transformation von E. coli mit Plasmid-DNA (modifiziert nach Hanahan, 1983) erfolgte mit 1 pg bis $1 \mu \mathrm{g}$ Plasmid-DNA bzw. dem gesamten Ligationsansatz. Die DNA wurde zu $100 \mu 1$ Transformations-kompetenten E. coli Zellen gegeben und 20 min auf Eis inkubiert. Während des sich anschließenden Hitzeschocks bei $42^{\circ} \mathrm{C}$ für 2 min, erfolgte die Aufnahme der Plasmid-DNA in die Zelle. Der Ansatz wurde im Anschluss umgehend mit $1 \mathrm{ml}$ LB-Medium versetzt und für 45 min bis $1 \mathrm{~h}$ bei $37^{\circ} \mathrm{C}$ geschüttelt. Die Zellen wurden nach einer Zentrifugation (1 min, 6.100x g, RT) in $50 \mu \mathrm{l}$ LB-Medium konzentriert, auf LBFestmedium mit entsprechenden Antibiotika ausplattiert und bebrütet. Gleichbehandelte Ansätze, denen keine DNA zugesetzt wurde, dienten hierbei als Negativkontrolle.

\subsubsection{Isolierung von Plasmid-DNA aus $E$. coli Zellen}

Für analytische Untersuchungen wurde die Plasmid-DNA von einer $10 \mathrm{ml}$ Übernachtkultur isoliert. Die Zellen wurden mit Hilfe des "NucleoSpin Plasmid" Kit von Machery-Nagel aufgeschlossen und nach entsprechenden Angaben des Herstellers behandelt. Die aufgereinigte DNA wurde in $50 \mu 1$ Nuklease-freiem Wasser gelöst.

Für die Herstellung von großen Mengen an Plasmid-DNA wurden $100 \mathrm{ml}$ (,high copy“ Plasmide) bis $200 \mathrm{ml}$ (,low copy“ Plasmide) einer Übernachtkultur verwendet. Für die Isolierung der Plasmid-DNA wurde das Kit "NucleoBond PC 100" von Machery-Nagel mit dem Protokoll des Herstellers genutzt. Anschließend wurde die DNA mit dem NanoDrop Spektrophotometer gemessen und auf eine Endkonzentration von $1 \mu \mathrm{g} / \mu \mathrm{l}$ mit Nukleasefreiem Wasser eingestellt. Alle erzeugten Plasmide wurden bei $-20^{\circ} \mathrm{C}$ gelagert.

\subsubsection{DNA-Sequenzierung}

Mit Ausnahme von Promotorbereichen wurden alle veränderten Plasmidbereiche nach ihrer Klonierung auf Korrektheit sequenziert. Die Sequenzierungsarbeiten wurden von der Firma LGC Genomics (aus Berlin/Deutschland) durchgeführt. Dafür wurden 0,5 $\mu \mathrm{g}$ bis $1 \mu \mathrm{g}$ Plasmid-DNA und $5 \mu \mathrm{M}$ des Sequenzier-Primers verwendet. Die Reaktion wurde mit 
Nuklease-freiem Wasser auf $14 \mu \mathrm{l}$ aufgefüllt, verpackt und an die Firma LGC Genomics verschickt.

\subsubsection{Herstellung der Plasmide pHK1279, pHK1417, pHK1418, pHK1419, pHK1443, pHK1444 und pHK1445}

Der Vektor pHK1279 wurde durch die Amplifikation des MTR2 Genes mit den Oligonukleotiden HK1332 und HK1333 aus genomischer Hefe-DNA (2.8.3) hergestellt. Das resultierende PCR-Produkt und der Vektor wurden mit XhoI und NdeI enzymatisch verdaut. Anschließend konnte das PCR-Produkt und der linearisierte Vektor mit kompatiblen Überhängen aufgereinigt und ligiert werden. Als Grundlage für die Herstellung der Vektoren pHK1417 und pHK1418 wurde der Vektor pHK922 verwendet. Für pHK1417 wurde der Vektor pHK922 mit MfeI und XhoI enzymatisch verdaut, wobei der Vektor dadurch linearisiert und anschließend aufgereinigt wurde. Ein PCR-Produkt mit dem ORF und den Promotor des HSP12 Genes wurde aus genomischer Hefe-DNA (2.8.3) mittels der Oligonukleotide HK1350 und HK1358 amplifiziert und aufgereinigt. Das PCR-Produkt und der linearisierte Vektor wurden mit Hilfe von kompatiblen Überhängen ligiert. Für die Herstellung von pHK1418 wurde die gleiche Methode verwendet, nur das das ACT1 Gen mit den Schnittstellen EcoRI und XhoI und den Oligonukleotiden HK1326 und HK1327 nach PCR mit genomischer Hefe-DNA und Aufreinigung in den Vektor integriert wurde. Für die Herstellung des Vektors pHK1419 wurde der pGEMT-Vektor (pHK1256) mit NheI und XmaI verdaut und so wurde der beinhaltete CBP-Tag herausgeschnitten. Durch Amplifikation der HIS-Sequenz mit den Oligonukleotiden HK1523 und HK1524 und dem anschließenden Schneiden mit NheI und XmaI, konnte die Sequenz in pHK1256 kloniert werden. Anschließend wurde das gesamte Konstrukt mittels NotI und XhoI aus dem pGEMT-Vektor herausgeschnitten und in den pHK1287 kloniert. Auch pHK1287 wurde vorher mit NotI und XhoI verdaut und aufgereinigt. Der Vektor pHK1443 wurde mit Hilfe des „Gibson Assembly“ Reaktionsmixes hergestellt. Dazu wurde der Leserahmen des CYC1 Genes inklusive des Promoters mittels PCR amplifiziert. Die verwendeten Oligonukleotiden HK1959 und HK1961 beinhalteten die Schnittstellen Kpn2I und NheI mit dessen Enzymen der Vektor pHK1417 hydrolytisch gespalten wurde. Der linearisierte Vektor und das aufgereinigte PCR-Produkt wurden zum „Gibson Assembly“ Reaktionsansatz hinzugegeben und nach Anleitung (2.7.6) behandelt. Ebenso wurde das Konstrukt pHK1444 (mit der Promoterregion des HSP12 Genes und dem Leserahmen von CYCl) mit den Oligonukleotiden HK1957 und HK1961 hergestellt. Auch das Konstrukt pHK1445 (mit der 
Promoterregion und des Leserahmens des HSP 12 Genes) wurde wie bereits beschrieben mit Hilfe des „Gibson Assembly“ Reaktionsmixes und den Oligonukleotiden HK1957 und HK1958 kloniert.

\subsection{Experimentelle Arbeiten mit S. cerevisiae}

\subsubsection{Verwendung von verschiedenen Stressbedingungen}

Zur Untersuchung verschiedener Stressbedingungen wurde eine Zellkultur bis zur logarithmischen Wachstumsphase (1-3x $10^{7}$ Zellen/ml) kultiviert und anschließend in verschiedene Fraktionen geteilt. Wobei immer eine Kontrolle ohne Stress bei $25^{\circ} \mathrm{C}$ mitgeführt wurde. Diese Kontrolle wurde direkt geerntet bei $4^{\circ} \mathrm{C}$ und 3.800x g für 3 min und direkt schockgefroren oder direkt mit einer Endkonzentration von $4 \%$ (w/v) Formaldehyd fixiert. Die Behandlung der Zellen mit einem Hitzestress erfolgte bei $42^{\circ} \mathrm{C}$ zwischen $10 \mathrm{~min}$ bis $1 \mathrm{~h}$. Anschließend wurden die Zellen wieder geerntet und schockgefroren oder direkt fixiert. Bei Salzstress wurde zu der vorhandenen Zellkultur $1 \mathrm{M}$ Natriumchlorid $(\mathrm{NaCl})$ hinzugegeben, gelöst und bei $25^{\circ} \mathrm{C}$ für $1 \mathrm{~h}$ inkubiert. Anschließend wurden die Zellen wie bereits beschrieben behandelt. Glukosestress wurde als eine weitere Stressbedingung durchgeführt, hierbei wurde die Zellkultur bei 3.800x g für 5 min zentrifugiert, mit destilliertem Wasser gewaschen und anschließend mit entsprechendem Medium ohne Kohlenstoffquelle versetzt. Unter diesen Hungerbedingungen wurden die Zellen für 10 min bei $25^{\circ} \mathrm{C}$ schüttelnd inkubiert und im Anschluss, wie zuvor beschrieben, behandelt.

\subsubsection{Transformation von $S$. cerevisiae mit Plasmid-DNA}

Die Transformation von Hefe wurde im Wesentlichen nach dem Standardprotokoll von Gietz et al., 1992 ausgeführt. Der Hefestamm wurde im entsprechenden Medium bei $25^{\circ} \mathrm{C}$ bis zum Erreichen der logarithmischen Wachstumsphase (1-3x $10^{7}$ Zellen/ml) kultiviert. Die Zellen wurden sedimentiert bei 4.000x $\mathrm{g}$ für $5 \mathrm{~min}$ und mit $1 \mathrm{ml} \mathrm{TE} /$ Lithiumacetat gewaschen. Nach dem erneuten Aufnehmen des Zellpelletes in TE/Lithiumacetat wurde die Zelldichte auf $1 \times 10^{9}$ Zellen/ml eingestellt. $50 \mu$ dieser Suspension wurden mit $1 \mu \mathrm{g}$ Plasmid und $50 \mu \mathrm{g}$ hitzedenaturierter Heringssperma-Träger-DNA vermischt. Nach Zugabe von $300 \mu \mathrm{PEG} / \mathrm{TE} /$ Lithiumacetat wurde die Probe für $30 \mathrm{~min}$ bei $25^{\circ} \mathrm{C}$ über Kopf rotiert. Nach dem anschließenden Hitzeschock für 15 min bei $42^{\circ} \mathrm{C}$ wurden die Zellen sedimentiert (1 min, 16100x g) und in Nuklease-freiem Wasser resuspendiert und auf entsprechendem Selektivagar ausplattiert und bei $25^{\circ} \mathrm{C}$ für zwei Tage inkubiert. 


\section{$\underline{\text { TE/Lithiumacetat }(\mathrm{pH} 7,5) \text { : }}$}

$100 \mathrm{mM}$ Lithiumacetat

$10 \mathrm{mM}$ Tris/ $\mathrm{HCl}$

$1 \mathrm{mM}$ EDTA

$\underline{\text { PEG/TE/Lithiumacetat ( } \mathrm{pH} 7,5):}$

$$
\begin{aligned}
& 40 \%(\mathrm{v} / \mathrm{v}) \text { PEG } 4000 \\
& 100 \mathrm{mM} \text { Lithiumacetat } \\
& 10 \mathrm{mM} \text { Tris/HCl } \\
& 1 \mathrm{mM} \mathrm{EDTA}
\end{aligned}
$$

\subsubsection{Isolierung von chromosomaler DNA}

Die Genomische DNA (gDNA) von Hefezellen wurde nach dem Standardprotokoll von Rose et al., 1990 extrahiert. Dafür wurden $10 \mathrm{ml}$ einer Übernachtkultur durch Zentrifugation bei 3.800x g für 5 min sedimentiert und der Überstand verworfen. Nach einmaligem Waschen mit $500 \mu 1$ Nuklease-freien Wasser wurden die Zellen in $50 \mu 1$ Nuklease-freiem Wasser resuspendiert. Der mechanische Aufschluss der Hefezellen erfolgte durch $200 \mu 1$ Detergens-Lyse-Puffer, $200 \mu$ l Phenol-Chloroform-Amylalkohol (25:24:1) (P/C/I), $300 \mu 1$ Glasperlen und der wiederholten Verwendung der FasPrep-24 Maschine (von MP Biomedicals/Frankreich) bei $5 \mathrm{~m} / \mathrm{s}$ für $20 \mathrm{sec}$. Anschließend wurden dem Ansatz $200 \mu \mathrm{l}$ TE-Puffer hinzugegeben und die Phasen durch Zentrifugation bei 21.100x g, für 5 min und Raumtemperatur separiert. Die wässrige, von Proteinresten befreite obere Phase wurde in ein neues $1,5 \mathrm{ml}$ Reaktionsgefäß überführt, das gleiche Volumen an P/C/I wurde erneut zugesetzt, intensiv gevortext und schließlich durch erneutes Zentrifugieren zur Trennung der Phasen gebracht. Dieser Schritt wurde solange wiederholt, bis die Zwischenphase klar war und keine Zell- oder Proteinreste mehr beinhaltete. Die saubere obere Phase wurden abgenommen und mit $6 \mu 1$ 7,5 M Ammoniumacetat und $1 \mathrm{ml}$ Ethanol (abs.) versetzt. Das entstandene Präzipitat wurde bei $4^{\circ} \mathrm{C}$ und 21.100x g für 10 min sedimentiert, und mit $1 \mathrm{ml}$ $70 \%$ (v/v) Ethanol einmal gewaschen. Nachdem die chromosomale DNA bei Raumtemperatur getrocknet wurde, konnte sie in 50-100 $\mu 1$ Nuklease-freiem Wasser gelöst und bis zum späteren Gebrauch bei $-20^{\circ} \mathrm{C}$ gelagert werden. 
Detergens-Lyse-Puffer ( $\mathrm{pH} 8,0)$ :

$$
\begin{aligned}
& 10 \mathrm{mM} \text { Tris/HCl } \\
& 1 \mathrm{mM} \text { EDTA } \\
& 2 \%(\mathrm{v} / \mathrm{v}) \text { Triton X-100 } \\
& 1 \%(\mathrm{w} / \mathrm{v}) \mathrm{SDS} \\
& 100 \mathrm{mM} \mathrm{NaCl}
\end{aligned}
$$

TE-Puffer (pH 8,0):

$10 \mathrm{mM}$ Tris/HCl

1 mM EDTA

\subsubsection{Isolierung von Gesamt-RNA aus Hefe}

\subsubsection{Aufreinigung der Gesamt-RNA mittels "NucleoSpin RNA"-Kit}

Die Hefezellen wurden in $50 \mathrm{ml}$ des entsprechenden Mediums bis zur logarithmischen Wachstumsphase (1-3x 107 Zellen/ml) kultiviert und anschließend entweder gestresst (2.8.1) oder direkt verwendet. Durch Zentrifugation wurden die Zellen bei $4^{\circ} \mathrm{C}$ und $16.100 \mathrm{x}$ g für 2 min sedimentiert und die Gesamt-RNA wurde mit Hilfe des "NucleoSpin RNA" Kits von Machery-Nagel aus den Zellen nach Herstellerangaben aufgereinigt. Die Durchführung des Protokolls beinhaltete auch eine DNaseI Behandlung der Proben. Schließlich wurde die RNA in $60 \mu \mathrm{l}$ DEPC-behandelten Nuklease-freiem Wasser gelöst und die Konzentration spektralphotometrisch ermittelt. Aufbewahrt wurde die RNA bis zur späteren Verwendung bei $-80^{\circ} \mathrm{C}$.

\subsubsection{Aufreinigung der Gesamt-RNA mittels Aqua-Phenol}

Zur Aufreinigung von größeren Mengen RNA, wurde die RNA mit Aqua-Phenol aus den Zellen isoliert (Schmitt et al., 1990). Dazu wurden die Zellen in $50 \mathrm{ml}$ einer Flüssigkultur mit dem entsprechenden Medium bis zur logarithmischen Wachstumsphase (1-3x $10^{7}$ Zellen/ml) kultiviert und anschließend entweder gestresst (2.8.1) oder direkt verwendet. Für die Herstellung des Zellpellets wurde die Probe bei 16.100x g für 2 min zentrifugiert und anschließend in $400 \mu 1$ 1x AE-Puffer mit zusätzlichen $40 \mu 110 \%$ SDS gelöst. Durch die Zugabe von gleichen Volumen Aqua-Phenol $(440 \mu 1)$ und durch das kurze Vortexen konnte die RNA mit Hilfe des geringen $\mathrm{pH}-$ Wertes $(\mathrm{pH} \mathrm{5,0)}$ extrahiert werden. Das Gemisch wurde für 5 min bei $65^{\circ} \mathrm{C}$ inkubiert und zwischendurch mehrmals invertiert. 
Im Anschluss wurde die Probe entweder in Trockeneis oder in einem $-80^{\circ} \mathrm{C}$ kaltem Ethanolbad für mindestens $30 \mathrm{~min}$ inkubiert und daraufhin für $5 \mathrm{~min}$ bei maximaler Geschwindigkeit zentrifugiert. Die entstandene obere wässrige Phase wurde in ein neues 1,5 ml Reaktionsgefäß überführt und erneut mit dem gleichen Volumen Aqua-Phenol versetzt. Nach kräftigem Vortexen wurde die Probe bei maximaler Geschwindigkeit für 5 min zentrifugiert. Erneut wurde die obere wässrige Phase entnommen und in ein sauberes 1,5 ml Reaktionsgefäß überführt. $\mathrm{Zu}$ der RNA wurde Aqua-P/C/I im gleichen Volumen hinzugegeben, 5 min gevortext und bei 16.100x g für 5 min zentrifugiert. Dieser Schritt wurde so oft wiederholt, bis die Zwischenphase klar war, ohne Zell- oder Proteinreste. Um Phenolreste aus der oberen wässrigen Phase zu entfernen wurde diese einmal mit dem gleichen Volumen an Chloroform/Isoamylalkohol (C/I) zugegeben und wieder ausdauernd gevortext und bei 16.100x g für 5 min zentrifugiert. Final wurde die obere wässrige RNAbeinhaltende Phase entnommen und 1/10 Volumen (v/v) des 3 M Natriumacetats ( $\mathrm{pH}$ 5,2) und das dreifache Volumen von Ethanol (abs.) hinzugefügt und bei $-80^{\circ} \mathrm{C}$ über Nacht präzipitiert. Damit die RNA pelletiert werden konnte, wurde diese bei $4^{\circ} \mathrm{C}$ und $16.100 \mathrm{x} \mathrm{g}$ für 30 min zentrifugiert. Anschließend wurde die RNA mit $70 \%$ DEPC haltigen Ethanol gewaschen und luftgetrocknet bis keine Flüssigkeit mehr erkennbar war. Die RNA wurde in $50 \mu 1$ Nuklease-freiem DEPC Wasser gelöst, Die Konzentration spektralphotometrisch gemessen und bei $-80^{\circ} \mathrm{C}$ zur späteren Verwendung gelagert.

\title{
10x AE-Puffer (pH 5,0):
}

\author{
$500 \mathrm{mM}$ Natriumacetat \\ 100 mM EDTA
}

\subsubsection{Quantitative RT-PCR (qRT-PCR)}

Die RT-PCR diente in dieser Arbeit für den Nachweis von Stress-induzierter RNA, die durch verschiedene Stressbedingungen (2.8.1) induziert wurden. Des Weiteren wurde die Methode für Untersuchungen von gebundener RNA an immunpräzipitierten Proteinen verwendet, da man mit dieser Methode auch kleinere Unterschiede in der RNA-Bindung feststellen kann (Hackmann et al., 2014). Für den Nachweis von Stress-induzierten RNAs wurde $1 \mu \mathrm{g}$ aufgereinigte RNA (2.8.4.1) mit „Random-Hexamer-Primern“ und der „Maxima-ReverseTranskriptase“ (beides von Thermo Scientific) mittels Herstellerangaben in cDNA 
umgeschrieben. Zur Kontrolle der Expression von Gesamt-RNA nach induziertem Stress, wurde im Anschluss eine analytische PCR durchgeführt. Dazu wurde die cDNA 1:50 verdünnt und mit 25 Zyklen wie bereits beschrieben (2.7.1), behandelt.

Für den Nachweis von gebundener RNA an immunpräzipitierten Proteinen wurde die quantitative (q)RT-PCR durchgeführt. Als Kontrolle für die Amplifikation unspezifisch bindender RNAs an die Matrix während der Co-Immunpräzipitation wurde jeweils eine Negativkontrolle mitgeführt. In dieser Kontrolle wurde der Wildtypstamm ohne immunpräzipitiertem Protein mit der Matrix inkubiert und die RNA wie in den zu untersuchenden Proben extrahiert. Dabei wurde der gesamte Überstand des Eluats für die cDNA-Synthese eingesetzt. Die cDNA jeder Probe wurde anschließend 1:5 verdünnt und jeweils $5 \mu \mathrm{l}$ der Verdünnung in Triplikaten von $20 \mu$ l Reaktionsansätzen eingesetzt. Der „GoTaq-qPCR-Master-Mix“ (von Promega) enthielt bereits SYBR Green, DNAPolymerase und Puffer. Die gewünschten Oligonukleotide die für die Analyse eingesetzt wurden sind in Tabelle 10 aufgeführt und wurden in einer Konzentration von je 0,1 $\mu \mathrm{M}$ eingesetzt. Die qRT-PCR wurde in einem Rotor Gene Q Gerät (Qiagen/Deutschland) betrieben.

qRT-PCR Programm:

45 Zyklen $\mid \begin{array}{lll}95^{\circ} \mathrm{C} & 5 \mathrm{~min} & \text { Initiale Denaturierung } \\ 95^{\circ} \mathrm{C} & 5 \mathrm{~s} & \text { Denaturierung } \\ 61^{\circ} \mathrm{C} & 10 \mathrm{~s} & \text { Hybridisierung } \\ 60^{\circ} \mathrm{C} & 15 \mathrm{~s} & \text { Elongation }\end{array}$

Für die Auswertung wurde der ,cycle threshold“ (ct)-Wert der Negativkontrolle von dem ctWert der eigentlichen Probe abgezogen. Dieser Wert ergab den $\Delta$ ct-Wert der Probe.

\subsubsection{Dot-Blot Analyse zur Detektion von poly $(\mathbf{A})^{+}$RNA}

Ein Northern „Dot-Blot“ Experiment wurde in dieser Arbeit für die quantitative Analyse von poly(A) ${ }^{+}$RNA Level angewendet (Hackmann et al., 2014; Lei et al., 2001). Proben von co-immunpräzipitierter RNA wurde in einem Volumen von $10 \mu$ gelöst und dann in regelmäßigen Abständen auf eine Hybond $\mathrm{N}^{+}$-Nylonmembran (GE Healthcare) getropft. Mit Hilfe eines „UV-Stratalinker 2400“ erfolgte eine UV-Bestrahlung der Membran bei einer 
Wellenlänge von $254 \mathrm{~nm}$ und $120000 \mu \mathrm{J} / \mathrm{cm}^{2}$, die eine kovalente Verknüpfung von RNAMolekülen und Nylonmembran bewirkte.

Als weitere Fixierung wurde die Membran für $2 \mathrm{~h}$ bei $80^{\circ} \mathrm{C}$ gebacken. Die Membran wurde anschließend in Prähybridisierungslösung für $1 \mathrm{~h}$ bei $42^{\circ} \mathrm{C}$ vorinkubiert. Darauffolgend wurden $10 \mu 1$ der DIG markierten Oligo-dT zu dem Hybridisierungsansatz hinzugegeben und über Nacht bei $42^{\circ} \mathrm{C}$ rotierend im Hybridisierungsofen inkubiert. Folgende Waschschritte wurde angeschlossen jeweils für $15 \mathrm{~min}$ : 2x SSC/0,1 \% SDS bei RT, 1x SSC/0,1 \% SDS bei Raumtemperatur und zweimal 0,5x SSC/0,1\% SDS bei $42^{\circ} \mathrm{C}$. Anschließend wurde die Membran 5 min in Waschpuffer geschwenkt und für 30 min mit 1x Blockierungspuffer blockiert. Darauffolgend wurde die Membran mit dem Enzym (AntiDigoxigenin-Alkaline Phosphatase, 1:10.000 in Blockierungspuffer von Roche verdünnt) für $30 \mathrm{~min}$ in 1x Blockierungspuffer schwenkend bei Raumtemperatur inkubiert. Nach zweimaligem Waschen der Membran für 15 min mit Waschpuffer wurde sie für 2-5 min mit Detektionspuffer äquilibriert. Im Anschluss erfolgte die Substratzugabe von CSPD (1:100 verdünnt in Detektionspuffer von Roche) für 5 min bei RT. Die Membran wurde in Folie luftdicht eingeschweißt und für $10 \mathrm{~min}$ bei $37^{\circ} \mathrm{C}$ inkubiert. Für die Detektion des poly(A) ${ }^{+}-$ Signals wurde entweder ein Röntgenfilm (Fuji) aufgelegt und anschließend entwickelt oder die Fusion SL (von Peqlab) detektierte das Signal über eine Kamera und die Signale konnten digital verwendet werden.

Prähybridisierungslösung:

$$
\begin{aligned}
& 0,5 \mathrm{M} \mathrm{Na}_{2} \mathrm{PO}_{4}(\mathrm{pH} 7,5) \\
& 7 \% \mathrm{SDS} \\
& 1 \mathrm{mM} \text { EDTA }
\end{aligned}
$$

20x SSC $(\mathrm{pH} 7,0):$

\author{
$3 \mathrm{M} \mathrm{NaCl}$ \\ 0,3 M Na-Citrat
}

$\underline{\text { 5x Maleinsäure-Puffer ( } \mathrm{pH} 7.5) \text { : }}$

0.5 M Maleinsäure

$0.75 \mathrm{M} \mathrm{NaCl}$ 
10x Blockierungslösung:

$$
\begin{aligned}
& 10 \%(\mathrm{w} / \mathrm{v}) \text { "blocking reagent” (von Roche) } \\
& 1 \mathrm{x} \text { Maleinsäure-Puffer }
\end{aligned}
$$

$\underline{\text { 1x Blockierungspuffer: }}$

10x Blockierungslösung verdünnt in 1 x Maleinsäure-Puffer

(Frisch angesetzt vor Gebrauch)

$\underline{\text { Waschpuffer: }}$

1x Maleinsäure-Puffer

$0.3 \%(\mathrm{v} / \mathrm{v})$ Tween-20

Detektionspuffer:

$$
\begin{aligned}
& 0.1 \mathrm{M} \text { Tris } \mathrm{pH} 9.5 \\
& 0.1 \mathrm{M} \mathrm{NaCl}
\end{aligned}
$$

\subsubsection{Synthese von Digoxigenin (DIG)-markierten RNA-Sonden}

Mit dieser Methode können spezifische RNAs mittels Digoxigenin (DIG) markiert und für Fluoreszenz in situ Hybridisierungsexperimenten (FISH) (2.9.2) verwendet werden. Die Bereitstellung der DIG-markierten RNAs erfolgte nach Herstellerangaben des „DIGlabeling Mix“ (von Roche Diagnostics). Die spezifischen RNA-Sonden wurden mit Hilfe von PCR Produkten hergestellt, die einen T7-RNA-Polymerase Promoter am „antisense“ Strang beinhalteten. Folgende Oligonukleotide wurden verwendet: HK1359 und HK1360 für SSA4 (1), eine Sonde im 5'-Bereichs des Leserahmens (ORFs), HK1361 und HK1362 für SSA4 (2) eine weitere Sonde im 3'-Bereichs des ORFs und HK1363 und HK1364 für einen Bereich innerhalb des HSP12-ORFs. Die PCR wurde mit gDNA (2.8.3) durchgeführt und das Produkt wurde aus einem präparativen Agarosegel ausgeschnitten und mit dem "peqGOLD Gel Extraktion Kit” (von Peqlab) aufgereinigt. Das PCR-Produkt wurde als Matrize für den in vitro Transkriptionsassay mit der T7-RNA Polymerase und den "DIG RNA labeling Mix” (von Roche) verwendet um eine ,antisense“-RNA-Sonde zu generieren. In dieser Reaktion wurde das DIG-11-UTP durchschnittlich alle 20- bis 25-mal in die neu synthetisierte RNA eingebaut. Der folgende Reaktionsansatz $(20 \mu \mathrm{l})$ wurde für $2 \mathrm{~h}$ bei $37^{\circ} \mathrm{C}$ inkubiert. 
$\underline{\text { In vitro Transkiptionsansatz: }}$

250 ng Matrize (aufgereinigtes PCR Produkt)

1x"DIG RNA labeling mix" (von Roche)

20 U RiboLock RNase Inhibitor (von Thermo Scientific)

$1 \mathrm{x}$ Transkriptionspuffer (von Thermo Scientific)

40 U T7-RNA-Polymerase (von Thermo Scientific)

Anschließend wurde die RNA durch die LiCl-Fällung präzipitiert. Der Reaktionsansatz wurde auf $50 \mu \mathrm{l}$ mit Nuklease-freiem Wasser aufgefüllt und 1/10 Volumen von $10 \mathrm{M} \mathrm{LiCl}$, $100 \mu \mathrm{g}$ tRNA und drei Volumen Ethanol (abs.) wurden hinzugegeben und bei $-80^{\circ} \mathrm{C}$ über Nacht inkubiert. Damit die RNA pelletiert werden konnte, wurde diese bei $4^{\circ} \mathrm{C}$ und 21.100x g für 60 min zentrifugiert. Anschließend wurde die RNA mit $70 \%$ DEPC-haltigen Ethanol gewaschen und auf Eis getrocknet bis keine Flüssigkeit mehr erkennbar war. Die RNA wurde in $25 \mu \mathrm{l} 1 \mathrm{M}$ TE-Puffer $\mathrm{pH}$ 7,5 mit $1 \mathrm{mg} / \mathrm{ml}$ Heparin gelöst und spektralphotometrisch gemessen. Anschließend wurden $25 \mu 1$ Formamid (deionisiert) hinzugegeben und mit $50 \mu \mathrm{l}$ Hyb-Mix gemischt. Gelagert wurden die RNA-Sonden bei $-20^{\circ} \mathrm{C}$ bis zur späteren Verwendung.

Hyb-Mix:

$50 \%(\mathrm{v} / \mathrm{v})$ de-ionisiertes Formamid

$5 \mathrm{x}$ SSC

1x Denhardt's

$0.1 \mathrm{mg} / \mathrm{ml}$ Heparin

mit Nuklease-freiem Wasser aufgefüllt

50x Denhardt's-Lösung:

$1 \%(\mathrm{w} / \mathrm{v})$ Ficoll

$1 \%(\mathrm{w} / \mathrm{v})$ Polyvinylpyrrolidon

$1 \%(\mathrm{w} / \mathrm{v}) \mathrm{BSA}$ 


\subsection{Zellbiologische Methoden mit S. cerevisiae}

\subsubsection{Fluoreszenzmikroskopie von lebenden Zellen}

Für alle fluoreszenzmikroskopischen Untersuchungen wurde das Leica DMI6000B Fluoreszenz-Mikroskop mit der Leica DFC360 FX Kamera verwendet und ausgewertet mit der LAS AF 2.7.3.9 Software. Für die Lokalisation von Proteinen bei Stress wurden diese direkt nach dem ausgesetzten Stress (2.8.1) auf ein Poly-L-Lysin beschichteten Objektträger gebracht und mit einem Deckgläschen abgedeckt und sofort mit dem Fluoreszenzmikroskop analysiert. Zur Kontrolle der Lokalisation der zu untersuchenden Proteine dienten Zellen, die bei $25^{\circ} \mathrm{C}$ inkubiert wurden.

\subsubsection{Fluoreszenz in situ Hybridisierungsexperimente}

Die Fluoreszenz in situ Hybridisierung (FISH) ist ein Verfahren, um RNA in einzelnen Zellen, mit Hilfe einer spezifischen Sonde, die komplementär über Basenpaarung an die RNA bindet, nachzuweisen (Amberg et al., 1992; Hackmann et al., 2014; Wu et al., 2014). Für die FISH von spezifischen RNAs und poly $(\mathrm{A})^{+}$RNA wurden Hefezellen verwendet, die sich in der logarithmischen Wachstumsphase befanden (1-3x $10^{7}$ Zellen/ml). Wie unter 2.8.1 beschrieben, wurden die Zellen unterschiedlich behandelt und durch Zugabe von $37 \%$ (v/v) Formaldehyd mit einer Endkonzentration von $4 \%$ (v/v) fixiert, was schwenkend für 60 min bei Raumtemperatur erfolgte. Die Hefezellen wurden durch Zentrifugation pelletiert (4.200x g, $3 \mathrm{~min}$ ). Anschließend wurde das Pellet dreimal mit $1 \mathrm{ml}$ eiskalter P-Lösung gewaschen und entsprechend der Zellmenge (ca. 1:1) in 100-500 $\mu$ l P-Lösung aufgenommen. Zur Permeabilisierung der Zellmembranen wurden $100 \mu$ der Zellsuspension mit 10 mM DTT für 10 min bei Raumtemperatur inkubiert und anschließend die Zellwand durch Zugabe von $50 \mu \mathrm{g}$ Zymolase enzymatisch verdaut. Die enzymatische Reaktion wurde im Phasenkontrastmikroskop verfolgt, bis ein gewisser Anteil der Hefezellen (50-75\%) Sphäroplasten bildeten und einen dunklen Kontrast erhielten. Die Zellen wurden durch vorsichtiges Zentrifugieren pelletiert (400x g, $5 \mathrm{~min}, 4^{\circ} \mathrm{C}$ ), einmal mit P-Lösung gewaschen und danach in einem angemessenen Volumen P-Lösung resuspendiert. Üblicherweise wurde eine hohe Zelldichte eingestellt, da die Anzahl der darauffolgenden Waschschritte die Zellzahl auf dem Objektträger stark minimierten. Währenddessen wurde der Objektträger mit Poly-L-Lysin behandelt (0,3 \% (w/v) Poly-L-Lysin, 5-15 min, RT), mit Nuklease-freiem Wasser gespült und sofort feucht oder luftgetrocknet verwendet. Anschließend wurden $25 \mu 1$ der Zellsuspension auf einen teflonbeschichteten 12-Loch-Objektträger gegeben und für 10- 
15 min bei Raumtemperatur inkubiert. Die Sphäroplasten wurden im Anschluss mit P-Lösung und 0,5\% (v/v) Triton X-100 für 10 min bei Raumtemperatur permeabilisiert und einmal kurz mit P-Lösung gewaschen. Nachdem die Sphäroplasten mit $0,1 \mathrm{M}$ Triethanolamin $(\mathrm{pH} \mathrm{8,0)}$ für 2 min bei Raumtemperatur äquilibriert wurden, folgte eine Inkubation mit 0,25\% (v/v) Essigsäureanhydrid in 0,1 M Triethanolamin ( $\mathrm{pH} \mathrm{8,0)} \mathrm{(10} \mathrm{min,}$ RT), wodurch die polaren Gruppen der Proteine blockiert wurden. Nach einmaligem Waschen mit P-Lösung wurden die Proben für $1 \mathrm{~h}$ bei $37^{\circ} \mathrm{C}$ mit dem Hyb-Mix (2.8.6) prähybridisiert und zusätzlich wurden noch $500 \mu \mathrm{g} / \mathrm{ml}$ tRNA und $500 \mu \mathrm{g} / \mathrm{ml}$ denaturierter Heringssperma-DNA hinzugegeben. Über Nacht erfolgte die Hybridisierung der Proben bei $37^{\circ} \mathrm{C}$ mit DIG-markierten oder Cy3-markierten Sonden (2.8.7). DIG-markierte Sonden wurden 0,1 $\mu$ 1/Probe eingesetzt, Sonden die mit Oligonukleotiden Cy3-endmarkiert waren, wurden $2 \mu \mathrm{l} /$ Probe verwendet und Oligo-dT50-Sonden, die mit Cy3 markiert waren, wurden mit $0,5 \mu 1 /$ Probe auf die Proben hinzugegeben. Die verwendeten Sonden wurden ebenfalls mit Hyb-Mix, tRNA und ssDNA vermischt. Nach Inkubation wurden die Zellen kurz mit 2x SSC und danach für 60 min bei Raumtemperatur mit 2x SSC inkubiert. Danach folgten Waschschritte mit folgenden Salzkonzentrationen - 1x SSC (60 min, RT), 0,5x SSC (30 $\min , 37^{\circ} \mathrm{C}$ ), 0,5x SSC (30 min, RT). Im Fall der DIG-markierten Sonde erfolgte nach einem Blockierungsschritt für $1 \mathrm{~h}$ bei Raumtemperatur mit ABB, eine Inkubation über Nacht bei $4^{\circ} \mathrm{C}$ mit einem Schaf-Anti-Digoxigenin-Fab-FITC-Antikörper (von Roche), der 1:200 in ABB verdünnt wurde. Folgende Waschschritte wurden anschließend bei Raumtemperatur durchgeführt: zweimal mit $\mathrm{ABB}$ für 15 min, einmal mit $\mathrm{ABB}$ für 30 min und zweimal mit 0,1 \% (v/v) Tween-20 in 1x PBS für 30 min. Im Anschluss wurde die DNA mit Hoechst 33342 (1:10.000 in 1x PBS verdünnt) für 5 min gefärbt und erneut dreimal für 5 min mit 1x PBS gewaschen. Danach wurde der Objektträger im Dunkeln getrocknet und abschließend in Mounting-Lösung eingebettet. Für eine Langzeitlagerung bei $-20^{\circ} \mathrm{C}$ wurde das Versiegeln mit klarem Nagellack durchgeführt.

\subsection{Phosphatpuffer ( $\mathrm{pH} 6.5)$ :}

$33 \mathrm{mM} \mathrm{K}_{2} \mathrm{HPO}_{4}$

$67 \mathrm{mM} \mathrm{KH}_{2} \mathrm{PO}_{4}$ 
P-Lösung:

\section{1,2 M Sorbitol \\ 0,1 M Kaliumphosphat-Puffer (pH 6,5)}

$\underline{1 x}$ PBS (pH 7.4):

$$
\begin{aligned}
& 137 \mathrm{mM} \mathrm{NaCl} \\
& 2.7 \mathrm{mM} \mathrm{KCl} \\
& 10 \mathrm{mM} \mathrm{Na} 2 \mathrm{HPO} 4 \\
& 1.8 \mathrm{mM} \mathrm{KH} 2 \mathrm{PO} 4
\end{aligned}
$$

Zymolase-Solution:

$10 \mathrm{mg} / \mathrm{ml}$ Zymolase

2 mM Vanadyl-Ribonukleosid-Komplex

$1 \mathrm{mg} / \mathrm{ml}$ Heparin

Antikörper Blockierungspuffer (ABB):

1x PBS

$5 \%(\mathrm{w} / \mathrm{v})$ hitze-inaktiviertes FBS

$0.3 \%(\mathrm{v} / \mathrm{v})$ Triton-X100

Mounting-Lösung (pH 8,0):

$$
\begin{aligned}
& 2 \%(\mathrm{w} / \mathrm{v}) \text { n-Propyl-Gallat } \\
& 80 \%(\mathrm{v} / \mathrm{v}) \text { Glycerin }(100 \%(\mathrm{v} / \mathrm{v})) \\
& \text { in PBS (pH 8,0) }
\end{aligned}
$$

\subsubsection{GFP-Mikroskopie}

Anzucht, Ernte und Fixierung der Zellen erfolgte für die GFP-Mikroskopie-Studien genauso wie in 2.9.2 beschrieben, jedoch wurden die Zellen nur für 5 min fixiert (Windgassen und Krebber, 2003). Um die fluoreszierende Struktur von GFP zu erhalten wurden die Zellen sofort nach Zugabe von Formaldehyd pelletiert und in P-Lösung gewaschen. In GFPMikroskopie-Studien sollte die Zellsuspension eine deutlich geringere Zelldichte aufweisen, da in dieser Methode weniger Waschschritte zum Einsatz kommen. 
Die Behandlung und Beladung des Objektträgers erfolgte wie in 2.9.1 erläutert. Nach der Behandlung mit Triton-X 100 wurden die Zellen mit P-Lösung und 1x PBS gewaschen und die DNA-Färbung mit Hoechst 33342 durchgeführt.

\subsubsection{Statistische Auswertung der Mikroskopiebilder}

Zur Quantifizierung der Mikroskopiebilder wurden die Intensitäten des Zellkernsignales im Vergleich zur gesamten Zelle von mindestens 10 Zellen gemessen. Die Auswertung erfolgte mit der Fiji-Software und die Signifikanzen der Anreicherung des Zellkernsignals wurde mit dem ungepaarten T-Test des Typs 2 anhand von Microsoft Excel 2010 berechnet.

\subsection{Proteinbiochemische Methoden}

\subsubsection{Die Herstellung von Zelllysaten}

Die Zellen wurden, wie unter 2.8.1 beschrieben, behandelt und ein entsprechendes Zellpellet wurde aus 1-3 $\times 10^{7}$ Zellen/ml gewonnen. Zur Herstellung der Zelllysate wurde je nach Menge des Zellpellets bis $500 \mu 1$ in ein 2 ml-Schraubdeckelgefäß oder über $500 \mu 1$ in ein $15 \mathrm{ml}$ Falkon überführt. Für den Aufschluss wurden alle nächstfolgenden Schritte auf Eis ausgeführt. Dem Zellpellet wurde das gleiche Volumen des für den jeweiligen Assayspezifischen Puffers und ein Volumen Glasperlen zugefügt. Um den verstärkten Proteinabbau während des Aufschlusses von Hefe $\mathrm{zu}$ verhindern, wurde eine Proteaseinhibitor-Mischung (von Roche) mit $5 \mu \mathrm{lu} 100 \mu \mathrm{l}$ Zellpellet hinzugegeben. Für den Zellaufschluss wurden die Ansätze mit der FastPrep Maschine mit 5 bis 6 m/s für $25 \mathrm{~s}$, zwei- bis dreimal gevortext. Die entstandene Zellsuspension wurde mit mehrmaligem Reaktionsgefäßwechsel zentrifugiert (dreimal $10 \mathrm{~min}, 16100 \mathrm{x} \mathrm{g}, 4^{\circ} \mathrm{C}$ ), bis das Zelllysat klar wurde und kein Pellet nach dem Zentrifugieren sichtbar war.

Die E. coli Zellen wurden mittels Ultraschall aufgeschlossen. Das Zellpellet (ca. $1 \mathrm{~g}$ Feuchtgewicht) wurde in einem $50 \mathrm{ml}$-Falkon in $4 \mathrm{ml}$ des gewünschten Puffers resuspendiert. Die Zellsuspension wurde in einem Eisbad unter der Vermeidung von Schaumbildung solange sonifiziert bis die Suspension ihre Trübung verlor. Der Proteinüberstand wurde auch mit mehrmaligem Gefäßwechsel bei $4^{\circ} \mathrm{C}$ und $16.100 \mathrm{x} g$ zentrifugiert und für darauffolgende Experimente vorbereitet. 


\title{
2.10.2 Co-Immunpräzipitation (Co-IP) zur Analyse von Protein-Protein und RNA-Protein Interaktionen (RIP)
}

Zelllysate von Hefezellen wurden wie unter 2.10.1 beschrieben, gewonnen (Baierlein et al., 2013; Gross et al., 2007). Der Reaktionsansatz richtete sich nach der Expression des gewünschten Proteins, das immunpräzipitiert werden sollte. Für Protein-ProteinInteraktionsstudien wurde, der PBSKMT-Puffer verwendet. Dabei wurde für Interaktionsstudien eine Triton-Konzentration von 0,5\% gewählt. Je nach Markierung des gewünschten Proteins wurde für GFP co-exprimierte Proteine die Matrix der GFP-Trap_A® (von ChromoTek) verwendet und für myc co-exprimierte Proteine wurde der Anti-Maus Antikkörper (von Santa Cruz) verwendet. $2 \mu \mathrm{g}$ des Antikörpers wurden mit $10 \mu \mathrm{l}$ Protein G Sepharose (50\%-ige Suspension) den Lysaten zugesetzt und für $4 \mathrm{~h}$ bei $4^{\circ} \mathrm{C}$ drehend inkubiert. Auch von der GFP-Trap_A® wurden $10 \mu 1$ einer 50\%-igen Suspension pro Reaktion verwendet. Nach der Rotation für mindestens $3 \mathrm{~h}$ bei $4^{\circ} \mathrm{C}$ wurden die Beads in den Reaktionsansätzen fünfmal mit 1-2 ml PBSKMT-Puffer über Kopf drehend gewaschen und jeweils bei 2000x g für 2 min pelletiert. Anschließend wurden die Matrix in SDS-Probenpuffer (2.10.7) aufgenommen und die Proteine 5 min bei $95^{\circ} \mathrm{C}$ eluiert. $\mathrm{Im}$ Anschluss wurden die Proben für die SDS-PAGE verwendet (2.10.7).

\section{PBSKMT-Puffer:}

\author{
$1 x$ PBS \\ $3 \mathrm{mM} \mathrm{KCl}$ \\ 2,5 $\mathrm{mM} \mathrm{MgCl} 2$ \\ $0,5 \%(\mathrm{v} / \mathrm{v})$ Triton $\mathrm{X}-100$
}

Speziell für RNA-Protein-Interaktionsstudien (RIP) wurde dem RNA-IP-Puffer zusätzlich zu den Proteaseinhibitoren noch Rnase-Inhibitor (RiboLock) beigefügt (Hackmann et al., 2014; Hurt et al., 2004). Die Lysate wurden vor der Co-Immunpräzipitation mit DnaseI mit einer Endkonzentration von $10 \mathrm{U} / \mathrm{ml}$ für 30 min bei $30^{\circ} \mathrm{C}$ behandelt. Nach Inkubation und Waschen mit RNA-IP-Puffer der Beads wurden sie in zwei Fraktionen geteilt. Ein Zehntel wurde für die Analyse mittels SDS-PAGE in SDS-Proben-Puffer aufgenommen (2.10.7), der andere Teil der Beads wurde mit Proteinase-K bei $37^{\circ} \mathrm{C}$ für 30 min behandelt und anschließend mit einer Phenol-Chloroform-Mischung gevortext. Der entstandene Überstand wurde noch einmal mit Chloroform ausgeschüttelt. Die wässrige, RNA-haltige Phase wurde 
mit 0,1 Volumen $1 \mathrm{M} \mathrm{LiCl}, 0,9$ Volumen Ethanol und $20 \mu \mathrm{g}$ Glykogen versetzt, über Nacht bei $-80^{\circ} \mathrm{C}$ präzipitiert und pelletiert bei $16100 \mathrm{x}$ g für $45 \mathrm{~min}$ und $4^{\circ} \mathrm{C}$. Letztlich wurde das Pellet mit 70\%-igem Ethanol gewaschen und bei $55^{\circ} \mathrm{C} 2-3$ min getrocknet, bevor die RNA in $10 \mu \mathrm{l}$ Rnase-freiem Wasser gelöst wurde. Die so co-immunpräzipitierte RNA wurde entweder in einer Dot-Blot-Analyse verwendet oder in qRT-PCR-Experimenten eingesetzt.

RNA-IP-Puffer:

\author{
$25 \mathrm{mM}$ Tris- $\mathrm{HCl}(\mathrm{pH} 7.5)$ \\ $100 \mathrm{mM} \mathrm{KCl}$ \\ $0,5 \%(\mathrm{v} / \mathrm{v})$ Triton X-100 \\ 5 mM DTT
}

\title{
2.10.3 Zwei-Schritt-Affinitätsreinigung zur Analyse von RNA-Protein- Interaktionen
}

Für Untersuchungen von RNA-Protein-Interaktionen können mRNAs in lebenden Zellen markiert werden und lassen sich so spezifisch präzipitieren (Slobodin und Gerst, 2010). Dazu wurde eine artifizielle Haarnadelstruktur (MSIIL) aus dem Bakteriophage MS2 an das 3'-Ende des ORFs der zu-untersuchenden mRNA kloniert. Diese Haarnadelstruktur wird von dem Phagenprotein MS2 „coating protein“ kovalent gebunden und über weitere Proteintags kann die spezifische mRNA präzipitiert werden. In der vorliegenden Arbeit wurde $3{ }^{6}$-seitig an den HSP12 ORF die Haarnadelstruktur (MSIIL) in den Vektor pHK1417 kloniert und Hefezellen die das HSP12 Gen deletiert hatten, mit dem Konstrukt transformiert (2.8.2). Das Phagenprotein, welches mit weiteren Fusionstags co-exprimiert wurde, wurde auf einen weiteren Vektor (pHK1419) in die Hefezellen eingebracht. Bei den Fusionsproteinen handelte es sich um ein His-Tag und ein ProteinA-Tag, dass durch eine TEV-Schnittstelle vom His-Tag abgegrenzt wurde. Die mRNA-MSIIL wurde von dem MS2CP gebunden und über die Proteintags affinitätsgereinigt, da das ProteinA an die IgG Sepharose gebunden hatte, konnte der gesamte Komplex präzipitiert werden. Nach dem Schneiden mit der TEV-Protease, wurde das ProteinA-Tag vom restlichen Konstrukt getrennt und im zweiten Aufreinigungsschritt erfolgte die Bindung an die Nickel-NTAAgarose, durch das His-Tag. 
Wildtypzellen, die als Kontrolle ohne MSIIL-Konstrukt verwendet wurden und hsp124 Zellen mit dem $P_{H S P 12}$-HSP12-MSIIL-Konstrukt wurden logarithmisch bis zu einer Zellzahl von $2-3 \times 10^{7}$ Zellen/ml kultiviert. Die Hefekulturen wurden pelletiert und anschließend aufgeteilt. Die Hälfte wurde in vorgewärmtem Mangelmedium bei $42^{\circ} \mathrm{C}$ für 20 min einem Hitzestress ausgesetzt. Der andere Teil der geernteten Zellen wurden in Flüssigstickstoff eingefroren und bei $-20^{\circ} \mathrm{C}$ gelagert. Vor der Zelllyse wurden entsprechende Mengen an Proteaseinhibitoren (5 $\mu 1$ pro $100 \mu$ l Zellpellet) (von Roche), Phosphataseinhibitoren (100x), und $1 \mu 1$ Rnase-Inhibitoren (RiboLock/ThermoFisher) hinzugegeben, um die Stabilität der Komplexe zu erhalten. Nachdem die Zellen aufgeschlossen wurden und eine Zelllysatprobe als Kontrolle entnommen wurde, wurde die IgG Sepharose, zu dem Zelllysat hinzugegeben und bei $4^{\circ} \mathrm{C}$ für $4 \mathrm{~h}$ inkubiert. Die IgG Sepharose wurde fünfmal mit Waschpuffer gewaschen und daraufhin über Nacht mit der TEV-Protease und $1 \mathrm{ml}$ Waschpuffer bei $4^{\circ} \mathrm{C}$ auf dem Rotator inkubiert. Der Überstand wurde entnommen und mit einer Nickel-AgaroseMatrix für $4 \mathrm{~h}$ bei $4^{\circ} \mathrm{C}$ inkubiert. Im Anschluss wurde die Nickel-Agarose-Matrix fünfmal mit Waschpuffer gewaschen und mit zweifachem SDS-Probenpuffer versehen. Es wurden nach jedem Aufreinigungsschritt Proben entnommen. Mit den entnommenen Proben wurden Expressionsanalysen auf RNA- und Proteinebene durchgeführt.

$\underline{1 x} \operatorname{PBS}(\mathrm{pH} 7,4)$ :

$$
\begin{aligned}
& 137 \mathrm{mM} \mathrm{NaCl} \\
& 2,7 \mathrm{mM} \mathrm{KCl} \\
& 10 \mathrm{mM} \mathrm{Na} 2 \mathrm{HPO} 4 \\
& 2 \mathrm{mM} \mathrm{KH} 2 \mathrm{PO} 4
\end{aligned}
$$

Waschpuffer:

$$
\begin{aligned}
& \text { 1x PBS } \\
& 3 \mathrm{mM} \mathrm{KCl} \\
& 2,5 \mathrm{mM} \mathrm{MgCl} 2 \\
& 0,5 \%(\mathrm{v} / \mathrm{v}) \text { Triton X-100 }
\end{aligned}
$$

\subsubsection{Affinitätsreinigung heterolog exprimierter Proteine}

Zur Untersuchung der direkten Bindung von RNA-Bindeproteinen mit RNA wurden in vitro RNA-Bindungsstudien durchgeführt mit rekombinanten Proteinen die in E. coli Rosetta 2 (DE3) (von Novagen) oder in E. coli BL21 Zellen exprimiert wurden. 
Die E. coli Rosetta 2 Zellen unterstützen das T7-Expressionssystem und besitzen ein Plasmid, welches eine zusätzliche Chloramphenicolresistenz beinhaltet und zusätzliche tRNAs für selten genutzte Codons in E. coli exprimiert. Dadurch können eukaryotische Proteine besser exprimiert werden, die spezielle Codons brauchen.

Die Expression der Glutathione-S-Transferase (GST)- und His6 co-exprimierten rekombinanten Hefeproteine und die anschließende Affinitätsaufreinigung wurde nach den Standardprotokollen von (Smith und Corcoran, 2001) und (Harper und Speicher, 2008) durchgeführt. Für erste in vitro Untersuchungen von Mex67-Mtr2 mit Hefe-RNA wurde GST-Mex67 und Mtr2-His 6 auf zwei Plasmiden in einer E. coli BL21 Zelle exprimiert. Vorangegangene Untersuchungen zeigten, dass Mex67 allein instabil ist und nach Aufschluss der Bakterien präzipitierte. Erst durch die Anwesenheit von Mtr2 bleibt der Komplex im Zelllysat weitestgehend stabil und löslich. Es wurden $200 \mathrm{ml}$ E. coli BL21 Zellen mit 2 mM IPTG induzierten GST-Mex67 und Mtr2-His6 nach zweitägiger Kultivierung bei $16^{\circ} \mathrm{C}$ geerntet. Anschließend wurde das Zellpellet in $4 \mathrm{ml}$ des Bindepuffers gelöst und wie unter 2.10.1 beschrieben sonifiziert und zentrifugiert. Das bakterielle Lysat wurde dann mit der $20 \mu$ l einer 50\%-igen Suspension von Glutathione-Sepharose 4B Beads (von GE Healthcare) und $50 \mu \mathrm{g}$ aufgereinigter Hefe-RNA bei $4^{\circ} \mathrm{C}$ für $1 \mathrm{~h}$ rotierend inkubiert. Im Anschluss wurden die Beads 7-mal mit dem Bindepuffer gewaschen und in zwei Fraktionen geteilt. Ein Zehntel der Beads diente als Expressionskontrolle der Proteine und wurde deshalb in 3x SDS-Proben-Puffer aufgenommen und mittels SDS-PAGE analysiert (2.10.7). Der andere Teil der Beads wurde zum Verdau bakterieller DNA für 30 min bei $37^{\circ} \mathrm{C}$ mit Dnase I (von Thermo Scientific) behandelt, anschließend mit Proteinase-K für weitere $30 \mathrm{~min}$ bei $37^{\circ} \mathrm{C}$ inkubiert und zum Schluss mit einer Phenol-Chloroform-Mischung gevortext. Der Überstand wurde noch einmal mit Chloroform ausgeschüttelt. Danach wurde die obere wässrige RNA-haltige Phase mit 0,1 Volumen $10 \mathrm{M} \mathrm{LiCl,} \mathrm{0,9} \mathrm{Volumen} \mathrm{Ethanol}$ und $20 \mu \mathrm{g}$ Glykogen versetzt, über Nacht bei $-80^{\circ} \mathrm{C}$ präzipitiert und bei $16100 \mathrm{x}$ g für $45 \mathrm{~min}$ und $4{ }^{\circ} \mathrm{C}$ pelletiert. Letztlich wurde das Pellet mit 70\%-igem Ethanol gewaschen und bei $55^{\circ} \mathrm{C} 2-3$ min getrocknet, bevor die RNA in $10 \mu 1$ Rnase-freiem Wasser gelöst wurde. Die RNA wurde schließlich in der qRT-PCR (2.8.5) eingesetzt. Als Negativkontrolle für unspezifische Bindung der RNA an die Beads wurde GST ohne Mex67 mit aufgereinigtem Mtr2 mitgeführt. Als Positivkontrolle für die RNA-Bindung an ein rekombinantes Protein diente die Expression und die Verwendung des mRNA-Bindeproteins GST-Npl3. Hierzu wurde die beschriebene Methode parallel durchgeführt. 
Bindepuffer:

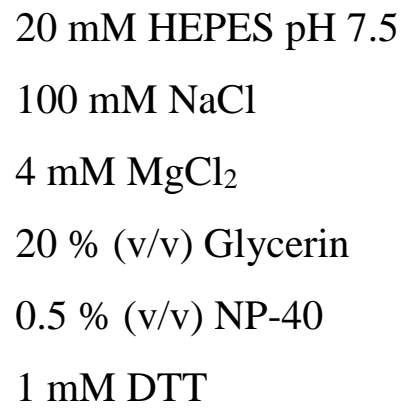

“Complete”, EDTA-freie Protease-Inhibitor-Cocktail (von Roche)

In weiteren Experimenten wurden $E$. coli Rosetta 2 Zellen verwendet für die Affinitätsreinigung der polycistronisch-exprimierten Proteine His-Mtr2 und Mex67. Bakterienzellen wurden in $200 \mathrm{ml}$ AI-Medium (Autoinduzierenden Medium) für $72 \mathrm{~h}$ bei $16^{\circ} \mathrm{C}$ kultiviert und gleichzeitig wurden die Proteine exprimiert. Anschließend wurden die Zellen bei $4.400 \mathrm{x} \mathrm{g}$ und $10 \mathrm{~min}$ bei $4^{\circ} \mathrm{C}$ geerntet und wie in 2.10 .1 lysiert. Mittels Bindepuffers und der Protino-Ni-IDA Säulenchromatographie (von Machery \& Nagel) entsprechend der Veröffentlichung von Yao et al. (2007) wurden die Proteine aufgereinigt und bei $-80^{\circ} \mathrm{C}$ in Elutionspuffer gelagert. Neben dem wildtypischen Mex67 wurden auch Mutanten von Mex67 im Komplex mit Mtr2 aufgereinigt und für RNA-Bindungsstudien verwendet. Dazu wurden $100 \mu \mathrm{g}$ Gesamt-Hefe-RNA in Elutionspuffer und den aufgereinigten Proben eine Stunde bei $4^{\circ} \mathrm{C}$ zusammen mit Ni-NTA Agarose rotierend inkubiert. Im Anschluss wurden die Beads wie bereits beschrieben 7-mal gewaschen und in zwei Fraktionen geteilt. Der weitere Verlauf des Experimentes schließt sich an die beschriebene Durchführung an.

Elutionspuffer:

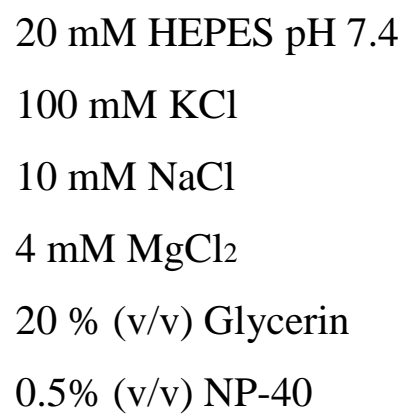

"Complete", EDTA-freie Protease-Inhibitor-Cocktail 


\title{
2.10.5 Analyse von Ribosomenprofilen mittels Saccharose-Dichtegradienten- Zentrifugation
}

Zur Auftrennung von ribosomalen Komplexen nach ihrer Größe wurden SaccharoseDichtegradienten Fraktionierungsexperimente durchgeführt, wie bereits veröffentlich wurde (Frey et al., 2001; Mašek et al., 2011). Dabei wurden Hefezellen in einem Volumen von $200 \mathrm{ml}$ bei $25^{\circ} \mathrm{C}$ in logarithmischer Phase angezogen. Die Behandlung erfolgte wie in 2.8.1 beschrieben, entweder als Hitzestress bei $42^{\circ} \mathrm{C}$ für 20 min oder ungestresst. Vor der Ernte wurde Cycloheximid in einer finalen Konzentration von $100 \mu \mathrm{g} / \mathrm{ml}$ der Kultur zugegeben und bei der entsprechender Temperatur für 5 min und anschließend für 15 min auf Eis inkubiert. Die Prozedur zur Herstellung von Zelllysaten in Gradientenlyse-Puffer erfolgte im Wesentlichen wie in 2.10 .1 beschrieben.

\section{Gradientenlyse-Puffer}

\author{
20 mM HEPES-KOH (pH 7.5) \\ $100 \mathrm{mM} \mathrm{KCl}$ \\ $2.5 \mathrm{mM} \mathrm{MgCl}_{2}$ \\ $1 \mathrm{mM}$ DTT \\ $100 \mu \mathrm{g} / \mathrm{ml}$ Cycloheximid
}

Die Herstellung des linearen $12 \mathrm{ml}$ Saccharosegradienten erfolgte mittels des GradientMaster-Geräts in Polyallomer Röhrchen. Je nach Auftrennungsgrad der Ribosomen kann ein 4-55\%-iger Gradient eingesetzt werden. Standardmäßig in dieser Arbeit wurden für die niedrigkonzentrierte $10 \%$ und für die hochprozentige Lösung 50 \% Saccharose verwendet. Diese wurden dann in der Apparatur zusammen zu einem linearen Gradienten vermischt und auf Eis in den Zentrifugen Einsätzen vorgekühlt.

$\underline{\text { Saccharosegradienten-Puffer }}$

$20 \mathrm{mM}$ HEPES-KOH (pH 7,5)

$100 \mathrm{mM} \mathrm{KCl}$

2,5 $\mathrm{mM} \mathrm{MgCl} 2$

Entweder $10 \%(w / v)$ oder $50 \%$ (w/v) Saccharose 
Durch eine Absorptionsmessung mit dem NanoDrop Spektrophotometer bei $260 \mathrm{~nm}$ konnte sichergestellt werden, dass alle Gradienten Röhrchen mit gleicher Menge Zelllysat beladen werden. Danach wurden je Stamm 8 Units des Lysats auf den Saccharosegradienten gegeben und bei 201.149 x g für $3 \mathrm{~h}$ in einem TH-641 Rotor in der Sorvall WX80 Ultrazentrifuge (von Thermo Scientific) zentrifugiert. Nach der Zentrifugation wurden die GradientenProben mit Hilfe des Dichtegradienten-Fraktionssystems (von Teledyne Isco) und dem Einpumpen von 60\%-iger Saccharose Lösung bei einer Geschwindigkeit von 20\% in ca. $600 \mu \mathrm{l}$ fraktioniert und aufgefangen. Dabei wurde kontinuierlich ein Spektrogramm bei $254 \mathrm{~nm}$ aufgenommen. Die Fraktionen des Gradienten konnten für weitere Experimente genutzt werden, z. B. Analyse der enthaltenen Proteine über eine TCA-Fällung oder bei $-20^{\circ} \mathrm{C}$ gelagert werden. Zur Untersuchung, ob Proteine spezifisch an die Translationskomplexe gebunden sind, wurden Kontrollexperimente mit folgenden Modifikationen vorgenommen: Die Zellextrakte wurden mit Puromycin und GTP zu einer Endkonzentration von je $1 \mathrm{mM}$ versetzt und vor dem Beladen des Gradienten für $15 \mathrm{~min}$ bei $25^{\circ} \mathrm{C}$ oder $42^{\circ} \mathrm{C}$ inkubiert. Der Einsatz von Puromycin führte zu einer selektiven Zerstörung der Polysomen, da das Antibiotikum als Aminoacyl-tRNA-Analogon agiert. Die wachsende Peptidkette wird in Gegenwart von GTP hierauf übertragen, woraufhin es zu einem vorzeitigen Kettenabbruch und einer Dissoziation der Ribosomen von den mRNAMolekülen kommt (Blobel und Sabatini, 1971). Ansonsten wurde der Ansatz identisch wie bereits beschrieben durchgeführt.

\subsubsection{Fällung von Proteinen mittels TCA}

Um Proteine aus wässrigen Lösungen zu präzipitieren wurde das gleiche Volumen 20\%-ige Trichloressigsäure (TCA) (w/v) zugegeben, gut gemischt und 10 min auf Eis inkubiert. Das Präzipitat wurde bei 21.100x g für 10 min pelletiert. Um Reste der Säure zu entfernen, wurde das Pellet zweimal mit 80\%-igem Aceton (v/v) gewaschen und anschließend bei Raumtemperatur getrocknet. Um die Proteine großer Pellets wieder in Lösung zu bringen, wurde mindestens $30 \mu$ l SDS-Proben-Puffer hinzugegeben und die Proben in einem 1,5 ml Reaktionsgefäß-Schüttler 10 min gevortext.

\subsubsection{SDS-Polyacrylamid-Gelelektrophorese (SDS-PAGE)}

Zur Auftrennung von Proteinen wurde eine diskontinuierliche SDS-PolyacrylamidGelelektrophorese (SDS-PAGE) angewendet, die auf den Standardprotokollen aufbaut 
(Garfin, 1990; Laemmli, 1970). Das SDS-Gel besteht aus einem 5\%-igen Sammelgel und standardmäßig 10\%-igen Trenngel.

$\underline{\text { Sammelgel }(5 \%)}$

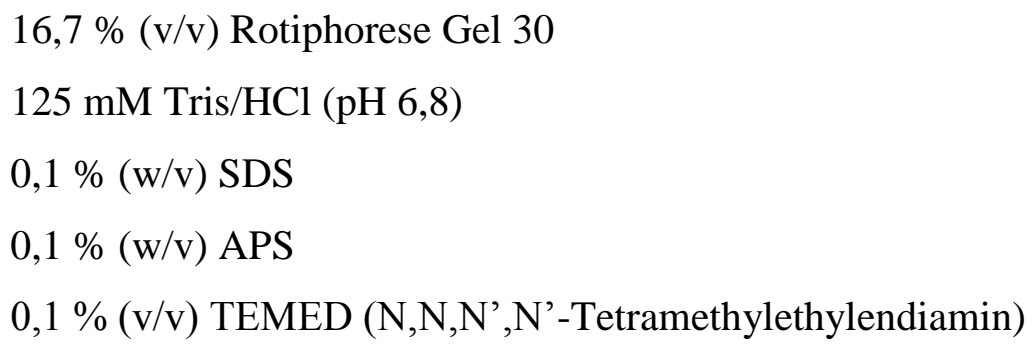

Trenngel (10\%)

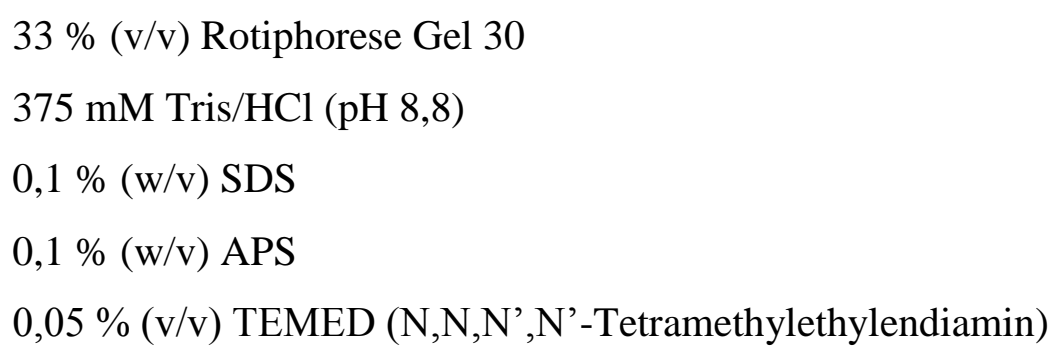

Für die Probenaufbereitung wurden ca. $100 \mu$ g Proteinlysate oder Reaktionsansätze aus IPExperimenten mit SDS-Proben-Puffer versetzt und 5 min bei $95^{\circ} \mathrm{C}$ inkubiert.

$\underline{\text { SDS-Probenpuffer }(3 x)}$

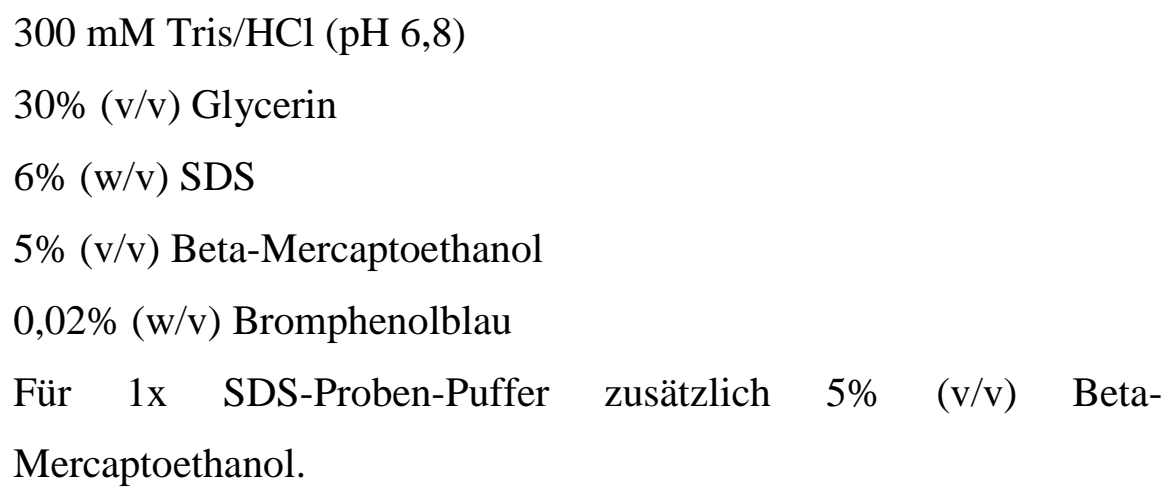

Die zu analysierenden Proben wurden zusammen mit Protein-Größenstandards (,,unstained “ oder „prestained“ Proteinmarker - „PageRuler“ von Thermo Scientific) in die Geltaschen des SDS-Gels geladen. Die Proben wurden anschließend in einer mit SDS-ElektrophoresePuffer gefüllten Apparatur bei $25 \mathrm{~mA}$ im Sammelgel und $35 \mathrm{~mA}$ im Trenngel oder bei $7 \mathrm{~mA}$ über Nacht aufgetrennt. 
$\underline{\text { SDS-Elektrophorese-Puffer }}$

$25 \mathrm{mM}$ Tris

192 mM Glycin

$0,1 \%(\mathrm{w} / \mathrm{v}) \mathrm{SDS}$

\title{
2.10.7.1 „Coomassie-Blue $e^{6}$ Färbung von SDS-Polyacrylamidgelen
}

Für Expressionskontrollen in Heterologen Systemen und für die Kontrolle der gleichen Proteinbeladung wurden die SDS-Polyacrylamidgele mit „Coomassie-Blue“ gefärbt. Dafür wurden die Gele für 10 min in Färbelösung geschwenkt. Nach der Färbung wurde das Gel mit Entfärber bedeckt und solange geschwenkt bis die Proteinbanden sichtbar waren.

Färbelösung

\author{
$50 \%(\mathrm{v} / \mathrm{v})$ Methanol \\ $0,25 \%(w / v)$ Coomassie Brilliant Blau R 250 \\ $10 \%(\mathrm{v} / \mathrm{v})$ Eisessig
}

$\underline{\text { Entfärber }}$

$$
\begin{aligned}
& 5 \%(\mathrm{v} / \mathrm{v}) \text { Methanol } \\
& 10 \%(\mathrm{v} / \mathrm{v}) \text { Eisessig }
\end{aligned}
$$

\subsubsection{Silbergel-Färbung von SDS-Polyacrylamidgelen}

Die Färbung von SDS-Polyacrylamidgels mit Silber wird für den Nachweis von sensitiven Proteinbanden verwendet (Shevchenko et al., 2006). Die Fixierung des SDSPolyacrylamidgels erfolgte zweimal für $20 \mathrm{~min}$ in $10 \%$ (v/v) Eisessig mit $40 \%$ (v/v) Ethanol. Anschließend wurde das Gel 30 bis $60 \mathrm{~min}$ in $30 \%$ (v/v) Ethanol mit 0,2 \% (v/v) Natrium-Thiosulfat und 6,8\% (v/v) Natriumacetat schwenkend inkubiert. Sorgfältiges Waschen des Geles mit Wasser führte zur Vorbereitung für die Silberimprägnation. Diese erfolgte für 20 min in einer 0,25 \% (w/v) Silbernitrat-Lösung im Dunkeln. Das Gel wurde dann zweimal jeweils für 1 min mit Wasser gewaschen, bevor es in $0,25 \%(\mathrm{w} / \mathrm{v})$ Natriumcarbonat mit 0,04 \% (v/v) Formaldehyd entwickelt wurde. Die Entwicklung wurde durch eine 1,46 \% (v/v) EDTA-Lösung gestoppt, anschließend wurde das Gel dreimal mit Wasser gewaschen und in $1 \%(\mathrm{v} / \mathrm{v})$ Eisessig und $15 \%(\mathrm{v} / \mathrm{v})$ Ethanol bei $4^{\circ} \mathrm{C}$ gelagert. 


\subsubsection{Western-Blot Analyse}

Für die Immundetektion von Proteinen mit Chemilumineszenz werden diese üblicherweise nach der Trennung mit Hilfe der SDS-PAGE auf eine Nitrozellulose-Membran elektrophoretisch übertragen. Die Semi-Dry-Blot-Methode wurde bereits beschrieben (Towbin et al., 1979). Folgender Aufbau wurde angewendet: Eine Schicht aus einem Filterpapier (Dicke: $3 \mathrm{~mm}$ ), die Nitrozellulose-Membran, das SDS-Gel und wieder einem Filterpapier wurden in Blotpuffer genässt und in dieser Reihenfolge auf die Anodenfläche der Blot-Apparatur luftblasenfrei gelegt. Danach wurde die Kathodenplatte aufgelegt und mit Schrauben fest verschlossen. Nach 1,5 h blotten bei $1 \mathrm{~mA} / \mathrm{cm}^{2}$ Filterpapierfläche wurde die Membran in Ponceau Lösung für ca. 5 min gefärbt, mit destilliertem Wasser entfärbt und die Proteinbeladung sowie die Gleichmäßigkeit des Blotverfahrens kontrolliert. Eventuell wurde der nun sichtbare Größenstandard auf der Membran gekennzeichnet. Um unspezifische Bindungsstellen zu blockieren, wurde die Membran ca. $1 \mathrm{~h}$ mit $5 \%$ (w/v) Milchpulverlösung in TBS inkubiert. Zum Nachweis der Proteine von Interesse wurde die Membran mit dem gewünschten primären Antikörper (Tabelle 4) in 2\%-iger Milchpulverlösung in TBST bei $4^{\circ} \mathrm{C}$ über Nacht oder $2 \mathrm{~h}$ bei Raumtemperatur schwenkend inkubiert. Darauffolgend wurde die Membran nach 3 Waschschritten zu je 5 min mit TBST mit dem jeweiligen HRP-konjugierten Sekundärantikörper für 1,5 h bei Raumtemperatur inkubiert. Nach weiteren drei Waschschritten wurde eine Immundetektion durch Chemilumineszenz mit einem ECL-Kit (Tabelle 6) durchgeführt.

Blotpuffer:

$25 \mathrm{mM}$ Tris-Base (pH 8,3)

192 mM Glycin

$10 \%(\mathrm{v} / \mathrm{v})$ Methanol

Ponceau Lösung:

$5 \%(\mathrm{v} / \mathrm{v})$ Eisessig

$0,25 \%(\mathrm{~W} / \mathrm{v})$ Ponceau $\mathrm{S}$ 
$\underline{\text { TBST }(\mathrm{pH} 7.4):}$

$50 \mathrm{mM}$ Tris-Base $\mathrm{pH} 7.4$

$150 \mathrm{mM} \mathrm{NaCl}$

$0.1 \%(\mathrm{v} / \mathrm{v})$ Tween-20

\subsection{Quantifizierung von Western-Blot Signalen}

Die Signalintensität des Chemilumineszenz-Signals der Western-Blot Analyse wurde mit Hilfe der BioID Software (von Peqlab) quantifiziert. In RIP Experimenten (2.10.2) wurde das Proteinpräzipitat gemessen und ins Verhältnis mit dem poly $(\mathrm{A})^{+}-$Signal, wie z. B. in Dot-Blot-Experimenten (2.8.6) hergestellt, gesetzt. Mindestens drei unabhängige Experimente wurden durchgeführt um den Mittelwert und die Standardabweichung zu bestimmen. Die Signifikanz wurde mit Hilfe des ungepaarten T-Tests des Typs 3 der Microsoft Excel 2010 Software ermittelt.

\subsection{Vorbereitung von Proben für Massenspektroskopische Analysen}

Die Massenspektroskopie (MS) dient als Analyseverfahren zur Bestimmung von unbekannten Protein-Protein-Interaktionen oder zur Untersuchung von Phosphorylierungsstellen innerhalb des gewünschten Proteins (Shevchenko et al., 1996). Aminosäuresequenzen können durch De-Novo-Peptidsequenzierung bestimmt werden. Die zu untersuchenden Peptide, werden in die Gasphase überführt und ionisiert. Die Ionen werden durch ein elektrisches Feld beschleunigt und dem Analysator zugeführt, der sie nach dem Masse-zu-Ladung-Verhältnis m/q „sortiert“ und räumlich in Teilstrahlen auftrennt. Nach Abgleich mit einer Datenbank für S. cerevisiae können die Peptide den entsprechenden Proteinen zugeordnet werden und unbekannte Interaktionen zwischen Proteinen identifiziert werden. Nach Spaltung der Proteine in Peptide mittels einer Protease können diese anschließend massenspektroskopisch vermessen werden. Im Folgenden ist der Standardverlauf eines proteolytischen inGel-Verdaus aufgeführt (Shevchenko et al., 2006). Entweder wurde die gesamte Proteinbande verwendet oder durch Immunpräzipitation wurden spezielle Proteine aufgereinigt und dementsprechend nach einer „Coomassie-Blue“Färbung des SDS-Polyacrylamidgeles die präzipitierten Proteine ausgeschnitten. Die Proteinbanden wurden mit einem Skalpell aus dem Gel ausgeschnitten und in kleine Würfel $\left(1 \mathrm{~mm}^{3}\right)$ zerkleinert und diese in ein Reaktionsgefäß überführt. Zu den Gelstückchen wurden $50 \mu 1$ Acetonitril hinzugegeben, so dass die Gelstückchen mit Flüssigkeit bedeckt waren. 
Nach 10 min Inkubation bei Raumtemperatur wurden die Gelstückchen in einer Speedvac bei $45^{\circ} \mathrm{C}$ für 10 min getrocknet. Im Anschluss wurden $150 \mu 1$ DTT Lösung hinzugegeben und für $1 \mathrm{~h}$ bei $56^{\circ} \mathrm{C}$ inkubiert. Nach Entfernen der DTT Lösung wurden die Gelstückchen mit $150 \mu \mathrm{l}$ der Iodoacetamide Lösung für 45 min bei Raumtemperatur und im Dunkeln inkubiert. Die Lösung wurde von den Gelstückchen wieder entfernt und die Proben wurden mit $150 \mu \mathrm{l}$ Ammoniumhydrogencarbonat I (Tabelle 13) für 10 min bei Raumtemperatur gewaschen. Ein weiterer Waschschritt wurde mit $150 \mu \mathrm{l}$ Acetonitril für $10 \mathrm{~min}$ bei Raumtemperatur durchgeführt, was insgesamt dreimal wiederholt wurde. Zum Schluss wurden die Gelstückchen in der Speedvac bei $45^{\circ} \mathrm{C}$ für 10 min getrocknet. Zum Verdau der Proteine in den Gelstückchen folgte eine Inkubation mit $50 \mu 1$ Trypsinpuffer für 45 min auf Eis. Anschließend wurden $50 \mu \mathrm{l}$ Ammonium-hydrogencarbonat II (Tabelle 13) hinzugefügt und das Reaktionsgemisch wurde über Nacht bei $37^{\circ} \mathrm{C}$ inkubiert. In den weiteren Schritten wurde nun der Überstand gesammelt, da sich in diesem die verdauten Proteine befanden. $\mathrm{Zu}$ den Gelstückchen wurden $50 \mu \mathrm{l}$ Ammoniumhydrogencarbonat III (Tabelle 13) hinzugegeben und 10 min bei Raumtemperatur inkubiert, der Überstand wurde abgenommen und $50 \mu \mathrm{l}$ Acetonitril/Ameisensäure wurden zu den Gelstückchen hinzugegeben. Der Ansatz wurde für 20 min bei Raumtemperatur inkubiert und anschließend wurde der Überstand wieder abgenommen und gesammelt. Dieser Schritt wurde insgesamt dreimal wiederholt und der Überstand immer vereinigt. Im Anschluss wurde der komplette Überstand mit Hilfe der Speedvac bei $50^{\circ} \mathrm{C}$ für $2 \mathrm{~h}$ getrocknet. Abschließend wurde das entstandene Pellet in LC/MS-Solvent (Tabelle 13) gelöst und direkt für die MS-Analyse verwendet. Die Proben wurden anschließend von Dr. O. Valerius aus der Abteilung von Prof. Dr. G. Braus weiterverarbeitet und mittels Orbitrap Velos Pro ${ }^{\mathrm{TM}}$ Hybrid Ion Trap-Orbitrap Massenspektrometer (Thermo Scientific; Schwerte/Deutschland) gemessen. 
Tabelle 13: Lösungen für die Probenvorbereitung zur Messung mittels der MS.

\begin{tabular}{|l|l|}
\hline Beschriftung & Lösung \\
\hline Ammoniumhydrogencarbonat I & $\begin{array}{l}100 \mathrm{mM} \text { Ammoniumhydrogencarbonat, gelöst in } \\
\text { destilliertem Wasser }\end{array}$ \\
\hline Ammoniumhydrogencarbonat II & $\begin{array}{l}50 \mathrm{mM} \text { Ammoniumhydrogencarbonat, gelöst in } \\
\text { destilliertem Wasser }\end{array}$ \\
\hline Ammoniumhydrogencarbonat III & $\begin{array}{l}20 \mathrm{mM} \text { Ammoniumhydrogencarbonat, gelöst in } \\
\text { destilliertem Wasser }\end{array}$ \\
\hline DTT Lösung & $10 \mathrm{mM}$ DTT, gelöst in Ammoniumhydrogencarbonat I \\
\hline Iodoacetamide Lösung & $\begin{array}{l}55 \mathrm{mM} \text { Iodoacetamide gelöst in Ammoniumhydrogen- } \\
\text { carbonat I }\end{array}$ \\
\hline Trypsinpuffer & $\begin{array}{l}25 \mu \mathrm{g} \text { Trypsin gelöst in } 80 \mu \mathrm{l} \text { "Promega resuspension } \\
\text { buffer" und 1:20 verdünnt mit Ammoniumhydrogen- } \\
\text { carbonat II }\end{array}$ \\
\hline Acetonitril/Ameisensäure & $\begin{array}{l}50 \% \text { Acetonitril, } 5 \% \text { Ameisensäure, 45 \% Wasser } \\
97.1 \% \text { Wasser (HPLC) }\end{array}$ \\
\hline LC/MS-Solvent & \begin{tabular}{l}
$2.8 \%$ Acetonitril (HPLC), Ameisensäure, \\
\hline
\end{tabular} \\
\hline
\end{tabular}




\section{Ergebnisse}

\subsection{Bei verschiedenen Stressbedingungen dissoziieren die Adaptor- proteine von der $\operatorname{poly}(\mathrm{A})^{+} \mathrm{RNA}$}

Zur Analyse der Dissoziation der Adaptorproteine Npl3, Nab2, Gbp2, Hrb1, des RNABindeproteins Yra1 und des mRNA-Exportrezeptors Mex67 von der poly(A) ${ }^{+}$RA bei Stress wurden RNA-Co-Immunpräzipitationsexperimente (RIP Experimente) durchgeführt, wobei die Proteine mittels endogen markierten Fusionstag immunpräzipitiert wurden. Im Anschluss wurde die gebundene poly $(\mathrm{A})^{+} \mathrm{RNA}$ aufgereinigt und mit Hilfe von Dot-Blot Analysen untersucht (Abbildung 13). Die GFP- oder myc-Proteintags waren C-terminal an Mex67, Yra1, Nab2, Hrb1 und Gbp2 fusioniert. Eine Ausnahme bildet Npl3, da nur ein Nterminal getaggtes Protein funktional ist. Die Zellen wurden bis zur logarithmischen Phase kultiviert und anschließend in drei Fraktionen aufgeteilt. Eine Fraktion wurde bei $25^{\circ} \mathrm{C}$ kultiviert, sofort geerntet und mit Hilfe flüssigen Stickstoffs schockgefroren. Die Zellen der beiden anderen Fraktionen wurden entweder einem Hitzestress $\left(42^{\circ} \mathrm{C}, 20 \mathrm{~min}\right)$ oder einem Salzstress $\left(1 \mathrm{M} \mathrm{NaCl}\right.$ für $1 \mathrm{~h}$ bei $\left.25^{\circ} \mathrm{C}\right)$ unterzogen. Auch diese Zellen wurden nach dem Ernten ebenfalls sofort eingefroren. Nach Aufschluss der Zellen erfolgte die Präzipitation der GFP- bzw. myc-getaggten Proteine. 80 \% der Präzipitate wurde anschließend die RNA extrahiert und in gleichen Volumina auf eine H-bond ${ }^{+}$Nitrozellulosemembran getropft. Mit Hilfe einer Digoxigenin (DIG)-markierten Oligo-dT $(50)$-Sonde wurde die poly(A) ${ }^{+} \mathrm{RNA}$ durch einen mit einer alkalischen Phosphatase konjugierten sekundären Antikörper detektiert. Als Kontrolle für die erfolgreiche Präzipitation der Proteine wurden parallel $20 \%$ der Proben entnommen, mit einer SDS-PAGE aufgetrennt und nachfolgend mittels Western-Blot Analyse untersucht. 

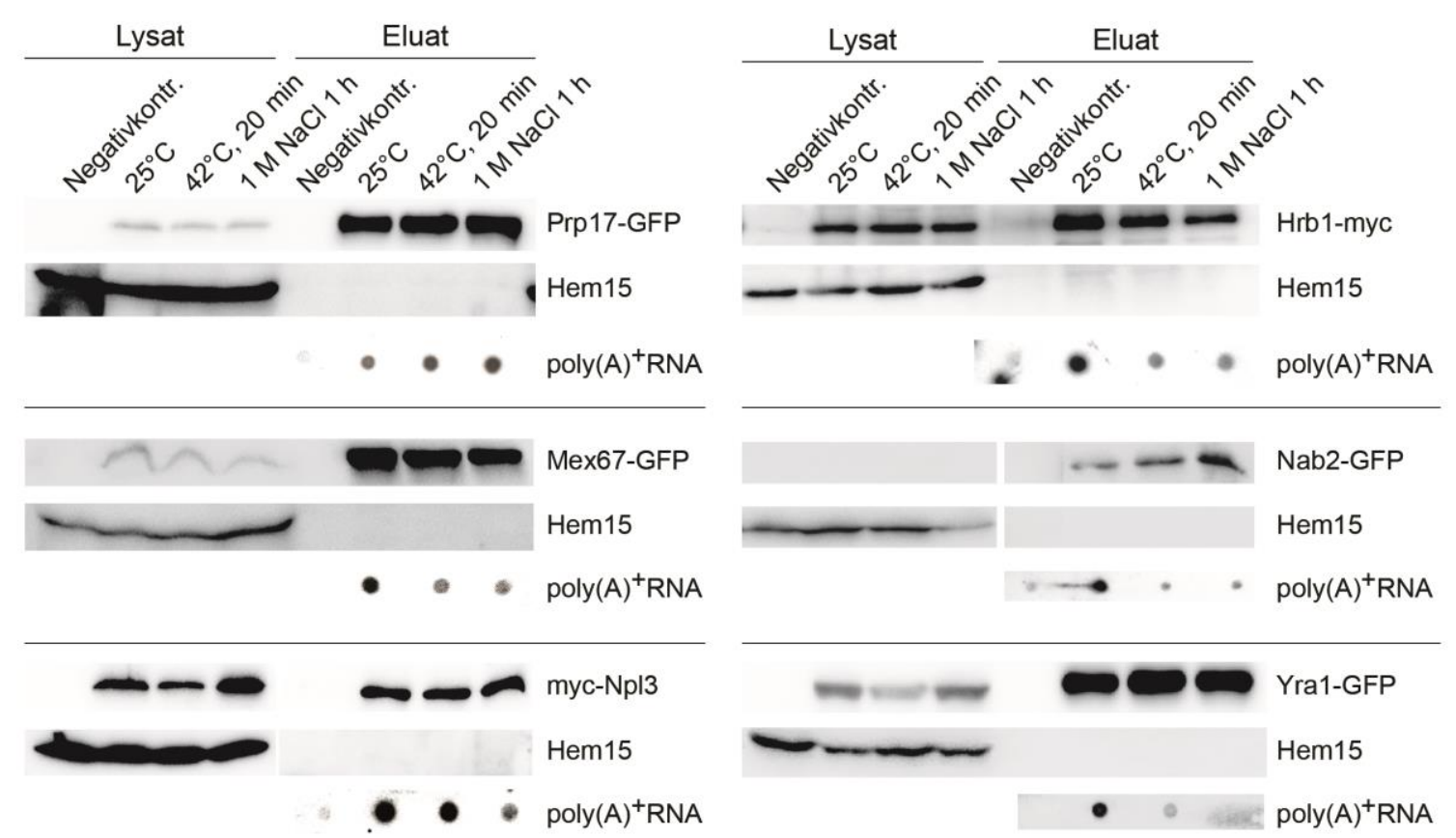

Abbildung 13: Die mRNA-Bindeproteine und Mex67 weisen verringerte poly $(A)^{+}$RNA Bindung bei Stress auf. Logarithmisch wachsende Zellen die endogen jeweils einen GFP- oder myc-Proteinfusionstag an den entsprechenden Proteinen integriert hatten, wurden in drei Teile geteilt. Ein Teil wurde ungestresst bei $25^{\circ} \mathrm{C}$ geerntet, der zweite Teil wurde für 20 min bei $42^{\circ} \mathrm{C}$ einem Hitzestress ausgesetzt und der dritte Teil wurde für $1 \mathrm{~h}$ bei $25^{\circ} \mathrm{C}$ mit $1 \mathrm{M} \mathrm{NaCl}$ versetzt. Nach Zellaufschluss und Immunpräzipitation der Proteinfusionstags wurde die RNA von den Präzipitaten extrahiert und die poly $(\mathrm{A})^{+} \mathrm{RNA}$ mit Hilfe einer DIGgekoppelten Oligo-dT $\mathrm{T}_{(50)}$-Sonde visualisiert. Die Menge an präzipitierten Fusionsproteinen wurde mittels Western-Blot Analyse und Antikörpern gegen GFP, myc und Hem15 kontrolliert. Die RIP mit Prp17-GFP diente als Kontrolle für eine gleichbleibende RNA-Bindung. Weitere Versuchskontrollen wurden als Negativkontrollen verwendet, einerseits die RIP mit einem Zelllysat ohne Fusionsprotein (Negativkontr.) und andererseits die Detektion des mitochondrialen Proteins Hem15.

In der Abbildung 13 sind die RIP Experimente für Mex67 und dessen bindende Proteine Hrb1, Nab2, Np13 und Yra1 sowie eine Positivkontrolle Prp17 zu sehen. Prp17 ist ein später Spleißingfaktor, der am effizienten Spleißprozess der Intron-haltigen prä-mRNAs beteiligt ist. Da bei Stress eine Inhibierung des Spleißprozesses stattfindet (Bracken und Bond, 1999), zeigt Prp17-GFP eine gleichbleibende poly $(\mathrm{A})^{+}$RNA-Bindung bei allen Bedingungen und diente daher als Positivkontrolle. Als Negativkontrolle wurde jeweils ein Hefestamm, der kein Fusionsprotein beinhaltete, verwendet. Während sich die RNA-Bindung von Prp17 bei Stress nicht verändert, zeigen $\mathrm{Hrb} 1, \mathrm{Nab} 2, \mathrm{Npl3}$ und Yra1 eine deutliche Reduktion des poly $(A)^{+}$RNA Signals. Auch bei Mex67 wird eine Abnahme des poly $(A)^{+}$RNA-Signals nach Hitze- und Salzstress im Vergleich zu Zellen ohne Stress detektiert. Anhand der WesternBlot Analysen werden gleichbleibende Proteinsignale nach der Präzipitation der mRNABindeproteine und Mex67 gezeigt. Demnach ist das verringerte poly(A) ${ }^{+}$RNA-Signal nach Hitze- und Salzstress, nicht auf Proteinabbau zurückzuführen sondern bei den verschiedenen 
Stressbedingungen dissoziieren die mRNA-Bindeproteinen und Mex67 von der $\operatorname{poly}(\mathrm{A})^{+} \mathrm{RNA}$.

Bemerkenswerterweise kann Gbp2 in RIP Experimenten nach 20 min Hitzestress nicht mehr immunpräzipitiert werden. Daher wurden verschiedene Zeitpunkte der HitzestressBedingungen durchgeführt und festgestellt, dass das Protein nach 5 min noch löslich und im Überstand zu detektieren ist (Abbildung 14b). Nach bereits 10 min ist Gbp2 jedoch fast vollständig im Zellpellet zu finden und nach 15 und 20 min lässt es sich ausschließlich im Pellet detektieren. Dies lässt sich durch seine Bildung von Super-Aggregaten erklären, (Wallace et al., 2015). Die Autoren zeigten auch, dass die Lokalisation von Gbp2 in den Super-Aggregaten reversibel ist und dass das Protein bei Hitzestress nicht abgebaut wird. (Wallace et al., 2015). Aus diesem Grund wurde das RIP Experiment nach einer kürzeren Stresszeit von 7 min bei $42^{\circ} \mathrm{C}$ durchgeführt (Abbildung 14a).

a

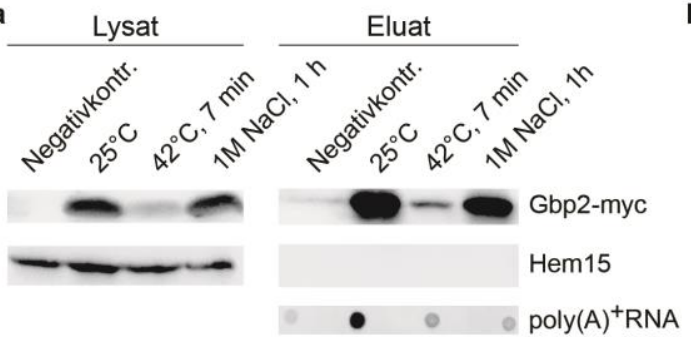

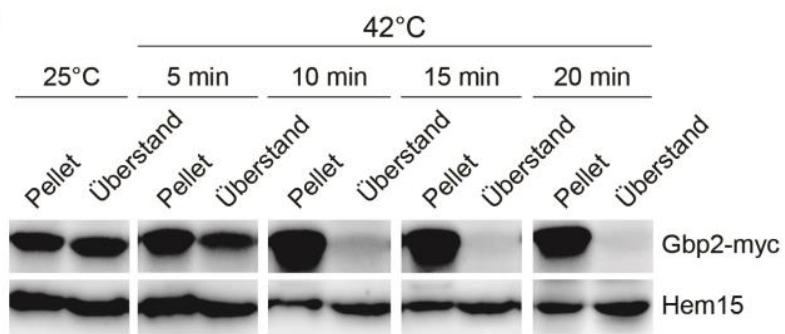

Abbildung 14: Das Mex67-bindende Adaptorprotein Gbp2 dissoziiert bei Stress von der poly(A)+RNA. a, Die RIP Experimente wurden wie in Abbildung 13 durchgeführt, mit Ausnahme des Hitzestresses, der für 7 min durchgeführt wurde. Die, an das präzipitierte Gbp2-myc gebundene, poly $(\mathrm{A})^{+} \mathrm{RNA}$ wurde mit Hilfe von Dot-Blot Analysen und einer DIG-gekoppelten Oligo-d $\mathrm{T}_{(50)}$-Sonde visualisiert. Die Detektion des mitochondrialen Proteins Hem15 diente als Negativkontrolle. B, Die Western-Blot Analyse mit Anti-myc- und Anti-Hem15-Antikörpern zeigt Gbp2-myc im Pellet oder im Überstand nach Zellaufschluss unter normalen Wachstumsbedingungen $\left(25^{\circ} \mathrm{C}\right)$ oder nach einem Hitzestress bei $42^{\circ} \mathrm{C}$ unter den angegebenen Zeitpunkten. Als Ladekontrolle diente Hem15.

Auch bei Gbp2 erkennt man eine deutliche Abnahme der Bindung an die poly $(\mathrm{A})^{+} \mathrm{RNA}$ nach Hitze- und Salzstress. Die Experimente wurden in Abbildung 13 und Abbildung 14 exemplarisch gezeigt, mindestens dreimal voneinander unabhängig wiederholt und als Diagramm dargestellt (Abbildung 15). 


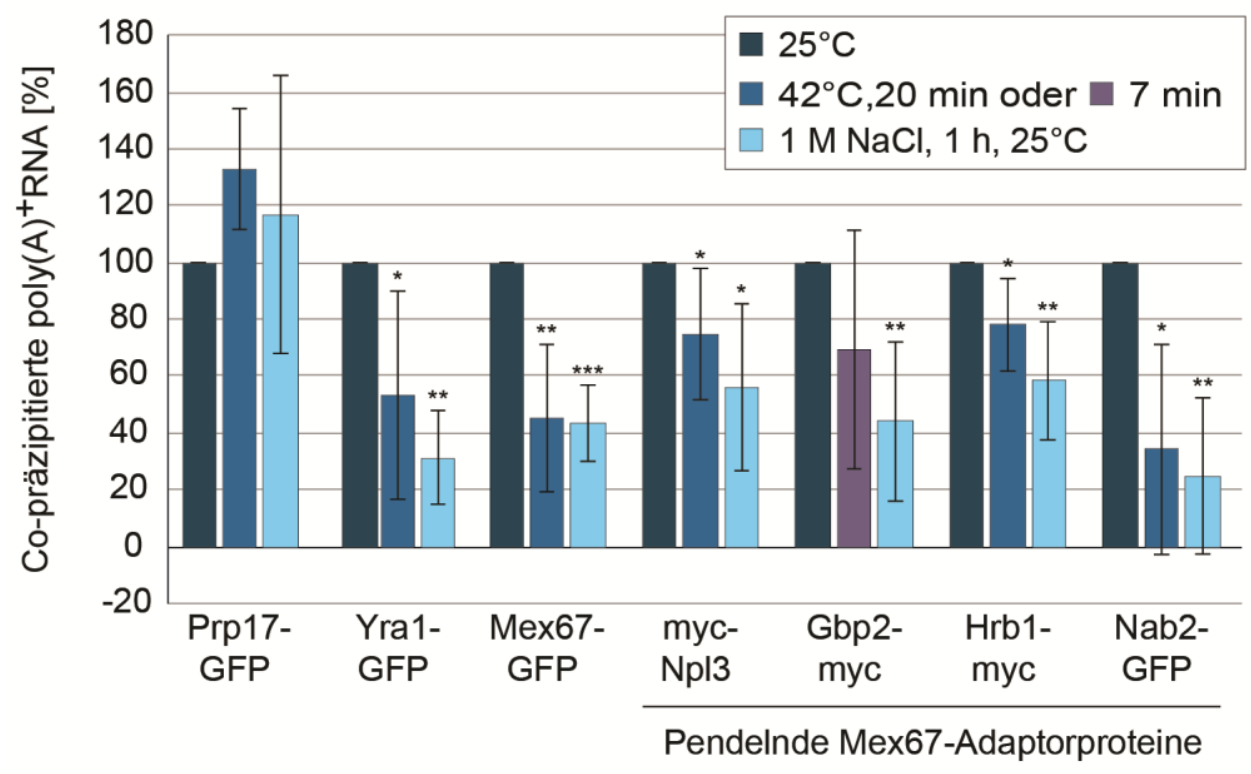

Abbildung 15: Die mRNA-Bindeproteine und Mex67 binden signifikant geringer an poly(A) ${ }^{+}$RA bei Hitze- oder Salzstress. Mindestens drei RIP Experimente aus Abbildung 13 und Abbildung 14 wurden in folgendem Diagramm zusammengefasst. Dabei wurde das Signal aus der poly $(\mathrm{A})^{+} \mathrm{RNA}$ ins Verhältnis zu dem Signal aus der Western-Blot Analyse innerhalb eines Experiments gesetzt und zusätzlich die Stressbedingungen mit dem Zustand bei $25^{\circ} \mathrm{C}$ verglichen. Bei $25^{\circ} \mathrm{C}$ binden $100 \%$ der mRNAs. Im Verhältnis dazu sind die Abweichungen der mRNA-Bindung unter Stress dargestellt. Die Fehlerbalken repräsentieren die Standardabweichung und die angezeigten Signifikanzen (p-Werte) wurden nach dem ungepaarten T-Test (Typ 3) berechnet. $* * *=p<0.001, * *=p<0.01, *=p<0,05$

Die Signalintensitäten der poly(A)+RNA-Detektion wurde mit Hilfe des Bildauswertungsprogrammes „Fiji“ quantifiziert und ins Verhältnis zu den Intensitäten der präzipitierten Proteine aus den Western-Blot Analysen gesetzt. Zudem wurden die berechneten Signalstärken von Hitze- bzw. Salzstress mit denen unter stressfreien Bedingungen $\left(25^{\circ} \mathrm{C}\right)$ verglichen. Entsprechend wurden die Werte ohne Stress $\left(25^{\circ} \mathrm{C}\right)$ auf $100 \%$ gesetzt und die Werte von Hitze- und Salzstress darauf bezogen (Abbildung 15). Während die Positivkontrolle Prp17 keine signifikante Veränderung der poly(A)+RNA-Bindung aufweist, dissoziieren die Adaptoren Np13, Gbp2, Hrb1 und Nab2 von der mRNA. Auch Yra1 und Mex67 werden von der poly(A)+RNA unter Hitze- und Salzstress abgelöst. Die Dissoziation der Exportfaktoren könnte dazu führen, dass die regulären Transkripte nicht mehr in das Zytoplasma transportiert werden und im Zellkern akkumulieren.

Um die Dissoziation der Adaptoren, im Speziellen der SR-Proteine, von der mRNA bei Stress auf eine andere Weise nachzuweisen, wurden Lokalisationsexperimente durchgeführt. Die Lokalisation der SR-Proteine ist nukleär, da der Rücktransport der Adaptorproteine in den Zellkern über den Importrezeptor Mtr10 deutlich schneller erfolgt, 
als der mRNA-vermittelte Export (Hacker und Krebber, 2004). Um die Lokalisation unter Stressbedingungen genauer zu untersuchen, wurden Versionen der SR-Proteine (GFP-Npl3c, Gbp2 $2^{-}$-GFP und $\mathrm{Hrb} 1_{\mathrm{c}}$-GFP) verwendet, deren Importrate verlangsamt sind und sie sich daher gleichmäßig im Zellkern und im Zytoplasma verteilen (Gilbert et al., 2001; Windgassen und Krebber, 2003). Wildtypzellen und die mRNA-Exportmutante rat7-1 wurden mit den entsprechenden Plasmiden für GFP-Np13 $3_{c}$ Gbp2 $2_{c}$-GFP und Hrb $1_{c}-G F P$ transformiert. Alle Stämme wurden bei $25^{\circ} \mathrm{C}$ bis zur logarithmischen Phase kultiviert. Anschließend wurde die Kultur entweder für $30 \mathrm{~min}$ bei $37^{\circ} \mathrm{C}$ oder 15 min bei $42^{\circ} \mathrm{C}$ inkubiert oder für $1 \mathrm{~h}$ bei $25^{\circ} \mathrm{C}$ mit $1 \mathrm{M} \mathrm{NaCl}$ behandelt. Da auch Nährstoffmangel zellulären Stress auslöst, wurden die Zellen außerdem bei $25^{\circ} \mathrm{C}$ für $10 \mathrm{~min}$ in Medium ohne Glukose inkubiert. Nach der jeweiligen Stresssituation wurden die Zellen umgehend mit $4 \%$ Formaldehyd fixiert und für die GFP-Mikroskopie vorbereitet. Als Kontrolle für die Lokalisation der poly(A) ${ }^{+}$RA während der verschiedenen Stressbedingungen wurde in einem parallelen Fluoreszenz in situ Hybridisierungs-experiment (FISH) die poly(A) ${ }^{+}$RNA durch eine Cy3-markierte Oligo-dT-Sonde detektiert (Abbildung 16).

Bei $37^{\circ} \mathrm{C}$ lokalisiert die poly $(\mathrm{A})^{+} \mathrm{RNA}$ des Wildtypstammes im Zytoplasma und bei den Stressbedingungen, sowie in der rat7-1 Mutante vorwiegend im Zellkern. In den Wildtypzellen erkennt man bei $37^{\circ} \mathrm{C}$ ebenfalls eine gleichbleibende zytoplasmatische Verteilung der $\mathrm{SR}_{\mathrm{c}}$-Proteine. Bei den verschiedenen Stressbedingungen sind subzelluläre granuläre Strukturen im Wildtyp zu beobachten, bei denen es sich wahrscheinlich um SGs (,stress granules“) oder PBs (,processing bodies“) handelt (Hoyle et al., 2007; Sheth und Parker, 2003). Im Zytoplasma dissoziieren die regulären mRNAs vom Translationskomplex mitsamt ihren assoziierten Proteinen und werden in den beschriebenen Granulas gespeichert. Unter normalen Wachstumsbedingungen findet man die SR-Proteine ebenfalls an translatierte mRNA gebunden (Windgassen et al., 2004). Des Weiteren wurde bereits gezeigt, dass Gbp2, Hrb1 und Np13 bei Glukosemangel neben einer Zellkernlokalisation auch in zytoplasmatischen SGs lokalisiert sind (Buchan et al., 2008; Mitchell et al., 2013). 
Ergebnisse

\begin{tabular}{|c|c|c|c|c|c|c|c|c|}
\hline & & & typ & & & & & \\
\hline & $\begin{array}{l}37^{\circ} \mathrm{C} \\
30 \mathrm{~min}\end{array}$ & $\begin{array}{l}42^{\circ} \mathrm{C} \\
15 \mathrm{~min}\end{array}$ & $\begin{array}{l}\text { - Glukose } \\
10 \mathrm{~min}\end{array}$ & $\begin{array}{c}1 \mathrm{M} \mathrm{NaCl} \\
1 \mathrm{~h}\end{array}$ & $\begin{array}{c}37^{\circ} \mathrm{C} \\
30 \mathrm{~min}\end{array}$ & $\begin{array}{l}42^{\circ} \mathrm{C} \\
15 \mathrm{~min}\end{array}$ & $\begin{array}{l}\text { - Glukose } \\
10 \mathrm{~min}\end{array}$ & $\begin{array}{c}1 \mathrm{M} \mathrm{NaCl} \\
1 \mathrm{~h}\end{array}$ \\
\hline $\begin{array}{c}\text { poly }(\mathrm{A})^{+} \\
\text {RNA }\end{array}$ & 8 & 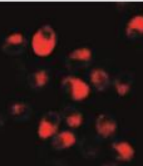 & $\begin{array}{r}328 \\
+0 \\
+\infty\end{array}$ & $i^{*}$ & : & 8 & -6.8 & ${ }^{\infty}{ }^{4}$ \\
\hline
\end{tabular}
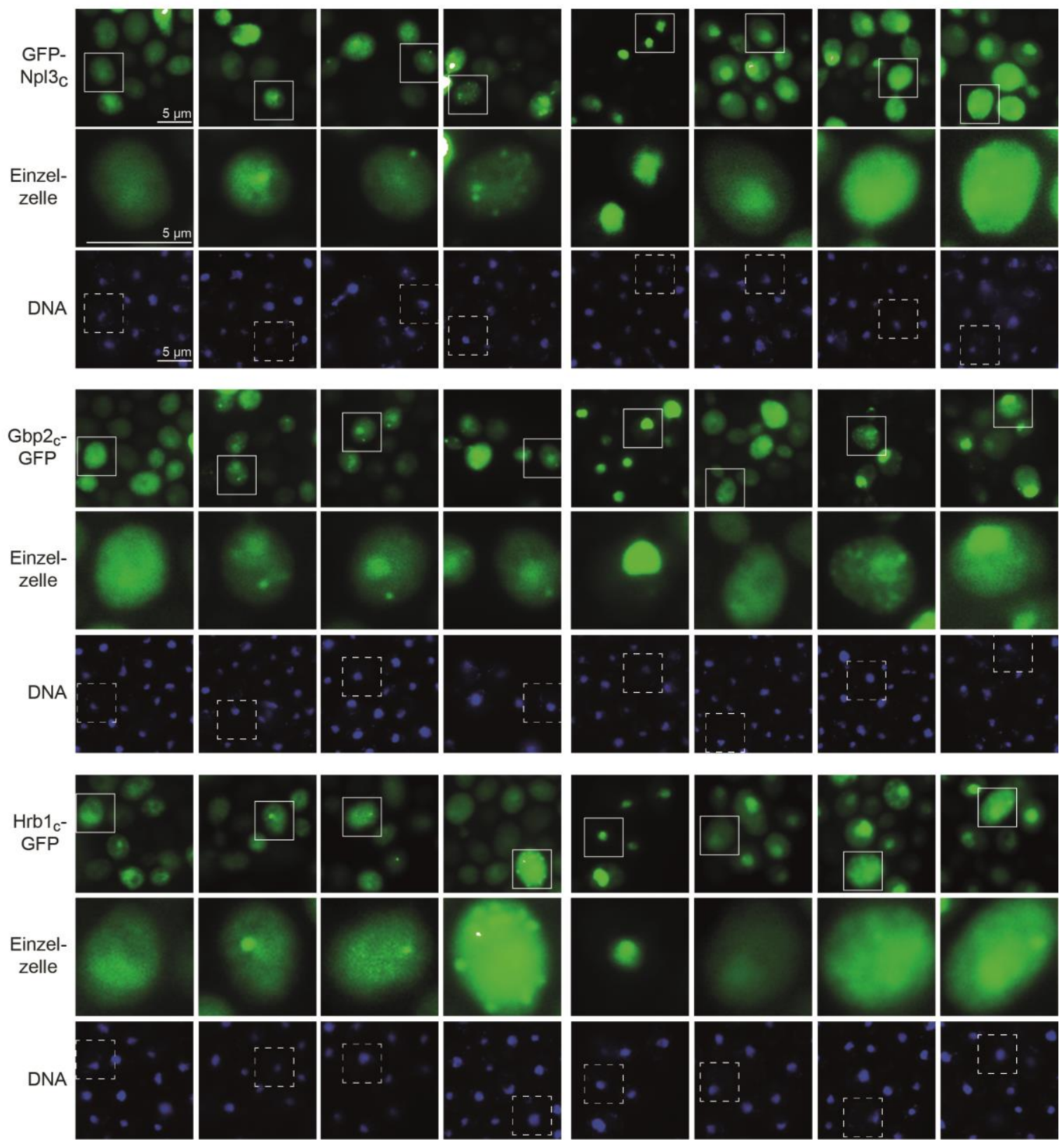

Abbildung 16: Die zytoplasmatischen Versionen der SR-Proteine zeigen bei Stress eine freie und RNAungebundene Diffusion in der Zelle. Wildtypzellen und rat7-1 Mutanten wurden mit den Plasmid-kodierten zytoplasmatischen Versionen für GFP-Npl3c, Gbp2c-GFP und Hrb1c-GFP transformiert und bis zur logarithmischen Phase bei $25^{\circ} \mathrm{C}$ kultiviert. Im Anschluss wurden die Zellen wie abgebildet gestresst und mit Formaldehyd fixiert. Mittels GFP-Mikroskopie wurde die zelluläre Verteilung der GFP-Signale (grün) analysiert. Die DNA wurde mit Hoechst (blau) gefärbt. Als Kontrolle der Verteilung der poly(A) ${ }^{+}$RNA bei Stress wurde diese mittels einer Cy3-gekoppelten Oligo-dT Sonde sichtbar gemacht. 
In den rat7-1 Zellen akkumulieren die $\mathrm{SR}_{\mathrm{c}}$-Proteine bei $37^{\circ} \mathrm{C}$ gemeinsam mit der poly $(\mathrm{A})^{+}$RNA im Zellkern (Abbildung 16). Doch bei den verschiedenen Stressbedingungen ändert sich die cytoplasmatische Lokalisation der $\mathrm{SR}_{\mathrm{c}}$-Proteine im Wildtypstamm und in der rat7-1 Mutante nicht, was darauf hindeutet, dass hier die $\mathrm{SR}_{\mathrm{c}}$-Proteine im Zellkern dissoziieren müssen und dadurch RNA-frei in das Zytoplasma pendeln (Abbildung 16). Bemerkenswert ist auch die Beobachtung, dass in den rat7-1 Zellen eine verringerte Anzahl an Granulas gefunden wurde. Die mRNA scheint fast vollständig im Zellkern zurückgehalten $\mathrm{zu}$ werden, was vermuten lässt, dass bei Stress weniger subzelluläre granuläre Strukturen gebildet werden. Dadurch wird gezeigt, dass die $\mathrm{SR}_{\mathrm{c}}$-Proteine von der mRNA dissoziieren und frei in der Zelle diffundieren.

\subsection{Charakterisierung der Adaptorproteine bei Stress}

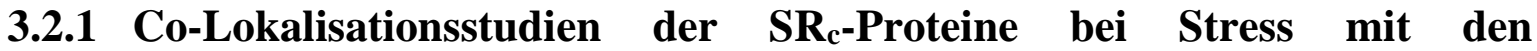 zytoplasmatischen ,stress granules" oder ,P-bodies ${ }^{66}$}

Bei zellulärem Stress werden die regulären RNAs, die sich im Zytoplasma befinden und die nicht an der Stressantwort beteiligt sind, in SGs und PBs gespeichert (Anderson und Kedersha, 2006; Hoyle et al., 2007; Sheth und Parker, 2003).

Unter normalen Wachstumsbedingungen findet man die SR-Proteine Np13, Gbp2 und Hrb1 in Polysomen (Windgassen et al., 2004). Außerdem wurde für Npl3 eine Rolle in der Translationsinitiation beschrieben (Baierlein et al., 2013). Daher stellt sich die Frage, ob die $\mathrm{SR}_{\mathrm{c}}$-Proteine auch im Zytoplasma von der mRNA dissoziieren oder ob sie in SGs oder PBs akkumulieren. Um dies zu untersuchen, wurden Co-Lokalisationsexperimente durchgeführt. Wildtypzellen wurden mit den zytoplasmatischen Versionen der SR-Proteine transformiert, zudem wurde in diese Zellen Konstrukte der Lokalisationsmarker für SGs (Pub1-mCherry) oder für PBs (Edc3-mCherry) eingebracht. Die Kultivierung der transformierten Zellen erfolgte bis zur logarithmischen Phase, anschließend wurden sie Hitze-, Salzstress oder Glukosemangel ausgesetzt und direkt unter dem Fluoreszenzmikroskop analysiert (Abbildung 17). 

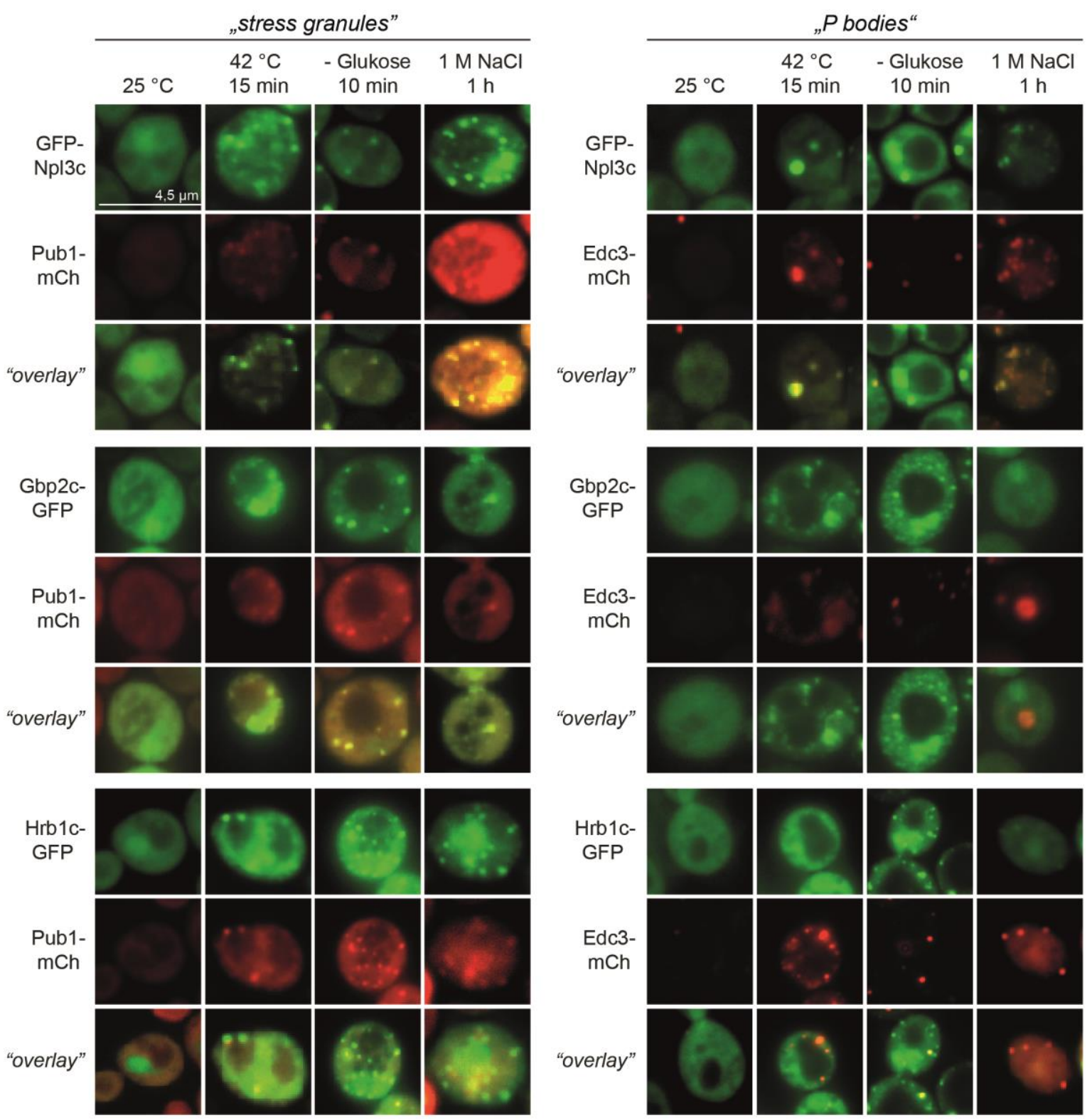

Abbildung 17: Die SRc-Proteine co-lokalisieren mit den Proteinmarkern für „stress granules“ und teilweise für „P-bodies“. Wildtypzellen mit den entsprechenden Plasmiden für die GFP-markierten zytoplasmatischen Versionen der SR-Proteine und für die Markerproteine Pub1-mCherry und Edc3-mCherry wurden bei $25^{\circ} \mathrm{C}$ bis zur logarithmischen Phase kultiviert und verschiedenen Stressbedingungen ausgesetzt: Ohne Stress, Hitzestress $\left(42^{\circ} \mathrm{C}\right.$ für $15 \mathrm{~min}$ ), ohne (-) Glukose (in Medium ohne Glukose für $10 \mathrm{~min}$ ) oder Salzstress $\left(1 \mathrm{M} \mathrm{NaCl}\right.$ für $1 \mathrm{~h}$ bei $\left.25^{\circ} \mathrm{C}\right)$. Anschließend wurden die GFP-SR $\mathrm{c}_{\mathrm{c}}$-Proteine mittels Fluoreszenzmikroskopie auf Co-Lokalisation mit Pub1-mCh oder Edc3-mCh analysiert. Im „overlay“ sind beide Fluoreszenzsignale überlagert, dargestellt.

Alle drei $\mathrm{SR}_{\mathrm{c}}$-Proteine lokalisierten bei Hitzestress, Salzstress oder bei Glukosemangel in Granulas (Abbildung 17 und Mitchell et al., 2013) und co-lokalisierten mit dem SG-Marker Pub1-mCH (Abbildung 17, links). Bei Edc3 als Markerprotein für PB wurde nicht überall eine Übereinstimmung mit dem GFP-Signal der $\mathrm{SR}_{\mathrm{c}}$-Proteine festgestellt (Abbildung 17, rechts). Gbp2 $2_{\mathrm{c}}$-GFP und $\mathrm{Hrb} 1_{\mathrm{c}}$-GFP lokalisierten nicht mit Edc3-mCh in den gleichen 
Granulas. Nur GFP-Npl3 ${ }_{c}$ zeigte eine Co-Lokalisation mit dem Edc3-mCh-Signal vor allem bei Hitze- und Salzstress. Bei Glukosemangel wurden mehr Granulas bei GFP-Npl3c beobachtet, als PBs vorhanden waren. In Publikationen bei denen nur Glukosemangel als Stress verwendet wurde, ließen sich die SR-Proteine bereits in SGs co-lokalisieren (Buchan et al., 2008; Mitchell et al., 2013). In dieser Arbeit wurde weiterhin gezeigt, dass Npl3, Gbp2 und Hrb1 auch bei Hitze- und Salzstress in zytoplasmatischen Granulas gemeinsam mit der regulären mRNAs co-lokalisieren und deshalb vermutlich nicht an der Translation der Stress-spezifischen mRNAs beteiligt sind.

\subsubsection{Die Adaptorproteine werden gemeinsam mit dem Exportrezeptor Mex67 von der regulären poly $(\mathrm{A})^{+} \mathbf{R N A}$ abgelöst}

Zur weiteren Charakterisierung der SR-Proteine und der pendelnden Mex67-bindenden Adaptorproteine wurde die Interaktion von Mex67 mit den Adaptorproteinen Np13, Nab2, Hrb1 und Gbp2 untersucht. Da bereits gezeigt wurde, dass die Proteine bei Stress von der poly $(\mathrm{A})^{+} \mathrm{RNA}$ im Zellkern dissoziieren, sollte nun analysiert werden, ob die Adaptorproteine im Komplex zusammen mit Mex67 abgelöst werden. Dazu wurden die Proteine endogen mit einem GFP-Fusionstag markiert und die Zellen in der logarithmischen Phase geerntet und wieder auf drei Fraktionen aufgeteilt. Die erste Fraktion wurde ohne Stress bei $25^{\circ} \mathrm{C}$ und die beiden anderen Fraktionen wurden entweder einem Hitze- oder einem Salzstress ausgesetzt, geerntet und aufgeschlossen. Unter Zugabe von Rnase A (200 $\mu \mathrm{g} / \mathrm{ml})$ wurden GFP-Npl3 und Nab2-GFP präzipitiert. In Western-Blot Analysen wurde untersucht, ob Mex67 copräzipitiert werden konnte (Abbildung 18).

a

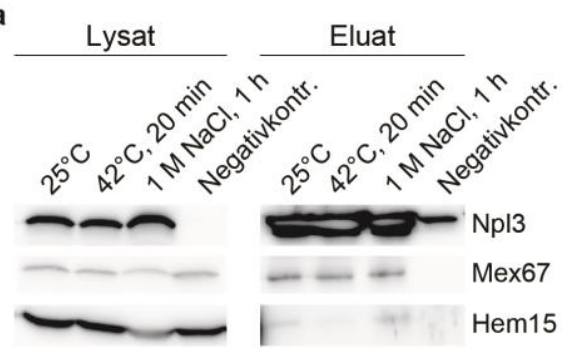

b

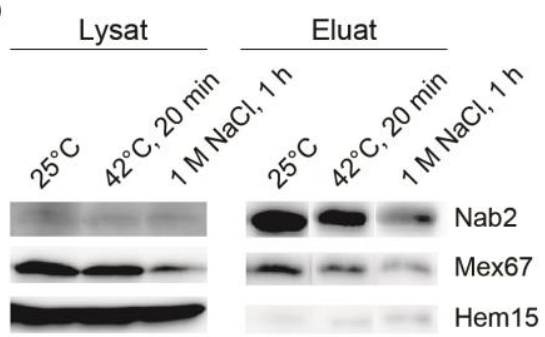

Abbildung 18: Npl3 und Nab2 interagieren in vivo physikalisch mit Mex67 und diese Protein-Interaktion ist RNA- und Stress-unabhängig. Western-Blot Analysen zeigen die Co-Präzipitation von a, Npl3 und b, Nab2 mit Mex67. GFP-Npl3 und Nab2-GFP wurden präzipitiert, gelelektrophoretisch aufgetrennt und in Immunblots mit Anti-GFP-, Anti-Mex67-, Anti-Hem15-Antikörpern analysiert. Durch die Zugabe von RNase A wurde einzelsträngige RNA abgebaut, wodurch RNA-abhängige Interaktionen minimiert wurden. Als Negativkontrolle wurde ein Wildtypstamm ohne endogenen Fusionstag verwendet und die Eluate auf das mitochondrialen Protein Hem15 untersucht. 
In Abbildung 18 ist die Interaktion der Adaptorproteine Npl3 und Nab2 mit Mex67 bei Stress dargestellt. Der Komplex aus Adaptorproteinen und Exportrezeptor bleibt auch während der Stresssituationen bestehen. In weiteren Experimenten konnte G. Zander aus der Arbeitsgruppe von Prof. Dr. H. Krebber ähnliche Interaktionen mit Hrb1 und Gbp2 zeigen, so dass alle pendelnden Mex67-bindenden Adaptorproteine im Komplex zusammen mit Mex67 während Hitze- oder Salzstress nachgewiesen wurden. Es findet also bei zellulärem Stress eine Ablösung des gesamten Komplexes von der poly $(\mathrm{A})^{+} \mathrm{RNA}$ im Zellkern statt. Die Dissoziation der Adaptorproteine von den regulären mRNAs verhindert, dass der mRNAExportrezeptor die regulären mRNAs bei Stress exportieren kann.

\subsubsection{Posttranslationale Modifikationen von Npl3}

Da die Zelle während Stress schnell auf die veränderten Umweltbedingungen reagieren muss, um das Überleben zusichern, ist es wichtig, dass bevorzugt Stress-spezifische Transkripte in das Zytoplasma transportiert werden. Im Zytoplasma werden die StressmRNAs umgehend translatiert und es werden Chaperone hergestellt. Die Chaperone können, die durch den Stress erzeugten falschgefalteten Proteine entweder wiederherstellen oder dem Abbau zuführen. Gleichzeitig werden die regulären mRNAs, durch die Dissoziation der Adaptorproteine und demzufolge auch durch das Ablösen des mRNA-Exportrezeptors, im Zellkern zurückgehalten. In Carmody et al. (2010) konnte gezeigt werden, dass das Adaptorprotein Nab2 bei Hitzestress durch die Serin/Threonin-MAP-Kinase Slt2 phosphoryliert und dadurch vermutlich von der poly $(\mathrm{A})^{+} \mathrm{RNA}$ abgelöst wird.

Durch massenspektroskopische Analysen (MS-Analysen) können posttranlationale Veränderungen von Proteinen detektiert werden. Für Npl3 konnten bereits verschiedene posttranslationale Modifikationen, wie Phosphorylierungen oder Methylierungen gezeigt werden (Shen et al., 1998; Yun und Fu, 2000). Deshalb wurde Npl3 im folgenden Experiment mittels MS-Analysen auf zusätzliche Phosphorylierungen bei Stress hin untersucht. Hierzu wurde ein Deletionsstamm von NPL3 mit einem Plasmid-kodierten GFPNpl3 transformiert und anschließend bis zur logarithmischen Phase bei $25^{\circ} \mathrm{C}$ kultiviert. Die Zellen wurden in 3 Fraktionen geteilt und unterschiedlich behandelt. Eine Fraktion diente als Kontrolle ohne Stress. Die beiden anderen Teile wurden entweder einem Hitzestress $\left(42^{\circ} \mathrm{C}\right.$, für $\left.20 \mathrm{~min}\right)$ oder einem Salzstress $\left(1 \mathrm{M} \mathrm{NaCl}\right.$, bei $25^{\circ} \mathrm{C}$ für $\left.1 \mathrm{~h}\right)$ unterzogen. Nach dem Aufschluss der Zellen wurde das Zelllysat zur Präzipitation von GFP-Npl3 verwendet. Die Proteinbande wurde nach einer SDS-PAGE mit „Coomassie-Blue“ angefärbt und GFP-Npl3 wurde bei $97 \mathrm{kDa}$ ausgeschnitten (Abbildung 19a). 
Die Gelstücke wurden mit Trypsin verdaut und nach dem Protokoll von Shevchenko et al. (2006) aufgereinigt. Es folgte eine Titaniumoxidaufreinigung wodurch besonders Phosphorylierungen angereichert werden sollten. Die finalen Proben wurden dann massenspektroskopisch mittels LTQ-Orbitrap-Hybrid-FT-Verfahren analysiert (durchgeführt von Dr. O. Valerius aus der Arbeitsgruppe von Prof. Dr. G. Braus).
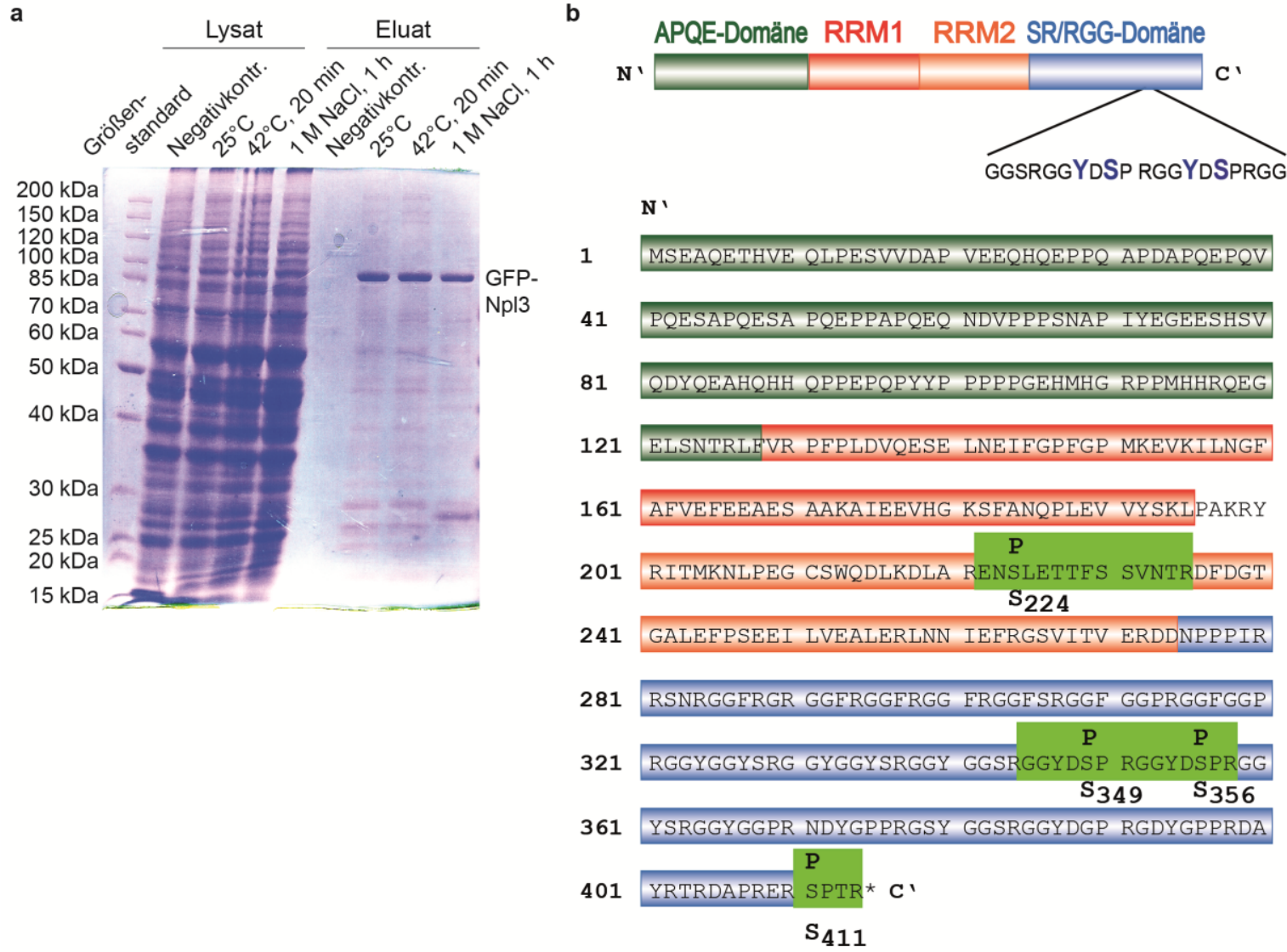

Abbildung 19: Npl3 wird an verschiedenen Aminosäureresten phosphoryliert. Mittels MS-Analyse wurde Np13 auf Phosphorylierungen bei Stress hin untersucht. a, Das dargestellte „Coomassie-Blue“ gefärbte SDSPolyacrylamidgel zeigt GFP-Npl3 bei einer ungefähren Größe von $97 \mathrm{kDa}$. b, In der oberen Illustration ist die Domänenabfolge von Npl3 eingezeichnet. In der SR/RGG-Domäne sind potentielle Stress-induzierte Phosphorylierungsstellen dargestellt. Die untere schematische Darstellung zeigt die Aminosäuresequenz von Np13, dabei sind die möglichen Phosphorylierungsstellen grün markiert, die in der MS-Analyse identifiziert wurden.

Der obere Abschnitt der Abbildung 19b zeigt die einzelnen Domänen von Npl3. Dabei beinhaltet die C-terminale SR/RGG-Domäne eine identische Sequenzwiederholung, welche in der Abbildung 19b hervorgehoben wurde. In der unteren Darstellung der Abbildung 19b ist die Aminosäuresequenz von Npl3 gezeigt und potentielle Phosphorylierungsstellen sind in Grün gekennzeichnet. Die Phosphorylierungsstelle von Npl3 am Serinrest-411 wurde bereits identifiziert und näher charakterisiert (Gilbert et al., 2001). Diese 
Phosphorylierungsstelle wird im Zytoplasma durch die Proteinkinase Sky1 phosphoryliert (Gilbert et al., 2001) und im Zellkern durch die Phosphatase-Aktivität von Glc7 wieder dephosphoryliert. Durch die Dephosphorylierung des Serinrestes-411 kann der mRNAExportrezeptor Mex67-Mtr2 wiederum besser an Npl3 binden (Gilbert und Guthrie, 2004). Durch die Phosphorylierung des Serinrestes-411 im Zytoplasma wird der Rücktransport von Npl3 durch Mtr10 in den Zellkern erleichtert (Gilbert et al., 2001).

Im Fall des Serinrestes-224 wurde diese Phosphorylierung ebenfalls unabhängig von der Stressbehandlung identifiziert. Die MS-Analyse wurde zweimal wiederholt (eine zweite Analyse wurde in der Masterarbeit von A. Schultz durchgeführt) und jedes Mal lag der Serinrest-224 phosphoryliert vor.

Weitere Phosphorylierungen an den Aminosäureresten Serin-349 und/oder Serin-356 wurden vorrangig während Stress identifiziert. Diese potentielle Phosphorylierungen befinden sich in der identischen Sequenzwiederholung (Abbildung 19b). Dadurch ist keine eindeutige Zuordnung zu dem ersten und/oder zweiten Peptid möglich. In der vorliegender Arbeit wurden die ausgeschnittenen Gelstücke mit Trypsin verdaut. Dieses Enzym schneidet nach Lysin- und Argeninresten, wodurch die gezeigte Sequenzwiederholung ensteht (Abbildung 19b). Mit Hilfe dieser MS-Daten wurden zwei verschiedene potentielle Phosphorylierungsstellen an Npl3 nach Stressbehandlung identifiziert, die in weiteren Experimenten verifiziert werden müssen.

An dieser Stelle lässt sich zusammenfassen, dass die Dissoziation der mRNAAdaptorproteine bei Stress wahrscheinlich zum Exportblock der poly(A) ${ }^{+}$RNAs im Zellkern führt. Das Ablösen von der regulären mRNA findet offenbar gemeinsam mit Mex67-Mtr2 im Komplex statt. Im Zytoplasma werden die SR-Proteine zusammen mit den regulären mRNAs vorwiegend in SGs gespeichert. Die Adaptorproteine von Mex67 könnten durch posttranslationale Modifikationen ähnlich zu Nab2 von der regulären mRNA dissoziieren (Carmody et al., 2010). Für Npl3 wurden zwei potentielle Phosphorylierungsstellen identifiziert, die eine solche Dissoziation bewirken könnten. Es stellt sich demnach die Frage, wie die Stress-spezifischen mRNAs in das Zytoplasma exportiert werden. 


\subsection{Analyse der Stress-spezifischen Transkripte}

\subsubsection{Expressionsnachweis der Stress-spezifischen mRNAs}

Im diesem Experiment wurde die Expression der Stress-spezifischen mRNAs analysiert. Dazu wurden Wildtypzellen bis zu einer Zellzahl von 2 x $10^{7}$ Zellen/ml kultiviert, geteilt und anschließend folgenden Behandlungen ausgesetzt: einem Hitzestress ( $42^{\circ} \mathrm{C}$ für $15 \mathrm{~min}$ ) oder einem Salzstress $\left(1 \mathrm{M} \mathrm{NaCl}\right.$ bei $25^{\circ} \mathrm{C}$ für die angegebenen Zeitpunkte). Als Negativkontrolle dienten ungestresste Zellen. Die Zellen wurden lysiert, die Gesamt-RNA extrahiert und die aufgereinigte RNA wurde auf einem $2 \%$-igen Agarosegel aufgetrennt und mit Ethidiumbromid angefärbt (Abbildung 20). Dadurch konnte die Verteilung der 25S, 18S und 5S rRNA untersucht und der Abbau der RNA nach dem angelegten Stress und der Aufreinigung analysiert werden. Die RNA zeigte keinen Abbau (Abbildung 20, Gesamt-RNA) und eine aliqoute Probe wurde deshalb mittels Reverser Transkriptase in cDNA umgeschrieben und anschließend in einer PCR amplifiziert. Als Kontrolle wurde die PCR mit dem Haushaltsgen ACT1 durchgeführt und gezeigt, dass die mRNA Menge auch während Stress gleich blieb und nicht abgebaut wurde. Weiterhin wurden die Transkripte von HSP12 und SSA4 analysiert. Beide mRNAs werden durch Stress induziert, während im Vergleich dazu die $A C T 1$-mRNA konstitutiv exprimiert vorliegt.

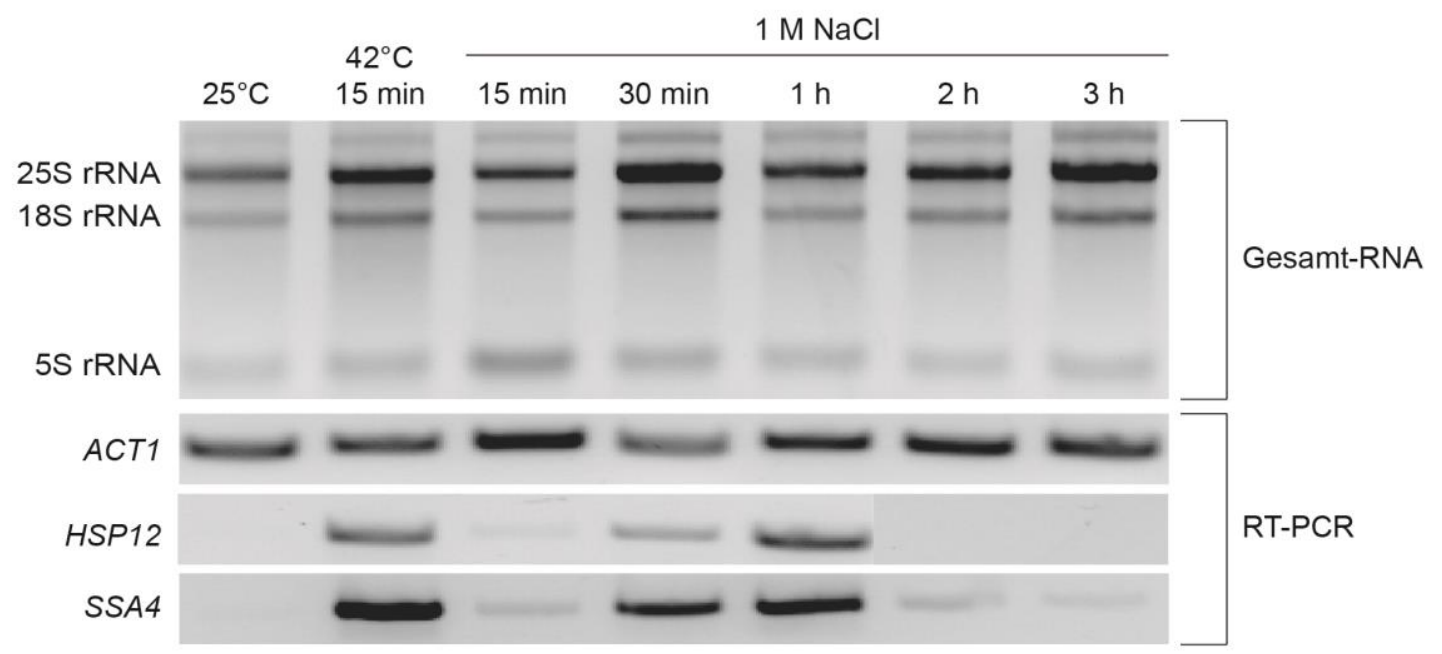

Abbildung 20: Die Stress-spezifischen Transkripte HSP12 und SSA4 werden spezifisch bei Hitze- und Salzstress exprimiert. RT-PCRs zeigen die Expression Stress-spezifischer mRNAs bei Hitze- $\left(42{ }^{\circ} \mathrm{C}\right.$, für $15 \mathrm{~min}$ ) und Salzstress ( $1 \mathrm{M} \mathrm{NaCl}$ bei $25^{\circ} \mathrm{C}$ für verschiedene Zeitpunkte). Als Expressions- und Ladekontrolle ist das Haushaltsgen ACT1 dargestellt.

Bei Hitzestress wurden die Stress-spezifischen Transkripte bereits nach 15 min verstärkt gebildet (Abbildung 20). In weiteren Experimenten wurde der Hitzestress zusätzlich auf 
30 min erweitert, da dies zu einer erhöhten Anreicherung von Stress-spezifischen Transkripten in der Zelle führte. Bei Salzstress waren nach 15 min die ersten Signale sichtbar, dennoch konnte die stärkste Expression für SSA4 und HSP12 nach einer Stunde detektiert werden. Aus diesem Grund wurde in den nachfolgenden Experimenten der Salzstress immer für eine Stunde durchgeführt.

Nach zwei Stunden Salzstress fand eine Adaption der Zelle an den Salzstress statt, so dass keine weiteren Stress-spezifischen Transkripte mehr exprimiert und die bestehenden RNAs abgebaut wurden.

\subsubsection{Mex67-Mtr2, aber nicht die Adaptorproteine sind für den Export der Stress-spezifischen Transkripte verantwortlich}

Bisherige Untersuchungen zeigen, dass Mex67 am Transport der Stress-spezifischen Transkripte in das Zytoplasma beteiligt ist (Saavedra et al., 1997; Sträßer et al., 2000), aber dessen Adapterproteine Npl3, Nab2 und Yra1 nicht notwendig sind (Carmody et al., 2010; Krebber et al., 1999; Rollenhagen et al., 2007). Die Frage, ob die restlichen pendelnden Mex67-bindenden Adaptorproteine am Export der Stress-spezifischen Transkripte beteiligt sind, wurde im Fogenden untersucht. Hierzu wurden Fluoreszenz in situ Hybridisierungsexperimente (FISH) mit spezifischen Digoxigenin (DIG)-gekoppelten Sonden gegen SSA4 und HSP12 in Wildtypzellen, in Mutanten des mRNA-Exportrezeptors mex67-5 oder mtr2-21 und in Deletionsmutanten der pendelnden Adaptorproteine $n p l 3 \Delta$, gbp2 24 und hrb1 $\triangle$ durchgeführt. Da die Deletion von NAB2 ist letal, wurde eine nab2 $\triangle N$ Mutante verwendet.

In Abbildung 21 wurde eine Akkumulation der poly(A)+RNA nach einem 30-minütigen Hitzestress im Zellkern in allen Hefestämmen detektiert. Diese Akkumulation ist jedoch unterschiedlich stark in den verschiedenen Hefestämmen. Während im Wildtyp das poly(A) ${ }^{+}$RNA-Signal zusätzlich im Zytoplasma zu finden war, lokalisiert die poly $(\mathrm{A})^{+} \mathrm{RNA}$ bei mex67-5 und mtr2-21 ausschließlich im Zellkern. Die Mutantenstämme der Adaptorproteine verhielten sich wie der Wildtyp. Auch bei den Signalen der Stressspezifischen Transkripte SSA4 und HSP12 wurde in den Mutanten der Adaptorproteine sowie im Wildtyp keine Anreicherung des Signals im Zellkern festgestellt. Die Stressspezifischen mRNAs zeigten dementsprechend eine gleichbleibende Verteilung des FITCSignals während Hitzestress in den $n p l 3 \Delta$, gbp2 24 , hrb1 $\Delta$ und nab2 $\Delta N$ Zellen sowie in den Wildtypzellen. Im Gegensatz dazu wurde eine Akkumulation der Stress-spezifischen 
mRNAs im Zellkern in den Mutanten des mRNA-Exportrezeptors mex67-5 und mtr2-21 detektiert. Für den Export der Stress-induzierten Transkripte ist also Mex67-Mtr2 erforderlich, nicht aber die Adaptorproteine Np13, Gbp2, Hrb1 und Nab2.

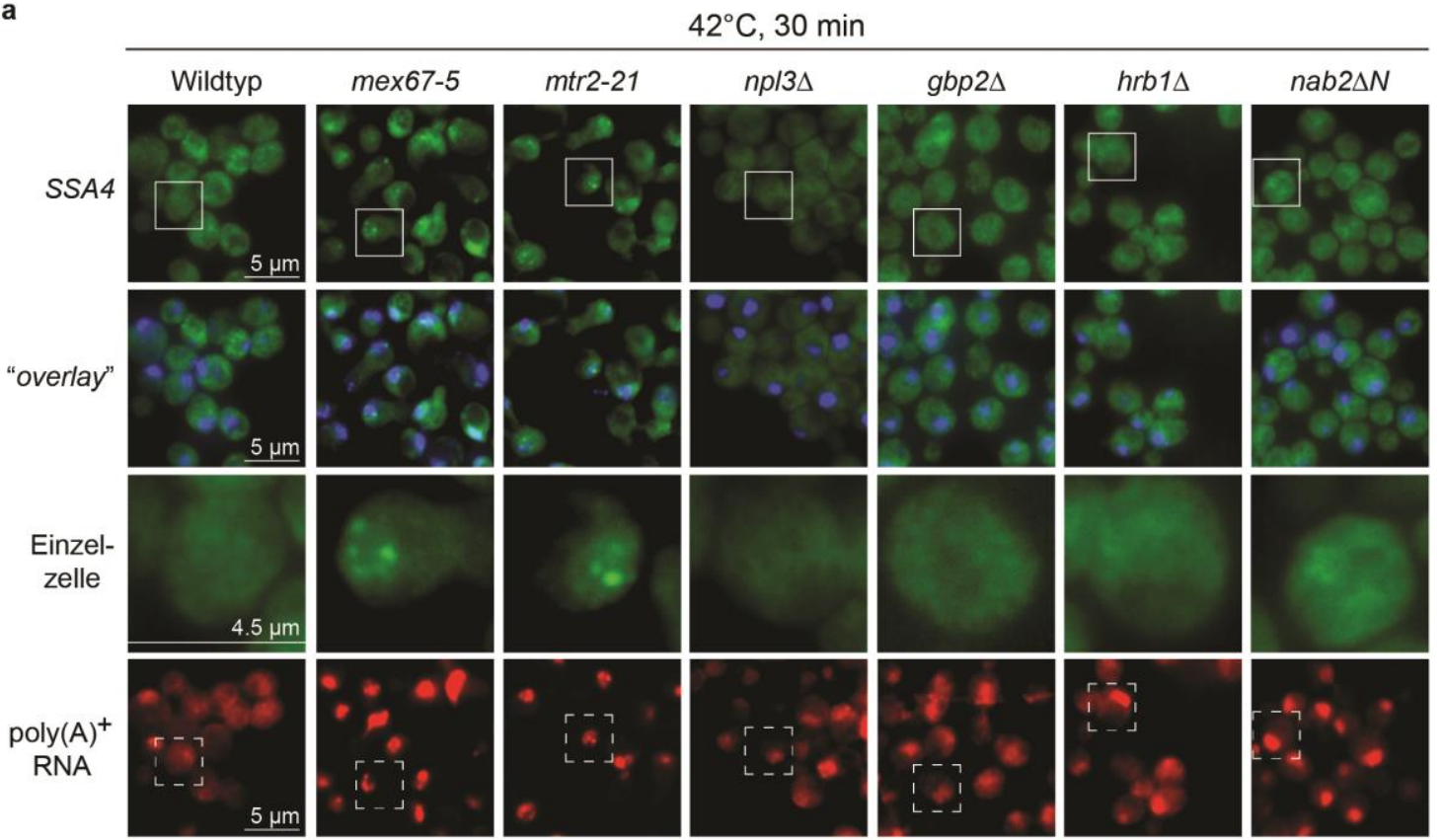

b

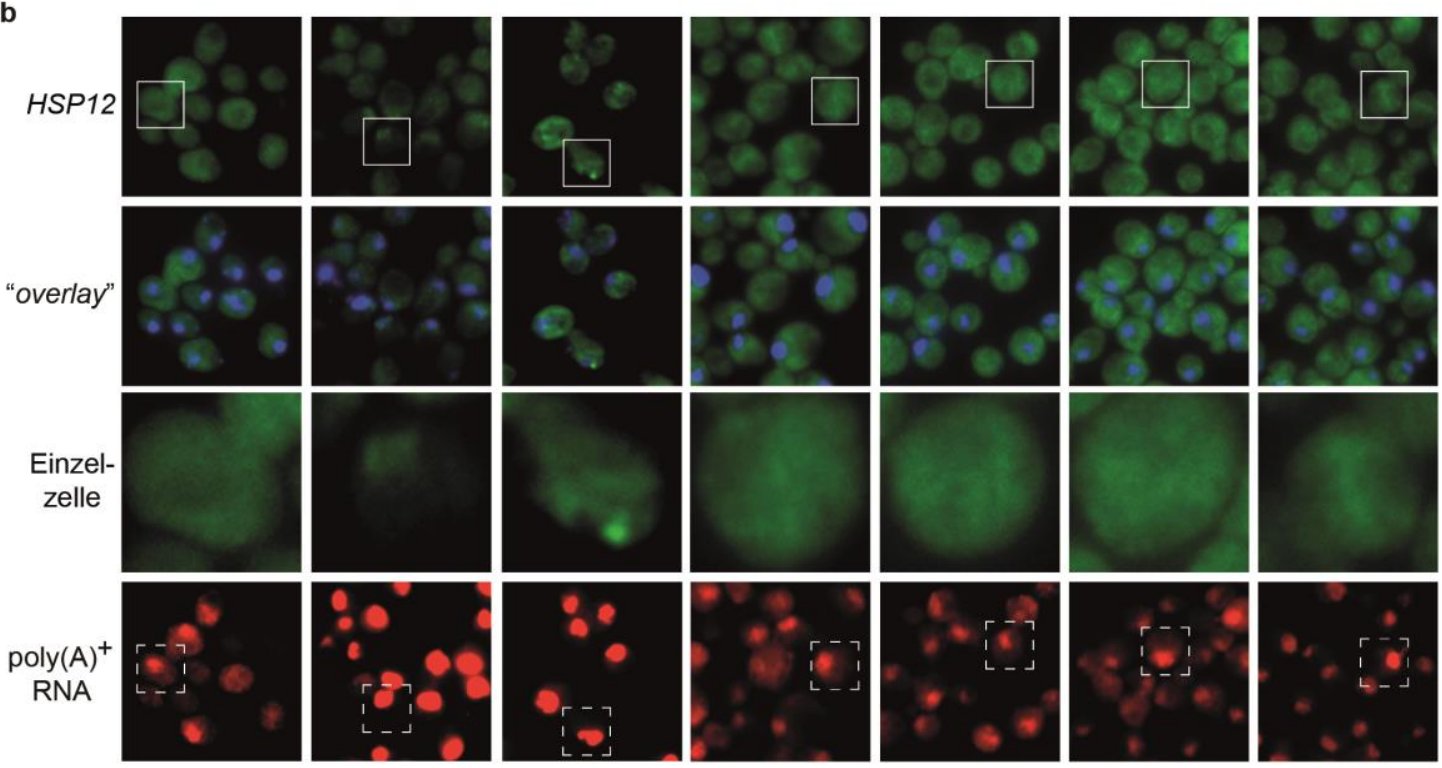

Abbildung 21: Der heterodimere mRNA-Exportrezeptor Mex67-Mtr2, aber nicht seine Adaptorproteine, wird für den Transport von den Stress-spezifischen Transkripten SSA4 und HSP12 benötigt. Mittels FISH Experimenten wurden die Stress-spezifischen mRNAs a, SSA4 und b, HSP12 mit DIGgekoppelten Sonden visualisiert. Die Detektion von poly(A) ${ }^{+} \mathrm{RNA}$ erfolgte über in situ Hybridisierungen mit einer Cy3-gekoppelten Oligo-dT ${ }_{(50)}$-Sonde (rot). Zu sehen ist im „overlay“ das grün-fluoreszierende FITCSignal überlagert mit dem blau-fluoreszierenden Hoechst Signal der DNA. 


\subsection{Untersuchungen von Mex67-Mtr2 unter Stressbedingungen}

\subsubsection{Mex67 bleibt unter Hitzestress an der nukleären Pore lokalisiert}

Da Mex67 am Export von Stress-spezifischen Transkripten beteiligt ist, wurde in einem weiteren Experiment die Lokalisation von Mex67 während eines Hitzestresses überprüft. Hierzu war es schwierig Mex67-GFP mit Hilfe des Standardsprotokolles für die GFPMikroskopie zu detektieren, da Mex67 in geringer Molekülzahl (2830 Moleküle/Zelle) in der Zelle vorliegt (Ghaemmaghami et al., 2003). Die Lokalisationsstudie wurde deshalb ohne fixierende Reagenzien durchgeführt, die das GFP-Signal schwächen. Wildtypzellen mit C-terminal GFP-fusioniertem Mex67, Dbp5 oder Nab2 wurden bis zur logarithmischen Phase kultiviert und anschließend einem Hitzestress bei $42^{\circ} \mathrm{C}$ für die angegebenen Zeitpunkte ausgesetzt (Abbildung 22). Die Zellen wurden sofort mikroskopiert und als Kontrolle diente dabei Nab2-GFP, das bei Hitzestress in „,nuclear foci“ lokalisiert (Carmody et al., 2010).

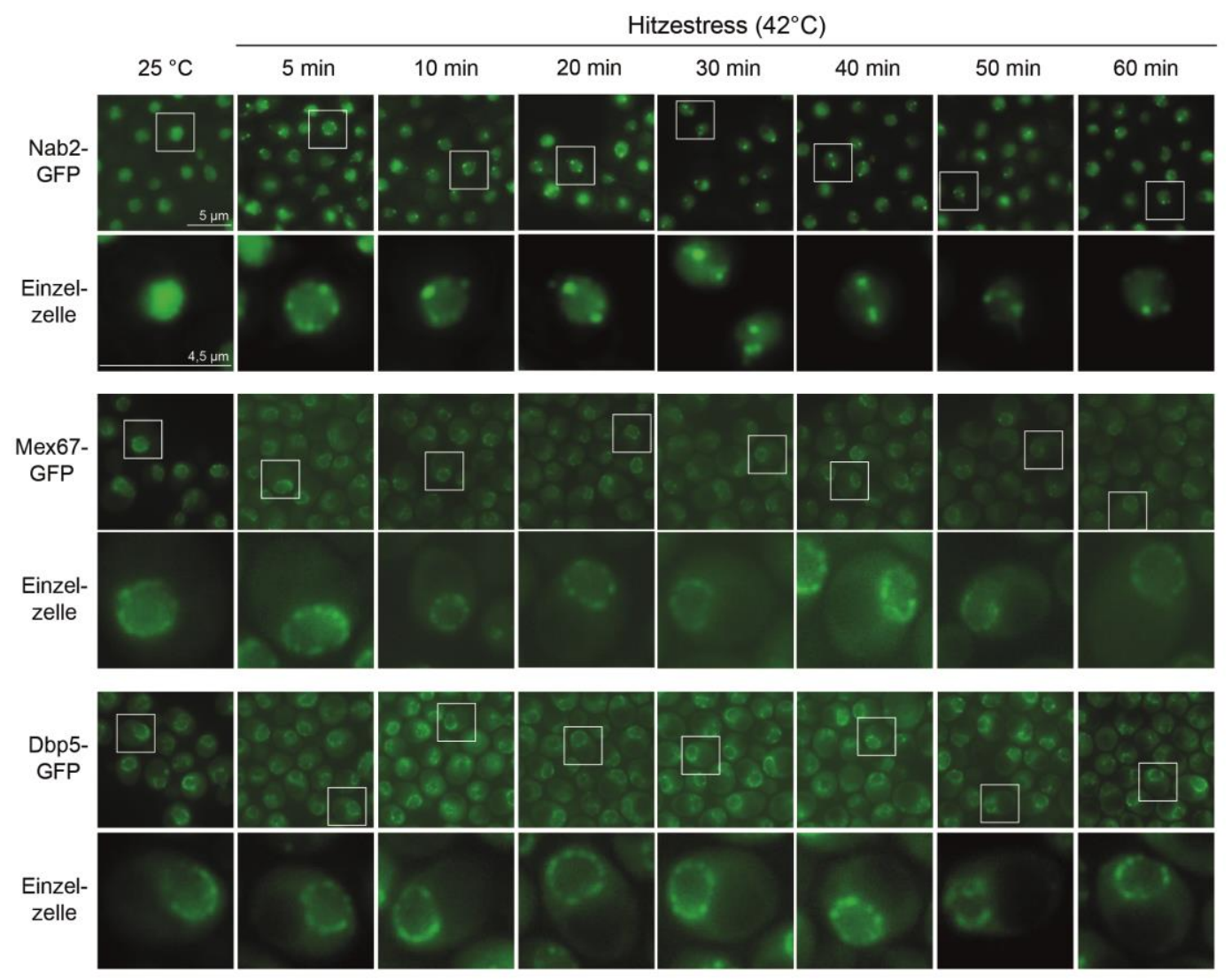

Abbildung 22: Mex67 und Dbp5 bleiben bei Hitzestress am NPC lokalisiert. Die hier dargestellte Abbildung zeigt Nab2-GFP, Mex67-GFP und Dbp5-GFP in lebenden Zellen, die einem Hitzestress bei $42^{\circ} \mathrm{C}$ $\mathrm{zu}$ verschiedenen Zeitpunkten ausgesetzt wurden. 
Nab2 fungierte als Kontrollprotein für den erfolgreichen zellulären Hitzestress und lokalisiert unter normalen Wachstumsbedingungen im Zellkern (Hector et al., 2002) (Abbildung 22). Nach 5 min Hitzestress akkumuliert Nab2-GFP bereits in den beschriebenen „nuclear foci“ (Carmody et al., 2010) (Abbildung 22). Auch nach 60 min Hitzestress lokalisierte Nab2-GFP noch in den ,nuclear foci“. Doch konnte man Nab2-GFP während der ersten 20 min Hitzestress weiterhin im Zellkern detektieren. Da Nab2 gemeinsam im Komplex mit Mex67 (Abbildung 18) von der poly(A) ${ }^{+}$RNA dissoziiert, könnte das nukleoplasmatische Signal möglicherweise dadurch erklärt werden.

Im Gegensatz dazu sind Mex67 und das ebenfalls an der Zellkernhülle lokalisierte Dbp5 (Snay-Hodge et al., 1998) zu jedem Zeitpunkt am NPC zufinden. Zusätzlich konnte für Mex67-GFP bei $25^{\circ} \mathrm{C}$ ein nukleoplasmatisches Signal beobachtet werden, das bei Hitzestress in das Zytoplasma verschoben ist. Die Hauptlokalisation von Mex67 und Dbp5 ist jedoch an der Zellkernhülle, wo sie ihre Funktion am NPC bei Hitzestress im Transport von Stress-spezifischen mRNAs ausüben können.

\subsubsection{Massenspektroskopische Analysen mit Mex67-GFP}

Bei zellulärem Stress bleibt Mex67 am NPC lokalisiert und exportiert die Stressspezifischen mRNAs in das Zytoplasma. In einem weiteren Experiment sollte untersucht werden, ob weitere Proteine mit Mex67 bei Stress interagieren könnten. Hierzu wurde Mex67-GFP massenspektroskopisch analysiert, um unbekannte Protein-Interaktionen bei Hitze- oder Salzstress zu identifizieren. Zellen mit endogenem Mex67-GFP wurden bis zu 2x $10^{7}$ Zellen/ml kultiviert und anschließend in drei Fraktionen aufgeteilt. Eine Fraktion wurde ungestresst geerntet, die zweite Fraktion wurde einem Hitzestress ( 20 min bei $42^{\circ} \mathrm{C}$ ) und die dritte Fraktion wurde einem Salzstress $\left(1 \mathrm{~h}\right.$ bei $25^{\circ} \mathrm{C}$ mit $\left.1 \mathrm{M} \mathrm{NaCl}\right)$ ausgesetzt. Alle Fraktionen wurden geerntet, in flüssigem Stickstoff schockgefroren und anschließend lysiert. Das Zelllysat wurde präzipitiert und $20 \%$ des Präzipitates wurden in einer SDS-PAGE aufgetrennt und mittels Silbergelfärbung visualisiert (Abbildung 23a). Die restlichen $80 \%$ der Proben wurden auf ein weiteres SDS-Polyacrylamidgel aufgetragen und minimal aufgetrennt. Die Gelbanden wurden komplett ausgeschnitten, mit Trypsin verdaut und anschließend aufgereinigt. Die aufgereinigten Peptidstücke wurden für die MSAnalysen (durchgeführt von Dr. O. Valerius aus der Arbeitsgruppe von Prof. Dr. G. Braus) verwendet. 
a

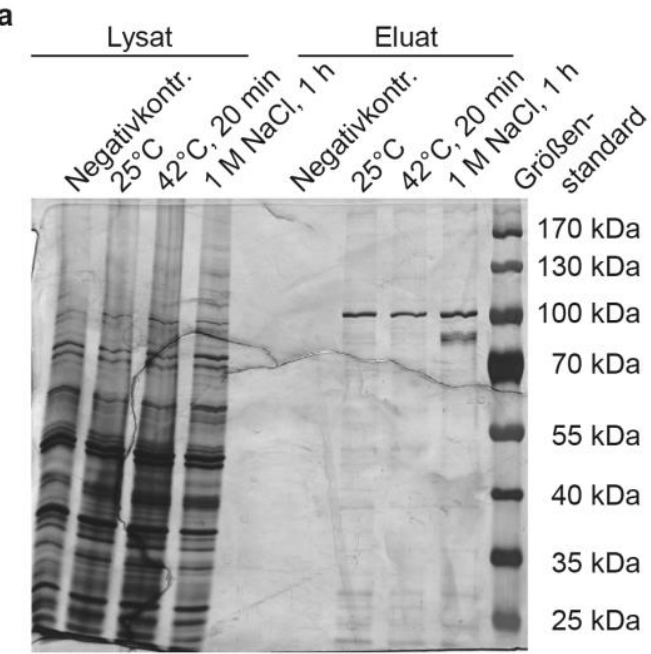

b

Übersicht über Mex67-GFP

interagierende Proteine bei $25^{\circ} \mathrm{C}$

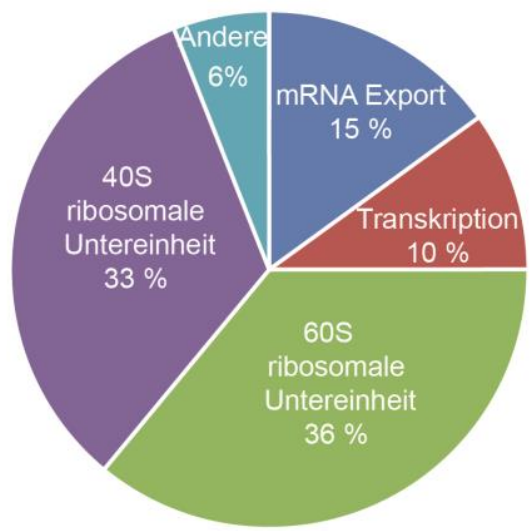

Abbildung 23: Mex67-GFP und dessen interagierende Proteine. A, Wildtypzellen mit endogen exprimierten Mex67-GFP und ohne endogen-exprimiertes GFP (Negativkontrolle) wurden bis zur logarithmischen Phase kultiviert und entweder ungestresst oder nach Stress geerntet. Nach Zellaufschluss wurde Mex67-GFP präzipitiert und $20 \%$ des Präzipitates wurden in einem Silbergel visualisiert. b, Das dargestellte Diagramm zeigt, die mit Mex67-GFP interagierenden Proteine bei $25^{\circ} \mathrm{C}$. Die Proteine wurden in die angegebenen Kategorien eingeteilt.

Die MS-Analyse wurde mit dem Programm „Proteome Discoverer“ (von Thermo Scientific) ausgewertet. Mit Hilfe des Programmes wurden die unterschiedlichen Proben miteinander verglichen und die Anzahl der Peptide und die Sequenzabdeckung des jeweiligen Proteins bestimmt. Bei den Proben, die in der MS-Analyse untersucht wurden, spiegelt die Negativkontrolle die unspezifischen Bindungen von Proteinen an die Matrix wider. Dementsprechend wurden die restlichen Proben (ohne Stress, nach Hitze- und Salzstress) mit der Negativkontrolle verglichen. In Abbildung 23b sind Proteine, die mit Mex67-GFP bei $25^{\circ} \mathrm{C}$ (ohne Stress) interagieren, in einem Diagramm dargestellt. Dabei ließen sich die meisten Proteine in die dargestellten Kategorien einteilen. Entsprechend seiner Funktion beim Export der ribosomalen prä-40S- und prä-60S-Partikel (Faza et al., 2012; Yao et al., 2007), interagieren eine Vielzahl von ribosomalen Proteinen mit Mex67. Da der Exportrezeptor auch für den Export der poly(A)+RNA wichtig ist (Santos-Rosa et al., 1998; Segref et al., 1997), wurden ebenfalls viele Mex67-interagierende Proteine identifiziert, die am Export der mRNA beteiligt sind. Zusätzlich wurden Proteine ermittelt, die in die Transkription involviert sind, da Mex67 vermutlich auch co-transkriptional auf die entstehenden Transkripte geladen werden kann (Hobeika et al., 2007).

Im nächsten Schritt wurden die Stressbedingungen zur Identifikation unbekannter Proteinbindungen analysiert (Tabelle 14). Dabei sind die Mex67-bindenden Proteine nach der Anzahl ihrer identifizierten Peptide bei Salz- oder Hitzestress aufgelistet. 
Ergebnisse

Tabelle 14: Mex67-GFP interagierende Proteine

\begin{tabular}{|c|c|c|c|c|c|c|c|c|c|}
\hline \multicolumn{4}{|c|}{$\begin{array}{c}\text { Anzahl der identifizierten } \\
\text { Peptide }\end{array}$} & \multicolumn{4}{|c|}{ Sequenzabdeckung in [\%] } & \multirow[t]{2}{*}{$\begin{array}{c}\text { Gen } \\
\text { name }\end{array}$} & \multirow[t]{2}{*}{ Kurzbeschreibung } \\
\hline $\begin{array}{l}\text { Negativ } \\
\text { kontr. }\end{array}$ & $\begin{array}{l}\text { Ohne } \\
\text { Stress }\end{array}$ & $\begin{array}{l}\text { Hitze } \\
\text { stress }\end{array}$ & $\begin{array}{c}\text { Salz } \\
\text { stress }\end{array}$ & $\begin{array}{l}\text { Negativ } \\
\text { kontr. }\end{array}$ & $\begin{array}{l}\text { Ohne } \\
\text { Stress }\end{array}$ & $\begin{array}{l}\text { Hitze } \\
\text { stress }\end{array}$ & $\begin{array}{c}\text { Salz } \\
\text { stress }\end{array}$ & & \\
\hline 0 & 0 & 0 & 9 & 0 & 0 & 0 & 37 & GLE2 & Nukleoporin \\
\hline 0 & 1 & 0 & 9 & 0 & 1,2 & 0 & 10,9 & CLU1 & $\begin{array}{l}\text { Untereinheit von } \\
\text { eIF3 }\end{array}$ \\
\hline 1 & 2 & 0 & 7 & 1,9 & 2,5 & 0 & 10,9 & TIF4631 & $\begin{array}{l}\text { Translation- } \\
\text { Initiationsfaktor } \\
\text { eIF4G }\end{array}$ \\
\hline 0 & 0 & 0 & 6 & 0 & 0 & 0 & 7,3 & XRN1 & $5^{\circ}-3^{6}$ Exonuklease \\
\hline 0 & 0 & 0 & 5 & 0 & 0 & 0 & 7 & CBP80 & $\begin{array}{l}\text { nukleäres } \\
\text { Kappenbindeprotein }\end{array}$ \\
\hline 0 & 0 & 0 & 4 & 0 & 0 & 0 & 7,4 & NUP57 & FG-Nukleoporin \\
\hline 0 & 0 & 1 & 3 & 0 & 0 & 1,7 & 8 & $G C D 11$ & $\begin{array}{l}\gamma \text {-Untereinheit des } \\
\text { Translations- } \\
\text { initiationsfaktors } \\
\text { eIF2 }\end{array}$ \\
\hline 0 & 1 & 3 & 0 & 0 & 5 & 13,8 & 0 & SSZ1 & $\begin{array}{l}\text { "ribosome- } \\
\text { associated complex“ } \\
\text { Untereinheit }\end{array}$ \\
\hline 0 & 0 & 3 & 0 & 0 & 0 & 10,5 & 0 & $N A B 2$ & $\begin{array}{l}\text { poly }(\mathrm{A})^{+} \mathrm{RNA}- \\
\text { Bindeprotein }\end{array}$ \\
\hline 0 & 0 & 0 & 3 & 0 & 0 & 0 & 8,9 & $L S G 1$ & $\begin{array}{l}\text { GTPase, } \\
\text { Biogenesefaktor des } \\
\text { 60S-Partikels }\end{array}$ \\
\hline 0 & 0 & 0 & 3 & 0 & 0 & 0 & 4,2 & KRE33 & $\begin{array}{l}\text { Biogenesefaktor des } \\
\text { 40S-Partikels }\end{array}$ \\
\hline 0 & 2 & 0 & 3 & 0 & 9,2 & 0 & 16,1 & RPL11B & $\begin{array}{l}\text { Ribosomales } \\
\text { Protein des 60S- } \\
\text { Partikels }\end{array}$ \\
\hline 0 & 0 & 0 & 3 & 0 & 0 & 0 & 17 & $S B P 1$ & $\begin{array}{l}\text { Protein bindet } \\
\text { eIF4G und } \\
\text { repremiert } \\
\text { Translation }\end{array}$ \\
\hline 1 & 0 & 0 & 3 & 17,4 & 0 & 0 & 29,5 & HTA2 & Histon H2A.2 \\
\hline 2 & 0 & 1 & 2 & 18,3 & 0 & 6,9 & 19,1 & HTB2 & Histon H2B. 2 \\
\hline 0 & 0 & 0 & 2 & 0 & 0 & 0 & 12,3 & YRA2 & RNA-Bindeprotein \\
\hline 0 & 0 & 0 & 2 & 0 & 0 & 0 & 4 & NUP84 & Nukleoporin \\
\hline 0 & 0 & 0 & 2 & 0 & 0 & 0 & 5,4 & $D B P 3$ & $\begin{array}{l}\text { RNA-abhängige } \\
\text { ATPase }\end{array}$ \\
\hline 0 & 0 & 0 & 2 & 0 & 0 & 0 & 6,8 & ASN1 & $\begin{array}{l}\text { Asparagin- } \\
\text { Synthetase }\end{array}$ \\
\hline 0 & 0 & 0 & 2 & 0 & 0 & 0 & 6,4 & YGR054W & $\begin{array}{l}\text { eukaryotischer } \\
\text { Translations- } \\
\text { Initiationsfaktor 2A }\end{array}$ \\
\hline 0 & 0 & 0 & 2 & 0 & 0 & 0 & 4,4 & SSC1 & $\begin{array}{l}\text { Untereinheit der } \\
\text { Hsp70-Familie; } \\
\text { ATPase }\end{array}$ \\
\hline
\end{tabular}




\begin{tabular}{|c|c|c|c|c|c|c|c|c|l|}
\hline 0 & 0 & 0 & 2 & 0 & 0 & 0 & 7 & SUI3 & $\begin{array}{l}\text { l-Untereinheit des } \\
\text { Translations- } \\
\text { initiationsfaktors } \\
\text { eIF2 }\end{array}$ \\
\hline 0 & 0 & 0 & 2 & 0 & 0 & 0 & 3,7 & UBP3 & $\begin{array}{l}\text { Enzym, was } \\
\text { Ubiquitinierungen } \\
\text { von Proteinen } \\
\text { entfernt }\end{array}$ \\
\hline 1 & 1 & 2 & 2 & 9,3 & 9,3 & 16,8 & 24,3 & $R P L 33 B$ & $\begin{array}{l}\text { Ribosomales } \\
\text { Protein des 60S- } \\
\text { Partikels }\end{array}$ \\
\hline 0 & 0 & 2 & 0 & 0 & 0 & 13,6 & 0 & $E F B 1$ & $\begin{array}{l}\text { Translations- } \\
\text { Elongationsfaktor } \\
1 \beta\end{array}$ \\
\hline 0 & 1 & 2 & 1 & 0 & 7,5 & 13,1 & 7,5 & $R P L 16 A$ & $\begin{array}{l}\text { Ribosomales } \\
\text { Protein des 60S- } \\
\text { Partikels }\end{array}$ \\
\hline 0 & 0 & 0 & 2 & 0 & 0 & 0 & 21 & $H S P 26$ & $\begin{array}{l}\text { Hitzeschockprotein; } \\
\text { RNA-Bindeprotein }\end{array}$ \\
\hline 0 & 1 & 1 & 1 & 0 & 3,8 & 3,6 & 3,8 & DED1 & $\begin{array}{l}\text { ATP-abhängige } \\
\text { DEAD-Box-RNA- } \\
\text { Helikase }\end{array}$ \\
\hline 1 & 0 & 0 & 1 & 3,3 & 0 & 0 & 2 & $F U N 12$ & $\begin{array}{l}\text { Translations- } \\
\text { Initiationsfaktor 5B }\end{array}$ \\
\hline 0 & 0 & 1 & 0 & 0 & 0 & 2,7 & 0 & $S S E 1$ & Hitzeschockprotein \\
\hline
\end{tabular}

In rot sind die Gene hervorgehoben, deren Produkte in weiteren Analysen charakterisiert wurden.

Gezeigt sind Proteine, die mit Mex67-GFP interagieren und zusätzlich ist die prozentuale Sequenzabdeckung der identifizierten Proteine gezeigt (Tabelle 14). Diese Methode kann erste Hinweise auf die Bindung von Proteinen mit Mex67-GFP bei Hitze- oder Salzstress liefern, zeigt aber auch, dass Proteine unspezifisch an Mex67-GFP oder an die Matrix binden können. In weiteren Experimenten müssten viele Proteine als tatsächliche Interaktionspartner von Mex67 bestätigt werden.

Neben der Identifizierung von ribosomalen Proteinen, die bei Hitze- und Salzstress an Mex67-GFP binden, konnten bei Salzstress neun Peptide von Gle2 identifiziert werden, die mit Mex67-GFP interagieren. Mit $37 \%$ besaß Gle2 die höchste Sequenzabdeckung in diesem Experiment (Tabelle 14). Gle2 lokalisiert am Kernporenkomplex durch die Interaktion einer konservierten N-terminalen Region von Nup116 der „Gle2-binding sequence“ (GLEBS) (Bailer et al., 1998). Während des Hitzestresses verändert sich die Lokalisation von Gle2 und es kann im Zytoplasma detektiert werden (Izawa et al., 2004). Außerdem zeigten die Autoren, das Gle2 essentiell für die Adaption und den Export der poly $(\mathrm{A})^{+} \mathrm{RNA}$ nach überstandenem Hitzestress ist. Interessanterweise konnten Zellen ohne 
das GLE2 Gen eine erhöhte Salzkonzentration nicht überleben (Regot et al., 2013). In weiteren Experimenten könnte die Interaktion von Mex67 mit Gle2 vorzugsweise bei Salzstress weiter untersucht werden und Analysen, die den Einfluss von Gle2 auf die Stressantwort charakterisieren, durchgeführt werden.

Weitere Mex67-interagierende Proteine, die bei Hitze- und Salzstress identifiziert wurden, sind Translationsfaktoren, wie z. B. Clu1, Tif4631, Gcd11, Sui3, oder Fun12. Diese Interaktionen könnten zeigen, dass Mex67 bei Stress eine Rolle in der Translation spielen könnte und/oder dass es gemeinsam mit den Translationsfaktoren in SGs co-lokalisiert (Mitchell et al., 2013). Weiterhin konnten RNA- oder Protein-abbauende Enzyme identifiziert werden, so z. B. Xrn1 oder Ubp3 (Tabelle 14). Xrn1 ist eine 5'-3' Exonuklease und kann mRNAs nach Entfernung der 7-Methylguanosin-Kappestruktur im Zytoplasma abbauen (Jinek et al., 2011; Larimer und Stevens, 1990). Zusätzlich wurde sie in PBs bei Glukosemangel identifiziert, wo es nach überstandenen Stress, gemeinsam mit dem „,decapping complex“, mRNAs 5'-seitig abbauen kann (Sheth und Parker, 2003). In welchem Kompartiment Mex67-GFP mit Xrn1 interagiert, konnte anhand dieser Methode nicht gezeigt werden, deshalb müssten Interaktionsstudien nach Trennung der Kompartimente und der Granulas wiederholt werden. Außerdem könnten Lokalisiationsstudien zeigen, ob sie in den gleichen Granula-Strukturen (PBs oder SGs) während Salzstress lokalisieren und ob es diesbezüglich Unterschiede zum Glukosemangel gibt (Mitchell et al., 2013).

Überdies wurde bei Hitzestress Ssz1 und bei Salzstress Ssc1 als Interaktionspartner von Mex67 identifiziert. Beide Proteine gehören zur Hsp70-Familie und besitzen eine unterstützende Funktion bei der Translation als ,ribosome-associated complex“ (RAC) (Gautschi et al., 2002; Rakwalska und Rospert, 2004). In weiteren Untersuchungen müsste geklärt werden, ob und wenn ja welche Funktionen diese Proteine bei der Stressantwort und beim Export der Stress-spezifischen mRNAs übernehmen. Zwei weitere Proteine, die als Interaktionspartner von Mex67-GFP identifiziert wurden, sind in der Tabelle 14 hervorgehoben (Dbp3 und Yra2). Diese zwei Proteine sind RNA-Bindeproteine, die bei Stress noch nicht charakterisiert wurden und in dieser Arbeit weiter untersucht wurden.

Außerdem interagiert Mex67-GFP während erhöhter Salzkonzentration mit den Histonen Hta2 und Htb2, was auf eine co-transkriptionale Beladung von Mex67 auf die Stressspezifischen Transkripte hindeuten könnte. Die Interaktion von Mex67 und Nab2 bei Hitzestress wurde bereits bestätigt (Abbildung 18).

Das Protein Hsp26 wurde ebenfalls in der MS-Analyse mit Mex67 interagierend identifiziert (Tabelle 14). Es ist ein RNA-Bindeprotein (Tsvetanova et al., 2010), fungiert als Chaperon 
(Bossier et al., 1989) und liegt im Zytoplasma lokalisiert vor (Thayer et al., 2014). In weiteren Experimenten könnte untersucht werden, welche Rolle Hsp26 als Interaktionspartner von Mex67 spielt.

\title{
3.4.2.1 Charakterisierung von Dbp3 bei Hitze- und Salzstress
}

Dbp3 ist eine RNA-abhängige ATPase und gehört zur Familie der DexD/H-Box Helikasen (Weaver et al., 1997). Sie ist an der Ribosomenbiogenese beteiligt, unterstützt das Herausschneiden des nicht-kodierten IST1-Bereiches an der A3-Schnittstelle während der 35S rRNA Prozessierung und ist für die Reifung der prä-90S Partikels im Nukleolus wichtig. Die ATPase wird durch eine bestimmt Länge von einzelsträngigen Oligonukleotiden aktiviert. Dbp3 zeigt keine Spezifität für rRNA im Vergleich zu anderen RNA-Helikasen, die ebenfalls multiple Bindungsstellen aufweisen (Garcia und Uhlenbeck, 2008). Demzufolge könnte Dbp3 auch mit anderen RNAs in der Zelle interagieren, weshalb verschiedene Experimente durchgeführt wurden, um Dbp3 bei Hitze- und Salzstress zu charakterisieren (Abbildung 24).

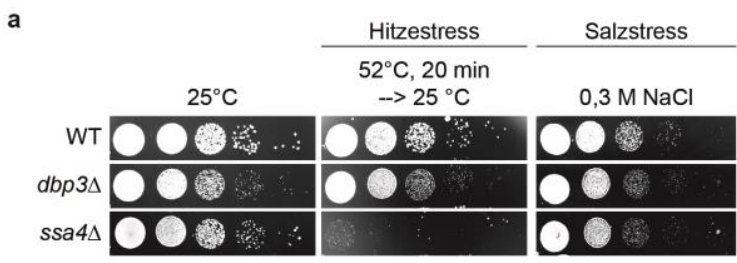

b

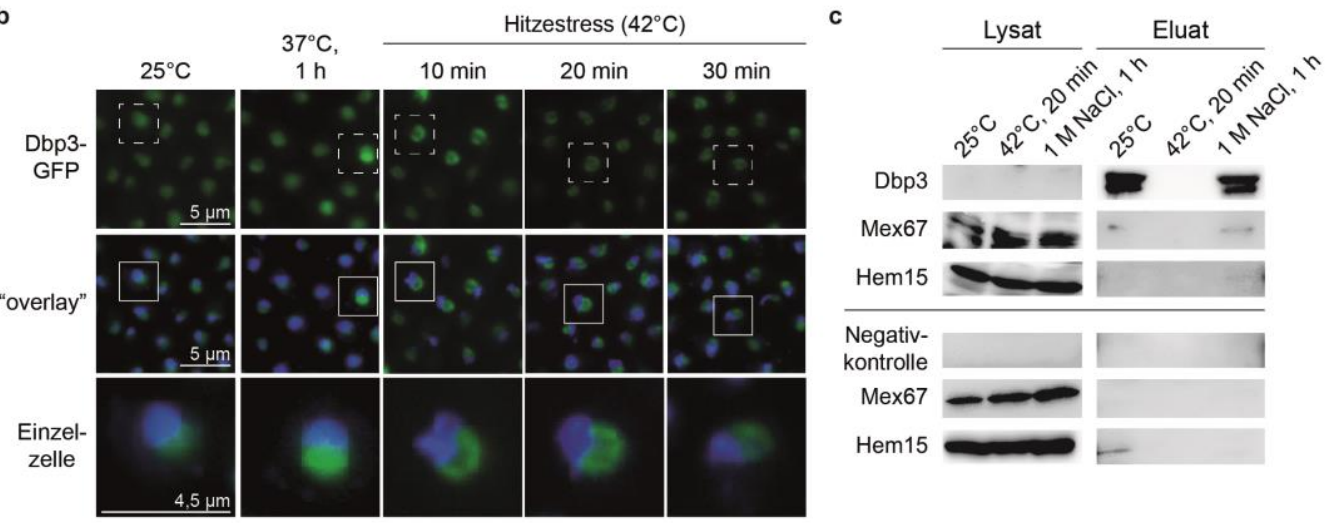

\begin{abstract}
Abbildung 24: Wachstums-, Lokalisations- und Interaktionsstudien mit Dbp3. A, Die Wachstumsanalyse zeigt den Wildtyp (WT) und die Deletionsstämme $d b p 3 \Delta$ und $s s a 4 \Delta$ bei $25^{\circ} \mathrm{C}$ und bei dargestelltem Stress in seriellen Verdünnungen auf Agar-Vollmedium-Platten. B, Lokalisation von Dbp3-GFP bei $25^{\circ} \mathrm{C}, 37^{\circ} \mathrm{C}$ und nach verschiedenen Zeitpunkten bei $42^{\circ} \mathrm{C}$. Die DNA wurde mit Hoechst angefärbt. C, Physikalische Interaktions-Studien von Dbp3-GFP mit Mex67 zeigen eine Interaktion unter Verwendung von Antikörpern gegen GFP, Mex67 und Hem15. Als unspezifische Protein-Interaktionskontrolle dienten Hem15 und Wildtypzellen ohne Dbp3-GFP.
\end{abstract}


Es wurde eine Wachstumsanalyse zur Untersuchung der Überlebensrate des Deletionsstammes von DBP3 nach Hitze- oder Salzstress durchgeführt (Abbildung 24a).

Dabei wurden identische Zellmengen von Wildtypzellen, dbp3 4 und ssa4 Z Zellen mit 1x $10^{5}$ Zellen in serieller Verdünnung auf Agar-Vollmedium getropft. Anschließend wurden die Zellen einem Hitzestress wie folgt ausgesetzt: Die Verdünnungen der entsprechenden Zellen wurden für $20 \mathrm{~min}$ bei $52^{\circ} \mathrm{C}$ inkubiert und im Anschluss direkt auf Agar-Vollmedium getropft. Salzstress wurde ausgeübt, indem eine finale Konzentration von 0,3 M NaCl dem Agar-Vollmedium zugesetzt wurde. Nach zwei Tagen wurde das Wachstum der dbp3A Zellen mit den Wildtypzellen und mit dem Kontrollstamm ssa $4 \Delta$ verglichen. Bei der $25^{\circ} \mathrm{C}$ Kontrollplatte wuchsen alle drei Hefestämme entsprechend gleich (Abbildung 24a). Nach Hitzestress konnte eine deutliche Reduktion des Wachstums der ssa44 Zellen beobachtet werden. Auch bei dem DPB3 Deletionsstamm konnte ein leicht verringertes Wachstum nach Hitzestress festgestellt werden (Abbildung 24a). Im Gegensatz dazu zeigte weder der Kontrollstamm ssa4 $\Delta$ noch $d b p 3 \Delta$ einen Wachstumsdefekt bei 0,3 M NaCl Salzstress. Aus diesem Grund sollte die Analyse mit einer höheren Salzkonzentration wiederholt werden, um das Wachstum der $d b p 3 \triangle$ Zellen bei Salzstress zu untersuchen.

Im nächsten Experiment wurde die Lokalisation von Dbp3-GFP unter Hitzestress untersucht (Abbildung 24b). Wildtypzellen, die Dbp3-GFP endogen exprimierten, wurden bis zur logarithmischen Phase kultiviert und entweder unbehandelt mit $4 \%$ Formaldehyd fixiert oder $1 \mathrm{~h}$ bei $37^{\circ} \mathrm{C}$ inkubiert und anschließend ebenfalls sofort fixiert. Für den erforderlichen Hitzestress wurden die Zellen für $10 \mathrm{~min}, 20 \mathrm{~min}$ oder $30 \mathrm{~min}$ bei $42^{\circ} \mathrm{C}$ inkubiert und sofort fixiert. Wie in Abbildung 24b zu sehen ist, findet eine Lokalisationsänderung bei Hitzestress statt. Bei $25^{\circ} \mathrm{C}$ lokalisiert Dbp3-GFP im Zellkern und im Nukleolus, bei $37^{\circ} \mathrm{C}$ erkennt man Dbp3-GFP verstärkt neben der angefärbten DNA, also vermutlich im Nukleolus. Da Dbp3 für die rRNA-Synthese wichtig ist, erklärt sich die Lokalisation im Nukleolus. Doch während Hitzestress lokalisiert Dbp3-GFP in einer ringartigen Struktur neben dem Zellkern. Diese Lokalisation sieht man auch bei ribosomalen Proteinen bei Hitzestress, wie dies in der Bachelorarbeit von Berfin Tuku aus der Arbeitsgruppe von Prof. Dr. H. Krebber bereits gezeigt wurde. Auch Hsp26 und die SSA4-mRNA zeigen sich in ringartigen Strukturen neben dem Zellkern bei Hitzestress (Daten nicht gezeigt). Für weitere Untersuchungen sollte Dbp3 mit Nop1 und einer Stress-spezifischen mRNA in Co-Lokalisationsexperimenten bei Hitzestress analysiert werden. 
Des Weiteren wurden Interaktionsstudien von Dbp3-GFP mit Mex67 durchgeführt, um die identifizierte Interaktion bei Salzstress nachzuweisen (Tabelle 14; Abbildung 24c) Bei Bedingungen ohne Stress kann man eine schwache Interaktion von Dbp3-GFP mit Mex67 erkennen (Abbildung 24c), da beide Proteine am Ribosomentransport beteiligt sind, könnte darüber eine RNA-abhängige Interaktion stattfinden. Bei Salzstress zeigt sich die schwache Interaktion etwas stärker, das könnte auf eine weitere Funktion von Dbp3 bei Stress in Kombination mit Mex67 hindeuten. Bei Hitzestress kann Dbp3-GFP nicht präzipitiert werden. Eine Erklärung hierfür könnten die ringartigen Strukturen sein, die offenbar nicht mehr löslich im Überstand sind, sondern im Zellpellet sedimentieren. Diesbezüglich könnten Western-Blot Analysen durchgeführt werden (ähnlich wie bei Gbp2 - Abbildung 14a), zur Untersuchung ob Dbp3 im Zellpellet oder im Überstand zu detektieren ist.

\subsubsection{Untersuchungen von Yra2 bei Hitze- und Salzstress}

Ein weiteres Protein, das bei der massenspektroskopischen Analyse von Mex67-GFP unter Salzstress identifiziert wurde, ist Yra2. Dieses Protein gehört zur Familie der REF (RNAund Exportfaktor-bindenden Proteinen) (Zenklusen et al., 2001). Es ist durch eine Genduplikation von Yra1 entstanden und kann, wenn es überexprimiert wird, die Beladung von Mex67 auf die poly(A) RNA im Zellkern übernehmen (Zenklusen et al., 2001). Verschiedene Experimente wurden durchgeführt um Yra2 bei Hitze- und Salzstress zu charakterisieren. Mittels Wachstumsanalyse wurde untersucht, ob das Fehlen von YRA2 im Genom einen Einfluss auf die Stressantwort und dementsprechend auf das Wachstum der Hefezellen unter Hitze- oder Salzstress hat (Abbildung 25a). Ähnlich wie unter 3.4.2.1 wurde eine serielle Verdünnung von Wildtypzellen, ssa44 und yra24 Zellen auf AgarVollmedium ohne Stress, nach Hitzestress und auf Platten mit 0,3 M NaCl durchgeführt. 
a

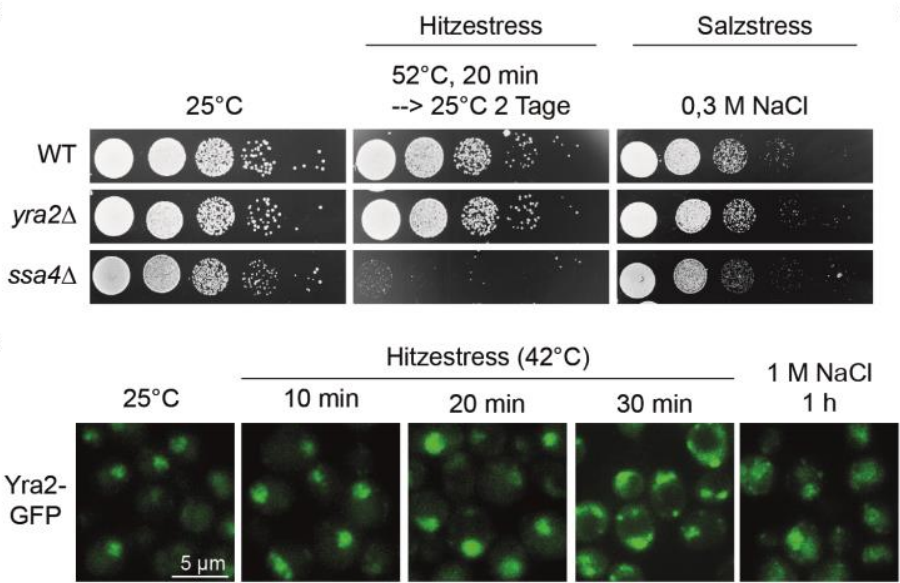

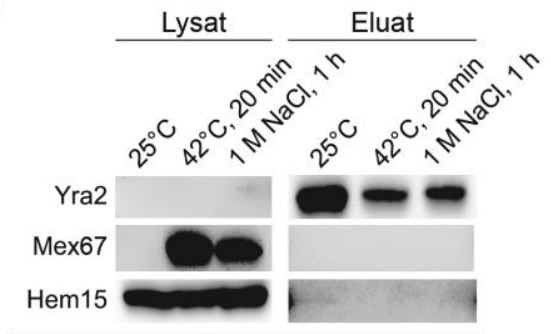

Negativ-

kontrolle

Mex67

Hem15

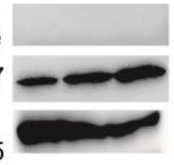

Abbildung 25: Yra2 hat keinen Einfluss auf die Stressantwort bei Hefezellen. A, Die Wachstumsanalyse wurde in seriellen Verdünnungen von Wildtyp (WT), dbp3 4 und ssa4 4 Zellen auf Agar-Vollmedium-Platten bei $25^{\circ} \mathrm{C}$ und nach angezeigtem Stress durchgeführt. B, Mittels Fluoreszenzmikroskopie wurde Yra2-GFP ohne fixierende Reagenzien bei $25^{\circ}, 42^{\circ}$ und bei Salzstress von $1 \mathrm{M} \mathrm{NaCl}$ analysiert. c, Physikalische Interaktionsstudien von Yra2-GFP mit Mex67 zeigten keine Protein-Protein-Interaktionen an. Verwendet wurden Antikörper gegen GFP, Mex67 und Hem15 und als unspezifische Protein-Interaktionskontrolle dienten Wildtypzellen ohne Yra2-GFP und Hem15.

Wie die Wachstumsanalyse zeigt, hat das Fehlen des YRA2 Genes keinen Einfluss auf das Wachstum bei Hitzestress oder Salzstress (Abbildung 25a). Weiterhin wurde Yra2-GFP mittels Fluoreszenzmikroskopie in lebenden Zellen bei Hitzestress und Salzstress lokalisiert (Abbildung 25b). Yra2 ist unter normalen Wachstumsbedingungen in der Zelle sehr gering exprimiert und lokalisiert im Zellkern. Nach 10 min und 20 min Hitzestress bei $42^{\circ} \mathrm{C}$ und nach Salzstress wird Yra2-GFP weiterhin im Zellkern detektiert, doch nach dreißigminütigem Hitzestress (bei $42^{\circ} \mathrm{C}$ ) wird Yra2-GFP zusätzlich in Granulas im Zytoplasma lokalisiert. Um nachzuweisen, dass es sich um zytoplasmatische granuläre Strukturen handelt, könnte in einem folgenden Experiment eine Co-Lokalisationsstudie mit einem Markerprotein (z. B. mit Pub1) für SGs oder für PBs (Edc3) durchgeführt werden. Im nächsten Schritt wurde die Proteininteraktion von Mex67 mit Yra2-GFP untersucht (Abbildung 25c). Yra2-GFP wurde ohne Stress, nach Hitze- und Salzstress präzipitiert und mittels Western-Blot Analysen auf die Interaktion mit Mex67 hin untersucht. Es konnte keine physikalische Interaktion zwischen Yra2-GFP und Mex67 gezeigt werden. Bisherige Ergebnisse zeigen keinen Einfluss von Yra2 auf die Stressantwort in Hefezellen. Deshalb müssten weitere Experimente durchgeführt werden, um eine Funktion von Yra2 bei Salzstress zu bestätigen. 
Außerdem können noch Untersuchungen zu weiteren Proteinen durchgeführt werden, die in der MS-Analyse identifiziert wurden. Interessante Kandidaten wären auch Hsp26, Gle2, Ubp3, Ssz1 oder Ssc1. Diese Proteine besitzen zusätzliche Funktionen bei Stress oder sind Stress-sensitiv (Craig et al., 1989; Haslbeck et al., 2005; Huang et al., 2005; Hundley et al., 2002; Izawa et al., 2004; Regot et al., 2013; Solé et al., 2011; Yamamoto et al., 2005).

\subsubsection{Die Herstellung eines MSIIL-Konstruktes zur Untersuchung von Proteinbindungen an Stress-spezifische mRNAs}

Im weiteren Verlauf dieser Arbeit wurde die Bindung von Proteinen an eine Stressspezifische mRNA in lebenden Zellen untersucht. Dazu wurde eine Haarnadelstruktur (,stemloop“) des Bakteriophagen MS2 an das 3'-Ende des ORFs der HSP12-mRNA kloniert. Diese Haarnadelstruktur wird von dem Protein MS2CP (,MS2 coating protein“) erkannt und gebunden (Slobodin und Gerst, 2010). Durch Fusion des MS2CP mit einem ProteinA-Tag und einem His-Tag kann das mRNA-MSIIL-Konstrukt in zwei Schritten spezifisch aufgereinigt werden. Für die Herstellung der HSP 12-2xMSIIL-mRNA wurden der ORF von HSP12 und der Gen-eigene Promotor in einen Vektor integriert, der bereits eine zweifache „stemloop“ (MSIIL)-Sequenz enthielt. Nach Transformation des Deletionsstammes von HSP12 mit dem HSP12-2xMSIIL-Konstrukt wurde eine Wachstumsanalyse durchgeführt (Abbildung 26a). Dabei wurde das Wachstum von Wildtypzellen mit hsp124 Zellen, die einen Vektor ohne das HSP12 Gen $(+p)$ und einen Vektor mit dem HSP12$2 x M S I I L$-Konstrukt $\left(+p P_{H S P 12}-H S P 12-2 x M S I I L\right)$ integriert hatten bei $25^{\circ} \mathrm{C}$ und nach Hitzestress $\left(52^{\circ} \mathrm{C}, 20 \mathrm{~min}\right)$ verglichen. In einem weiteren Experiment wurde die Expression der mRNA durch eine RT-PCR nachgewiesen (Abbildung 26b) und die Lokalisation der HSP12-2xMSIIL-mRNA wurde mit Hilfe von FISH Experimenten und einer spezifischen Sonde gegen die MSIIL-Sequenz überprüft (Abbildung 26c). Wildtypzellen, ohne Konstrukt, hsp12A Zellen mit HSP12-2xMSIIL-Konstrukt und rat7-1 Zellen mit HSP12-2xMSIILKonstrukt wurden bis zur logarithmischen Phase kultiviert, anschließend wurden die Zellen für $30 \mathrm{~min}$ bei $37^{\circ} \mathrm{C}$ inkubiert oder einem Hitzestress $\left(42^{\circ} \mathrm{C}\right.$ für $\left.30 \mathrm{~min}\right)$ oder einem Salzstress ( $1 \mathrm{M} \mathrm{NaCl}$ für $1 \mathrm{~h}$ bei $25^{\circ} \mathrm{C}$ ) ausgesetzt. Die Proben wurden mittels Fluoreszenzmikroskopie auf die Expression des HSP12-2xMSIIL-Konstruktes hin untersucht, wobei die mRNA-Exportmutante rat7-1 als Kontrolle für den Exportblock der HSP12-2xMSIIL-mRNA im Zellkern diente (Abbildung 26c). 
a

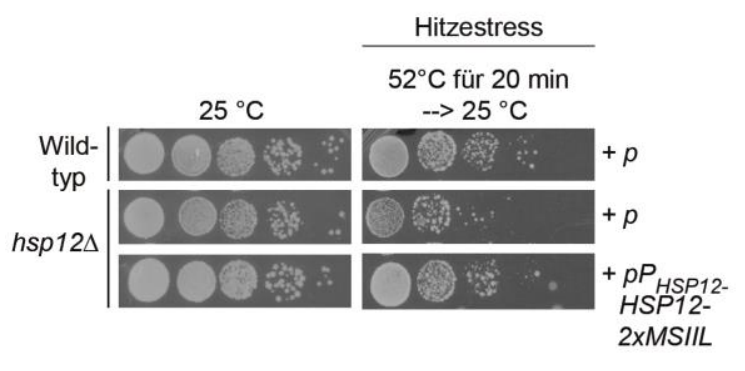

c

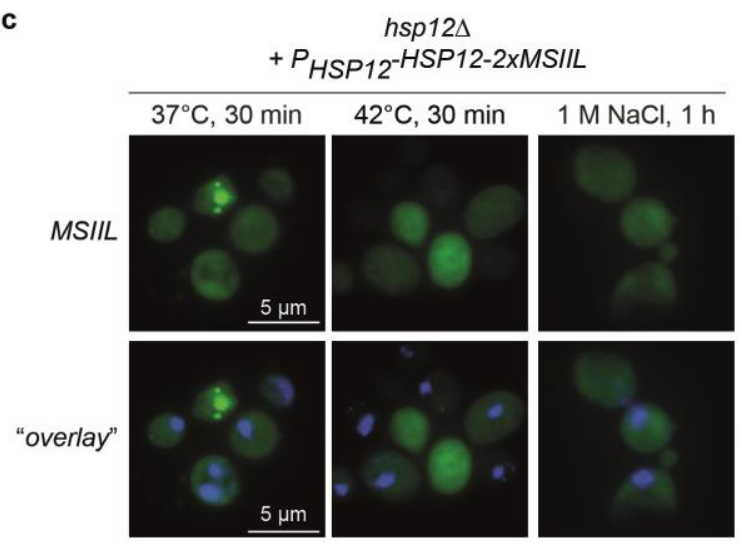

b
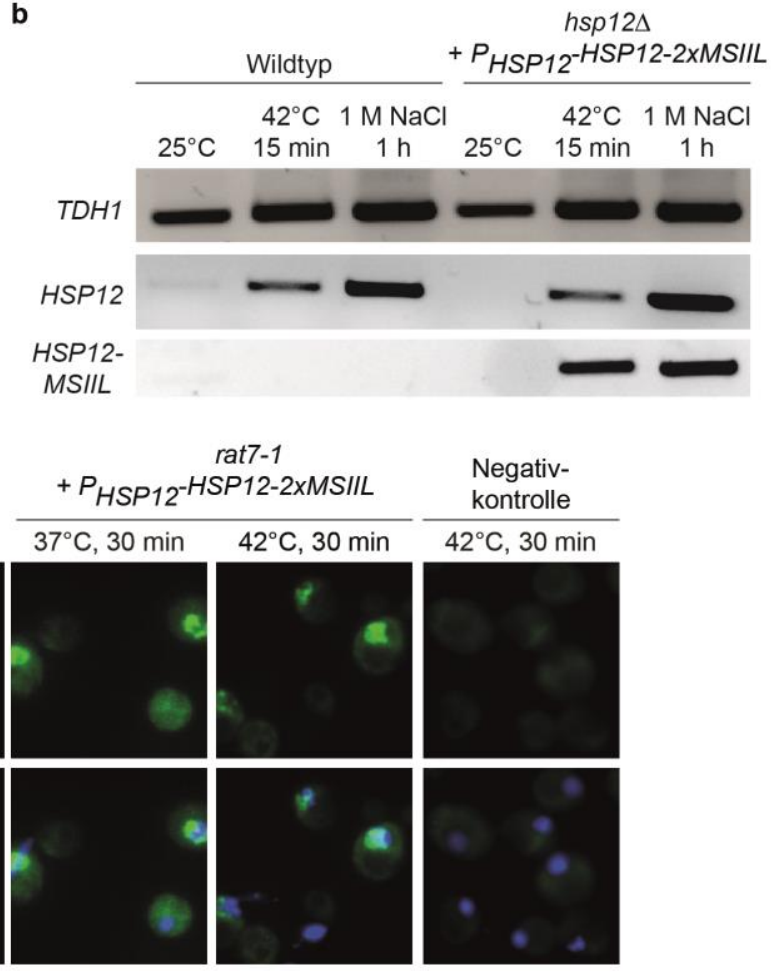

Negativkontrolle $42^{\circ} \mathrm{C}, 30 \mathrm{~min}$

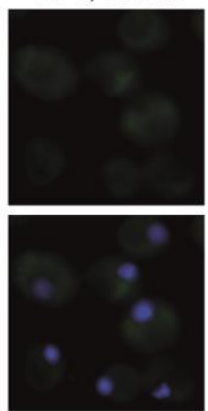

Abbildung 26: Die HSP12-2xMSIIL-mRNA wird synthetisiert und ist korrekt lokalisiert. A, Die Wachstumsanalyse zeigt den Wildtypstamm und den Deletionsstamm für HSP12 mit den integrierten Plasmiden in serieller Verdünnung auf Agar-Vollmedium-Platten mit angezeigtem Hitzestress. b, In der RT-PCR wird die Expression der HSP12-2xMSIIL-mRNA dargestellt. Nach Extraktion der Gesamt-RNA wurde sie in cDNA umgeschrieben und für die dargestellten Gene in einer PCR verwendet. Als Expressionsund Ladekontrolle wurde das Haushaltsgen TDH1 eingesetzt. C, FISH Experimente weisen die Lokalisation des HSP12-2xMSIIL-mRNA Konstruktes in hsp124 Zellen und in der mRNA-Exportmutante rat7-1 nach. Logarithmisch gewachsene Zellen wurden wie angezeigt behandelt, fixiert und mit einer Sonde gegen MSIIL hybridisiert. Die Negativkontrolle kennzeichnet Zellen ohne HSP12-2xMSIIL-mRNA Konstrukt. Im „overlay“ überlagert das FITC-Signal (grün) mit der Hoechst-gefärbten DNA (blau).

Die Wachstumsanalyse in Abbildung 26a zeigt das alle untersuchten Hefestämme nach dem Hitzeschock bei $52^{\circ} \mathrm{C}$ schlechter gewachsen sind, als die ungestressten Zellen bei $25^{\circ} \mathrm{C}$. Doch überleben in dem hsp12 $\triangle$ Stamm ohne funktionalem Hsp12 deutlich weniger Zellen nach Hitzeschock, als mit HSP12-2xMSIIL-mRNA Konstrukt. Im nächsten Experiment konnte die spezifische Expression der HSP12-2xMSIIL-mRNA mittels RT-PCR nachgewiesen werden (Abbildung 26b). Das Haushaltsgen TDH1 zeigt ein gleichbleibendes Signal auch während des Hitze- oder Salzstresses, im Gegensatz dazu findet eine spezifische Synthese der HSP12-mRNA bei Hitze- und Salzstress statt (Abbildung 26b). Die RT-PCR mit Oligonukleotiden gegen das komplette HSP12-2xMSIIL-Konstrukt zeigt, dass die mRNA spezifisch in den mit dem Konstrukt enthaltenen Zellen hergestellt wird und das es außerdem bei Hitze- und Salzstress induziert wird, da bei $25^{\circ} \mathrm{C}$ kein PCR-Produkt entstanden ist. In Abbildung 26c ist die Lokalisation der HSP12-2xMSIIL-mRNA in den 
hsp12A und rat7-1 Zellen zu erkennen. Eindeutig lässt sich die zytoplasmatische Verteilung des FITC-Signales der DIG-gekoppelten MSIIL-Sonde in den hsp124 Zellen nach dreißig minütigem Hitzestress erkennen. In der mRNA-Exportmutante rat7-1 kann insbesondere nach dem Hitzestress ein deutliches Signal im Zellkern detektiert werden, dass durch die Co-Lokalisation der Signale der MSIIL-Sonde mit der DNA im „overlay“ bestätigt wird. Im Gegensatz dazu zeigen die Wildtypzellen ohne Konstrukt erwartungsgemäß kein FITC-Signal.

\subsubsection{Analyse der interagierenden Proteine, die bei Hitzestress an die HSP12-2xMSIIL-mRNA binden}

Im nächsten Schritt wurden die Hefezellen mit einem zusätzlichen MS2CP-His-Prot-AKonstrukt transformiert. Das MS2-,,coating protein“ wurde mit einem His-Proteintag, einer TEV-Schnittstelle und einem ProteinA-Tag fusioniert, sodass eine Zwei-SchrittAufreinigung mittels zweifacher Präzipitation erfolgen konnte. Als Kontrolle wurden Zellen verwendet, die kein 2xMSIIL-Konstrukt (Wildtyp $+\mathrm{P}+\mathrm{P}_{\text {MET25-MS2CP-His-ProtA) }}$ exprimierten. Die Zellen wurden bis zur logarithmischen Phase kultiviert und entweder ungestresst oder nach einem Hitzestress $\left(42^{\circ} \mathrm{C}\right.$, für $\left.20 \mathrm{~min}\right)$ verwendet. Die lysierten Zellextrakte wurden für die 1. Aufreinigung mit der IgG-Sepharose inkubiert und das ProteinA-Tag präzipitiert. Durch das Schneiden mit der TEV-Protease wurde sichergestellt, dass das ProteinA-Tag an der IgG-Sepharose gebunden blieb und das aufzureinigende Konstrukt in den Überstand abgegeben wurde. Der Überstand wurde in einem 2. Aufreinigungsschritt mit einer Nickel-gekoppelten Agarose inkubiert, zur Präzipitation des His-Fusionstags. $20 \%$ der finalen Proben wurden weiterhin für eine Silbergelfärbung verwendet (Abbildung 27). Die restliche Probe wurde erneut durch eine SDS-PAGE kurz aufgetrennt und die Proteinbanden ausgeschnitten und mit Trypsin verdaut. Die aufgereinigten Peptidproben wurden massenspektroskopisch untersucht (von Dr. O. Valerius aus der Arbeitsgruppe von Prof. Dr. G. Braus durchgeführt) und in Tabelle 15 aufgelistet. 


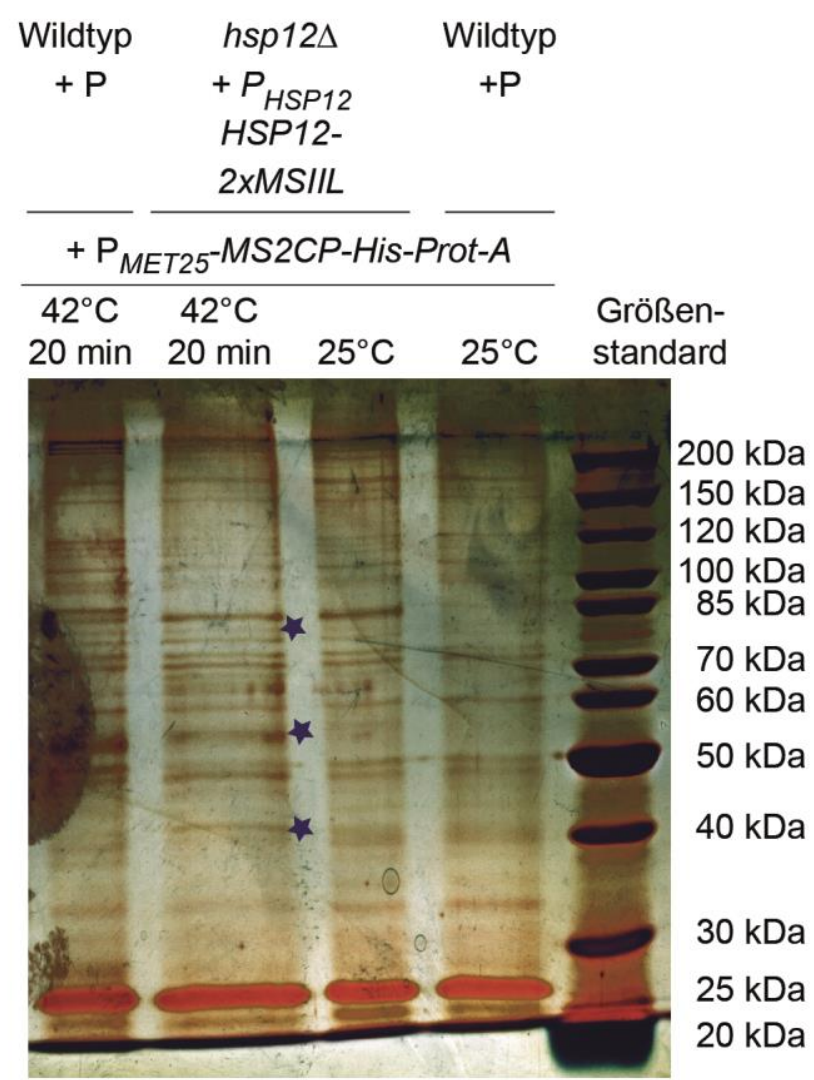

Abbildung 27: Proteine, die mit der HSP12-2xMSIIL-mRNA interagieren. Logarithmische Wildtyp- oder hsp 12A Zellen, die neben dem HSP12-2xMSIIL-Konstrukt oder einem Leervektor (+P), das MS2CP-His-ProtA Konstrukt beinhalteten, wurden entweder bei $25^{\circ} \mathrm{C}$ oder nach einem Hitzestress $\left(42^{\circ} \mathrm{C}\right.$ für 20 min) geerntet. Die gebundene mRNA wurde durch den MS2CP-His-ProtA-Fusiontag zweifach präzipitiert und $20 \%$ des Präzipitates wurde nach einer SDS-PAGE im dargestellten Silbergel visualisiert. Als Negativkontrolle dienten Wildtypzellen, die kein 2xMSIIL-Konstrukt beinhalteten. Die Sterne markieren zusätzliche Proteinbanden.

Das dargestellte Silbergel (Abbildung 27) zeigt die Probenspuren mit unterschiedlich aufgetrennten Proteinmuster. Es wurden viele Proteine identifiziert, die unspezifisch an die

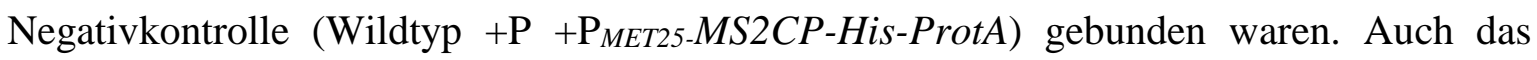
HSP12-2x-MSIIL-Konstrukt ohne Stress $\left(25^{\circ} \mathrm{C}\right)$ zeigt viele co-präzipitierte Proteinbanden. Doch nach Hitzestress $\left(42^{\circ} \mathrm{C}, 20 \mathrm{~min}\right)$ ließen sich in der Probe deutlich Proteinbanden identifizieren, die in allen anderen Proben nicht nachgewiesen wurden. Diese zusätzlichen Proteine sind in Abbildung 27 mit einem Stern gekennzeichnet und wurden massenspektroskopisch analysiert.

Die in Abbildung 27 identifizierten Proteinbanden wurden mittels MS-Analyse untersucht, im Anschluss mit der MaxQuant-Datenanalyse ausgewertet und mit dem Programm Perseus (von der TU München) bearbeitet. Mit Hilfe des Programmes wurden unterschiedliche Proben miteinander verglichen und bestimmt welche Peptide wie oft in jeder Probe zu finden waren. 
Tabelle 15: Proteine, die mit der HSP12-2xMSIIL-mRNA unter Hitzestress interagieren

\begin{tabular}{|c|c|c|c|c|c|c|c|}
\hline \multicolumn{3}{|c|}{$\begin{array}{c}\text { Anzahl der } \\
\text { identifizierten Peptide }\end{array}$} & \multicolumn{3}{|c|}{$\begin{array}{c}\text { Sequenz- } \\
\text { abdeckung [\%] }\end{array}$} & \multirow[t]{2}{*}{$\begin{array}{l}\text { Gen- } \\
\text { name }\end{array}$} & \multirow[t]{2}{*}{$\begin{array}{c}\text { Kurz- } \\
\text { beschreibung }\end{array}$} \\
\hline $\begin{array}{l}\text { Hitze } \\
\text { stress }\end{array}$ & \begin{tabular}{|l|} 
Ohne \\
Stress \\
\end{tabular} & $\begin{array}{l}\text { Negativ- } \\
\text { kontr. }\end{array}$ & $\begin{array}{l}\text { Hitze } \\
\text { stress }\end{array}$ & $\begin{array}{l}\text { Ohne } \\
\text { Stress } \\
\end{array}$ & $\begin{array}{c}\text { Negativ- } \\
\text { kontr. }\end{array}$ & & \\
\hline 13 & 0 & 0 & 20,9 & 0 & 0 & $U P F 1$ & $\begin{array}{l}\text { ATP-abhängige RNA-Helikase } \\
\text { und wichtig für den NMD- } \\
\text { Signalweg }\end{array}$ \\
\hline 9 & 5 & 1 & 28,6 & 13,2 & 2,2 & $Y D J 1$ & $\begin{array}{l}\text { Mitochondriales Protein } \\
\text { Importprotein und HSP40 Co- } \\
\text { Chaperon }\end{array}$ \\
\hline 7 & 6 & 0 & 32,7 & 25,3 & 0 & $R P P O$ & $\begin{array}{l}\text { Ribosomales Protein des 60S- } \\
\text { Partikels }\end{array}$ \\
\hline 7 & 1 & 0 & 26,1 & 6 & 0 & ZUOI & $\begin{array}{l}\text { Ribosomen-assoziiertes } \\
\text { Chaperon }\end{array}$ \\
\hline 6 & 3 & 2 & 12,3 & 6,6 & 4,2 & SSA3 & $\begin{array}{l}\text { Untereinheit des } \\
\text { Hitzeschockproteins } 70\end{array}$ \\
\hline 5 & 0 & 0 & 43,5 & 0 & 0 & $H S P 26$ & $\begin{array}{l}\text { Chaperonaktivität und RNA- } \\
\text { Bindeprotein }\end{array}$ \\
\hline 4 & 2 & 0 & 13,9 & 8,1 & 0 & $T U B 1$ & Alpha-Tubulin \\
\hline 4 & 5 & 0 & 16,4 & 19,5 & 0 & LYS9 & Saccharopin-Dehydrogenase \\
\hline 4 & 6 & 2 & 22,9 & 22,6 & 8,7 & $\mathrm{TDH} 2$ & $\begin{array}{l}\text { Glyceraldehyde-3-phosphate- } \\
\text { Dehydrogenase } 2\end{array}$ \\
\hline 4 & 4 & 0 & 20,1 & 13 & 0 & ENO1/2 & $\begin{array}{l}\text { Enolase 1/2, Phosphopyruvat- } \\
\text { Hydratase }\end{array}$ \\
\hline 3 & 6 & 0 & 10,5 & 19,4 & 0 & $T R P 3$ & $\begin{array}{l}\text { Indol-3-Glyzerol- } \\
\text { Phosphatsyntethase }\end{array}$ \\
\hline 3 & 6 & 0 & 4,2 & 6,5 & 0 & ARO1 & $\begin{array}{l}\text { Shikimatkinase; Shikimate } \\
\text { Dehydrogenase }\end{array}$ \\
\hline 3 & 2 & 0 & 19,4 & 8,5 & 0 & $A S C 1$ & $\begin{array}{l}\text { Guanine- } \\
\text { Nukleotidbindeprotein- } \beta- \\
\text { Untereinheit; inhibiert } \\
\text { Translation }\end{array}$ \\
\hline 3 & 2 & 0 & 22,3 & 22,3 & 0 & RPS 20 & $\begin{array}{l}\text { Ribosomales Protein des } 40 \mathrm{~S}- \\
\text { Partikels }\end{array}$ \\
\hline 3 & 3 & 0 & 10,5 & 10,5 & 0 & FET3 & Eisentransport-Oxidoreduktase \\
\hline 3 & 3 & 1 & 20 & 21,5 & 6,5 & RPS8 & $\begin{array}{l}\text { Ribosomales Protein des 40S- } \\
\text { Partikels }\end{array}$ \\
\hline 3 & 0 & 0 & 14,6 & 0 & 0 & $Y R A 1$ & RNA-Bindeprotein \\
\hline 2 & 1 & 0 & 39,4 & 17,4 & 0 & HTAl/2 & Histon H2A.2; Histon H2A.1 \\
\hline 2 & 1 & 0 & 3,3 & 1,8 & 0 & $S C P 160$ & RNA-Bindeprotein \\
\hline 2 & 0 & 0 & 3,1 & 0 & 0 & ILSI & $\begin{array}{l}\text { Isoleucin-tRNA-Ligase, } \\
\text { zytoplasmatisch }\end{array}$ \\
\hline 2 & 1 & 0 & 12,2 & 5,4 & 0 & $P D X 1$ & $\begin{array}{l}\text { Pyruvatdehydrogenase- } \\
\text { Komplex, mitochondrial }\end{array}$ \\
\hline 2 & 0 & 0 & 2,7 & 0 & 0 & $X R N 1$ & $5^{6}-3^{6}$-Exoribonuclease 1 \\
\hline 2 & 2 & 1 & 15,4 & 15,4 & 5,9 & RPS2 & $\begin{array}{l}\text { Ribosomales Protein des 40S- } \\
\text { Partikels }\end{array}$ \\
\hline 2 & 1 & 0 & 32,4 & 7,7 & 0 & RPS15 & $\begin{array}{l}\text { Ribosomales Protein des 40S- } \\
\text { Partikels }\end{array}$ \\
\hline 2 & 0 & 0 & 11,3 & 0 & 0 & LYS12 & $\begin{array}{l}\text { Homoisocitratedehydrogenase, } \\
\text { mitochondrial }\end{array}$ \\
\hline
\end{tabular}




\begin{tabular}{|c|c|c|c|c|c|c|l|}
\hline 2 & 1 & 0 & 6,9 & 1,6 & 0 & GUS1 & $\begin{array}{l}\text { Glutamate-tRNA-Ligase, } \\
\text { zytoplasmatisch }\end{array}$ \\
\hline 2 & 0 & 0 & 8,3 & 0 & 0 & PIL1 & $\begin{array}{l}\text { Eisosomen-Kernkomponente; } \\
\text { Deletion des Genes aktiviert } \\
\text { den Pkc1-Stress-Resistenz- } \\
\text { Signalweg }\end{array}$ \\
\hline 2 & 2 & 1 & 9,5 & 13,7 & 5,3 & RPS7B & $\begin{array}{l}\text { Ribosomales Protein des 40S- } \\
\text { Partikels }\end{array}$ \\
\hline 2 & 2 & 0 & 7,9 & 7,9 & 0 & CIS3 & Zellwandmannoseprotein \\
\hline 2 & 5 & 0 & 16,7 & 34,9 & 0 & RPSO & $\begin{array}{l}\text { Ribosomales Protein des 40S- } \\
\text { Partikels }\end{array}$ \\
\hline
\end{tabular}

In Tabelle 15 sind Proteine aufgelistet, die durch die MS-Analyse identifiziert wurden. Gezeigt sind alle Proteine, die 2 oder mehr Peptide in der Probe mit dem HSP12-2xMSIILKonstrukt nach dem Hitzestress beinhalteten. Zusätzlich wurde prozentual die Sequenzabdeckung der identifizierten Proteine dargestellt.

Das Protein Upf1 wurde mit 13 Peptiden, laut Perseus Programm, als Protein mit den meisten Peptiden identifiziert. Upf1 ist eine ATP-abhängige RNA-Helikase, die am „nonsens mediated mRNA decay“ (NMD) beteiligt ist. Dieser Kontrollmechanismus erkennt, während der Translation, vorzeitige Stoppcodons in den mRNAs und verhindert deren Expression als verkürzte Proteine. Zusätzlich konnte gezeigt werden, dass Upf1 reguläre aber auch falsche mRNAs gezielt in PBs lokalisiert (Sheth und Parker, 2006). Da es sich bei dem HSP12-2xMSIIL-Konstrukt um eine artifizielle mRNA handelt, könnte Upf1 das Konstrukt bei Hitzestress binden und gemeinsam in PBs lokalisieren (Sheth und Parker, 2006). Innerhalb der PBs wird dann entschieden, ob die HSP12-2x-MSIIL-mRNA abgebaut wird oder in die Translation eingebracht wird (Buchan und Parker, 2009). In weiteren Experimenten müsste die gemeinsame Co-Lokalisation gezeigt werden.

Interessanterweise konnte hier ebenfalls Hsp26 als HSP12-2x-MSIIL-interagierendes Protein identifiziert werden. Da dieses Protein bereits bei der MS-Analyse von Mex67-GFP festgestellt wurde und es als RNA-Bindeprotein bereits veröffentlicht wurde (Tsvetanova et $a l ., 2010)$, ist es ein interessanter Kandidat für den Stress-spezifischen Transport von Hitzestress-mRNAs.

Außerdem wurde in der Tabelle 15 auch Yra1 als Interaktionspartner von der HSP12-MSIIL-mRNA identifiziert. Unter normalen Wachstumsbedingungen ist bekannt, dass Yra1 an die mRNA bindet und so den mRNA-Exportrezeptor Mex67-Mtr2 auf die mRNA lädt (Strasser und Hurt, 2000). Dennoch dissoziiert dieses Protein am NPC und pendelt nicht mit den export-kompetenten mRNPs in das Zytoplasma. Es wurden drei Peptide des Proteins mit einer Sequenzabdeckung von 14,6 \% entdeckt. Obwohl gezeigt 
wurde, dass Yra1 während Hitzestress an die SSA4-mRNA bindet, weisen die Autoren dennoch in den unterschiedlichen Mutanten von YRAl die gleiche Proteinmenge an Ssa4-GFP vergleichend zum Wildtyp nach (Rollenhagen et al., 2007). Deshalb könnte es sich hier ebenfalls um eine unspezifische Bindung von Yra1 an die HSP12-MSIIL-mRNA handeln. Ein weiteres mRNA-Bindeprotein, welches in der MS-Analyse identifiziert wurde, ist Scp160 (Lang und Fridovich-Keil, 2000; Li et al., 2003). Es ist bereits bekannt, dass Scp160 spezifische mRNAs zur Knospenspitze der Tochterzelle transportiert und der Scp160-vermittelter RNA-Transport essentiell für den Chemotropismus und für die erfolgreiche Paarung der Hefezellen ist (Gelin-Licht et al., 2012; Guo et al., 2003). Ob Scp160 am Export der HSP12-MSIIL-mRNA in das Zytoplasma beteiligt ist, müsste in weiteren Untersuchungen geklärt werden.

\subsubsection{Mex67-Mtr2 bindet mRNAs in vitro}

In dieser Arbeit wurde gezeigt, dass die bisher bekannten Mex67-bindenden Adaptorproteine bei Stress von der poly $(\mathrm{A})^{+} \mathrm{RNA}$ dissoziieren und nicht am Export der Stress-spezifischen mRNAs beteiligt sind. Interaktionspartner von Mex67, die durch die MS-Analysen bei Stress identifiziert wurden, müssen in weiteren Experimenten näher untersucht werden und es ist unklar ob sie als Adaptoren für Mex67 und für die Hitzestress-mRNAs fungieren. Es besteht aber auch die Möglichkeit, dass Mex67 ohne Adaptorproteine an die Hitzestress-mRNA assoziiert vorliegt. Mex67 bindet direkt an die 5S rRNA (Yao et al., 2007). Außerdem wurde die Struktur von Mex67-Mtr2 untersucht und in vitro gezeigt, dass artifizielle RNA direkt mit einer ,loop“-Struktur innerhalb der NTF2ähnlichen Domäne von Mex67-Mtr2 interagieren kann (Aibara et al., 2015; Santos-Rosa et al., 1998). Um die Bindung von Mex67 an Stress-spezifische mRNAs zu untersuchen, wurde eine in vitro RNA-Bindestudie durchgeführt, wofür rekombinantes Mex67-GST und His6-Mtr2 in E. coli co-exprimiert und anschließend aufgereinigt wurden. Als Positivkontrolle wurde das RNA-Bindeprotein GST-Npl3 und als Negativkontrolle GST mit His6-Mtr2 rekombinant exprimiert. Die aufgeschlossenen Proteinlysate wurden mit der GSH-Sepharose und $50 \mu \mathrm{g}$ aufgereinigter Hefe-RNA für $1 \mathrm{~h}$ bei $4^{\circ} \mathrm{C}$ inkubiert. Danach wurde die Matrix gewaschen und aufgeteilt, dabei diente ein Zehntel der Matrix als Kontrolle und wurde auf ein SDS-Polyacrylamidgel aufgetragen und durch Western-Blot Analysen mit spezifischen Antikörpern gegen GST und HIS analysiert. In Abbildung 28a ist Mex67-GST im Eluat mittels Anti-GST gezeigt. Zusätzlich wird das co-präzipitierte His6-Mtr2 detektiert, was zeigt, dass Mex67 und Mtr2 in vitro interagieren und vermutlich 
funktional sind. Von den restlichen $90 \%$ der Matrix wurde die RNA extrahiert und aufgereinigt. Die präzipitierte RNA wurde mit Hilfe der Reversen Transkriptase in cDNA umgeschrieben und verschiedene Transkripte wurden mittels qRT-PCR detektiert. Als Kontrolle diente die 5S rRNA. In Abbildung 28b ist die Bindung von Mex67 an reguläre und Stress-spezifische Transkripte gezeigt.
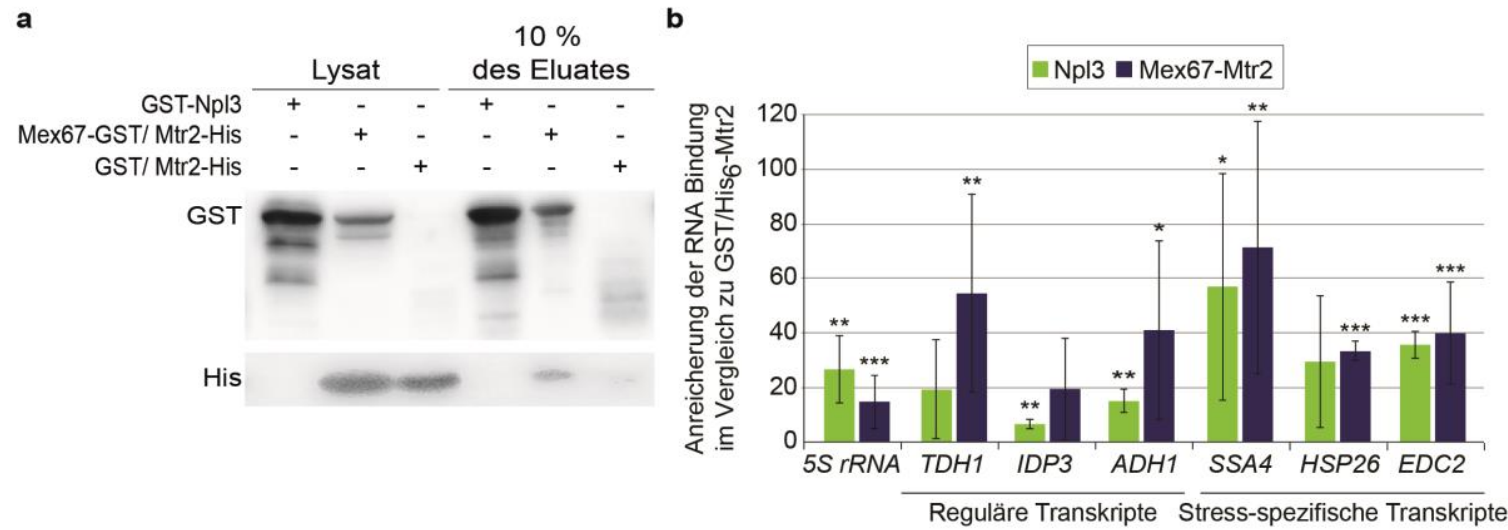

Abbildung 28: Mex67-Mtr2 kann in vitro mRNAs binden. GST-Mex67 und His 6 -Mtr2 wurden in E. coli BL21 Zellen co-exprimiert, an GSH-Sepharose gekoppelt und mit $50 \mu \mathrm{g}$ Gesamt-Hefe-RNA inkubiert. Zusätzlich diente GST-Npl3 als Positivkontrolle sowie GST und His 6 -Mtr2 als Negativkontrolle. A, Ein Zehntel der GSH-Sepharose wurde als Kontrolle mittels SDS-PAGE und Western-Blot Analyse mit Antikörpern gegen GST und HIS untersucht. B, Durch qRT-PCRs wurde die in vitro Bindung der gezeigten mRNAs an Npl3 und Mex67 nachgewiesen. Dazu wurde die Anreicherung der RNAs im Vergleich zur Negativkontrolle GST/His6-Mtr2 berechnet. Die Fehlerbalken repräsentieren die Standardabweichung und die angezeigten Signifikanzen (p-Werte) wurden mittels ungepaartem T-Test (Typ 3) berechnet. *** $=\mathrm{p}<0.001$, $* *=\mathrm{p}<0.01, *=\mathrm{p}<0,05$

Die Bindung der RNA an die rekombinant exprimierten Mex67-Mtr2- und Npl3-Proteine ist in Abbildung 28b dargestellt. Im Vergleich zur Negativkontrolle GST/His6-Mtr2 wird eine bis zu 20-fache Anreicherung der 5S rRNA an GST-Npl3 und Mex67-GST/His6-Mtr2 berechnet. Im Vergleich zur 5S rRNA sind die regulären und Stress-spezifischen Transkripte sogar stärker angereichert. Darüber hinaus zeigt sich, das Mex67-GST/His6-Mtr2 an jede mRNA mit ähnlicher Affinität bindet. Der mRNA-Exportrezeptor unterscheidet somit nicht zwischen regulärem Transkript und Stress-spezifischem Transkript. Auch GST-Npl3 bindet die RNA in vitro unabhängig davon, ob es ein stress-spezifisches oder ein reguläres Transkript ist und auch die 5S rRNA wird unter diesen Bedingungen gebunden. Da GST-Npl3 in E. coli exprimiert wurde, konnten keine posttranslationalen Modifikationen die RNA-Bindungsaffinität des Proteins beeinflussen, wodurch das Protein an jede beliebige RNA bindet. Dabei weist es aber vergleichend zu Mex67-Mtr2 im Mittelwert (min. 3 Experimente) aus allen gebunden Genen eine geringere Bindung auf. Daraus ergibt sich zusammenfassend, dass Mex67-Mtr2 starke mRNA-Bindungsaffinitäten in vitro besitzt. 
Interessanterweise konnten in vivo RIP Experimente zeigen, dass eine deutlich erhöhte Bindung von Mex67 an Stress-mRNAs besteht, im Vergleich zu Npl3 (Zander et. al., in Revision). Um zu untersuchen, ob Stress-spezifische mRNAs an die gleiche Domäne wie die 5S rRNA bindet, wurde die in vitro RNA-Bindestudie mit verschiedenen Mutantionen von Mex67 wiederholt. Diese Mutationen wurden bereits in Yao et al. (2007) beschrieben und weisen einerseits eine Deletion der ,loop“-Struktur (His-Mtr2-mex67 1 loopK343E) auf oder sie besitzen einen Aminosäureaustausch von sämtlichen Lysin- und Arginin- zu AlaninResten in dieser ,loop“-Struktur (His-Mtr2-mex67-loopKR>AA) (Abbildung 4). Die mutierten Proteine und das wildtypische Mex67 wurden polycistronisch mit dem His-Mtr2 in E. coli Rossetta Zellen exprimiert und mittels Protino Ni-NTA-Säulen aufgereinigt. Anschließend wurden die Proteine mit $100 \mu \mathrm{g}$ Gesamt Hefe-RNA inkubiert und an Ni-NTAAgarose gekoppelt, gewaschen und wie folgt aufgeteilt: Ein Zehntel diente wiederum als Kontrolle der Präzipitation der Konstrukte (Abbildung 29a). Die restlichen 90 \% wurden zur RNA-Aufreinigung verwendet. Durch Phenol-Chloroform-Extraktion wurde die assoziierte RNA extrahiert und anschließend in cDNA umgeschrieben. Verschiedene Transkripte wurden dann mittels qRT-PCR wie bereits beschrieben analysiert. Auch hier wurden die Experimente mindestens dreimal voneinander unabhängig wiederholt und anschließend wurde die RNA-Bindung der „loop“-mutierten Proteine im Verlgeich zum Wildtypprotein dargstellt (Abbildung 29b).

a

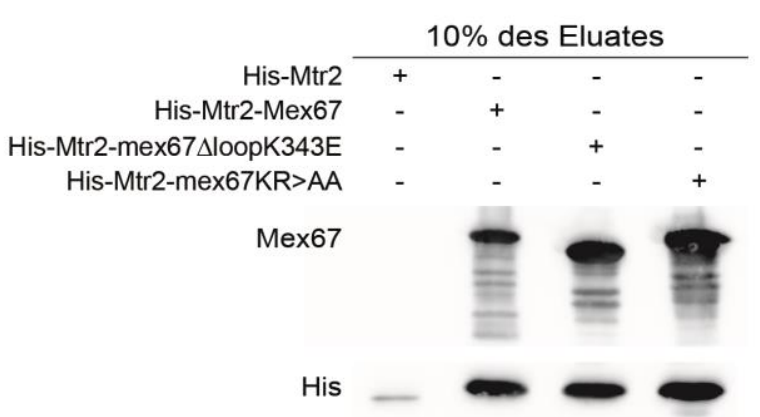

b

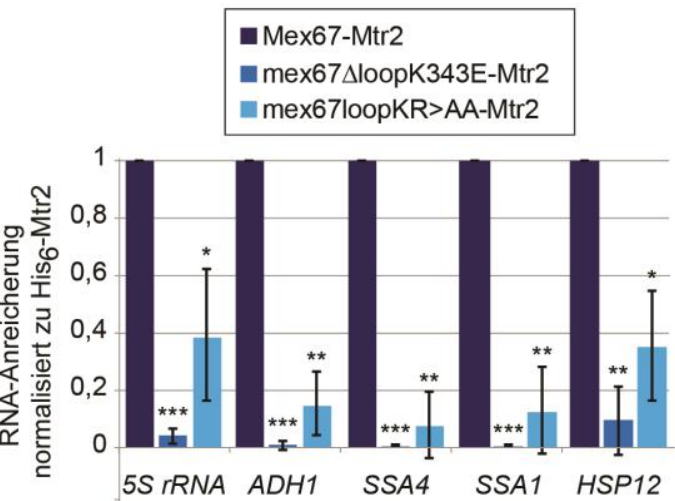

Abbildung 29: Mex67 benötigt seine, ,loop“-Domäne für die RNA-Bindung. A, Mex67 und dessen mutierte Versionen interagieren in vitro mit Mtr2 und wurden über eine Ni-NTA-Agarose aufgereinigt. B, In vitro RNABindestudien der ,loop"-mutierten Proteine sind im Vergleich zum Wildtypprotein dargestellt. Die Fehlerbalken zeigten die Standardabweichung an und die angezeigten Signifikanzen (p-Werte) wurden mittels ungepaarten t-Tests (Typ 3) berechnet. $* * *=p<0.001, * *=p<0.01, *=p<0,05$

Yao et al. (2007) zeigten in einem Band-Shift-Assay, dass die 5S rRNA deutlich schlechter von den Mex67-,,loop“-Struktur-Mutanten gebunden wird, als von dem Wildtypprotein. 
Dieses Ergebnis konnte hier reproduziert werden (Abbildung 29b). Darüber hinaus ist eine Abnahme der mRNA-Bindung in His-Mtr2-mex67DloopK343E und His-Mtr2-mex67loopKR>AA im Vergleich zum Wildtypprotein zu detektieren und bei ADH1, SSA4 und SSA1 ist sogar ein vollständiger Verlust der Bindung an His-Mtr2-mex67 1 loopK343E festzustellen. Wenn also die ,loop“-Struktur in Mex67 vollständig deletiert wird, kann der Rezeptor in vitro kaum noch RNA binden. Und bei einem Aminosäureaustausch in dieser „loop“-Domäne der positiv geladenen Aminosäuren Lysin und Arginin zu Alanin kommt es zu einer signifikanten Reduzierung der RNA-Bindung von Mex67-Mtr2. Auch bei dieser veränderten Form (His-Mtr2-mex67-loopKR>AA) von Mex67 werden die mRNATranskripte deutlich schlechter gebunden, als die 5S rRNA.

\subsubsection{Mex67-Mtr2 exportiert die Stress-spezifischen Transkripte direkt}

Die vorangegangenen in vitro RNA-Bindestudien zeigten, dass Mex67 mit Hilfe der „loop“-Struktur direkt an mRNA binden kann und dass diese Bindung durch Mutationen in der Domäne gestört ist. Daraus kann man einen Einfluss auf die in vivo Funktion von Mex67 vermuten. Um dies zu analysieren, wurden FISH Experimente mit den entsprechenden Mutanten und mit Sonden gegen die Stress-spezifischen mRNAs (SSA4 und HSP12) durchgeführt. Neben den Wildtypzellen als Kontrolle für den Export der Stress-spezifischen mRNAs wurden die mRNA-exportdefekten Mutanten mex67-5 und mtr2-21 verwendet. Bei diesen Temperatur-sensitiven Mutanten wurde bereits gezeigt, dass deutlich verringerter Export der Stress-spezifischen Transkripte SSA4 und HSP12 stattfindet (Abbildung 21). Zusätzlich wurden die Mex67-,,loop“-Struktur Mutanten mex67loopKR>AA und mex674409-435aa auf Exportdefekte von SSA4 hin untersucht. Eine weitere Mutante von Mtr2 (mtr2-33) wurde ebenfalls analysiert. Bei der semi-permissiven Temperatur von $37^{\circ} \mathrm{C}$ zeigt mtr2-33 Exportdefekte der prä-40S- und prä-60S-ribosomalen Untereinheiten, aber keine Defekte im Export der poly(A) ${ }^{+}$RNA (Baßler et al., 2001). Auch diese Mutante wurde auf Exportdefekte von SSA4 und HSP12 mittels FISH Experimenten analysiert. Dafür wurden Wildtypzellen und die beschriebenen Mutanten einem Hitzestress für 30 min bei $42^{\circ} \mathrm{C}$ ausgesetzt und anschließend fixiert (Abbildung 30; Abbildung 31). 


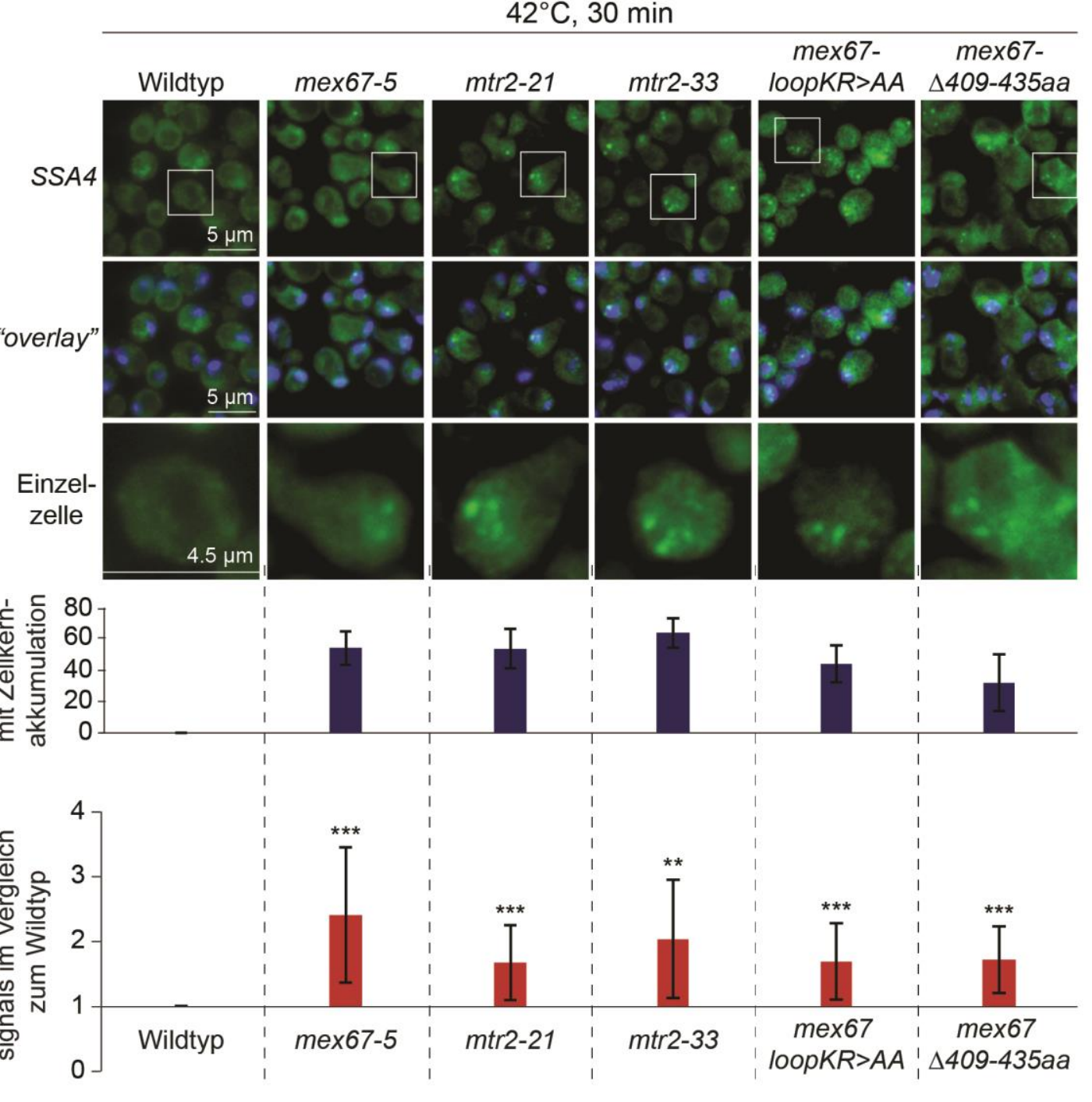

Abbildung 30: Die ,loop“-Domäne von Mex67-Mtr2 ist wichtig für den Export von der HitzestressmRNA SSA4. A, FISH Experimente wurden mit einer DIG-gekoppelte SSA4-Sonde in Wildtypzellen und in Zellen, die eine Mutation in MEX67 (mex67-5, mex67loopKR>AA und mex674409-435aa) oder in MTR2 (mtr2-21 und $m t r 2-33$ ) besitzen, durchgeführt. Alle Zellen wurden für 30 min einem Hitzestress bei $42^{\circ} \mathrm{C}$ ausgesetzt und anschließend fixiert. Der „overlay“ stellt eine Überlagerung des Signals von SSA4 (grün) mit dem Signal der DNA (blau) dar. B, Für das Diagramm wurden jeweils 100 Zellen gezählt und der prozentuale Anteil der Zellen mit Zellkernakkumulation dargestellt. c, Das Diagramm zeigt, die Anreicherung des Zellkernsignals im Vergleich zum gesamten Zellsignal und zum Wildtyp. Die Fehlerbalken stellten die Standardabweichungen dar und die angezeigten Signifikanzen ( $p$-Werte) wurden nach dem ungepaarten TTest (Typ 2) berechnet. $* * *=p<0.001, * *=p<0.01$

Während das Signal der SSA4-Sonde in Wildtypzellen eindeutig im Zytoplasma detektiert werden kann (Abbildung 30a), zeigt das Fluoreszenzsignal der SSA4-Sonde in den MEX67- und den MTR2-Mutanten ein signifikantes Zellkernsignal. Über $50 \%$ der Zellen von mex67-5 und mtr2-21 zeigen eine bis zu 2,5-fache Anreicherung des Zellkernsignals (Abbildung 30c). Auch die Mutante $m t r 2-33$ zeigt, dass $54 \%$ der gezählten Zellen eine zweifache Anreicherung des Zellkernsignals besitzen. 
Außerdem können signifikante Zellkernsignale in den „loop“-Mutanten mex67loopKR>AA und mex674409-435aa gemessen werden. Daher liegt die Schlussfolgerung nahe, dass Mex67 und Mtr2 nicht nur wichtig für den Export der Stress-spezifischen mRNA SSA4 unter Hitzestress sind, sondern auch dass die RNA-Bindung von der „loop“-Domäne abhängig ist.

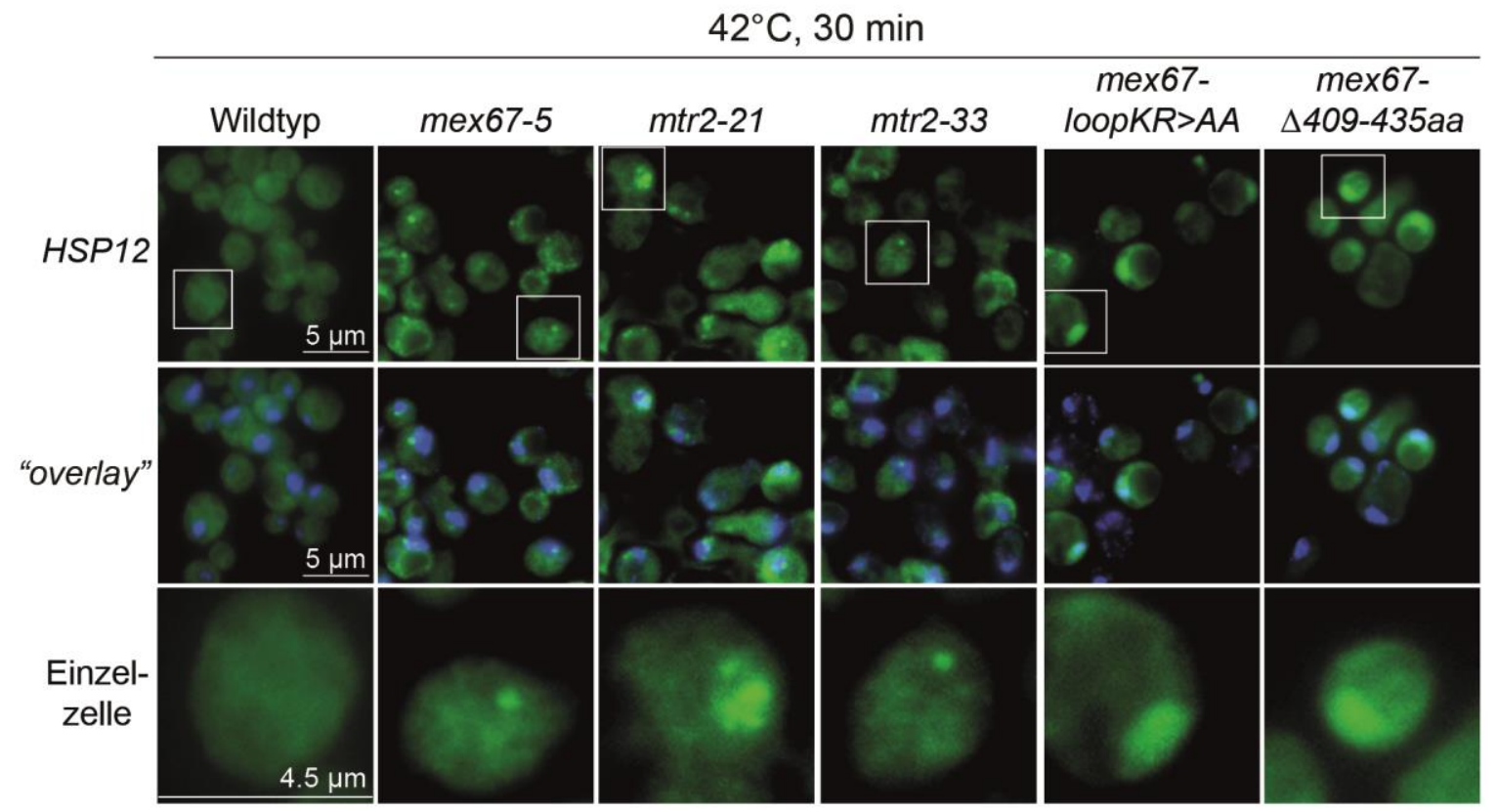

Abbildung 31: Mutanten von MEX67 und MTR2 zeigen Exportdefekte der HSP12-mRNA bei Hitzestress. FISH Experimente wurden durchgeführt mit einer DIG-gekoppelten HSP12-Sonde in Wildtypzellen und in Zellen, die eine Mutation in MEX67 oder in MTR2 besitzen. Logarithmische wachsende Zellen wurden nach Hitzestress für $30 \mathrm{~min}$ bei $42{ }^{\circ} \mathrm{C}$ sofort fixiert. Der ,overlay“ zeigt eine Überlagerung des grün-fluoreszierenden Signals von HSP12 und mit dem blaufluoreszierenden Signal, der mit Hoechst markierten DNA an.

Auch für die Stress-spezifische HSP12-mRNA sind eindeutige Exportdefekte in den Mutanten für MEX67 und MTR2 im Vergleich zu den Wildtypzellen sichtbar (Abbildung 31). In Wildtypzellen liegt HSP12 in der gesamten Zelle vor. Dagegen sind bei den Mutanten des Exportrezeptors deutliche Signale im Zellkern sichtbar. Diese Ergebnisse deuten darauf hin, dass Mtr2 und Mex67 mit seiner ,loop“-Struktur für den Export von Stress-spezifischen mRNAs benötigt werden. Zusammenfassend konnte gezeigt werden, dass Mex67 im Komplex mit Mtr2 für den Export von Stress-spezifischen mRNAs wichtig ist. Die pendelnden Mex67-bindenden Adaptorproteine Npl3, Nab2, Gbp2 und Hrb1 sind jedoch für den Transport der Stress-spezifischen mRNAs nicht notwendig. Während noch kein weiteres Protein eindeutig charakterisiert wurde, das als Mex67-bindendes Adaptorprotein bei Stress fungieren könnte, deuten die in vitro RNA-Bindestudien und die FISH Experimente daraufhin, dass Mex67-Mtr2 direkt mit der RNA interagieren und diese exportieren kann. 


\subsection{Mex67 ist bei Hitzestress mit dem Translationskomplex assoziiert}

Unter normalen Wachstumsbedingungen exportiert der heterodimere Exportrezeptor Mex67-Mtr2 die export-kompetenten mRNPs in das Zytoplasma (Segref et al., 1997) und wird am Kernporenkomplex durch Dbp5 von den mRNPs abgelöst (Lund und Guthrie, 2005). Darüber hinaus ist Mex67 am Export beider prä-ribosomalen Untereinheiten in das Zytoplasma beteiligt (Faza et al., 2012; Yao et al., 2007).

Bisherige Ergebnisse dieser Arbeit zeigen, dass Mex67-Mtr2 die Stress-spezifischen mRNAs durch direkte Bindung in das Zytoplasma transportieren könnte. Um die Fragestellung zu klären, ob Mex67 ebenfalls am NPC durch Dbp5 von den Stressspezifischen mRNAs dissoziiert, wurden Saccharose-DichtegradientenzentrifugationExperimente durchgeführt. Hierzu wurden GFP-Npl3 exprimierende Zellen verwendet und entweder Bedingungen ohne Stress bei $25^{\circ} \mathrm{C}$ oder einem Hitzestress bei $42^{\circ} \mathrm{C}$ für $20 \mathrm{~min}$ ausgesetzt. Zur Arretierung der translatierenden Ribosomen auf den mRNA-Molekülen erfolgte der Zellaufschluss in Gegenwart des Elongationsinhibitors Cycloheximid. Die Zellextrakte wurden auf lineare Saccharose-Dichtegradienten aufgetragen und durch Ultrazentrifugation wurden die Mono- und Polysomen von den freien ribosomalen Untereinheiten separiert. Anschließend wurden die Gradienten gleichmäßig fraktioniert und dabei wurde die Absorption bei $254 \mathrm{~nm}$ gemessen, wodurch ein rRNA-Profil erfasst wurde (Abbildung 32a). Während sich bei den Zellen, die bei $25^{\circ} \mathrm{C}$ kultiviert wurden ein Polysomprofil mit bis zu sechs Ribosomen zeigt, kann bei $42^{\circ} \mathrm{C}$ eine deutliche Reduktion der Polysomen und der Anzahl an mRNAs, die aktiv translatiert werden, erkannt werden. Dafür steigt bei $42^{\circ} \mathrm{C}$ der Monosomen-Peak, während die Polysomen geringer werden. Der Grund hierfür ist, dass während Stress die Translation der regulären mRNAs gestoppt wird und diese in SGs oder PBs ohne Polysomen gespeichert werden und nur wenige Stressspezifische Transkripte bevorzugt translatiert werden (Brengues und Parker, 2007).

Die gesammelten fraktionierten Proben wurden gelelektrophoretisch aufgetrennt und in Western-Blots analysiert. Die in Abbildung 32 dargestellten Ergebnisse wurden repräsentativ gezeigt und in mindestens drei voneinander unabhängigen Experimenten wiederholt. Zu Kontrollzwecken wurde ein Anti-Rps3 Antikörper und GFP-Npl3 verwendet. Bei Rps3 handelt es sich um ein Protein der kleinen ribosomalen Untereinheit, welche erwartungsgemäß vorwiegend in den 40S-, mono- und polysomalen Fraktionen detektiert werden konnte (Abbildung 32b). Bei Hitzestress $\left(42^{\circ} \mathrm{C}\right)$ lässt sich Rps3 hingegen vorwiegend in der monosomalen Fraktion nachweisen. Des Weiteren wurde GFP-Npl3 
verwendet. Das Protein bindet an die translatierenden mRNAs (Windgassen et al., 2004).

Bei Stress wird Npl3 vorwiegend mit den regulären mRNAs in SGs und PBs gespeichert (Abbildung 17; Mitchell et al., 2013).

a

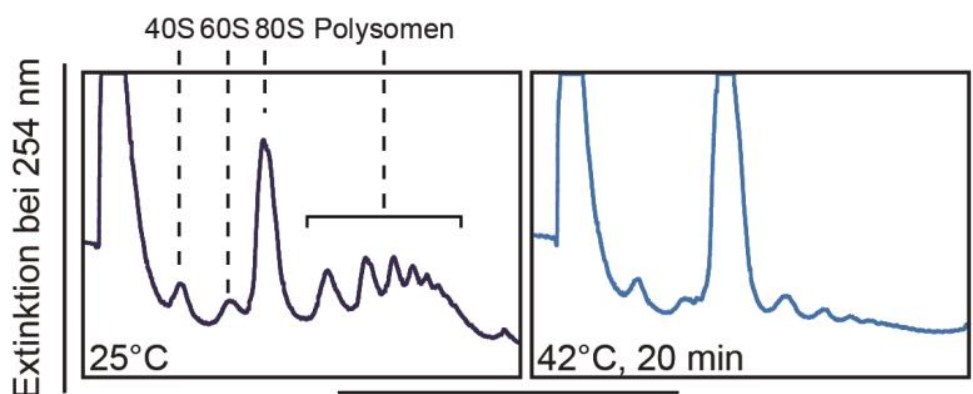

Zeit

b

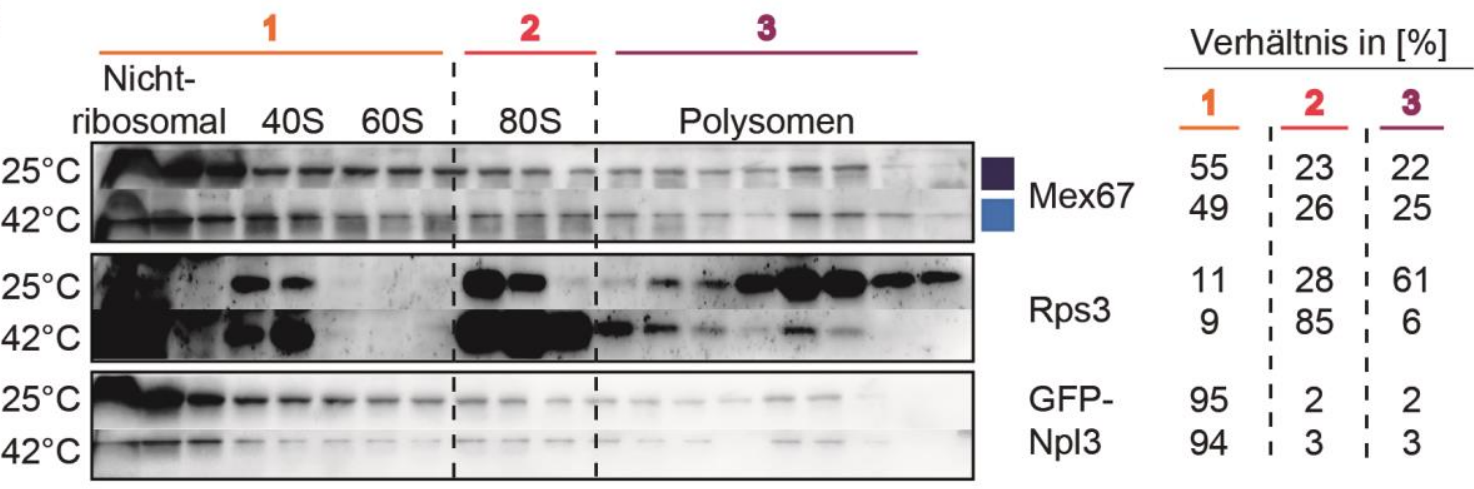

Abbildung 32: Mex67 bleibt bei Hitzestress an die aktiv translatierenden Polysomen gebunden. GFP-Np13 exprimierende Zellen wurden bei $25^{\circ} \mathrm{C}$ kultiviert und entweder ohne Stress $\left(25^{\circ} \mathrm{C}\right)$ geerntet oder bei $42^{\circ} \mathrm{C}$ für 20 min einem Hitzestress ausgesetzt, mit Cycloheximid behandelt und anschließend deren Extrakte auf lineare 10-50\% Saccharose-Dichtegradienten aufgetragen und zentrifugiert. a, Während der nachfolgenden Fraktionierung konnte die Verteilung der ribosomalen RNA durch kontinuierliche Messung der Absorption bei $254 \mathrm{~nm}$ verfolgt werden. b, Die Proteine aus den Fraktionen wurden präzipitiert, mit einer SDSPAGE aufgetrennt und in einer Western-Blot Analyse mit Anti-Rps3-, Anti-GFP- und Anti-Mex67Antikörpern detektiert. Die Immunblots wurden in 3 Kategorien, eingeteilt und das Verhältnis der Proteine in den entsprechenden Kategorien wurde mit dem gesamten Proteinlevel verglichen und rechts dargestellt.

Mex67 verteilt sich bei $25^{\circ} \mathrm{C}$ über das gesamte Polysomprofil (Abbildung 32b). Auch bei Hitzestress wird Mex67 in den noch bestehenden Polysomen detektiert, zusätzlich lässt sich Mex67 aber auch in den 80S-Monosomen nachweisen. Da Mex67 nicht nur mRNAs, sondern auch die ribosomalen Untereinheiten vom Zellkern in das Zytoplasma transportiert und von diesen im Gegensatz zur mRNA nicht durch Dbp5 nach dem Transport abgelöst wird, ist Mex67 unter normalen Wachstumsbedingungen in der polysomalen Fraktion zu detektieren (Neumann et al., 2016). 
Mex67 assoziiert auch bei Hitzestress an die Polysomen (Abbildung 32b), dabei stellt sich die Frage, ob Mex67 ebenfalls über die ribosomalen Untereinheiten an den Translationskomplex gebunden wird, oder ob die Assoziation von Mex67 an die Polysomen durch die Stress-spezifischen mRNAs verursacht wird. Aus diesem Grund wurden Saccharose-Dichtegradienten wiederholt und diesmal erfolgte eine Puromycinbehandlung, bevor das Zellextrakt auf den Gradienten aufgetragen wurde. Puromycin fungiert als Aminoacyl-tRNA-Analogon wirkendes Antibiotikum und kann so die selektive Zerstörung der Polysomen veranlassen. Die wachsenden Peptidketten werden im Verlauf der GTP-abhängigen Translationselongation auf Puromycin übertragen, woraufhin es zu einem vorzeitigen Kettenabbruch und einer Dissoziation der Ribosomen von den mRNAMolekülen kommt (Blobel und Sabatini, 1971).

GFP-Npl3 exprimierende Zellen wurden daher ohne Zusatz des Elongationsinhibitors Cycloheximid entweder mit oder ohne Hitzestressbehandlung bei $42^{\circ} \mathrm{C}$ für 20 min lysiert. Die Zellextrakte wurden mit Puromycin und GTP versetzt und für 15 min bei $25^{\circ} \mathrm{C}$ (ohne Stress) oder $42^{\circ} \mathrm{C}$ (Hitzestress) inkubiert. Im Anschluss wurden die Extrakte auf SaccharoseDichtegradienten aufgetragen, zentrifugiert, fraktioniert und in Western Blots analysiert (Abbildung 33). Auch hier wurden die Experimente mindestens dreimal unabhängig voneinander wiederholt und in Abbildung 34 zusammengefassend ausgewertet. Wie anhand der Profile und der Verschiebung des Rps3-Signals zu erkennen ist, resultierte der Zusatz von Puromycin und GTP in einem Rückgang der Polysomen bei gleichzeitiger Zunahme der mRNA-freien Mononomen bei $25^{\circ} \mathrm{C}$ und $42^{\circ} \mathrm{C}$ (Abbildung 33a). Die Zunahme der Mononomen ist auf eine Reassoziation der dissoziierten, funktionsfähigen ribosomalen Untereinheiten im Verlauf der Zentrifugation zurückzuführen, jedoch ohne mRNA gebunden zu haben (Blobel und Sabatini, 1971). Die Fraktionen sind im Western Blot in folgende Kategorien unterteilt: Den 1. Teil bilden die Nicht-ribosomale Fraktionen und die ribosomalen Untereinheiten, die Kategorie 2 beinhaltet die monosomale Fraktion (80S) und die 3. Kategorie zeigen die Komplexe, die nicht durch die Puromycinbehandlung zerstört wurden (Abbildung 33b). 
a

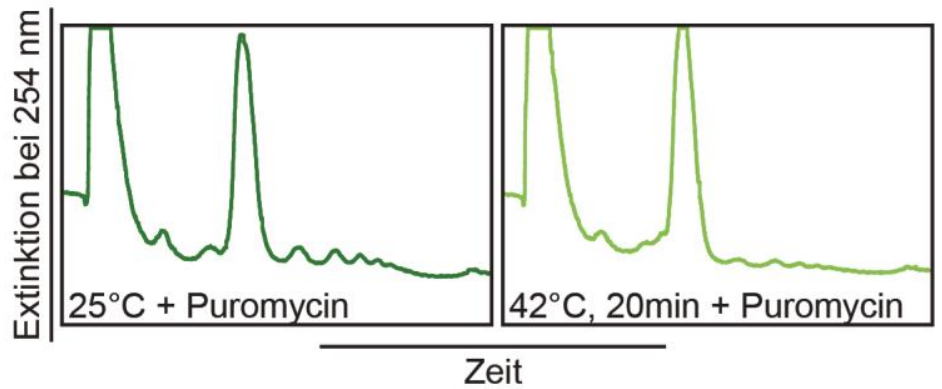

b

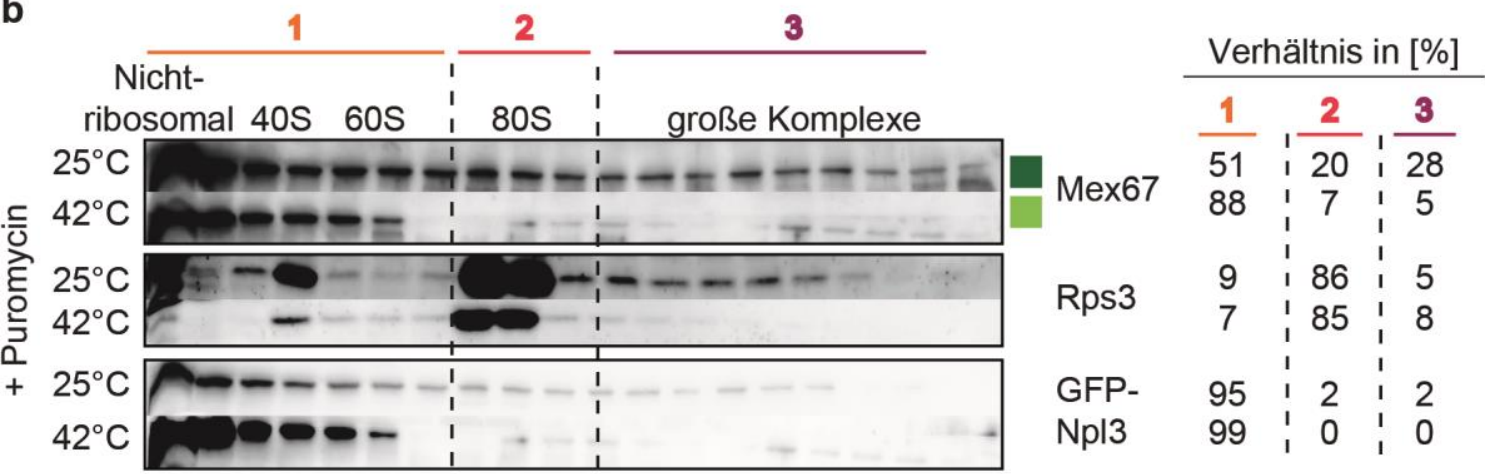

Abbildung 33: Durch die selektive Zerstörung der Polysomen ist Mex67 nach Hitzestress nicht mehr Ribosomen-gebunden. Zellextrakte mit GFP-Np13 wurden zur selektiven Zerstörung der Polysomen mit Puromycin und GTP versetzt und für 15 min bei $25{ }^{\circ} \mathrm{C}$ oder $42{ }^{\circ} \mathrm{C}$ inkubiert (+ Puromycin). A, Die Extrakte wurden auf lineare 10-50 \%ige Saccharose-Dichtegradienten aufgetragen, fraktioniert und das rRNA-Profil aufgezeichnet. B, Die in den Fraktionen enthaltenen Proteine wurden gefällt, gelelektrophoretisch aufgetrennt und in Western Blots mit Anti-Rps3-, Anti-GFP- und Anti-Mex67-Antikörpern analysiert. Auch hier wurden die Western Blots in die Kategorien 1-3 für weitere Analysen in Abbildung 34 unterteilt. Zudem wurde das Verhältnis der Proteine vergleichend zum gesamten Proteinlevel rechts angezeigt.

Die Puromycinbehandlung führte zur Zerstörung der Polysomen bei $25^{\circ} \mathrm{C}$ und bei $42^{\circ} \mathrm{C}$ (Abbildung 33a). Auch erkennt man bei beiden Temperaturen eine verstärkte RNA-freie Monosombildung, was die Proteinsignale von Rps 3 mit $86 \%$ und 85\% in Kategorie 2 bestätigen (Abbildung 33b). Während das Proteinsignal von Mex67 bei $25^{\circ} \mathrm{C}$ in der Kategorie 2 (80S-Fraktion) nicht geringer wird, sondern immer noch $20 \%$ des Proteins an die Monosomen gebunden bleiben, zeigt sich eine signifikante Reduktion des Mex67Signals nach dem Hitzestress (Abbildung 33b). Es findet eine Verschiebung des Mex67Signals in die Kategorie 1 mit $88 \%$ statt. In den Puromycin-behandelten Proben war bei Hitzestress parallel zu dem Rückgang der Polysomen eine signifikante Reduktion von Mex67 in den monosomalen und in der Fraktion mit den großen Komplexen zu beobachten (Abbildung 33b und Abbildung 34). 


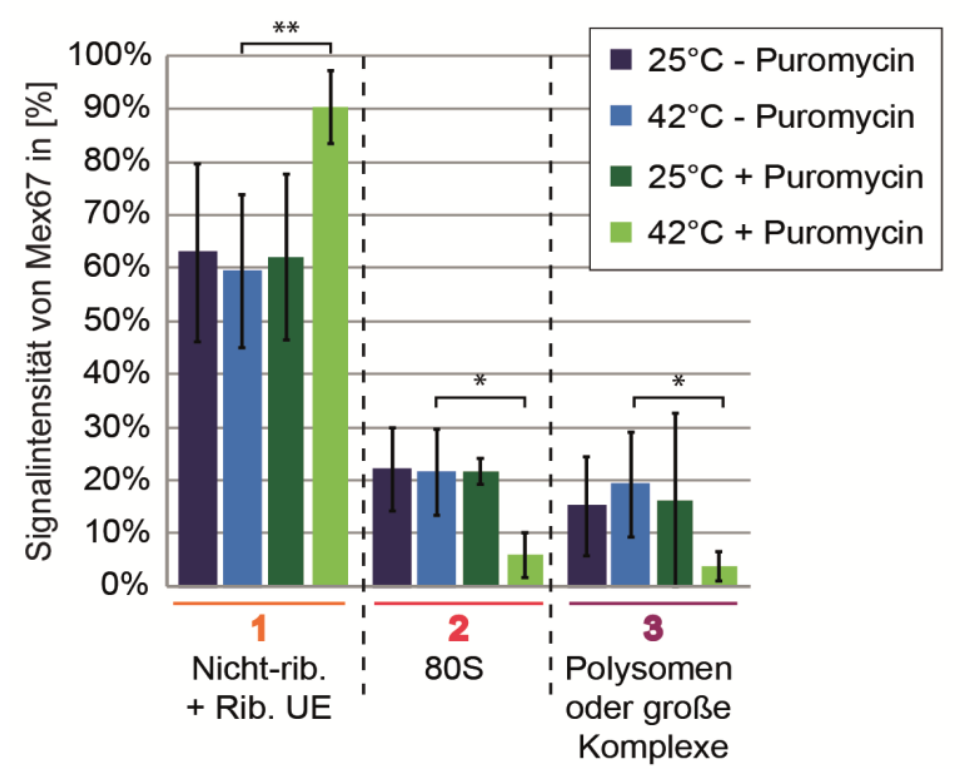

Abbildung 34: Bei Hitzestress bleibt Mex67 an die Stress-spezifischen Transkripte gebunden und ist daher in Polysomen zu detektieren. Das dargestellte Diagramm spiegelt die Signalintensitäten von Mex67 nach Saccharose-Dichtegradienten mit der Cycloheximid-Behandlungen bei $25^{\circ} \mathrm{C}$ und $42^{\circ} \mathrm{C}$ wider (Abbildung 32). Zusätzlich wurde eine Puromycin-induzierte Ribosomendissoziation durchgeführt (Abbildung 33). Mittels Bio-ID Programm (von Peqlab) wurden die Signalintensitäten der präzipitierten Proteine statistisch berechnet. Die Fehlerbalken repräsentieren die Standardabweichung und die angezeigten Signifikanzen (p-Werte) wurden mit dem ungepaarten T-Test (Typ 3) berechnet. $* *=p<0.01, *=p<0,05$

Wie in Abbildung 34 grafisch dargestellt ist, verteilt sich Mex67 unter Bedingungen ohne Stress $\left(25^{\circ} \mathrm{C}\right)$ im gesamten Saccharose-Dichtegradienten. Dabei liegt Mex67 wahrscheinlich größtenteils an die ribosomalen Untereinheiten gebunden vor (Neumann et al., 2016). Nach der Puromycinbehandlung bleibt Mex67 bei $25^{\circ} \mathrm{C}$ über die ribosomalen Untereinheiten gebunden und deshalb verändert sich die Bindung von Mex67 an die 80S-Monosomen nicht erheblich (Abbildung 34, Kategorie 2). Während eines Hitzestresses lässt sich Mex67, ebenso über den gesamten Saccharose-Dichtegradienten verteilt detektieren, wird aber durch die Puromycinbehandlung von den Monosomen abgelöst und es findet eine signifikante Reduktion des 80S-Monosomenssignals statt. Somit liegt Mex67 nach der Puromycinbehandlung und nach dem Hitzestress nicht mehr an die Monosomen gebunden vor. Dass deutet darauf hin, dass Mex67 nicht nur wie unter normalen Wachstumsbedingungen über die ribosomalen Untereinheiten an den Translationskomplex bindet, sondern direkt an Stress-spezifische mRNAs gebunden ist und auch während der Translation zumindest in der ersten Translationsrunde an diese assoziiert bleibt. 


\subsection{Die Qualität der regulären mRNAs wird vor dem Transport kontrolliert, während die Stress-spezifischen Transkripte unkontrolliert in das Zytoplasma exportiert werden}

Unter normalen Wachstumsbedingungen wird die poly $(\mathrm{A})^{+} \mathrm{RNA}$ an verschiedene Adaptorproteine gebunden, die wiederum mit dem heterodimeren mRNA-Exportrezeptor Mex67-Mtr2 interagieren und so die mRNAs in das Zytoplasma exportieren. Doch bei Stress dissoziieren die mRNA-Adaptoren Np13, Nab2, Gbp2 und Hrb1 im Zellkern von der poly $(\mathrm{A})^{+} \mathrm{RNA}$ und fungieren nicht als Exportfaktoren (Abbildung 21). Nun stellt sich die Frage warum die Adaptorproteine dennoch wichtig für den Transport von regulären Transkripten aus dem Zellkern in das Zytoplasma sind, wenn doch Mex67 direkt RNA binden kann (Abbildung 28). Für Gbp2 und Hrb1 konnte bereits eine Funktion in der mRNA-Qualitätskontrolle von gespleißten mRNAs gezeigt werden (Hackmann et al., 2014). Es wurde ein Modell vorgeschlagen, nachdem Gbp2 und Hrb1 beispielsweise Mtr4, die ATP-abhängige RNA-Helikase des TRAMP-Komplexes, an die ungespleißte prä-mRNAs rekrutieren. Somit wird die prä-mRNA auf Prozessierung und vollständiges Spleißen hin kontrolliert und ob das Intron korrekt entfernt wurde. Ist dies nicht der Fall, werden die entstandenen prä-mRNAs durch das nukleäre Exosom abgebaut. Sind die Transkripte jedoch korrekt und können exportiert werden, dissoziiert Mtr4 wieder und Mex67 bindet an die Adaptorproteine Gbp2 und Hrb1 (Hackmann et al., 2014).

Um zu untersuchen, ob die mRNA-Qualitätskontrolle auch während Stress aktiv ist, sollen FISH Experimente mit spezifischen Sonden gegen SSA4 und HSP12 durchgeführt werden. Dabei soll untersucht werden, ob falsche und nicht-prozessierte Stress-spezifische mRNAs bei Hitzestress im Zellkern akkumulieren. Dafür wurden Mutanten der mRNAQualitätskontrolle (mtr4-G677D) sowie eine nukleäre Exosommutante rrp64 verwendet. Neben den genannten Mutanten wurden Wildtypzellen und die temperatur-sensitiven exportdefekten Mutanten mex67-5 und mtr2-21 als Kontrolle verwendet. Eine Cy3gekoppelte Oligo $\mathrm{dT}_{(50)}$ Sonde diente als interne Kontrolle, um die Zellkernakkumulation von poly $(\mathrm{A})^{+} \mathrm{RNA}$ während Hitzestress zu zeigen (Abbildung 35). 

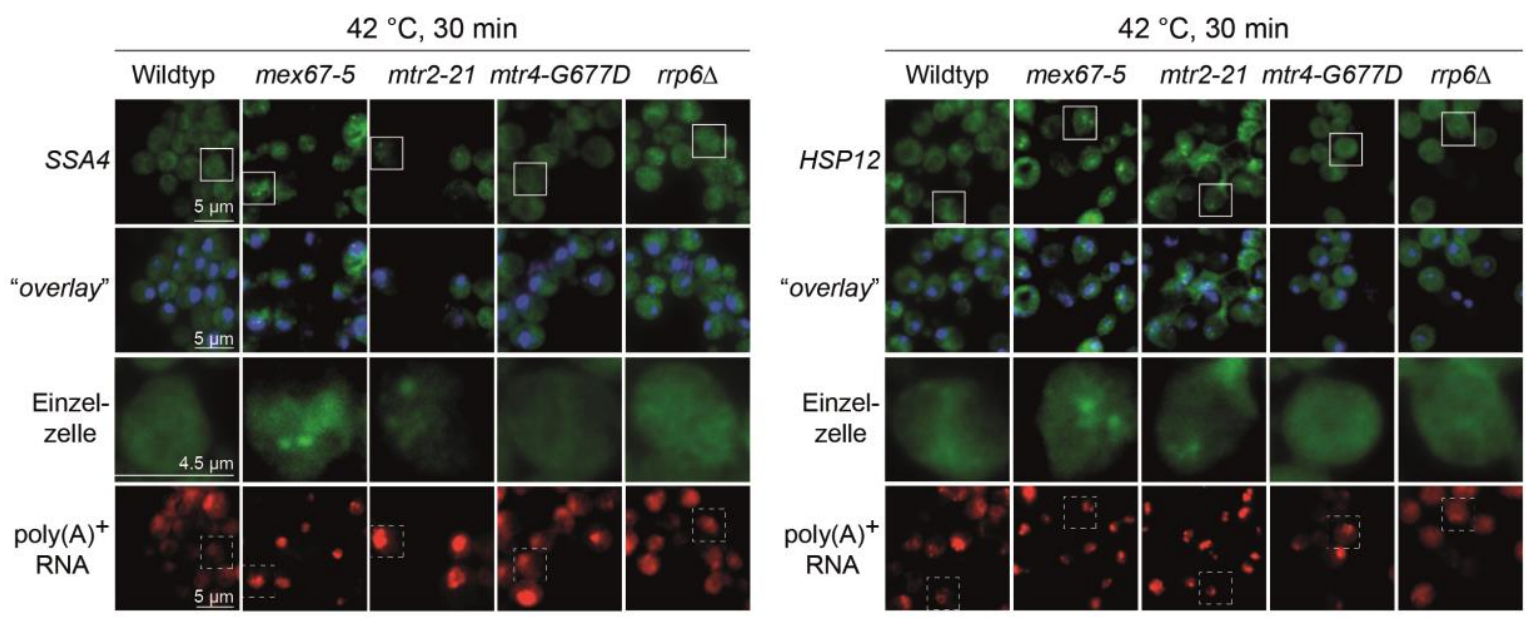

Abbildung 35: Der Export der SSA4-mRNA und der HSP12-mRNA ist in den Mutanten des TRAMPKomplexes oder des nukleären Exosoms nicht beeinträchtigt. In FISH Experimenten wurden Wildtypzellen, mex67-5, mtr2-21, mtr4-G677D und rrp64 Zellen nach Hitzestress bei $42^{\circ} \mathrm{C}$ für 30 min fixiert, und mit der DIG-markierten a, SSA4-mRNA oder b, HSP12-mRNA gegen eine FITC-Sonde (grün) und einer Cy3-gekoppelten Oligo-dT $\mathrm{T}_{(50)}$-Sonde (rot) hybridisiert. Im ,overlay“ ist das grün-fluoreszierende FITC-Signal mit dem blau-fluoreszierenden Hoechst Signal der DNA überlagert.

Wie in Abbildung 35 gezeigt wird, akkumuliert die poly(A) ${ }^{+}$RNA im Zellkern nach einem 30-minütigen Hitzestress in allen Hefestämmen. Die Stress-spezifischen mRNAs SSA4 und HSP12 zeigen in den exportdefekten Mutanten mex67-5 und mtr2-21 eine deutliche Akkumulation im Zellkern (Abbildung 35). Doch in den Mutanten $m t r 4-G 6777 D$ und rrp64 kann man keine Akkumulation der Stress-spezifischen mRNAs im Zellkern erkennen. Ähnlich wie im Wildtypstamm kann man ein deutliches Signal der untersuchten mRNAs im Zytoplasma detektieren. Das bedeutet, dass keine Stress-spezifischen mRNAs im Zellkern akkumulieren und vermutlich alle entstandenen Transkripte in das Zytoplasma transportiert werden. In Abbildung 35 wurde der Hitzestress für dreißig Minuten durchgeführt. Diese Zeit ist eventuell nicht ausreichend um eine sichtbare Akkumulation der falschen oder nichtprozessierten Stress-spezifischen Transkripte zu detektieren. Aus diesem Grund wurde das FISH Experiment für eine Stunde wiederholt und in Abbildung 36 dargestellt. 


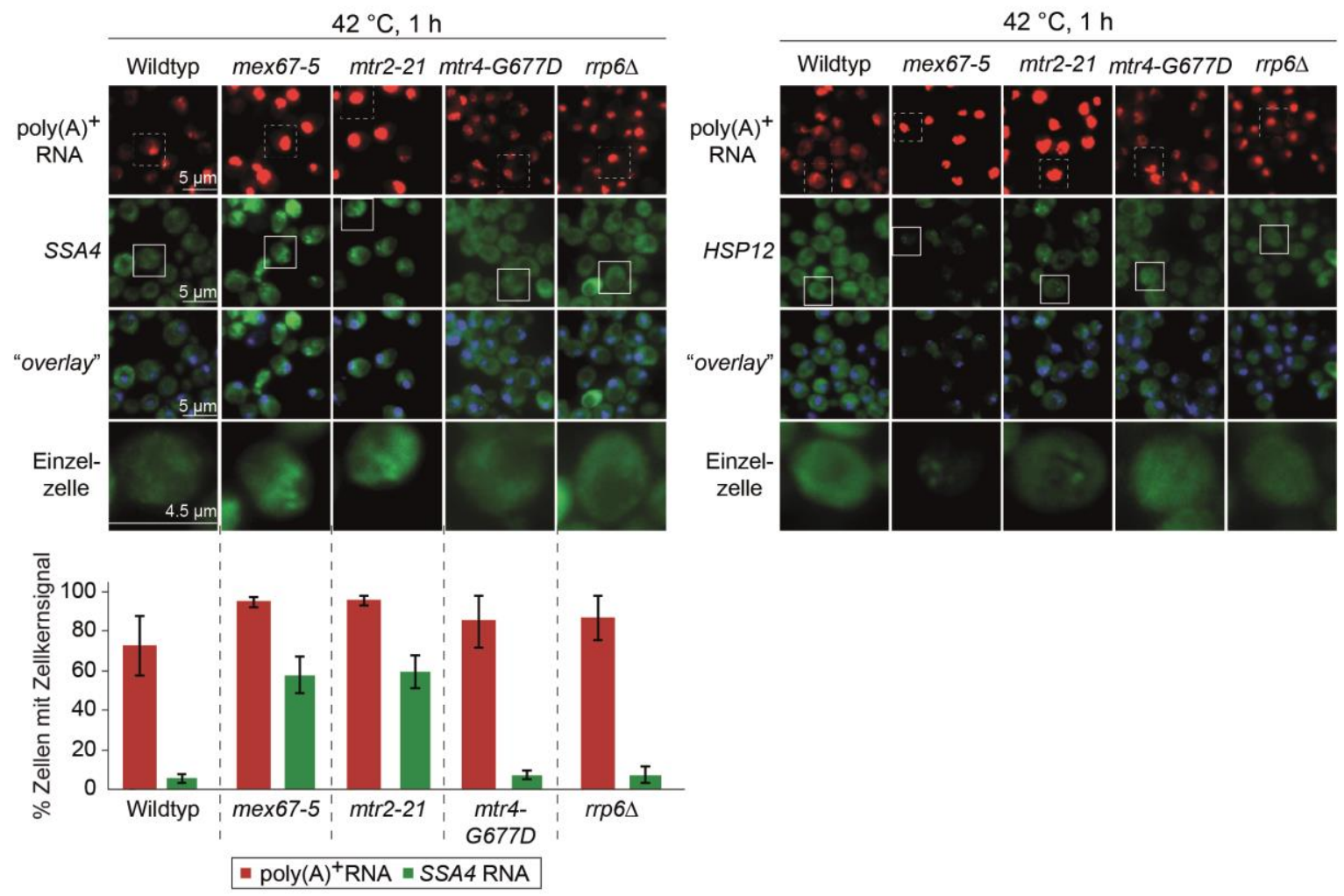

Abbildung 36: Die Stress-spezifischen Transkripte $S S A 4$ und HSP12 werden unabhängig von der Dauer des Hitzestresses und unabhängig von Mtr4 und Rrp6 ins Zytoplasma exportiert. FISH Experimente zeigen Wildtypzellen, die export-defekten Mutanten mex67-5 und mtr2-21 sowie mtr4-G677D und rrp64, die mit Cy3-gekoppelter Oligo $\mathrm{dT}_{(50)}$ Sonde (rot) und DIG-gekoppelter a, SSA4-mRNA oder b, HSP12-mRNA Sonde (grün) hybridisiert wurden. Die Zellen wurden für $1 \mathrm{~h}$ bei $42^{\circ} \mathrm{C}$ hitzegestresst. Der „,overlay“ zeigt die Überlagerung des FITC Signals mit dem Hoechst Signal (DNA). C, Das Diagramm stellt den prozentualen Anteil der Zellen mit einem Zellkernsignal der poly(A)+RNA (rot) und der SSA4 mRNA (grün) dar. Es wurden mindestens 100 Zellen pro Bedingung gezählt.

Auch nach einer Stunde Hitzestress zeigen die untersuchten Mutanten der mRNAQualitätskontrolle mtr4-G677D und die nukleären Exosommutante rrp64 keine Akkumulation der Stress-spezifischen Transkripte SSA4 und HSP12 im Zellkern (Abbildung 36). Im Vergleich dazu kann man wiederum ein eindeutiges Zellkernsignal für die poly $(\mathrm{A})^{+} \mathrm{RNA}$ in allen gezeigten Hefestämmen feststellen. Nach Quantifizierung des Zellkernsignals der SSA4-mRNA zeigen $50 \%$ bis $60 \%$ der Zellen in den Exportmutanten eine Anreicherung des Signals im Zellkern, während mtr4-G677D und rrp64 keine Anreicherung des FITC-Signals im Zellkern zeigen (Abbildung 36c). Das weist darauf hin, dass keine Akkumulation von falschen Transkripten im Zellkern nach Hitzestress stattfindet. Im Unterschied dazu findet unter normalen Wachstumsbedingungen während der Beladung der mRNA mit den Adaptorproteinen eine Überprüfung der reifenden mRNA statt. Bei Deletion der Adaptoren findet keine Akkumulation der mRNA statt, sondern vielmehr ein „Auslaufen“" von nicht-prozessierten RNAs in das Zytoplasma (Hackmann et al., 2014). 
Die Deletion des RRP6 Genes hat eine Akkumulation von falschen Transkripten im Zellkern zur Folge und es kommt dadurch zur poly $(\mathrm{A})^{+}$RNA Anreicherung im Zellkern. Doch die zusätzliche Deletion der mRNA Adaptoren NPL3, NAB2, GBP2 und HRB1 führt zu einer signifikanten Verringerung des poly $(\mathrm{A})^{+} \mathrm{RNA}$ Signals im Zellkern (Zander et. al., in Revision). Das weist darauf hin, dass mehr RNAs in das Zytoplasma entlassen werden, die normalerweise durch die Adaptoren im Zellkern festgehalten werden.

\subsection{Der Export der Stress-spezifischen mRNAs wird über den Promoter kontrolliert}

Wie wird sichergestellt, dass bei Stress die Stress-induzierten Transkripte exportiert werden und die regulären mRNAs nicht? Die vorangegangenen Experimente haben gezeigt, dass Mex67 im Komplex mit den Adaptorproteinen von den regulären mRNAs dissoziiert, während es spezifisch und direkt an die Stress-spezifischen Transkripte bindet und diese exportiert. Was unterscheidet nun aber die unterschiedlichen Transkripte? Zu diesem Thema veröffentlichte Zid und O'Shea (2014), dass die Lokalisation der verschiedenen mRNAs unter Glukosemangel von bestimmten Sequenzen in den Promotorregionen abhängt. Sogenannte „,heatshock elements“ (HSE) im Promotorbereich führen zur Bindung des Transkriptionsaktivators Hsf1. HSE-enthaltene mRNAs werden bei Stress bevorzugt translatiert (Zid und O'Shea, 2014).

Um zu untersuchen ob auch reguläre Transkripte bei Stress exportiert werden können, wenn ein Hitzeschockpromotor vorgeschaltet wäre, wurden drei verschiedene Plasmid-Konstrukte mit unterschiedlichen Promotoren hergestellt (Abbildung 37). Das Haushaltsgen CYC1 wurde entweder unter der Kontrolle des Gen-eigenen Promotors oder des Stress-spezifischen Promotors von HSP12 exprimiert. Als Kontrolle diente das Plasmid-Konstrukt mit dem Promotor HSP12 und dem HSP12-ORF. Alle zu testenden Konstrukte enthielten ein C-terminal fusioniertes GFP. Mittels spezifischer Cy3-gekoppelter Sonde gegen die GFP-mRNA konnten die Konstrukte spezifisch in der Zelle über FISH visualisiert werden. Wildtypzellen, die mRNA-Exportmutanten mex67-5 oder mtr2-21, die Mutante der mRNAQualitätskontrolle mtr4-G677D und die Exosommutante rrp64 wurden analysiert. Die Zellen wurden mit den in Abbildung 37 dargestellten Konstrukten $P_{C Y C l}$-CYCl-GFP, $P_{H S P 12}-C Y C 1-G F P$ und $P_{H P 12}-H S P 12-G F P$ transformiert, kultiviert, anschließend, bei $42^{\circ} \mathrm{C}$ für 30 min einem Hitzestress ausgesetzt und fixiert (Abbildung 37). 
a

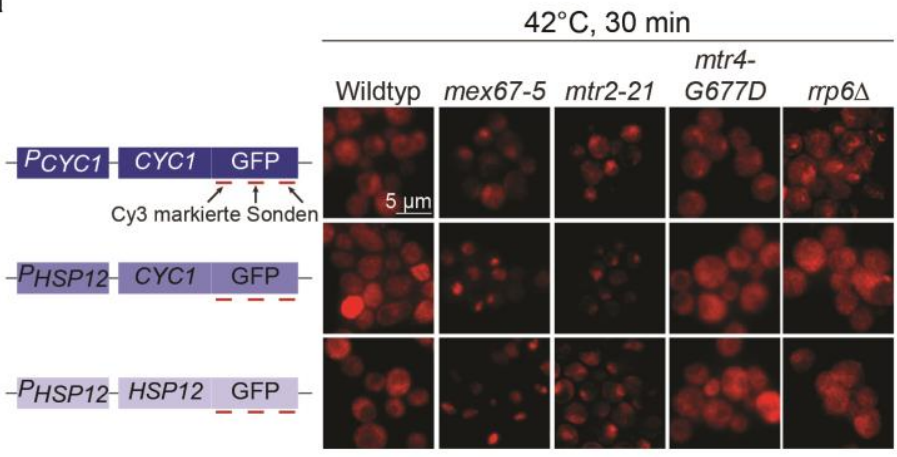

b

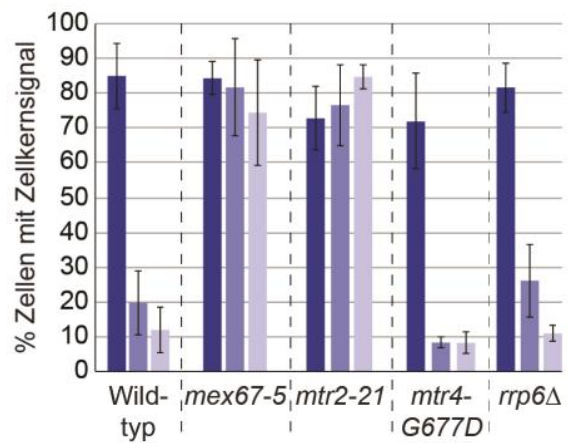

Abbildung 37: Das reguläre CYC1-GFP-Transkript wird unter Kontrolle des HSP12-Promotors bei Hitzestress in das Zytoplasma exportiert. A, FISH Experimente wurden mit Cy3-gekoppelten Sonden gegen die GFP-mRNA durchgeführt. Wildtypzellen, mex67-5 und $m t r 2-21$, sowie $m t r 4-G 6777 D$ und $r r p 64$ wurden mit den entsprechenden Konstrukten $P_{C Y C l}-C Y C 1-G F P, P_{H S P 12}-C Y C 1-G F P, P_{H S P 12}-H S P 12-G F P$ transformiert, kultiviert, wie dargestellt gestresst und sofort fixiert. B, Das Diagramm stellt die Zellkernakkumulation der verschiedenen Mutantenstämme dar. Für jeden Stamm mit jedem Konstrukt wurden 120 Zellen gezählt.

In den mRNA-Exportmutanten mex67-5 und mtr2-21 ist ein deutliches Zellkernsignal aller Transkripte zu erkennen (Abbildung 37). Unabhängig, ob die mRNAs unter der Kontrolle eines regulären Promotors oder eines Stress-spezifischen Promotors stehen, werden die Transkripte im Zellkern in den mRNA-Exportmutanten zurückgehalten. Im Gegensatz dazu kann man im Wildtyp, in der Exosommutante rrp64 und in der Mutante mit defekter mRNAQualitätskontrolle mtr4-G677D eine klare Akkumulation des Haushaltstranskriptes CYC1 (mit Gen-eigenem Promoter) im Zellkern beobachten, während die CYC1-GFP-mRNA unter Kontrolle des HSP12-Promotors in das Zytoplasma exportiert wird. Als Kontrolle des Hitzestress wurde das gleiche Zellmaterial für den direkten Vergleich mit einer Sonde für die poly $(\mathrm{A})^{+} \mathrm{RNA}$ verwendet (Abbildung 38). Zusätzlich sind die Zellkerne durch die DNA gekennzeichnet. 


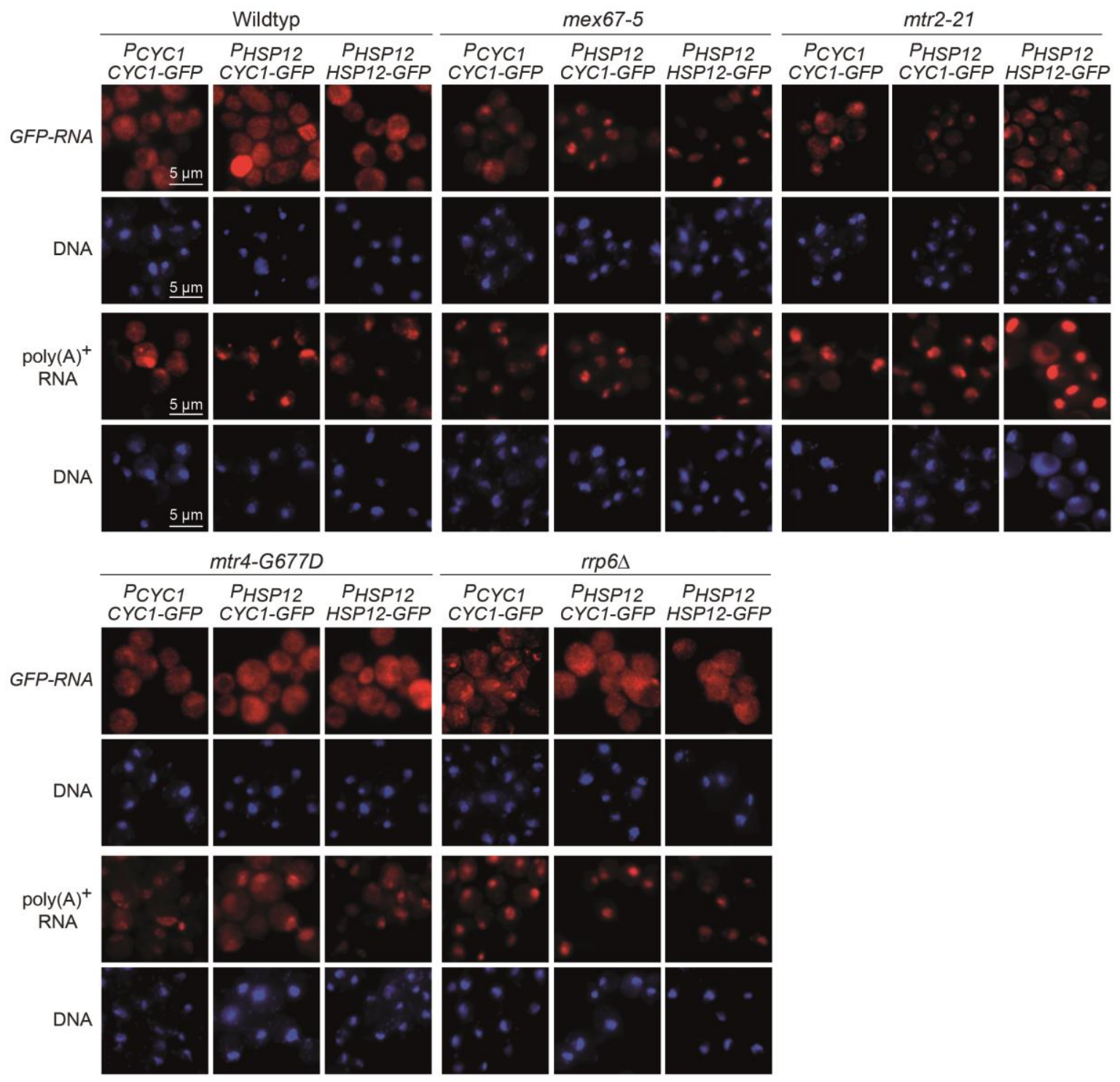

Abbildung 38: Das $\boldsymbol{P}_{\mathrm{HSP12}}$-CYC1-GFP-Transkript wird bei Hitzestress wie eine Stress-mRNA exportiert, während die poly(A) ${ }^{+}$RNA im Zellkern akkumuliert. FISH-Experimente mit Cy3-gekoppelten Sonden gegen die GFP-mRNA und parallel gegen die poly(A) ${ }^{+}$RNA wurden mit Wildtypzellen, mex67-5, mtr2-21, mtr4-G677D und rrp64 Zellen durchgeführt, die mit den entsprechenden Konstrukten $\left(P_{C Y C l}-C Y C 1-G F P\right.$, $P_{H S P 12-C Y C 1-G F P, ~} P_{H S P 12-H S P 12-G F P}$ ) transformiert und bis zur logarithmischen Phase kultiviert wurden. Im Anschluss wurden die Zellen bei $42{ }^{\circ} \mathrm{C}$ für 30 min einem Hitzestress ausgesetzt und fixiert. Die DNA wurde mit Hilfe von Hoechst angefärbt.

Die Abbildung 38 zeigt deutlich, dass die poly(A) ${ }^{+}$RNA und auch die reguläre $C Y C 1-G F P-$ mRNA mit Gen-eigenem Promotor in allen untersuchten Mutanten bei Hitzestress im Zellkern zurückgehalten wurden, während die HSP12-GFP-mRNA spezifisch exportiert wird. Unter Kontrolle des Hitzeschockpromotors des HSP12 Genes wird die CYC1-GFPmRNA bei Stress, in gleicher Weise in das Zytoplasma exportiert, wie das Stress-spezifische HSP12-Transkript (Abbildung 38). Im Gegensatz dazu werden in den mRNAExportmutanten mex67-5 und mtr2-21 alle untersuchten RNA-Transkripte bei Stress im Zellkern zurückgehalten. Dabei wurden die unterschiedlichen Mutanten von Mex67-Mtr2 
für den mRNA-Export und den ribosomalen Export untersucht und es stellte sich heraus, dass unabhängig von der Mutation Mex67 und Mtr2 wichtig für den Transport der Stressspezifischen mRNAs in das Zytoplasma sind.

Darüber hinaus findet keine Akkumulation von falschen oder nicht-prozessierten Transkripten der CYC1-GFP-mRNA unter der Kontrolle des HSP12-Promotors bei Hitzestress in mtr4-G677D und in rrp64 statt. Die CYC1-GFP-mRNA verhält sich unter der Kontrolle des HSP12-Promotors wie ein Stress-spezifisches Transkript.

In der vorliegenden Arbeit sind zusammenfassend folgende Ergebnisse erzielt worden:

1. Die reguläre mRNA wird durch Adaptoren mit dem mRNA-Exportrezeptor verbunden und exportiert. Bei Stress dissoziieren die mRNA-Adaptoren von der poly $(\mathrm{A})^{+} \mathrm{RNA}$ und könnten somit die regulären Transkripte im Zellkern zurückhalten (Abbildung 13; Abbildung 14; Abbildung 15).

2. Die mRNA-Adaptoren werden bei Stress entweder in „,nuclear foci“ (Nab2, Yra1) oder in Super-Aggregaten (Gbp2) im Zellkern gespeichert (Carmody et al., 2010; Wallace et al., 2015). Im Zytoplasma akkumulieren die SR-Proteine gemeinsam mit der zytoplasmatischen mRNA in SGs bei verschiedenen Stressbedingungen. Zusätzlich lokalisiert Npl3 teilweise in PBs bei Hitze- und Salzstress (Abbildung 17).

3. Posttranslationale Modifikationen, beispielsweise potentielle Phosphorylierungen wie bei Nab2 und vermutlich Npl3, könnten für die Dissoziation der mRNAAdaptoren von der poly(A) ${ }^{+}$RNA im Zellkern verantwortlich sein (Carmody et al., 2010; Abbildung 19). Für Npl3 wurden zwei potentielle Stress-spezifische Phosphorylierungen gefunden.

4. Die Adaptoren dissoziieren gemeinsam im Komplex mit dem mRNA-Exportrezeptor Mex67-Mtr2 von der poly(A)+RNA (Abbildung 18; Zander et al., in Revision).

5. Die mRNA-Adaptoren Np13, Nab2, Gbp2 und Hrb1 sind nicht am Export Stressspezifischer mRNAs beteiligt (Abbildung 21) (Carmody et al., 2010; Krebber et al., 1999; Rollenhagen et al., 2007).

6. Mex67 exportiert als Heterodimer gemeinsam mit Mtr2 die Stress-spezifischen mRNAs in das Zytoplasma ohne bisher bekannte mRNA-bindende Adaptoren (Hurt et al., 2000; Abbildung 21).

7. Mex67-GFP und Dbp5-GFP lokalisieren bei Hitzestress am Kernporenkomplex (Abbildung 22). 
8. In MS-Analysen konnten potentielle Proteine identifiziert werden, deren Funktion in der Stressantwort noch nicht näher charakterisiert wurden (Tabelle 14; Tabelle 15).

9. Mex67-Mtr2 kann in vitro an mRNA binden (Santos-Rosa et al., 1998; Abbildung 28). Diese Bindedomäne befindet sich in einer „loop“-Struktur in der NTF2-ähnlichen Domäne. Durch Mutation dieser „loop“-Struktur verringert sich die mRNA-Bindekapazität (Aibara et al., 2015a; Yao et al., 2007; Abbildung 29). Es konnte weiterhin gezeigt werden, dass diese Domäne für den Export von einzelnen Stress-spezifischen mRNAs (SSA4 und HSP12) in das Zytoplasma verantwortlich ist (Abbildung 30; Abbildung 31).

10. Mex67 bleibt an die exportierte Stress-spezifische mRNA im Zytoplasma gebunden und assoziiert dadurch mit dem Translationskomplex (Abbildung 32; Abbildung 33; Abbildung 34).

11. Die Stress-spezifischen mRNAs werden in das Zytoplasma exportiert vermutlich ohne dass sie qualitätskontrolliert werden (Abbildung 35; Abbildung 36; Zander et al., in Revision).

12. Hitzeschockelemente im Promotor Stress-spezifischer Gene kontrollieren die Expression und den Transport der Stress-spezifischen Transkripte in das Zytoplasma (Zid und O'Shea, 2014). So kann eine reguläre mRNA unter der Kontrolle eines Stress-spezifischen Promotors bei Hitzestress in das Zytoplasma exportiert werden. Dazu ist wiederum der mRNA-Exportrezeptor notwendig (Abbildung 37; Abbildung 38). Auch in diesem Fall wird die mRNA-Qualitätskontrolle umgangen und falsche reguläre Transkripte unter der Kontrolle eines Hitzestress-Promotors könnten ebenfalls in das Zytoplasma gelangen (Abbildung 37; Abbildung 38).

Es zeigt sich, dass sich der Export der regulären mRNAs vom Export der Stress-spezifischen mRNAs, wie im Modell gezeigt (Abbildung 39), unterscheidet. 


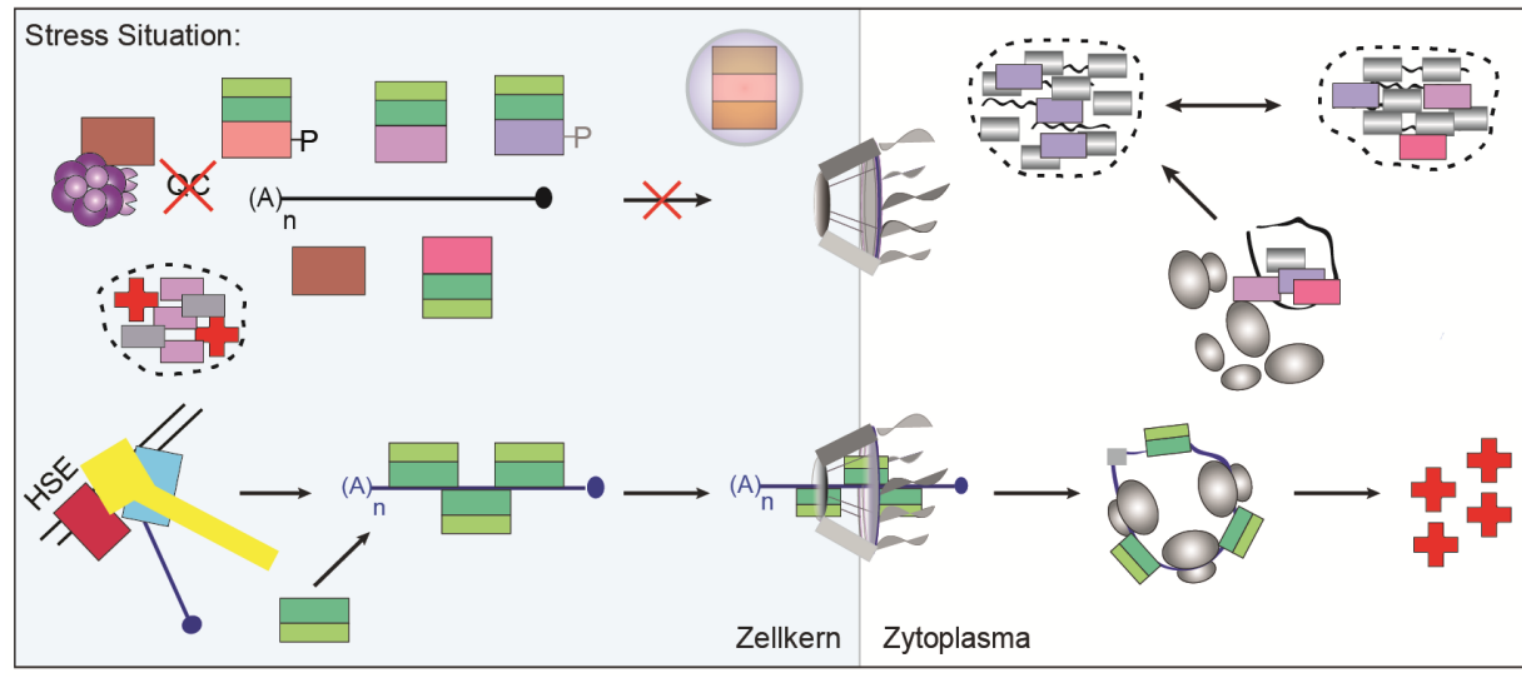

Legende:

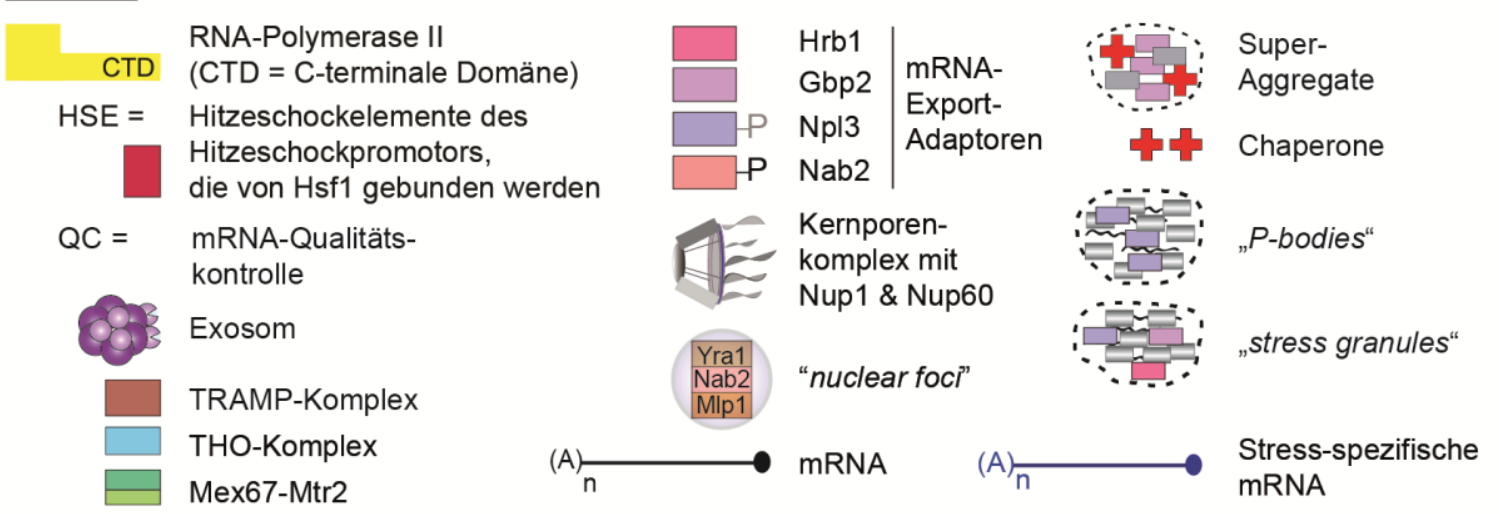

Abbildung 39: Modell für den mRNA-Export bei Stress. Die regulären Transkripte werden im Zellkern durch die Dissoziation der mRNA-Adaptoren im Komplex mit Mex67-Mtr2 zurückgehalten. Gleichzeitig findet der Export der Stress-spezifischen mRNAs in das Zytoplasma statt, der durch den mRNAExportrezeptor Mex67-Mtr2, wahrscheinlich durch eine direkte Bindung an die Transkripte, vermittelt wird. Dabei ist die Entscheidung welche Transkripte exportiert werden vom Hitzeschockpromotor abhängig. Darüber hinaus werden die Stress-spezifischen Transkripte vermutlich ohne mRNA-Qualitätskontrolle exportiert. Im Zytoplasma bleibt Mex67 an die Stress-spezifischen mRNAs bis hin zur Translation gebunden. Die regulären mRNAs werden gemeinsam mit den SR-Proteinen in PBs oder SGs während des Stresses gespeichert. 


\section{Diskussion}

Die zelluläre Kompartimentierung in S. cerevisiae führte zur Trennung von Transkription und Translation und erfordert den selektiven Transport von Proteinen und mRNA zwischen Zellkern und Zytoplasma. Im Zellkern erfolgen die Transkription der DNA und die extensive Prozessierung der prä-mRNA. Während dieser Prozesse liegt die mRNA mit einer Vielzahl von mRNA-Bindeproteinen assoziiert vor. Bei zellulärem Stress werden reguläre Transkripte im Zellkern zurückgehalten und wenn sie sich bereits im Zytoplasma befinden in zytoplasmatischen Granulas gespeichert. Der Transport von Stress-spezifischen mRNAs dagegen unterliegt diesem blockierenden Mechanismus nicht. So werden Stress-spezifische mRNAs weiterhin vom Zellkern in das Zytoplasma transportiert und translatiert.

Der Wechsel zum bevorzugten Transport von stress-spezifischen mRNAs gewährleistet somit eine schnelle Bildung von Hitzeschockproteinen, die vorwiegend als Chaperone fungieren und somit eine umgehende Adaption an die neuen Umweltbedingungen ermöglichen. Nach welchem Mechanismus jedoch Stress-spezifische mRNAs in das Zytoplasma transportiert und translatiert werden, war bisher noch unbekannt. Die vorliegende Arbeit liefert Einblicke in diesen Prozess und charakterisiert einerseits den selektiven Transport von Stress-spezifischen mRNAs und andererseits den Mechanismus, der zum Zurückhalten der poly $(\mathrm{A})^{+} \mathrm{RNA}$ im Zellkern führt.

\subsection{Mechanismen der Dissoziation der Adaptorproteine von der $\operatorname{poly}(\mathrm{A})^{+}$RNA im Zellkern}

In dieser Arbeit wurde untersucht, ob bei zellulärem Stress die mRNA-Adaptoren und der mRNA-Exportrezeptor Mex67-Mtr2 im Zellkern an die poly $(\mathrm{A})^{+} \mathrm{RNA}$ gebunden bleiben oder dissoziieren. Dafür wurde die RNA-Bindefähigkeit der mRNA-Adaptoren bzw. Mex67 bei Stress mittels RIP-Experimenten analysiert (Abbildung 13; Abbildung 14). Interessanterweise zeigen die Ergebnisse, dass während Hitze- und Salzstress eine signifikant reduzierte Bindung der mRNA-Adaptoren und Mex67 an die poly(A) ${ }^{+}$RNA vorliegt (Abbildung 15). Das lässt darauf schließen, dass die mRNA-Adaptorproteine, die unter normalen Wachstumsbedingungen an die regulären Transkripte gebunden sind, bei Stress von der poly $(\mathrm{A})^{+} \mathrm{RNA}$ dissoziieren. Anzumerken ist, dass für die RIP Experimente zu Gbp2 ein verkürzter Hitzestress aufgrund einer Löslichkeitslimitierung angelegt wurde (Abbildung 14). So wird Gbp2 beispielsweise bei Hitzestress in Super-Aggregaten im 
Zellkern gespeichert (Wallace et al., 2015) und ist anscheinend daher nach längerer Hitze und darauffolgendem Zellaufschluss im löslichen Überstand nicht mehr verfügbar (Abbildung 14b). Die RIP Experimente mit Gbp2 zeigen aber, dass bereits nach 7 min bei $42^{\circ} \mathrm{C}$ eine Reduktion in der Bindung von Gbp2 an die poly(A) $)^{+} \mathrm{RA}$ nachzuweisen ist (Abbildung 14b). Diesbezüglich scheinen 7 min Hitzestress für das Ablösen der mRNAAdaptoren von der poly $(\mathrm{A})^{+} \mathrm{RNA}$ auszureichd zu sein und weshalb die regulären mRNAs wahrscheinlich im Zellkern zurückgehalten werden. Die reduzierte Bindung von Gbp2 an die mRNAs bei Salzstress entspricht den der anderen Adaptoren. Das deutet darauf hin, dass bei Salzstress andere regulierende Mechanismen von der Zelle durchgeführt werden als bei Hitzestress.

Bei Hitzestress konnte eine veränderte Lokalisation auch bei anderen RNA-Bindeproteine im Zellkern gezeigt werden. So akkumulieren Mlp1, Nab2 und Yra1 bei Hitzestress in „nuclear foci“ (Carmody et al., 2010; Abbildung 22). Da diese „nuclear foci“ kleinere Komplexe sind, können Nab2 und Yra1 im Gegensatz zu Gbp2 weiterhin löslich im Überstand nachgewiesen und präzipitiert werden (Abbildung 13).

Da bei Stress die regulären Transkripte im Zellkern zurück gehalten werden (Saavedra et al., 1996) und die mRNA-Adaptoren von der poly(A) ${ }^{+}$RNA im Zellkern dissoziieren (Abbildung 15), wurde die Lokalisation der mRNA-Adaptoren, im Speziellen die der SR-Proteine, bei Stress mittels GFP-Mikroskopie untersucht. Dazu wurden zytoplasmatische Versionen der SR-Proteine genutzt, die eine gleichmäßige Verteilung des GFP-Signals in der Zelle gewährleisten (Gilbert et al., 2001; Hacker und Krebber, 2003; Hackmann et al., 2014). Die Ergebnisse im Wildtyp zeigen, dass die Lokalisation von Npl3, Hrb1 oder Gbp2 bei Stress im Vergleich zu normalen Wachstumsbedingungen entweder unverändert bleibt oder der Protein ,,pool“ in das Zytoplasma lokalisiert (Abbildung 16). In der mRNA-Exportmutante rat7-1 wird die poly(A) ${ }^{+} \mathrm{RNA}$ bei $37^{\circ} \mathrm{C}$ und bei zellulärem Stress nahezu vollständig im Zellkern zurückgehalten (Abbildung 16; Gorsch et al., 1995; Thomsen et al., 2003). Bei $37^{\circ} \mathrm{C}$ bleiben die $\mathrm{SR}_{\mathrm{c}}$-Proteine an die poly(A) ${ }^{+} \mathrm{RNA}$ gebunden und dementsprechend akkumulieren sie im Zellkern, doch bei Hitze-, Salzstress oder Glukosemangel findet eine Dissoziation der $\mathrm{SR}_{\mathrm{c}}$-Proteine von der poly $(\mathrm{A})^{+} \mathrm{RNA}$ statt und die Proteine diffundieren frei in der Zelle (Abbildung 16). Diese Beobachtungen konnten bereits mit einer Mutante von NPL3 (npl3-27) gezeigt werden, die ebenfalls bei Hitze- und Salzstress ins Zytoplasma lokalisiert (Krebber et al., 1999). Da auch das mRNAAdaptorprotein Nab2 eine veränderte Lokalisation während des Stresses in „,nuclear foci“ zeigte (Abbildung 22; Carmody et al., 2010), verlieren die mRNA-Adaptoren vermutlich 
ihre mRNA-Bindefähigkeit im Zellkern und lokalisieren in der Zelle so, dass sie nicht mehr am Export von mRNA beteiligt sind. Weitere Hinweise deuten darauf hin, dass die mRNAAdaptoren Np13, Nab2, Gbp2 und Hrb1 im Zellkern von der poly(A) ${ }^{+}$RNA dissoziieren, ihre physikalische Interaktion mit dem mRNA-Exportrezeptor Mex67 jedoch weiter bestehen bleibt (Abbildung 18 und Zander et al., in Revision). Diese Interaktion scheint RNA-und Stress-unabhängig zu sein. Aus diesem Grund könnte es sein, dass die mRNABindefähigkeit der mRNA-Adaptoren im Zellkern während des Stresses, z. B. durch Modifikationen oder durch Speicherung in Aggregaten, verringert wird.

Auch posttranslationale Modifikationen könnten eine Rolle bei der Dissoziation der mRNAAdaptoren von den regulären mRNAs spielen. Und in der Tat konnte bei Nab2 bereits gezeigt werden, dass es während Hitzestress phosphoryliert vorliegt, wodurch es vermutlich von der poly $(\mathrm{A})^{+} \mathrm{RNA}$ dissoziiert wird (Carmody et al., 2010). Interessanterweise werden die Aminosäurereste Threonin-178 und Serin-180 von Nab2 (in der Glutamin-reichen QQQP-Domäne) phosphoryliert, während Mex67 mit den darauffolgenden RGG- und Zinkfinger-Domänen physikalisch interagiert (Iglesias et al., 2010; Abbildung 6). Derzeit ist noch unklar, wofür die QQQP-Domäne verantwortlich ist, da die poly $(\mathrm{A})^{+} \mathrm{RNA}-\mathrm{Bindung}$ im C-terminalen Bereich von Nab2 (der Zinkfinger-Domäne - Nab2-ZnF5-7) stattfindet. Vielleicht ist die QQQP-Domäne für den strukturellen Aufbau von Nab2 wichtig und durch die Phosphorylierung kommt es zu einer Konformationsänderung von Nab2 und somit zur Dissoziation des Proteins von der poly(A) ${ }^{+}$RNA. Bei Stress könnten Phosphorylierungen auch bei den anderen mRNA-Adaptorproteinen eine Rolle spielen und die RNA-Bindung im Zellkern stören und so die Proteine von der poly(A)+RNA dissoziieren. Es wurde z. B. auch gezeigt, dass die Phosphorylierung von Npl3 am Aminosäurerest Serin-411 die Interaktion von Mex67 im Zellkern vermindert und im Zytoplasma den Rücktransport von Npl3 in den Zellkern begünstigt (Gilbert und Guthrie, 2004; Gilbert et al., 2001). Deshalb wurden MS-Analysen initial mit Npl3 durchgeführt. Während Hitze- und Salzstress konnte eine Phosphorylierungsstelle in der SR-reichen C-terminalen Domäne von Npl3 identifiziert werden. Da es sich bei dieser Stelle aber um eine identische Sequenzwiederholung handelt (Abbildung 19b), die durch das Schneiden der Polypeptidkette mit Trypsin nach Argeninresten entsteht (Abbildung 19b), lässt sich nicht genau einordnen welche Aminosäurereste entweder Serin-349 oder Serin-356 durch Stress phosphoryliert vorliegen. Aus diesem Grund müssten in weiteren Experimenten die genaue Phosphorylierungsstelle identifiziert werden, indem beispielsweise andere Proteasen getestet werden, die andere Schnittstellen in der Proteinsequenz von Npl3 erkennen und somit unterschiedliche 
Peptidstücke erzeugen. Im Folgenden müsste dann untersucht werden, ob die Phosphorylierung von Npl3 während Stress die poly(A) ${ }^{+}$RNA-Bindung beeinflusst. Dies könnte durch die Erzeugung von Npl3-Versionen mit ausgetauschten Phosphatstellen zu Alanin und Glutaminsäure untersucht werden. Bei diesem Austausch der Phosphatstellen sollte die phosphomimetische Mutante die mRNA verringert binden können und der Aminosäureaustausch zu Alanin sollte eine verstärkte mRNA-Bindung auch während Stress zur Folge haben.

Aufgrund der identifizierten Phosphorylierungsstelle bei Npl3, stellt sich die Frage, ob Gbp2 und Hrb1 ebenfalls im Zellkern während Stress phosphoryliert werden oder ob andere posttranslationale Modifikationen der Proteine stattfinden. Bei Gbp2 könnte es durch die Aggregatbildung im Zellkern dazu kommen, dass das Protein für solche Modifikationsprozesse nicht mehr zur Verfügung steht (Wallace et al., 2015; Abbildung 14b). Es könnte aber auch durch posttranslationale Modifikationen zu einer Aggregatbildung kommen, dazu müssten die durch Stress entstandenen Aggregate und deren aggregierende Proteine beispielsweise durch ,proteome-wide aggregation profilin“ näher untersucht werden (Wallace et al., 2015). In diesem Experiment kann man das Pellet vom Überstand mit Hilfe von $2 \%$ SDS und 8 M UREA trennen und dann durch Massenspektroskopie analysieren.

\subsection{Die SR-Proteine lokalisieren in ,stress granules" und „P-bodies“}

Während im Zellkern kein mRNA-Export bei Stress stattfindet, werden die regulären mRNAs im Zytoplasma in verschiedenen Granulas (SGs und PBs) gespeichert (Anderson und Kedersha, 2006; Sheth und Parker, 2003). Die SR-Proteine pendeln unter normalen Wachstums-bedingungen mit der regulären mRNA in das Zytoplasma und liegen dort an die Polysomen assoziiert vor (Baierlein et al., 2013; Windgassen et al., 2004). So können die SR-Proteine bei Glukosemangel ebenfalls mit der zytoplasmatischen mRNA in SGs (,stress granules $^{\text {") }}$ lokalisiert werden (Buchan et al., 2008; Mitchell et al., 2013; Abbildung 17). Zusätzlich konnte in dieser Arbeit gezeigt werden, dass die SR-Proteine auch bei Hitze- und Salzstress in SGs lokalisieren (Abbildung 17). Darüber hinaus konnte bei Npl3 beobachtet werden, dass das Protein zudem in PBs (,P-bodies $\left.{ }^{6}\right)$ co-lokalisiert, während Gbp2 und Hrb1 scheinbar ausschließlich mit SGs assoziiert vorliegen (Abbildung 17). Dabei scheint sich in diesen Ergebnissen ein Unterschied zwischen Npl3 und Gbp2/Hrb1 zu ergeben. Es konnte für Npl3 bereits eine zusätzliche Funktion in der 80S-Monosomenformierung (,,ribosomes 
subunit joining“") zu geschrieben werden (Baierlein et al., 2013). Außerdem wurde gezeigt, dass Npl3 am Transport der ribosomalen prä-60S-Untereinheit beteiligt ist (Hackmann et al., 2011). Diese zusätzlichen Aufgaben könnten auf die erweiterte Lokalisation von Npl3 während Hitze- und Salzstress in PBs hindeuten.

Ähnlich wie die Translationsfaktoren eIF4G und Pab1 werden auch die SR-Proteine in den SGs gespeichert (Abbildung 17; Hoyle et al., 2007) und könnten nach überstandener Stresssituation wieder der Translation zugeführt werden (Hoyle und Ashe, 2008). Im Gegensatz dazu wird Nab2 unter normalen Wachstumsbedingungen direkt am NPC durch Dbp5 von der mRNA abgelöst und ist dadurch nicht an die translatierten mRNAs assoziiert (Tran et al., 2007). Bei Hitzestress und Glukosemangel lokalisiert Nab2 ausschließlich im Zellkern, so dass ein zytoplasmatischer ,pool“ von Nab2 bei zellulärem Stress nicht vermutet wird (Carmody et al., 2010; Mitchell et al., 2013).

\subsection{Qualitätskontrolle des mRNA-Exportes}

Die in dieser Arbeit zugrunde liegenden Ergebnisse zeigen, dass die bisher bekannten mRNA-Adaptoren bei Stress keine mRNA-Exportfunktionen in der Zelle übernehmen. Diesbezüglich konnte gezeigt werden, dass die Hitzestress-mRNAs SSA4 und HSP12 in Deletionsmutanten oder teilweise deletierten Mutanten der pendelnden mRNA-Adaptoren weiterhin in das Zytoplasma transportiert werden (Abbildung 21). Die dargestellten Ergebnissen werfen folgende Frage auf: Warum exportieren die mRNA-Adaptoren Npl3, Gbp2, Hrb1 und Nab2 reguläre Transkripte in das Zytoplasma, wenn sie für den Transport von Stress-spezifischen mRNAs nicht benötigt werden? Es wäre möglich, dass die Adaptoren als mRNA-Qualitätskontrollfaktoren fungieren. Das bedeutet, dass sie zu unterschiedlichen Zeitpunkten kontrollieren, dass die mRNAs korrekt transkribiert und prozessiert vorliegen. In der Tat wurde gezeigt, das Gbp2 und Hrb1 gespleißte mRNAs binden können und falsch prozessierte RNAs durch Interaktion mit dem TRAMP4-Komplex dem Abbau durch das Exosom zuführen oder korrekte mRNAs durch Assoziation mit Mex67-Mtr2 zum Export freigeben können (Hackmann et al., 2014). Für Nab2 wurde gezeigt, dass es die Länge des poly(A)-Schwanzes kontrolliert und dass beim Fehlen von Nab2 eine Hyperadenylierung der mRNAs stattfindet (Batisse et al., 2009). Zusätzlich konnte gezeigt werden, dass Nab2 bei der mRNA-Synthese um die entstehenden poly $(\mathrm{A})^{+}-$ Transkripte mit Rrp6 konkurriert. Durch eine schnelle Depletion des Nab2 Proteins wurden die regulären mRNAs durch das nukleäre Exosom (besonders Rrp6) umgehend abgebaut (Schmid et al., 2015). 
Um zu analysieren, ob bei Hitzestress falsche Stress-spezifische mRNAs im Zellkern zurïckgehalten und ebenfalls abgebaut werden, wurden FISH Experimente in einem RRP6 Deletionsstamm (einer nukleären Exosommutante) und in einer poly $(\mathrm{A})^{+} \mathrm{RNA}$ akkumulierenden MTR4 Mutante (mtr4-G677D) als Teil des TRAMP-Komplexes durchgeführt. Untersucht wurden Stress-spezifische Transkripte während unterschiedlich langem Hitzestress (Abbildung 35; Abbildung 36). Doch weder nach 30 Minuten, noch nach einem 60 minütigen Hitzestress findet eine Akkumulation von SSA4 oder HSP12 im Zellkern statt (Abbildung 36). Falls nicht-prozessierte oder falsche Stress-Transkripte hergestellt wurden, konnten sie als solche nicht markiert und damit nicht im Zellkern zurückgehalten werden. Das deutet darauf hin, dass die Transkripte unabhängig davon, ob sie korrekt sind oder nicht in das Zytoplasma exportiert werden. Reguläre Transkripte, die falsch oder nichtprozessiert sind, akkumulieren im Vergleich dazu unter normalen Wachstumsbedigungen in diesen Mutanten (Abbildung 35; Rougemaille et al., 2007; Thomsen et al., 2003). Da die falschen Transkripte durch die Bindung der mRNA-Adaptoren im Zellkern akkumulieren, wurde in einem weiteren Experiment gezeigt, dass in dem Deletionsstamm von RRP6 falsche poly $(\mathrm{A})^{+} \mathrm{RNA}$ bei $37^{\circ} \mathrm{C}$ im Zellkern akkumuliert, während in Kombination mit den Deletionsstämmen der pendelnden mRNA-Adaptoren diese Akkumulation signifikant geschwächt wird (Zander et al., in Revision). Das legt nahe, dass die Adaptoren mit den mRNA-Qualitätskontrollfaktoren interagieren und nicht-korrekte mRNAs dem Abbau zuführen könnten, während korrekte mRNAs durch Bindung des mRNA-Exportrezeptors Mex67-Mtr2 in das Zytoplasma transportiert werden (Hackmann et al., 2014).

FISH Experimente mit spezifischen Sonden gegen SSA4 und HSP12 zeigten, dass nicht nur die mRNA-Adaptoren beim Export der Stress-mRNA keine Funktion haben, sondern auch dass die mRNA-Qualitätskontrolle bei Stress abgeschaltet ist (Abbildung 36; Zander et al., in Revision). Weiterhin wurde gezeigt, dass die mRNA-Adaptoren genetisch mit der mRNA-Qualitätskontrolle interagieren (Hackmann et al., 2014). Neben diesen Ergebnissen wurde bereits gezeigt, dass die mRNA-Adaptoren $\mathrm{zu}$ verschiedenen Zeitpunkten in physikalischer Interaktion oder in direkter Konkurrenz um die entstehenden Transkripte mit dem TRAMP-Komplex (Mtr4), dem nukleären Exosom (Rrp6) und der Qualitätskontrolle am Kernporenkomplex (mit Mlp1/2) stehen (Hackmann et al., 2014; Niepel et al., 2013; Schmid et al., 2015; Vinciguerra et al., 2005). 


\subsection{Der direkte Mex67-vermittelte Export von Hitzestress-mRNAs}

\subsubsection{Interaktionspartner von Mex67 bei Hitze- oder Salzstress}

Mex67 exportiert die Hitzestress-mRNAs ohne die bisher bekannten Adaptorproteine in das Zytoplasma. Daher stellt sich die Frage, ob weitere bisher unbekannte Adaptoren für Mex67 und Mtr2 am Export der Stress-spezifischen mRNAs beteiligt sind. Aus diesem Grund wurde nach unbekannten Proteinen gesucht, die mit Mex67 interagieren.

Als Interaktionspartner von Mex67 bei Salzstress wurde Gle2 identifiziert, das interessanterweise bei Hitzestress vom NPC abgelöst wird (Tabelle 14) (Izawa et al., 2004). Eine weitere Veröffentlichung stellte zudem in Wachstumsanalysen dar, dass Zellen mit einer GLE2 Deletion bei 1,2 M Natriumchlorid oder bei 2 M Sorbitol im Vergleich zum Wildtyp nicht mehr überleben können (Regot et al., 2013). Die Autoren konnten weiterhin zeigen, dass Gle2 und weitere Proteine des NPCs für die Expression von Salzstress-mRNAs wichtig sind. Das deutet auf eine Funktion von Gle2 während Salzsstress hin. Weitere Analysen, wie z. B. FISH Experimente könnten klären, ob Stress-spezifische Transkripte in gle2A Zellen während Salzsstress noch exportiert werden oder ob sie im Zellkern akkumulieren.

Weitere Proteine, die als mögliche Adaptoren fungieren könnten, sind Dbp3 und Yra2. Sie wurden ebenfalls vorrangig bei Salzstress identifiziert (Tabelle 14) und es handelt sich um RNA-Bindeproteine (Garcia und Uhlenbeck, 2008; Zenklusen et al., 2001). In Wachtumsanalysen zeigten $d b p 3 \Delta$ Zellen einen leichten Wachstumsdefekt nach 20 minütigen Hitzeschock bei $52^{\circ} \mathrm{C}$ (Abbildung 24a). Die Zellen ohne DBP3 regenerierten sich schlechter als die wildtypischen Zellen. Des Weiteren konnte eine verstärkte Bindung von Dbp3 mit Mex67 während Salzstress im Vergleich zu $25^{\circ} \mathrm{C}$ detektiert werden (Abbildung 24c). In weiteren Experimenten könnte man die Lokalisation der Stressspezifischen mRNAs in dbp3 $\triangle$ Zellen analysieren. Während man den Kernporenkomplex anfärbt, könnte dabei untersucht werden, ob Stress-spezifische mRNAs in den $d b p 3 \Delta$ Zellen während Salzstress noch in das Zytoplasma transportiert werden oder ob sie im Zellkern akkumulieren,. Eine weitere Frage wäre, ob Dbp3 mit Stress-spezifischen mRNAs interagiert und diese selbst in das Zytoplasma exportiert. Hierzu könnte man das Dbp3Protein präzipitieren und die gebundene mRNA extrahieren und durch qPCRs analysieren, welche Transkripte an Dbp3 während Salzstress gebunden haben. Interessanterweise lokalisiert Dbp3-GFP während eines zehn- oder zwanzig-minütigen Hitzestresses bei $42^{\circ} \mathrm{C}$ neben den Zellkern in einer ringförmigen Struktur (Abbildung 24). Jedoch konnte Dbp3 bei 
Hitzestress nicht in Immunpräzipitationsexperimenten aufgereinigt werden und deshalb konnte keine Interaktion mit Mex67 festgestellt werden. Diese ringförmigen Strukturen konnten bereits bei ribosomalen Proteinen wie Rpl25-GFP oder Rps2-GFP beobachtet werden (Daten nicht gezeigt). Ob diese Struktur auf den Nukleolus begrenzt ist, müsste durch Co-Lokalisationsstudien mit Nop1 (einem nukleolären Protein) untersucht werden.

Es könnte sich aber auch um eine Ansammlung an Proteinen handeln, die eine schnelle und erleichterte Translation der Stress-spezifischen mRNAs veranlassen. Da sich diese Struktur neben der DNA befindet, könnten die exportieren Stress-spezifischen Transkripte direkt nach Export translatiert werden. Dazu müssten diese Ringstrukturen näher auf ihre Zusammensetzung hin untersucht werden. Co-Lokalisation mittels Mikroskopie-Studien könnten durchgeführt werden oder man versucht die Proteine, die in diesen ringförmigen Strukturen lokalisieren, aufzureinigen und untersucht welche weiteren Faktoren oder RNAs in dieser Struktur neben dem Zellkern enthalten sind.

Die Ergebnisse für Yra2 zeigen, ähnlich zu den Ergebnissen von Yra1 (Zander et. al., in Revision), dass Yra2 im Komplex mit Mex67 von der poly(A) ${ }^{+}$RNA im Zellkern dissoziieren könnten und deshalb als Interaktionspartner von Mex67 identifiziert werden konnte (Abbildung 25). Aus diesem Grund konnte auch das mRNA-Adaptorprotein Nab2 bei Hitzestress als Interaktionspartner identifiziert werden (Tabelle 14). Durch die gemeinsame Dissoziation der Proteine von der poly $(\mathrm{A})^{+} \mathrm{RNA}$ im Zellkern könnte sich die bestehende Interaktion der mRNA-Adaptoren mit Mex67 während Stress erklären lassen (Abbildung 13; Abbildung 18).

Weitere interessante Kandidaten, die als Interaktionspartner von Mex67 identifizert wurden, sind bei Hitzestress Ssz1 und bei Salzstress Ssc1. Durch ihre Zugehörigkeit zur Hsp70Familie und durch ihre unterstützende Funktion während der Translation als ,ribosomeassociated complex“ (RAC) (Gautschi et al., 2002; Rakwalska und Rospert, 2004), könnten sie eine potentielle Rolle in der Translation der Stress-spezifischen Transkripte spielen. Da Mex67 an die Transkripte im Zytoplasma gebunden bleibt, könnte sich die Proteininteraktion mit den Chaperonen während der Translation ereignen. Doch sind zusätzliche unbekannte Funktionen von Ssc1 und Ssz1, in denen sie beim mRNA-Transport mit Mex67 interagieren, nicht ausgeschlossen. Solche Funktionen könnten überprüft werden, indem Wachstumsanalysen mit den Deletionsstämmen von SSZ1 und SSC1 nach einem Hitzeschock und während Salzstress durchgeführt werden. Des Weiteren könnte der mRNA-Transport in den Deletionsstämmen während Stress analysiert werden. Außerdem stellt sich die Frage, ob die beiden Proteine zwischen Zellkern und Zytoplasma pendeln. 
Dazu könnte man einen „shuttling assay“ durchführen, der untersucht, ob sich die Lokalisation von Proteinen in der Zelle ändern kann (Lee et al., 1996). In weiteren Analysen könnte die mRNA-Bindung der beiden Proteine untersucht und die Interaktion mit Mex67 bestätigt werden. Diese Experimente könnten einen Einblick geben, ob die Hitzeschockproteine Ssc1 und Ssz1 einen Einfluss auf den Export von Stress-spezifischen Transkripten haben.

Zusammenfassend wurden neue und bisher unbekannte Proteine identifiziert, die mit Mex67 unter normalen Wachstumsbedingungen, aber auch während Hitze- oder Salzstress interagieren. Bei den identifizierten Proteinen könnte es sich um artifizielle Bindung an Mex67 handeln, deshalb müssen die Proteine mit weiteren bereits beschriebenen Experimenten untersucht werden. Bisher wurde jedoch kein weiteres eindeutiges Adaptorprotein gefunden, dass darauf hinweist am Transport der Stress-spezifischen mRNAs in das Zytoplasma beteiligt zu sein.

\subsubsection{Proteine, die mit der Hitzestress-mRNA HSP12 interagieren}

Um Proteine zu identifizieren, die mit Stress-spezifischen mRNAs nach Hitzestress assoziiert sind und an deren Export beteiligt sein könnten, wurde die HSP12-mRNA, die mit MS2 „stemloops“ (MSIIL) fusioniert waren, affinitätsgereinigt (Abbildung 26; Abbildung 27). Anschließend wurden die Proben für massenspektroskopische Analysen verwendet und in Tabelle 15 sind alle identifizierten Proteine dargestellt. Ähnlich wie bei der Interaktion von Mex67-GFP bei Stress, assoziieren viele ribosomale Proteine an die HSP12-MSIILmRNA, außerdem binden verstärkt Hitzeschockproteine, wie z. B. Zuo1 oder Ssa3. Diese Interaktionen an die HSP12-MSIIL-mRNA könnten durch unspezifische Bindung entstanden sein. Ebenso unspezifisch könnten einige RNA-Bindeproteine, wie z. B. Yra1 oder Scp160 an die HSP12-MSIIL-mRNA binden. Ob Yra1 bei der Beladung von Mex67Mtr2 auf die mRNA beteiligt ist oder unspezifisch an die HSP12-MSIIL-mRNA bindet, müsste in weiteren Analysen untersucht werden.

Da Scp160 bereits als RNA-Bindeprotein (Lang und Fridovich-Keil, 2000; Li et al., 2003) und als Transporter für spezifische mRNAs zur Knospenspitze der Tochterzelle identifiziert wurde (Gelin-Licht et al., 2012; Guo et al., 2003), bleibt die Frage ob es eine Transportfunktion für die HSP12-MSIIL-mRNA übernimmt. In weiteren Untersuchungen müsste geklärt werden, ob Scp160 im Zellkern auf die mRNA geladen wird oder ob die Interaktion erst im Zytoplasma stattfindet. Interessanterweise besitzt Scp160 ein potentielles „nuclear import signal“ (NLS) und ein potentielles ,nuclear export signal“ (NES) und 
könnte so bereits im Zellkern eine Funktion im Export von mRNAs einnehmen (Frey et al., 2001; Weber et al., 1997). Unter normalen Wachstumsbedingungen lokalisiert Scp160 im Endoplasmischen Retikulum, doch kann das Protein, während Glukosemangel im Zytoplasma verteilt, beobachten werden (Mitchell et al., 2013). Demzufolge könnten Analysen zur Funktion von Scp160 bei Stress im Zytoplasma einen Aufschluss über die Lokalisation und die Aufgaben des Proteins im Zytoplasma geben.

Hsp26 ist ein weiteres Protein, das als Interaktionspartner von der HSP12-MSIIL-mRNA und von Mex67 in den MS-Datenanalysen identifiziert (Tabelle 14; Tabelle 15) und zudem bereits als RNA-Bindeprotein charakterisiert wurde (Tsvetanova et al., 2010). Dieses Protein wurde in der Bachelorarbeit von Berfin Tuku aus der Arbeitsgruppe von Prof. Dr. H. Krebber näher untersucht. Dabei stellte sich heraus, dass das Protein ähnlich wie Dbp3 während Hitzestress nicht mehr löslich im Überstand detektiert wurde. Außerdem lokalisierte es ebenfalls neben dem Zellkern in einer ring-ähnlichen Struktur. Falls es am Transport der Stress-spezifischen mRNAs eine Rolle spielt, könnte es eventuell die RNA in räumliche Nähe mit den ribosomalen Proteinen bringen und es könnte so eine schnelle Translation der Stress-spezifischen mRNAs veranlassen. Da Hsp26 aber auch als Chaperon fungiert, könnte es unterstützend bei der Translation einen Einfluss haben. Die Frage bleibt offen, wo Hsp26 mit der HSP12-MSIIL-mRNA interagiert. In weiteren Analysen könnte untersucht werden, ob Hsp26 bereits im Zellkern auf die mRNA geladen wird oder ob das Protein erst im Zytoplasma mit der mRNA assoziiert vorliegt. Dafür könnte eine Zellfraktionierung durchgeführt werden und die HSP12-MSIIL-mRNA auf interagierende Faktoren einerseits im Zellkern und andererseits im Zytoplasma hin untersucht werden. In dieser Arbeit konnten verschiedene Proteine identifiziert werden, die bei Hitze- oder Salzstress an Mex67 oder an die HSP12-MSIIL-mRNAs gebunden sind. Doch lässt sich derzeit nicht ausschließen, dass die identifizierten Interaktionspartner unspezifisch an die mRNA binden. Aus diesem Grund müssten weitere Experimente durchgeführt werden, um die Bindung der Proteine an die mRNA bei Stress zu bestätigen.

\subsubsection{Mex67-Mtr2 bindet direkt an Hitzestress-mRNAs}

Neben den verschiedenen Analysen zur Identifikation weiterer Adaptorproteine unter verschiedenen Stresssituationen, wurde die Möglichkeit der direkten Bindung von Mex67Mtr2 an Stress-spezifische mRNAs untersucht. Bereits verschiedene Veröffentlichungen zeigten, dass Mex67-Mtr2 in vitro direkt an RNA binden kann (Aibara et al., 2015; Santos-Rosa et al., 1998; Yao et al., 2007). In diesen Studien konnten Mex67-Mtr2 
spezifische Bindungsaffinitäten zur 5S rRNA, zu viraler RNA und zu synthetischhergestellter RNA dargestellt werden. Doch wurde bisher nicht untersucht, ob Mex67-Mtr2 auch direkt mRNA binden kann und was das für Auswirkungen auf den Transport der mRNAs hat. Deshalb wurde in dieser Arbeit rekombinantes Mex67-Mtr2 auf die Bindungseigenschaft von regulären und Stress-spezifischen Transkripten hin untersucht. Dabei konnte gezeigt werden, dass Mex67-Mtr2 in vitro starke mRNA-Bindungsaffinitäten besitzt (Abbildung 28b) und darüber hinaus bindet es ähnlich stark die untersuchten Transkripte wie das mRNA-Bindeprotein Np13. Zusätzlich konnte in dem in vitro Ansatz durch Co-Präzipitation gezeigt werden (Abbildung 28a), dass Mex67 im Komplex mit Mtr2 bestehen bleibt. Wenn Mex67 allein aufgereinigt wird, präzipitiert es und kann nicht verwendet werden, doch führt man eine Co-Expression von Mex67 mit Mtr2 durch, bleiben beide Proteine löslich und stabil (Abbildung 28a).

Außerdem wurde in verschiedenen Veröffentlichungen gezeigt, dass eine spezifische RNABindedomäne, eine ,loop“-Struktur, die ausschließlich in Hefe vorkommt, existiert (Aibara et al., 2015; Yao et al., 2007). Eine Deletion dieser „loop“-Struktur oder ein Aminosäureaustausch von Lysin oder Arginin zu Alanin innerhalb dieser Domäne führt zu einer signifikanten Verringerung der mRNA-Bindefähigkeit (Abbildung 29b), was auch in vorangegangenen Veröffentlichungen für andere RNAs gezeigt wurde (Aibara et al., 2015; Yao et al., 2007). Diese Arbeit zeigt, dass Mex67-Mtr2 durch die „loop“-Struktur auch mRNAs ohne zusätzliche Faktoren in vitro binden kann.

In FISH Experimenten wurde weiterhin untersucht, ob die direkte mRNA-Bindung für den Export der Stress-spezifischen mRNAs wichtig ist. In der Tat konnte gezeigt werden, dass in den ,loop“-Mutanten von Mex67 die Stress-spezifischen mRNAs SSA4 und HSP12 bei Hitzestress nicht mehr vollständig exportiert werden (Abbildung 30; Abbildung 31). Das deutet auf die Notwendigkeit einer direkten Bindung der mRNA an Mex67-Mtr2 in vivo hin (Abbildung 30; Abbildung 31). Aus diesen Ergebnissen lässt sich ableiten, dass der Exportrezeptor bei Hitzestress möglicherweise nicht auf Adaptorproteine angewiesen ist, sondern direkt Stress-spezifische mRNAs binden und diese in das Zytoplasma transportieren kann. Damit scheint sich der mRNA Transport unter normalen Wachstumsbedingungen von dem unter Stressbedingungen zu unterscheiden. Zwar benötigen beide Transportwege den heterodimeren Exportrezeptor Mex67-Mtr2, aber wie die mRNAs exportiert werden, ist unterschiedlich. Möglicherweise gewährleistet die direkte Bindung von Mex67-Mtr2 an die Stress-spezifischen mRNAs deren schnellen Export, sodass eine zügige Adaption an die Stresssituation erreicht werden kann. 


\subsection{Mex67 wird bei Hitzestress nicht durch Dbp5 von Hitzestress-mRNAs dissoziiert}

Unter normalen Wachstumsbedingungen wird Mex67 durch Dbp5 von den mRNAAdaptorproteinen gelöst und so die Direktionalität des mRNA Transportes hergestellt (Tieg und Krebber, 2012). Da Mex67 für den Transport von Hitzestress-mRNAs keine Adaptoren benötigt, stellt sich die Frage, ob Mex67 am Kernporenkomplex auch durch Dbp5 dissoziiert wird. Zusätzlich ist Mex67 auch am Ribosomentransport beteiligt und dabei wird es nicht von Dbp5 am NPC abgelöst (Neumann et al., 2016). In Abbildung 32 konnte gezeigt werden, dass Mex67 bei $25^{\circ} \mathrm{C}$ aber auch bei $42^{\circ} \mathrm{C}$ mit den polysomalen Fraktionen präzipitiert wurde. Doch im Unterschied zur regulären Bindung von Mex67 an die Polysomen, zeigten die Ergebnisse bei Hitzestress $\left(42^{\circ} \mathrm{C}\right)$, dass Mex67 über die Hitzestress-mRNAs im Translationskomplex detektiert werden kann (Abbildung 33b; Abbildung 34). Die Ergebnisse deuten darauf hin, dass die Stress-spezifischen mRNAs durch direkte Bindung an Mex67 in das Zytoplasma transportiert und vermutlich nicht wie unter normalen Wachstumsbedingungen von Dbp5-Gle1-IP 6 dissoziiert wird (Lund und Guthrie, 2005). Weitere Untersuchungen könnten klären, ob Mex67 eine Rolle in der Translation spielt und ob es am Translationskomplex auch nach der ersten Runde der Translation assoziiert bleibt. Auch bleibt die Frage offen, wie Mex67 vom Translationskomplex abgelöst wird und welche Faktoren dabei eine Rolle spielen. Durch das Ablösen von Mex67 von der mRNA unter normalen Bedingungen wird die Direktionalität des Transportes hergestellt. Wie die Direktionalität der Stress-spezifischen mRNAs verursacht wird, ist nun unklar.

\subsection{Der Promotor bestimmt, ob mRNAs qualitätskontrolliert werden}

Seit langem ist bekannt, dass es HSEs im Promotorbereich von Hitzeschockpromotoren gibt, die von dem Transkriptionsfaktor Hsf1 gebunden werden und für die spezifische Transkription von Hitzeschockproteine während Hitzestress verantwortlich sind (Sorger und Pelham, 1987). Außerdem konnte gezeigt werden, dass die HSEs für den Transport der Stress-spezifischen mRNAs in das Zytoplasma und deren Translation verantwortlich sind (Zid und O'Shea, 2014). In dieser Arbeit konnte weiterhin gezeigt werden, dass bei diesen Stress-spezifischen Transkripten keine mRNA-Qualitätskontrolle durchgeführt wird (Abbildung 35; Abbildung 36). Nun stellt sich die Frage, ob die mRNA-Qualitätskontrolle ebenfalls vom Hitzeschockpromotor abhängt und ob deshalb ein reguläres Transkript unter der Kontrolle eines Hitzeschockpromotor ohne mRNA-Qualitätskontrolle bei Stress 
exprimiert und exportiert wird. Um diese Fragestellung zu beantworten, wurde ein Konstrukt hergestellt, das einen Hitzeschockpromotor (mit HSEs) und einen ORF mit einem regulären Transkript enthält. Das Konstrukt enthält den Promotorbereich des HSP12 Genes und den ORF des Haushaltgenes CYCl (Abbildung 37). In FISH Experimenten wurde die Lokalisation der spezifischen mRNA in verschiedenen mutierten Hefestämmen untersucht (Abbildung 37; Abbildung 38). Dabei stellte sich heraus, dass die CYCl-mRNA unter der Kontrolle des HSP12-Promotors in das Zytoplasma exportiert wurde, wie die HSP12-mRNA unter Kontrolle des endogenen HSP12-Promotors (Abbildung 37). Im Vergleich dazu akkumulierte die $\mathrm{P}_{C Y C l}$-CYCl-mRNA im Zellkern. In den mRNA-exportdefekten Mutanten mex67-5 und mtr2-21 akkumulierten alle Konstrukte im Zellkern. Im Gegensatz dazu, kann man in dem Deletionsstamm von RRP6 und in der Mutante mtr4-G6777D keine Akkumulation der mRNAs, die unter Kontrolle des HSP12-Promotors stehen, feststellen. Es scheint, dass die CYC1-mRNA unter Kontrolle des HSP12-Promotors von der Zelle als Stress-spezifische mRNA erkannt wird und diese bei Hitzestress unkontrolliert in das Zytoplasma exportiert wird. Der Transport der Stress-spezifischen mRNAs in das Zytoplasma ist wahrscheinlich vom Promotor abhängig (Zid und O'Shea, 2014). Weiterhin wurde in dieser Arbeit deutlich, dass dieser Transport bei Stress, Mex67-Mtr2 spezifisch erfolgt und scheinbar nicht von der mRNA-Adaptor-vermittelten Qualitätskontrolle abhängig ist.

Zusammenfassend konnten in dieser Arbeit neue Hinweise für den Export der Stressspezifischen mRNAs gezeigt werden. So kann ein theoretisches Arbeitsmodell abgeleitet werden, bei dem die Aktivierung der Hitzeschockgene durch die Bindung des Hitzeschockfaktors Hsf1 an die HSEs im Promotorbereich erfolgt. Die Stress-spezifischen mRNAs werden nicht qualitätskontrolliert, was vorrangig vom Hitzeschockpromotor bestimmt wird. Neben dem THO-Komplex der bei der Beladung von Mex67-Mtr2 auf die Stress mRNAs beteiligt sein könnte, stellt sich die Frage ob der HitzeschockTranskriptionsfaktor Hsf1 ebenfalls einen Einfluss auf die Bindung von Mex67-Mtr2 an die Stress-mRNAs hat. Tatsächlich konnte bereits eine Stress-abhängige Interaktion von Hsf1 mit Mex67 detektiert werden (Zander et al., in Revision). Die Autoren konnten weiterhin durch „RNA sequencing“ Experimente eine erhöhte Bindung von Mex67 an die Hsf1Zieltranskripte im Vergleich zu Npl3 bei Hitzestress identifizieren. Es könnte zu einer schnellen und Adaptor-freien Bindung von Mex67-Mtr2 an die Stress-spezifischen mRNAs kommen, die zum umgehend Export der Transkripte in das Zytoplasma führt. 


\section{Literaturverzeichnis}

Ahn, S.H., Kim, M., and Buratowski, S. (2004). Phosphorylation of serine 2 within the RNA polymerase II C-terminal domain couples transcription and 3' end processing. Mol. Cell 13, 67-76.

Aibara, S., Valkov, E., Lamers, M.H., and Stewart, M. (2015). Domain organization within the nuclear export factor Mex67:Mtr2 generates an extended mRNA binding surface. Nucleic Acids Res. 43, 1927-1936.

Aitchison, J.D., Blobel, G., and Rout, M.P. (1996). Kap104p: a karyopherin involved in the nuclear transport of messenger RNA binding proteins. Science 274, 624-627.

Akerfelt, M., Morimoto, R.I., and Sistonen, L. (2010). Heat shock factors: integrators of cell stress, development and lifespan. Nat. Rev. Mol. Cell Biol. 11, 545-555.

Alcázar-Román, A.R., Tran, E.J., Guo, S., and Wente, S.R. (2006). Inositol hexakisphosphate and Gle1 activate the DEAD-box protein Dbp5 for nuclear mRNA export. Nat. Cell Biol. 8, 711-716.

Allmang, C., Kufel, J., Chanfreau, G., Mitchell, P., Petfalski, E., and Tollervey, D. (1999). Functions of the exosome in rRNA, snoRNA and snRNA synthesis. EMBO J. $18,5399-5410$.

Amberg, D.C., Goldstein, A.L., and Cole, C.N. (1992). Isolation and characterization of RAT1: An essential gene of Saccharomyces cerevisiae required for the efficient nucleocytoplasmic trafficking of mRNA. Genes Dev. 6, 1173-1189.

Anderson, J.T., and Wang, X. (2009). Nuclear RNA surveillance: no sign of substrates tailing off. Crit. Rev. Biochem. Mol. Biol. 44, 16-24.

Anderson, P., and Kedersha, N. (2006). RNA granules. J. Cell Biol. 172, 803-808.

Anderson, J.T., Wilson, S.M., Datar, K. V, and Swanson, M.S. (1993). NAB2: a yeast nuclear polyadenylated RNA-binding protein essential for cell viability. Mol. Cell. Biol. 13, 2730-2741.

Aravind, L., and Koonin, E. V (1999). DNA polymerase beta-like nucleotidyltransferase superfamily: identification of three new families, classification and evolutionary history. Nucleic Acids Res. 27, 1609-1618.

Arribere, J.A., Doudna, J.A., and Gilbert, W.V. (2011). Reconsidering Movement of Eukaryotic mRNAs between Polysomes and P Bodies. Mol. Cell 44, 745-758.

Babour, A., Dargemont, C., and Stutz, F. (2012). Ubiquitin and assembly of export competent mRNP. Biochim. Biophys. Acta 1819, 521-530.

Baejen, C., Torkler, P., Gressel, S., Essig, K., Söding, J., and Cramer, P. (2014). Transcriptome maps of mRNP biogenesis factors define pre-mRNA recognition. Mol Cell 55, 745-757.

Baierlein, C., Hackmann, A., Gross, T., Henker, L., Hinz, F., and Krebber, H. (2013). Monosome formation during translation initiation requires the serine/arginine-rich protein Npl3. Mol. Cell. Biol. 33, 4811-4823. 
Bailer, S.M., Siniossoglou, S., Podtelejnikov, A., Hellwig, A., Mann, M., and Hurt, E. (1998). Nup116p and Nup100p are interchangeable through a conserved motif which constitutes a docking site for the mRNA transport factor Gle2p. EMBO J. 17, 11071119.

Barillà, D., Lee, B. a, and Proudfoot, N.J. (2001). Cleavage/polyadenylation factor IA associates with the carboxyl-terminal domain of RNA polymerase II in Saccharomyces cerevisiae. Proc. Natl. Acad. Sci. U. S. A. 98, 445-450.

Barnes, C.A., MacKenzie, M.M., Johnston, G.C., and Singer, R.A. (1995). Efficient translation of an SSA1-derived heat-shock mRNA in yeast cells limited for cap-binding protein and eIF-4F. MGG Mol. Gen. Genet. 246, 619-627.

Barnwal, R.P., Lee, S.D., Moore, C., and Varani, G. (2012). Structural and biochemical analysis of the assembly and function of the yeast pre-mRNA 3' end processing complex CF I. Proc. Natl. Acad. Sci. U. S. A. 109, 21342-21347.

Baßler, J., Grandi, P., Gadal, O., Leßmann, T., Petfalski, E., Tollervey, D., Lechner, J., and Hurt, E. (2001). Identification of a 60S preribosomal particle that is closely linked to nuclear export. Mol. Cell 8, 517-529.

Bataille, A.R., Jeronimo, C., Jacques, P.-É., Laramée, L., Fortin, M.-È., Forest, A., Bergeron, M., Hanes, S.D., and Robert, F. (2012). A Universal RNA Polymerase II CTD Cycle Is Orchestrated by Complex Interplays between Kinase, Phosphatase, and Isomerase Enzymes along Genes. Mol. Cell 45, 158-170.

Batisse, J., Batisse, C., Budd, A., Böttcher, B., and Hurt, E. (2009). Purification of nuclear poly(A)-binding protein Nab2 reveals association with the yeast transcriptome and a messenger ribonucleoprotein core structure. J. Biol. Chem. 284, 34911-34917.

Bernstein, J., Patterson, D.N., Wilson, G.M., and Toth, E.A. (2008). Characterization of the essential activities of Saccharomyces cerevisiae Mtr4p, a 3'-->5' helicase partner of the nuclear exosome. J. Biol. Chem. 283, 4930-4942.

Birney, E., Kumar, S., and Krainer, A.R. (1993). Analysis of the RNA-recognition motif and RS and RGG domains: conservation in metazoan pre-mRNA splicing factors. Nucleic Acids Res. 21, 5803-5816.

Blobel, G., and Sabatini, D. (1971). Dissociation of mammalian polyribosomes into subunits by puromycin. Proc. Natl. Acad. Sci. U. S. A. 68, 390-394.

Boeke, J.D., Trueheart, J., Natsoulis, G., and Fink, G.R. (1987). [10] 5-Fluoroorotic acid as a selective agent in yeast molecular genetics. Methods Enzymol. 154, 164-175.

Bohnsack, M.T., Tollervey, D., and Granneman, S. (2012). Identification of RNA helicase target sites by UV cross-linking and analysis of cDNA. (Elsevier Inc.).

Bond, U. (1988). Heat shock but not other stress inducers leads to the disruption of a subset of snRNPs and inhibition of in vitro splicing in HeLa cells. 7, 3509-3518.

Bond, U. (2006). Stressed out! Effects of environmental stress on mRNA metabolism. FEMS Yeast Res. 6, 160-170.

Bonnet, A., and Palancade, B. (2014). Regulation of mRNA Trafficking by Nuclear Pore Complexes. Genes (Basel). 5, 767-791. 
Bonnet, A., Bretes, H., and Palancade, B. (2015). Nuclear pore components affect distinct stages of intron-containing gene expression. Nucleic Acids Res. 43, 4249-4261.

Bossie, M. a, DeHoratius, C., Barcelo, G., and Silver, P. (1992). A mutant nuclear protein with similarity to RNA binding proteins interferes with nuclear import in yeast. Mol. Biol. Cell 3, 875-893.

Bossier, P., Fitch, I.T., Boucherie, H., and Tuite, M.F. (1989). Structure and expression of a yeast gene encoding the small heat-shock protein Hsp26. Gene 78, 323-330.

Bracken, A.P., and Bond, U. (1999). Reassembly and protection of small nuclear ribonucleoprotein particles by heat shock proteins in yeast cells. 1586-1596.

Brengues, M., and Parker, R. (2007). Accumulation of Polyadenylated mRNA, Pab1p, eIF4E, and eIF4G with P-Bodies in Saccharomyces cerevisiae. Mol. Biol. Cell 18, 2592-2602.

Brengues, M., Teixeira, D., and Parker, R. (2005). Movement of Eukaryotic mRNAs Between Polysomes and Cytoplasmic Processing Bodies. Science (80-. ). 310, 486489.

Bretes, H., Rouviere, J.O., Leger, T., Oeffinger, M., Devaux, F., Doye, V., and Palancade, B. (2014). Sumoylation of the THO complex regulates the biogenesis of a subset of mRNPs. Nucleic Acids Res. 42, 5043-5058.

Brune, C., Munchel, S.E., Fischer, N., Podtelejnikov, A. V, and Weis, K. (2005). Yeast poly ( A ) -binding protein Pab1 shuttles between the nucleus and the cytoplasm and functions in mRNA export Yeast poly ( A ) -binding protein Pab1 shuttles between the nucleus and the cytoplasm and functions in mRNA export. Rna-a Publ. Rna Soc. 517531.

Buchan, J.R., and Parker, R. (2009). Eukaryotic Stress Granules: The Ins and Out of Translation. Mol. Cell 36.

Buchan, J.R., Muhlrad, D., and Parker, R. (2008). P bodies promote stress granule assembly in Saccharomyces cerevisiae. J. Cell Biol. 183, 441-455.

Bucheli, M.E., and Buratowski, S. (2005). Npl3 is an antagonist of mRNA 3' end formation by RNA polymerase II. EMBO J. 24, 2150-2160.

Bucheli, M.E., He, X., Kaplan, C.D., Moore, C.L., and Buratowski, S. (2007). Polyadenylation site choice in yeast is affected by competition between Npl3 and polyadenylation factor CFI. RNA 13, 1756-1764.

Carmody, S.R., and Wente, S.R. (2009). mRNA nuclear export at a glance. J. Cell Sci. 122, 1933-1937.

Carmody, S.R., Tran, E.J., Apponi, L.H., Corbett, A.H., and Wente, S.R. (2010). The Mitogen-Activated Protein Kinase Slt2 Regulates Nuclear Retention of Non-Heat Shock mRNAs during Heat Shock-Induced Stress. Mol. Cell. Biol. 30, 5168-5179.

Chapman, R.D., Heidemann, M., Hintermair, C., and Eick, D. (2008). Molecular evolution of the RNA polymerase II CTD. Trends Genet. 24, 289-296.

Cherkasov, V., Hofmann, S., Druffel-Augustin, S., Mogk, A., Tyedmers, J., Stoecklin, G., and Bukau, B. (2013). Coordination of Translational Control and Protein Homeostasis during Severe Heat Stress. Curr. Biol. 23, 2452-2462. 
Chien, A., Edgar, D.B., and Trela, J.M. (1976). Deoxyribonucleic acid polymerase from the extreme thermophile Thermus aquaticus. J. Bacteriol. 127, 1550-1557.

Christianson, T.W., Sikorski, R.S., Dante, M., Shero, J.H., and Hieter, P. (1992). Multifunctional yeast high-copy-number shuttle vectors. Gene 110, 119-122.

Craig, E. a, Kramer, J., Shilling, J., Werner-Washburne, M., Holmes, S., KosicSmithers, J., and Nicolet, C.M. (1989). SSC1, an essential member of the yeast HSP70 multigene family, encodes a mitochondrial protein. Mol. Cell. Biol. 9, 30003008.

Das, S., and Das, B. (2013). mRNA quality control pathways in Saccharomyces cerevisiae. J. Biosci. 38, 615-640.

Davis, C.A., Grate, L., Spingola, M., and Ares, M. (2000). Test of intron predictions reveals novel splice sites, alternatively spliced mRNAs and new introns in meiotically regulated genes of yeast. Nucleic Acids Res. 28, 1700-1706.

Decker, C.J., and Parker, R. (2012). P-bodies and stress granules: possible roles in the control of translation and mRNA degradation. Cold Spring Harb. Perspect. Biol. 4, 116.

Decker, C.J., Teixeira, D., and Parker, R. (2007). Edc3p and a glutamine/asparagine-rich domain of Lsm4p function in processing body assembly in Saccharomyces cerevisiae. J. Cell Biol. 179, 437-449.

Deka, P., Bucheli, M.E., Moore, C., Buratowski, S., and Varani, G. (2008). Structure of the yeast SR protein Npl3 and Interaction with mRNA 3'-end processing signals. J. Mol. Biol. 375, 136-150.

Dermody, J.L., Dreyfuss, J.M., Villén, J., Ogundipe, B., Gygi, S.P., Park, P.J., Ponticelli, A.S., Moore, C.L., Buratowski, S., and Bucheli, M.E. (2008). Unphosphorylated SR-like protein Npl3 stimulates RNA polymerase II elongation. PLoS One 3.

Dieppois, G., Iglesias, N., and Stutz, F. (2006). Cotranscriptional Recruitment to the mRNA Export Receptor Mex67p Contributes to Nuclear Pore Anchoring of Activated Genes. Mol. Cell. Biol. 26, 7858-7870.

Doma, M.K., and Parker, R. (2007). RNA quality control in eukaryotes. Cell 131, 660668.

Dunn, E.F., Hammell, C.M., Hodge, C. a, and Cole, C.N. (2005). Yeast poly(A)-binding protein, Pab1, and PAN, a poly(A) nuclease complex recruited by Pab1, connect mRNA biogenesis to export. Genes Dev. 19, 90-103.

Dziembowski, A., Lorentzen, E., Conti, E., and Séraphin, B. (2007). A single subunit, Dis3, is essentially responsible for yeast exosome core activity. Nat. Struct. Mol. Biol. $14,15-22$.

Ellisdon, A.M., Dimitrova, L., Hurt, E., and Stewart, M. (2012). Structural basis for the assembly and nucleic acid binding of the TREX-2 transcription-export complex. Nat. Struct. Mol. Biol. 19, 328-336.

Fasken, M.B., Stewart, M., and Corbett, A.H. (2008). Functional significance of the interaction between the mRNA-binding protein, Nab2, and the nuclear pore-associated protein, Mlp1, in mRNA export. J. Biol. Chem. 283, 27130-27143. 
Faza, M.B., Kemmler, S., Jimeno, S., González-Aguilera, C., Aguilera, A., Hurt, E., and Panse, V.G. (2009). Sem1 is a functional component of the nuclear pore complexassociated messenger RNA export machinery. J. Cell Biol. 184, 833-846.

Faza, M.B., Chang, Y., Occhipinti, L., Kemmler, S., and Panse, V.G. (2012). Role of Mex67-Mtr2 in the nuclear export of 40S pre-ribosomes. PLoS Genet. 8, e1002915.

Fischer, T., Sträßer, K., Rácz, A., Rodriguez-Navarro, S., Oppizzi, M., Ihrig, P., Lechner, J., and Hurt, E. (2002). The mRNA export machinery requires the novel Sac3p-Thp1p complex to dock at the nucleoplasmic entrance of the nuclear pores. EMBO J. 21, 5843-5852.

Fischer, T., Rodríguez-Navarro, S., Pereira, G., Rácz, A., Schiebel, E., and Hurt, E. (2004). Yeast centrin Cdc31 is linked to the nuclear mRNA export machinery. Nat. Cell Biol. 6, 840-848.

Flach, J., Bossie, M., Vogel, J., Corbett, a, Jinks, T., Willins, D. a, and Silver, P. a (1994). A yeast RNA-binding protein shuttles between the nucleus and the cytoplasm. Mol. Cell. Biol. 14, 8399-8407.

Floch, A.G., Palancade, B., and Doye, V. (2014). Fifty years of nuclear pores and nucleocytoplasmic transport studies: multiple tools revealing complex rules. CHAPTER 1.

Fornerod, M., Ohno, M., Yoshida, M., and Mattaj, I.W. (1997). CRM1 Is an Export Receptor for Leucine-Rich Nuclear Export Signals. Cell 90, 1051-1060.

Fox, M.J., and Mosley, A.L. (2015). Rrp6: Integrated roles in nuclear RNA metabolism and transcription termination. Wiley Interdiscip. Rev. RNA 7, n/a - n/a.

Fredrickson, E.K., Gallagher, P.S., Candadai, S.V.C., and Gardner, R.G. (2013). Substrate recognition in nuclear protein quality control degradation is governed by exposed hydrophobicity that correlates with aggregation and insolubility. J. Biol. Chem. 288, 6130-6139.

Frey, S., Pool, M., and Seedorf, M. (2001). Scp160p, an RNA-binding, Polysomeassociated Protein, Localizes to the Endoplasmic Reticulum of Saccharomyces cerevisiae in a Microtubule-dependent Manner. J. Biol. Chem. 276, 15905-15912.

Gadal, O., Strauss, D., Kessl, J., Trumpower, B., Tollervey, D., and Hurt, E. (2001). Nuclear export of 60s ribosomal subunits depends on Xpolp and requires a nuclear export sequence-containing factor, Nmd3p, that associates with the large subunit protein Rpl10p. Mol. Cell. Biol. 21, 3405-3415.

Galy, V., Gadal, O., Fromont-Racine, M., Romano, A., Jacquier, A., and Nehrbass, U. (2004). Nuclear Retention of Unspliced mRNAs in Yeast Is Mediated by Perinuclear Mlp1. Cell 116, 63-73.

Garcia, I., and Uhlenbeck, O.C. (2008). Differential RNA-dependent ATPase activities of four rRNA processing yeast DEAD-box proteins. Biochemistry 47, 12562-12573.

Garfin, D.E. (1990). One-dimensional gel electrophoresis. Methods Enzymol. 182, 425441.

Gautschi, M., Mun, A., Ross, S., and Rospert, S. (2002). A functional chaperone triad on the yeast ribosome. Proc. Natl. Acad. Sci. U. S. A. 99, 4209-4214. 
Gelin-Licht, R., Paliwal, S., Conlon, P., Levchenko, A., and Gerst, J.E. (2012). Scp160Dependent mRNA Trafficking Mediates Pheromone Gradient Sensing and Chemotropism in Yeast. Cell Rep. 1, 483-494.

Gerstel, B., Tuite, M.F., and McCarthy, J.E.G. (1992). The effects of 5'-capping, 3'polyadenylation and leader composition upon the translation and stability of mRNA in a cell-free extract derived from the yeast Saccharomyces cerevisiae. Mol. Microbiol. 6, 2339-2348.

Gewartowski, K., Cuéllar, J., Dziembowski, A., and Valpuesta, J.M. (2012). The yeast THO complex forms a 5-subunit assembly that directly interacts with active chromatin. Bioarchitecture 2, 134-137.

Ghaemmaghami, S., Huh, W.-K., Bower, K., Howson, R.W., Belle, A., Dephoure, N., O'Shea, E.K., and Weissman, J.S. (2003). Global analysis of protein expression in yeast. Nature 425, 737-741.

Gibson, D.G. (2009). Synthesis of DNA fragments in yeast by one-step assembly of overlapping oligonucleotides. Nucleic Acids Res. 37, 6984-6990.

Gibson, D.G. (2011). Gene and genome construction in yeast. Curr. Protoc. Mol. Biol.

Gibson, D.G., Young, L., Chuang, R.-Y., Venter, J.C., Hutchison, C.A., and Smith, H.O. (2009). Enzymatic assembly of DNA molecules up to several hundred kilobases. Nat. Methods 6, 343-345.

Gietz, D., St Jean, A., Woods, R.A., and Schiestl, R.H. (1992). Improved method for high efficiency transformation of intact yeast cells. Nucl Acid Res 20, 1425.

Gilbert, W., and Guthrie, C. (2004). The Glc7p Nuclear Phosphatase Promotes mRNA Export by Facilitating Association of Mex67p with mRNA. Mol. Cell 13, 201-212.

Gilbert, W., Siebel, C.W., and Guthrie, C. (2001). Phosphorylation by Sky1p promotes Npl3p shuttling and mRNA dissociation. RNA 7, 302-313.

González, C.I., Ruiz-Echevarría, M.J., Vasudevan, S., Henry, M.F., and Peltz, S.W. (2000). The Yeast hnRNP-like Protein Hrp1/Nab4 Marks a Transcript for NonsenseMediated mRNA Decay. Mol. Cell 5, 489-499.

González-Aguilera, C., Tous, C., Gómez-González, B., Huertas, P., Luna, R., and Aguilera, A. (2008). The THP1-SAC3-SUS1-CDC31 complex works in transcription elongation-mRNA export preventing RNA-mediated genome instability. Mol. Biol. Cell 19, 4310-4318.

Görnemann, J., Kotovic, K.M., Hujer, K., and Neugebauer, K.M. (2005). Cotranscriptional Spliceosome Assembly Occurs in a Stepwise Fashion and Requires the Cap Binding Complex. Mol. Cell 19, 53-63.

Görner, W., Durchschlag, E., Martinez-Pastor, M.T., Estruch, F., Ammerer, G., Hamilton, B., Ruis, H., and Schüller, C. (1998). Nuclear localization of the C2H2 zinc finger protein Msn2p is regulated by stress and protein kinase A activity. Genes Dev. 12, 586-597.

Gorsch, L.C., Dockendorff, T.C., and Cole, C.N. (1995). A conditional allele of the novel repeat-containing yeast nucleoporin RAT7/NUP159 causes both rapid cessation of mRNA export and reversible clustering of nuclear pore complexes. J. Cell Biol. 129, 939-955. 
Grant, R.P., Hurt, E., Neuhaus, D., and Stewart, M. (2002). Structure of the C-terminal FG-nucleoporin binding domain of Tap/NXF1. Nat. Struct. Biol. 9, 247-251.

Grant, R.P., Marshall, N.J., Yang, J.C., Fasken, M.B., Kelly, S.M., Harreman, M.T., Neuhaus, D., Corbett, A.H., and Stewart, M. (2008). Structure of the N-Terminal Mlp1-Binding Domain of the Saccharomyces cerevisiae mRNA-Binding Protein, Nab2. J. Mol. Biol. 376, 1048-1059.

Green, D.M., Johnson, C.P., Hagan, H., and Corbett, A.H. (2003). The C-terminal domain of myosin-like protein 1 (Mlp1p) is a docking site for heterogeneous nuclear ribonucleoproteins that are required for mRNA export. Proc. Natl. Acad. Sci. U. S. A. 100, 1010-1015.

Griffioen, G., Branduardi, P., Ballarini, A., Anghileri, P., Norbeck, J., Baroni, M.D., and Ruis, H. (2001). Nucleocytoplasmic Distribution of Budding Yeast Protein Kinase A Regulatory Subunit Bcy1 Requires Zds1 and Is Regulated by Yak1-Dependent Phosphorylation of Its Targeting Domain. Mol. Cell. Biol. 21, 511-523.

Gross, T., Siepmann, A., Sturm, D., Windgassen, M., Scarcelli, J.J., Seedorf, M., Cole, C.N., and Krebber, H. (2007). The DEAD-box RNA helicase Dbp5 functions in translation termination. Science 315, 646-649.

Grousl, T., Ivanov, P., Frýdlová, I., Vasicová, P., Janda, F., Vojtová, J., Malínská, K., Malcová, I., Nováková, L., Janosková, D., et al. (2009). Robust heat shock induces eIF2alpha-phosphorylation-independent assembly of stress granules containing eIF3 and $40 \mathrm{~S}$ ribosomal subunits in budding yeast, Saccharomyces cerevisiae. J. Cell Sci. 122, 2078-2088.

Grousl, T., Ivanov, P., Malcova, I., Pompach, P., Frydlova, I., Slaba, R., Senohrabkova, L., Novakova, L., and Hasek, J. (2013). Heat shock-induced accumulation of translation elongation and termination factors precedes assembly of stress granules in S. cerevisiae. PLoS One 8, e57083.

Guo, M., Aston, C., Burchett, S.A., Dyke, C., Fields, S., Rajarao, S.J.R., Uetz, P., Wang, Y., Young, K., and Dohlman, H.G. (2003). The Yeast G Protein alpha Subunit Gpa1 Transmits a Signal through an RNA Binding Effector Protein Scp160. Mol. Cell 12, $517-524$.

Gwizdek, C., Iglesias, N., Rodriguez, M.S., Ossareh-Nazari, B., Hobeika, M., Divita, G., Stutz, F., and Dargemont, C. (2006). Ubiquitin-associated domain of Mex67 synchronizes recruitment of the mRNA export machinery with transcription. Proc. Natl. Acad. Sci. U. S. A. 103, 16376-16381.

Hacker, S., and Krebber, H. (2004). Differential Export Requirements for Shuttling Serine/Arginine-type mRNA-binding Proteins. J. Biol. Chem. 279, 5049-5052.

Hackmann, A., and Krebber, H. (2014). Fungal RNA Biology (Cham: Springer International Publishing).

Hackmann, A., Gross, T., Baierlein, C., and Krebber, H. (2011). The mRNA export factor Npl3 mediates the nuclear export of large ribosomal subunits. EMBO Rep. 12, 1024-1031.

Hackmann, A., Wu, H., Schneider, U.-M., Meyer, K., Jung, K., and Krebber, H. (2014). Quality control of spliced mRNAs requires the shuttling SR proteins Gbp2 and Hrb1. Nat. Commun. 5, 3123. 
Hahn, J.-S., and Thiele, D.J. (2004). Activation of the Saccharomyces cerevisiae heat shock transcription factor under glucose starvation conditions by Snf1 protein kinase. J. Biol. Chem. 279, 5169-5176.

Hamill, S., Wolin, S.L., and Reinisch, K.M. (2010). Structure and function of the polymerase core of TRAMP, a RNA surveillance complex. Proc. Natl. Acad. Sci. 107, $15045-15050$.

Harper, S., and Speicher, D.W. (2008). Expression and purification of GST fusion proteins. Curr. Protoc. Protein Sci.

Hashikawa, N., Mizukami, Y., Imazu, H., and Sakurai, H. (2006). Mutated Yeast Heat Shock Transcription Factor Activates Transcription Independently of Hyperphosphorylation. J. Biol. Chem. 281, 3936-3942.

Haslbeck, M., Miess, A., Stromer, T., Walter, S., and Buchner, J. (2005). Disassembling protein aggregates in the yeast cytosol: The cooperation of HSP26 with SSA1 and HSP104. J. Biol. Chem. 280, 23861-23868.

Hector, R.E., Nykamp, K.R., Dheur, S., Anderson, J.T., Non, P.J., Urbinati, C.R., Wilson, S.M., Minvielle-Sebastia, L., and Swanson, M.S. (2002). Dual requirement for yeast hnRNP Nab2p in mRNA poly(A) tail length control and nuclear export. EMBO J. 21, 1800-1810.

Heidemann, M., Hintermair, C., Voß, K., and Eick, D. (2013). Dynamic phosphorylation patterns of RNA polymerase II CTD during transcription. Biochim. Biophys. Acta $1829,55-62$.

Hieronymus, H., and Silver, P.A. (2003). Genome-wide analysis of RNA-protein interactions illustrates specificity of the mRNA export machinery. Nat. Genet. 33, 155161.

Hilleren, P., McCarthy, T., Rosbash, M., Parker, R., and Jensen, T.H. (2001). Quality control of mRNA 3 '-end processing is linked to the nuclear exosome. Nature 413, 538542 .

Ho, J.H., Kallstrom, G., and Johnson, A.W. (2000). Nmd3p is a Crm1p-dependent adapter protein for nuclear export of the large ribosomal subunit. J. Cell Biol. 151, 1057-1066.

Hobeika, M., Brockmann, C., Iglesias, N., Gwizdek, C., Neuhaus, D., Stutz, F., Stewart, M., Gilles, D., and Dargemont, C. (2007). Coordination of Hpr1 and Ubiquitin Binding by the UBA Domain of the mRNA Export Factor Mex67. Mol. Biol. Cell 18, 2561-2568.

Hobeika, M., Brockmann, C., Gruessing, F., Neuhaus, D., Divita, G., Stewart, M., and Dargemont, C. (2009). Structural Requirements for the Ubiquitin-associated Domain of the mRNA Export Factor Mex67 to Bind Its Specific Targets, the Transcription Elongation THO Complex Component Hpr1 and Nucleoporin FXFG Repeats. J. Biol. Chem. 284, 17575-17583.

van Hoof, A., Lennertz, P., and Parker, R. (2000). Yeast exosome mutants accumulate 3 '-extended polyadenylated forms of U4 small nuclear RNA and small nucleolar RNAs. Mol. Cell. Biol. 20, 441-452.

Houseley, J., and Tollervey, D. (2009). The many pathways of RNA degradation. Cell 136, 763-776. 
Houseley, J., LaCava, J., and Tollervey, D. (2006). RNA-quality control by the exosome. Nat. Rev. Mol. Cell Biol. 7, 529-539.

Hoyle, N.P., and Ashe, M.P. (2008). Subcellular localization of mRNA and factors involved in translation initiation. Biochem. Soc. Trans. 36, 648-652.

Hoyle, N.P., Castelli, L.M., Campbell, S.G., Holmes, L.E. a, and Ashe, M.P. (2007). Stress-dependent relocalization of translationally primed mRNPs to cytoplasmic granules that are kinetically and spatially distinct from P-bodies. J. Cell Biol. 179, 6574.

Huang, P., Gautschi, M., Walter, W., Rospert, S., and Craig, E.A. (2005). The Hsp70 Ssz1 modulates the function of the ribosome-associated J-protein Zuo1. Nat. Struct. Mol. Biol. 12, 497-504.

Huertas, P., and Aguilera, A. (2003). Cotranscriptionally formed DNA:RNA hybrids mediate transcription elongation impairment and transcription-associated recombination. Mol. Cell 12, 711-721.

Hundley, H., Eisenman, H., Walter, W., Evans, T., Hotokezaka, Y., Wiedmann, M., and Craig, E. (2002). The in vivo function of the ribosome-associated Hsp70, Ssz1, does not require its putative peptide-binding domain. Proc. Natl. Acad. Sci. U. S. A. 99, 4203-4208.

Hurt, E., Sträßer, K., Segref, A., Bailer, S., Schlaich, N., Presutti, C., Tollervey, D., Jansen, R., and Stra, K. (2000). Mex67p Mediates Nuclear Export of a Variety of RNA Polymerase II Transcripts. J. Biol. Chem. 275, 8361-8368.

Hurt, E., Luo, M.-J., Röther, S., Reed, R., and Strässer, K. (2004). Cotranscriptional recruitment of the serine-arginine-rich (SR)-like proteins Gbp2 and Hrb1 to nascent mRNA via the TREX complex. Proc. Natl. Acad. Sci. U. S. A. 101, 1858-1862.

Iglesias, N., Tutucci, E., Gwizdek, C., Vinciguerra, P., Von Dach, E., Corbett, A.H., Dargemont, C., and Stutz, F. (2010). Ubiquitin-mediated mRNP dynamics and surveillance prior to budding yeast mRNA export. Genes Dev. 24, 1927-1938.

Inoue, H., Nojima, H., and Okayama, H. (1990). High efficiency transformation of Escherichia coli with plasmids. Gene 96, 23-28.

Izaurralde, E. (2004). Directing mRNA export. Nat. Struct. Mol. Biol. 11, 210-212.

Izawa, S., Takemura, R., and Inoue, Y. (2004). Gle2p is essential to induce adaptation of the export of bulk poly(A) + mRNA to heat shock in Saccharomyces cerevisiae. J. Biol. Chem. 279, 35469-35478.

Jacquet, M., Renault, G., Lallet, S., De Mey, J., and Goldbeter, A. (2003). Oscillatory nucleocytoplasmic shuttling of the general stress response transcriptional activators Msn2 and Msn4 in Saccharomyces cerevisiae. J. Cell Biol. 161, 497-505.

Jani, D., Lutz, S., Marshall, N.J., Fischer, T., Köhler, A., Ellisdon, A.M., Hurt, E., Stewart, M., Andrew, M., Hurt, E., et al. (2009). Sus1, Cdc31, and the Sac3 CID Region Form a Conserved Interaction Platform that Promotes Nuclear Pore Association and mRNA Export. Mol. Cell 33, 727-737.

Jensen, T.H., Patricio, K., Mccarthy, T., and Rosbash, M. (2001). A Block to mRNA Nuclear Export in S . cerevisiae Leads to Hyperadenylation of Transcripts that Accumulate at the Site of Transcription. 7, 887-898. 
Jia, H., Wang, X., Liu, F., Guenther, U.-P., Srinivasan, S., Anderson, J.T., and Jankowsky, E. (2011). The RNA Helicase Mtr4p Modulates Polyadenylation in the TRAMP Complex. Cell 145, 890-901.

Jimeno, S., Rondón, A. G., Luna, R., and Aguilera, A. (2002). The yeast THO complex and mRNA export factors link RNA metabolism with transcription and genome instability. EMBO J. 21, 3526-3535.

Jinek, M., Coyle, S.M., and Doudna, J.A. (2011). Coupled 5' Nucleotide Recognition and Processivity in Xrn1-Mediated mRNA Decay. Mol. Cell 41, 600-608.

Jurica, M.S., and Moore, M.J. (2003). Pre-mRNA splicing: awash in a sea of proteins. Mol. Cell 12, 5-14.

Katahira, J. (2011). mRNA export and the TREX complex. Biochim. Biophys. Acta - Gene Regul. Mech. 1819, 507-513.

Kato, K., Yamamoto, Y., and Izawa, S. (2011). Severe ethanol stress induces assembly of stress granules in Saccharomyces cerevisiae. Yeast 28, 339-347.

Kelly, S.M., Pabit, S. a, Kitchen, C.M., Guo, P., Marfatia, K. a, Murphy, T.J., Corbett, A.H., and Berland, K.M. (2007). Recognition of polyadenosine RNA by zinc finger proteins. Proc. Natl. Acad. Sci. U. S. A. 104, 12306-12311.

Kemp, D.J., Smith, D.B., Foote, S.J., Samaras, N., and Peterson, M.G. (1989). Colorimetric detection of specific DNA segments amplified by polymerase chain reactions. Proc. Natl. Acad. Sci. U. S. A. 86, 2423-2427.

Kendirgi, F., Rexer, D.J., Alca, A.R., Onishko, H.M., and Wente, S.R. (2005). Interaction between the Shuttling mRNA Export Factor Gle1 and the Nucleoporin hCG1 : A Conserved Mechanism in the Export of Hsp70 mRNA. 16, 4304-4315.

Kessler, M.M., Henry, M.F., Shen, E., Zhao, J., Gross, S., Silver, P. a, and Moore, C.L. (1997). Hrp1, a sequence-specific RNA-binding protein that shuttles between the nucleus and the cytoplasm, is required for mRNA 3'-end formation in yeast. Genes Dev. 11, 2545-2556.

Köhler, A., and Hurt, E. (2007). Exporting RNA from the nucleus to the cytoplasm. Nat. Rev. Mol. Cell Biol. 8, 761-773.

Köhler, A., Schneider, M., Cabal, G.G., Nehrbass, U., and Hurt, E. (2008). Yeast Ataxin-7 links histone deubiquitination with gene gating and mRNA export. Nat. Cell Biol. 10, 707-715.

Kong, K.-Y.E., Tang, H.-M. V., Pan, K., Huang, Z., Lee, T.-H.J., Hinnebusch, A. G., Jin, D.-Y., and Wong, C.-M. (2013). Cotranscriptional recruitment of yeast TRAMP complex to intronic sequences promotes optimal pre-mRNA splicing. Nucleic Acids Res. 42, 643-660.

Krebber, H., Taura, T., Lee, M.S., and Silver, P.A. (1999). Uncoupling of hnRNP Npl3p from mRNAs during the stress-induced block in mRNA export. Genes Dev. 13, 19942004.

Kress, T.L., Krogan, N.J., and Guthrie, C. (2008). A Single SR-like Protein, Npl3, Promotes Pre-mRNA Splicing in Budding Yeast. Mol. Cell 32, 727-734. 
LaCava, J., Houseley, J., Saveanu, C., Petfalski, E., Thompson, E., Jacquier, A., and Tollervey, D. (2005). RNA degradation by the exosome is promoted by a nuclear polyadenylation complex. Cell 121, 713-724.

Laemmli, U.K. (1970). Cleavage of structural proteins during the assembly of the head of bacteriophage T4. Nature 227, 680-685.

Lallet, S., Garreau, H., Poisier, C., Boy-Marcotte, E., and Jacquet, M. (2004). Heat shock-induced degradation of Msn2p, a Saccharomyces cerevisiae transcription factor, occurs in the nucleus. Mol. Genet. Genomics 272, 353-362.

Lang, B.D., and Fridovich-Keil, J.L. (2000). Scp160p, a multiple KH-domain protein, is a component of mRNP complexes in yeast. Nucleic Acids Res. 28, 1576-1584.

Larimer, F.W., and Stevens, A. (1990). Disruption of the gene XRN1, coding for a 5' $\rightarrow 3^{\prime}$ exoribonuclease, restricts yeast cell growth. Gene 95, 85-90.

Lee, M.S., Henry, M., and Silver, P. a (1996). A protein that shuttles between the nucleus and the cytoplasm is an important mediator of RNA export. Genes Dev 10, 1233-1246.

Lee, P., Cho, B.-R., Joo, H.-S., and Hahn, J.-S. (2008). Yeast Yak1 kinase, a bridge between PKA and stress-responsive transcription factors, Hsf1 and Msn2/Msn4. Mol. Microbiol. 70, 882-895.

Lei, E.P., Krebber, H., and Silver, P.A. (2001). Messenger RNAs are recruited for nuclear export during transcription. Genes Dev. 15, 1771-1782.

Lenssen, E., James, N., Pedruzzi, I., Dubouloz, F., Cameroni, E., Bisig, R., Maillet, L., Werner, M., Roosen, J., Petrovic, K., et al. (2004). The Ccr4-Not Complex Independently Controls both Msn2-Dependent Transcriptional Activation--via a Newly Identified Glc7/Bud14 Type I Protein Phosphatase Module--and TFIID Promoter Distribution. Mol. Cell. Biol. 25, 488-498.

Lewis, A., Felberbaum, R., and Hochstrasser, M. (2007). A nuclear envelope protein linking nuclear pore basket assembly, SUMO protease regulation, and mRNA surveillance. J. Cell Biol. 178, 813-827.

Li, A.M., Watson, A., and Fridovich-Keil, J.L. (2003). Scp160p associates with specific mRNAs in yeast. Nucleic Acids Res. 31, 1830-1837.

Libri, D., Dower, K., Boulay, J., Rosbash, M., Jensen, T.H., and Thomsen, R. (2002). Interactions between mRNA Export Commitment , $3^{\prime}$-End Quality Control , and Nuclear Degradation Interactions between mRNA Export Commitment , 3J-End Quality Control, and Nuclear Degradation.

Lidschreiber, M., Leike, K., and Cramer, P. (2013). Cap Completion and C-Terminal Repeat Domain Kinase Recruitment Underlie the Initiation-Elongation Transition of RNA Polymerase II. Mol. Cell. Biol. 33, 3805-3816.

Liu, X., and Thiele, D.J. (1996). Oxidative stress induces heat shock factor phosphorylation and HSF-dependent activation of yeast metallothionein gene transcription. 592-603.

Liu, Q., Greimann, J.C., and Lima, C.D. (2006). Reconstitution, Activities, and Structure of the Eukaryotic RNA Exosome. Cell 127, 1223-1237.

Lund, M.K., and Guthrie, C. (2005). The DEAD-box protein Dbp5p is required to dissociate Mex67p from exported mRNPs at the nuclear rim. Mol. Cell 20, 645-651. 
Lundberg, K.S., Shoemaker, D.D., Adams, M.W.W., Short, J.M., Sorge, J.A., and Mathur, E.J. (1991). High-fidelity amplification using a thermostable DNA polymerase isolated from Pyrococcus furiosus. Gene 108, 1-6.

Lykke-Andersen, S., Tomecki, R., Jensen, T.H., and Dziembowski, A. (2011). The eukaryotic RNA exosome: same scaffold but variable catalytic subunits. RNA Biol. 8 , 61-66.

Marfatia, K.A., Crafton, E.B., Green, D.M., and Corbett, A.H. (2003). Domain Analysis of the Saccharomyces cerevisiae Heterogeneous Nuclear Ribonucleoprotein, Nab2p. J. Biol. Chem. 278, 6731-6740.

Martínez-Lumbreras, S., Taverniti, V., Zorrilla, S., Séraphin, B., and PérezCañadillas, J.M. (2015). Gbp2 interacts with THO/TREX through a novel type of RRM domain. Nucleic Acids Res. gkv1303.

Martínez-Pastor, M.T., Marchler, G., Schüller, C., Marchler-Bauer, A., Ruis, H., and Estruch, F. (1996). The Saccharomyces cerevisiae zinc finger proteins Msn2p and Msn4p are required for transcriptional induction through the stress response element (STRE). EMBO J. 15, 2227-2235.

Mašek, T., Valášek, L., and Pospíšek, M. (2011). Polysome analysis and RNA purification from sucrose gradients. Methods Mol. Biol. 703, 293-309.

Mayer, A., Heidemann, M., Lidschreiber, M., Schreieck, A., Sun, M., Hintermair, C., Kremmer, E., Eick, D., and Cramer, P. (2012). CTD tyrosine phosphorylation impairs termination factor recruitment to RNA polymerase II. Science 336, 1723-1725.

Mayordomo, I., Estruch, F., and Sanz, P. (2002). Convergence of the target of rapamycin and the Snf1 protein kinase pathways in the regulation of the subcellular localization of Msn2, a transcriptional activator of STRE (Stress Response Element)-regulated genes. J. Biol. Chem. 277, 35650-35656.

McBride, A. E., Cook, J.T., Stemmler, E. a., Rutledge, K.L., McGrath, K. a., and Rubens, J. a. (2005). Arginine Methylation of Yeast mRNA-binding Protein Npl3 Directly Affects Its Function, Nuclear Export, and Intranuclear Protein Interactions. J. Biol. Chem. 280, 30888-30898.

Milligan, L., Torchet, C., Allmang, C., Shipman, T., and Tollervey, D. (2005). A nuclear surveillance pathway for mRNAs with defective polyadenylation. Mol. Cell. Biol. 25, 9996-10004.

Mitchell, P., Petfalski, E., Shevchenko, A., Mann, M., and Tollervey, D. (1997). The Exosome: A Conserved Eukaryotic RNA Processing Complex Containing Multiple 3'$>5^{\prime}$ Exoribonucleases. Cell 91, 457-466.

Mitchell, S.F., Jain, S., She, M., and Parker, R. (2013). Global analysis of yeast mRNPs. Nat. Struct. Mol. Biol. 20, 127-133.

Morano, K. a., Grant, C.M., and Moye-Rowley, W.S. (2012). The Response to Heat Shock and Oxidative Stress in Saccharomyces cerevisiae. Genetics 190, 1157-1195.

Murphy, R., Watkins, J.L., and Wente, S.R. (1996). GLE2, a Saccharomyces cerevisiae homologue of the Schizosaccharomyces pombe export factor RAE1, is required for nuclear pore complex structure and function. Mol. Biol. Cell 7, 1921-1937. 
Nanduri, J., and Tartakoff, A.M. (2001). Perturbation of the nucleus: a novel Hog1pindependent, Pkc1p-dependent consequence of hypertonic shock in yeast. Mol Biol Cell 12, 1835-1841.

Neumann, B., Wu, H., Hackmann, A., and Krebber, H. (2016). Nuclear Export of PreRibosomal Subunits Requires Dbp5, but Not as an RNA-Helicase as for mRNA Export. PLoS One 11, e0149571.

Neville, M., and Rosbash, M. (1999). The NES-Crm1p export pathway is not a major mRNA export route in Saccharomyces cerevisiae. EMBO J. 18, 3746-3756.

Niepel, M., Molloy, K.R., Williams, R., Farr, J.C., Meinema, A. C., Vecchietti, N., Cristea, I.M., Chait, B.T., Rout, M.P., and Strambio-De-Castillia, C. (2013). The nuclear basket proteins Mlp1p and Mlp2p are part of a dynamic interactome including Esc1p and the proteasome. Mol. Biol. Cell 24, 3920-3938.

Niño, C. a, Hérissant, L., Babour, A., and Dargemont, C. (2013). mRNA Nuclear Export in Yeast. Chem. Rev.

Palancade, B., Michela, Z., Loeillet, S., Nicolas, A., and Doye, V. (2005). Pml39, a Novel Protein of the Nuclear Periphery Required for Nuclear Retention of Improper Messenger Ribonucleoparticles. Mol. Biol. Cell 16, 5258-5268.

Paolo, S.S., Vanacova, S., Schenk, L., Scherrer, T., Blank, D., Keller, W., and Gerber, A.P. (2009). Distinct Roles of Non-Canonical Poly(A) Polymerases in RNA Metabolism. PLoS Genet. 5, e1000555.

Parker, R., and Sheth, U. (2007). P Bodies and the Control of mRNA Translation and Degradation. Mol. Cell 25, 635-646.

Qu, X., Lykke-Andersen, S., Nasser, T., Saguez, C., Bertrand, E., Jensen, T.H., and Moore, C. (2009). Assembly of an export-competent mRNP is needed for efficient release of the 3'-end processing complex after polyadenylation. Mol. Cell. Biol. 29, 5327-5338.

Rakwalska, M., and Rospert, S. (2004). The ribosome-bound chaperones RAC and $\mathrm{Ssb} 1 / 2 \mathrm{p}$ are required for accurate translation in Saccharomyces cerevisiae. Mol. Cell. Biol. 24, 9186-9197.

Reed, R., and Hurt, E. (2002). A conserved mRNA export machinery coupled to premRNA splicing. Cell 108, 523-531.

Regot, S., de Nadal, E., Rodríguez-Navarro, S., González-Novo, A., Pérez-Fernandez, J., Gadal, O., Seisenbacher, G., Ammerer, G., and Posas, F. (2013). The Hog1 stress-activated protein kinase targets nucleoporins to control mRNA export upon stress. J. Biol. Chem. 288, 17384-17398.

Rhoads, R.E., and Lamphear, B.J. (1995). Cap-independent translation of heat shock messenger RNAs. Curr. Top. Microbiol. Immunol. 203, 131-153.

Rodríguez-Navarro, S., Fischer, T., Luo, M.J., Antúnez, O., Brettschneider, S., Lechner, J., Pérez-Ortín, J.E., Reed, R., and Hurt, E. (2004). Sus1, a Functional Component of the SAGA Histone Acetylase Complex and the Nuclear Pore-Associated mRNA Export Machinery. Cell 116, 75-86. 
Rollenhagen, C., Hodge, C., and Cole, C.N. (2007). Following temperature stress, export of heat shock mRNA occurs efficiently in cells with mutations in genes normally important for mRNA export. Eukaryot. Cell 6, 505-513.

Rondón, A.G., Jimeno, S., García-Rubio, M., and Aguilera, A. (2003). Molecular Evidence That the Eukaryotic THO/TREX Complex Is Required for Efficient Transcription Elongation. J. Biol. Chem. 278, 39037-39043.

Rose, M.D., Winston, F., and Hieter, P. (1990). Methods in Yeast Genetics, A Laboratory Course Manual. Cold Spring Harb. Lab. Press. New York.

Rougemaille, M., Gudipati, R.K., Olesen, J.R., Thomsen, R., Seraphin, B., Libri, D., and Jensen, T.H. (2007). Dissecting mechanisms of nuclear mRNA surveillance in THO/sub2 complex mutants. EMBO J. 26, 2317-2326.

Saavedra, C., Tung, K.S., Amberg, D.C., Hopper, A.K., and Cole, C.N. (1996). Regulation of mRNA export in response to stress in Saccharomyces cerevisiae. Genes Dev. 10, 1608-1620.

Saavedra, C., Hammell, C.M., Heath, C. V., and Cole, C.N. (1997). Yeast heat shock mRNAs are exported through a distinct pathway defined by Rip1p. Genes Dev. 11, 2845-2856.

Sachs, A.B., and Davis, R.W. (1989). The poly(A) binding protein is required for poly(A) shortening and 60S ribosomal subunit-dependent translation initiation. Cell 58, 857867.

Sachs, A.B., Davis, R.W., and Kornberg, R.D. (1987). A single domain of yeast poly(A)binding protein is necessary and sufficient for RNA binding and cell viability. Mol. Cell. Biol. 7, 3268-3276.

Saguez, C., Schmid, M., Olesen, J.R., Ghazy, M.A.E.-H., Qu, X., Poulsen, M.B., Nasser, T., Moore, C., and Jensen, T.H. (2008). Nuclear mRNA Surveillance in THO/sub2 Mutants Is Triggered by Inefficient Polyadenylation. Mol. Cell 31, 91-103.

Saiki, R.K., Gelfand, D.H., Stoffel, S., Scharf, S.J., Higuchi, R., Horn, G.T., Mullis, K.B., and Erlich, H.A. (1988). Primer-directed enzymatic amplification of DNA with a thermostable DNA polymerase. Science 239, 487-491.

Sambrook, J., Fritsch, E.F., and Maniatis, T. (1989). Molecular Cloning: A Laboratory Manual. Cold Spring Harbor laboratory press.

Santos-Pereira, J.M., Herrero, A.B., Moreno, S., and Aguilera, A. (2014). Npl3, a new link between RNA-binding proteins and the maintenance of genome integrity. Cell Cycle 13, 1524-1529.

Santos-Rosa, H., Moreno, H., Simos, G., Segref, A., Fahrenkrog, B., and Panté, N. (1998). Nuclear mRNA Export Requires Complex Formation between Mex67p and Mtr2p at the Nuclear Pores Nuclear mRNA Export Requires Complex Formation between Mex67p and Mtr2p at the Nuclear Pores.

Schmid, M., and Jensen, T.H. (2013). Transcription-associated quality control of mRNP. Biochim. Biophys. Acta 1829, 158-168. 
Schmid, M., Poulsen, M.B., Olszewski, P., Pelechano, V., Saguez, C., Gupta, I., Steinmetz, L.M., Moore, C., and Jensen, T.H. (2012). Supplemental Information Rrp6p Controls mRNA Poly ( A ) Tail Length and Its Decoration with Poly ( A ) Binding Proteins. 47, 1-29.

Schmid, M., Olszewski, P., Pelechano, V., Gupta, I., Steinmetz, L.M., and Jensen, T.H. (2015). The Nuclear PolyA-Binding Protein Nab2p Is Essential for mRNA Production. Cell Rep. 12, 128-139.

Schmitt, A.P., and McEntee, K. (1996). Msn2p, a zinc finger DNA-binding protein, is the transcriptional activator of the multistress response in Saccharomyces cerevisiae. Proc. Natl. Acad. Sci. U. S. A. 93, 5777-5782.

Schmitt, C., Von Kobbe, C., Bachi, A., Panté, N., Rodrigues, J.P., Boscheron, C., Rigaut, G., Wilm, M., Séraphin, B., Carmo-Fonseca, M., et al. (1999). Dbp5, a DEAD-box protein required for mRNA export, is recruited to the cytoplasmic fibrils of nuclear pore complex via a conserved interaction with CAN/Nup159p. EMBO J. 18, 4332-4347.

Schmitt, M.E., Brown, T.A., and Trumpower, B.L. (1990). A rapid and simple method for preparation of RNA from Saccharomyces cerevisiae. Nucleic Acids Res. 18, 30913092.

Segref, A., Sharma, K., Doye, V., Hellwig, A., Huber, J., Lührmann, R., and Hurt, E. (1997). Mex67p, a novel factor for nuclear mRNA export. Binds to both poly(A)+ RNA and nuclear pores. EMBO J. 16, 3256-3271.

Senger, B., Simos, G., Bischoff, F.R., Podtelejnikov, A., Mann, M., and Hurt, E. (1998). Mtr10p functions as a nuclear import receptor for the mRNA-binding protein Np13p. EMBO J. 17, 2196-2207.

Sharp, P.A., Sugden, B., and Sambrook, J. (1973). Detection of two restriction endonuclease activities in Haemophilus parainfluenzae using analytical agarose-ethidium bromide electrophoresis. Biochemistry 12, 3055-3063.

Shen, E.C., Henry, M.F., Weiss, V.H., Valentini, S.R., Silver, P.A., and Lee, M.S. (1998). Arginine methylation facilitates the nuclear export of hnRNP proteins. Genes Dev. 12, 679-691.

Shen, E.C., Stage-Zimmermann, T., Chui, P., and Silver, P. a. (2000). The Yeast mRNAbinding Protein Npl3p Interacts with the Cap-binding Complex. J. Biol. Chem. 275, $23718-23724$.

Sherman, F. (1991). [1] Getting started with yeast. Methods Enzymol. 194, 3-21.

Sherman, F., and Hicks, J. (1991). Micromanipulation and dissection of asci. Methods Enzymol. 194, 21-37.

Sheth, U., and Parker, R. (2003). Decapping and Decay of Messenger RNA Occur in Cytoplasmic Processing Bodies. Science (80-. ). 805-808.

Sheth, U., and Parker, R. (2006). Targeting of Aberrant mRNAs to Cytoplasmic Processing Bodies. Cell 125, 1095-1109. 
Shevchenko, A., Jensen, O.N., Podtelejnikov, A. V, Sagliocco, F., Wilm, M., Vorm, O., Mortensen, P., Boucherie, H., and Mann, M. (1996). Linking genome and proteome by mass spectrometry: large-scale identification of yeast proteins from two dimensional gels. Proc. Natl. Acad. Sci. U. S. A. 93, 14440-14445.

Shevchenko, A., Tomas, H., Havlis, J., Olsen, J. V, and Mann, M. (2006). In-gel digestion for mass spectrometric characterization of proteins and proteomes. Nat. Protoc. 1, 2856-2860.

Shirokikh, N.E., and Spirin, A.S. (2008). Poly(A) leader of eukaryotic mRNA bypasses the dependence of translation on initiation factors. Proc. Natl. Acad. Sci. U. S. A. 105, 10738-10743.

Sikorski, R., and Hieter, P. (1989). A System of Shuttle Vectors and Yeast Host Strains Designed for Efficient Manipulation of DNA in Saccharomyces ceratisiae. Genetics $122,19-27$.

Simpson, C.E., and Ashe, M.P. (2012). Adaptation to stress in yeast: to translate or not? Biochem. Soc. Trans. 40, 794-799.

Skružný, M., Schneider, C., Rácz, A., Weng, J., Tollervey, D., and Hurt, E. (2009). An endoribonuclease functionally linked to perinuclear mRNP quality control associates with the nuclear pore complexes. PLoS Biol. 7.

Slobodin, B., and Gerst, J.E. (2010). A novel mRNA affinity purification technique for the identification of interacting proteins and transcripts in ribonucleoprotein complexes. RNA 16, 2277-2290.

Smith, D.B., and Corcoran, L.M. (2001). Expression and purification of glutathione-Stransferase fusion proteins. Curr. Protoc. Mol. Biol. Chapter 16, Unit16.7.

Snay-Hodge, C. a, Colot, H. V, Goldstein, A L., and Cole, C.N. (1998). Dbp5p/Rat8p is a yeast nuclear pore-associated DEAD-box protein essential for RNA export. EMBO J. 17, 2663-2676.

Solé, C., Nadal-Ribelles, M., Kraft, C., Peter, M., Posas, F., and de Nadal, E. (2011). Control of Ubp3 ubiquitin protease activity by the Hog1 SAPK modulates transcription upon osmostress. EMBO J. 30, 3274-3284.

Sorger, P.K. (1990). Yeast heat shock factor contains separable transient and sustained response transcriptional activators. Cell 62, 793-805.

Sorger, P.K., and Pelham, H.R. (1987). Purification and characterization of a heat-shock element binding protein from yeast. EMBO J. 6, 3035-3041.

Soucek, S., Corbett, A.H., and Fasken, M.B. (2012). The long and the short of it: the role of the zinc finger polyadenosine RNA binding protein, Nab2, in control of poly(A) tail length. Biochim. Biophys. Acta 1819, 546-554.

Spingola, M., Grate, L., Haussler, D., and Ares, M. (1999). Genome-wide bioinformatic and molecular analysis of introns in Saccharomyces cerevisiae. RNA 5, 221-234.

Sprague, G.F. (1991). Assay of yeast mating reaction. Methods Enzymol. 194, 77-93.

Stewart, M. (2010). Nuclear export of mRNA. Trends Biochem. Sci. 35, 609-617. 
Strahm, Y., Fahrenkrog, B., Zenklusen, D., Rychner, E., Kantor, J., and Rosbash, M. (1999). The RNA export factor Gle1p is located on the cytoplasmic fibrils of the NPC and physically interacts with the FG-nucleoporin Rip1p , the DEAD-box protein Rat8p / Dbp5p and a new protein Ymr255p. 18, 5761-5777.

Strässer, K., and Hurt, E. (2001). Splicing factor Sub2p is required for nuclear mRNA export through its interaction with Yra1p. - PubMed - NCBI.

Sträßer, K., Baßler, J., and Hurt, E. (2000). Binding of the Mex67p/Mtr2p heterodimer to FXFG, GLFG, and FG repeat nucleoporins is essential for nuclear mRNA export. J. Cell Biol. 150, 695-706.

Strässer, K., Masuda, S., Mason, P., Pfannstiel, J., Oppizzi, M., Rodriguez-Navarro, S., Rondón, A.G., Aguilera, A., Struhl, K., Reed, R., et al. (2002). TREX is a conserved complex coupling transcription with messenger RNA export. Nature 417, 304-308.

Strawn, L., Shen, T., and Wente, S.R. (2001). The GLFG Regions of Nup116p and Nup100p Serve as Binding Sites for Both Kap95p and Mex67p at the Nuclear Pore Complex. J. Biol. Chem. 276, 6445-6452.

Tamai, K.T., Liu, X., Silar, P., Sosinowski, T., and Thiele, D.J. (1994). Heat shock transcription factor activates yeast metallothionein gene expression in response to heat and glucose starvation via distinct signalling pathways. Mol. Cell. Biol. 14, 8155-8165.

Tani, T., Derby, R.J., Hiraoka, Y., and Spector, D.L. (1996). Nucleolar accumulation of poly (A)+ RNA in heat-shocked yeast cells: implication of nucleolar involvement in mRNA transport. Mol. Biol. Cell 7, 173-192.

Taura, T., Krebber, H., and Silver, P.A. (1998). A member of the Ran-binding protein family, Yrb2p, is involved in nuclear protein export. Proc. Natl. Acad. Sci. U. S. A. 95, 7427-7432.

Teixeira, D., Sheth, U., Valencia-Sanchez, M.A., Brengues, M., and Parker, R. (2005). Processing bodies require RNA for assembly and contain nontranslating mRNAs. RNA $11,371-382$.

Terry, L.J., and Wente, S.R. (2007). Nuclear mRNA export requires specific FG nucleoporins for translocation through the nuclear pore complex. J. Cell Biol. 178, 1121-1132.

Terry, L.J., and Wente, S.R. (2009). Flexible gates: Dynamic topologies and functions for FG nucleoporins in nucleocytoplasmic transport. Eukaryot. Cell 8, 1814-1827.

Thayer, N.H., Leverich, C.K., Fitzgibbon, M.P., Nelson, Z.W., Henderson, K., Gafken, P.R., Hsu, J.J., and Gottschling, D.E. (2014). Identification of long-lived proteins retained in cells undergoing repeated asymmetric divisions. Proc. Natl. Acad. Sci. U. S. A. 111, 14019-14026.

Thomsen, R., Libri, D., Boulay, J., Rosbash, M., and Jensen, T.H. (2003). Localization of nuclear retained mRNAs in Saccharomyces cerevisiae. RNA 9, 1049-1057.

Tieg, B., and Krebber, H. (2012). Dbp5 - From nuclear export to translation. Biochim. Biophys. Acta - Gene Regul. Mech. 1829, 791-798.

Towbin, H., Staehelin, T., and Gordon, J. (1979). Electrophoretic transfer of proteins from polyacrylamide gels to nitrocellulose sheets: procedure and some applications. Proc. Natl. Acad. Sci. U. S. A. 76, 4350-4354. 
Tran, E.J., Zhou, Y., Corbett, A.H., and Wente, S.R. (2007). The DEAD-box protein Dbp5 controls mRNA export by triggering specific RNA:protein remodeling events. Mol. Cell 28, 850-859.

Trott, A., and Morano, K.A. (2003). The yeast response to heat shock. In Yeast Stress Responses, S. Hohmann, and W.H. Mager, eds. (Berlin, Heidelberg: Springer Berlin Heidelberg), pp. 71-119.

Tseng, S.S.I., Weaver, P.L., Liu, Y., Hitomi, M., Tartakoff, A.M., and Chang, T.H. (1998). Dbp5p, a cytosolic RNA helicase, is required for poly(A)+ RNA export. EMBO J. 17, 2651-2662.

Tsvetanova, N.G., Klass, D.M., Salzman, J., and Brown, P.O. (2010). Proteome-wide search reveals unexpected RNA-binding proteins in Saccharomyces cerevisiae. PLoS One 5 , e12671.

Tutucci, E., and Stutz, F. (2011). Keeping mRNPs in check during assembly and nuclear export. Nat. Rev. Mol. Cell Biol. 12, 377-384.

Twyffels, L., Gueydan, C., and Kruys, V. (2011). Shuttling SR proteins: more than splicing factors. FEBS J. 278, 3246-3255.

Vaňáčová, Š., Wolf, J., Martin, G., Blank, D., Dettwiler, S., Friedlein, A., Langen, H., Keith, G., and Keller, W. (2005). A new yeast poly(A) polymerase complex involved in RNA quality control. PLoS Biol. 3, 0986-0997.

Verghese, J., Abrams, J., Wang, Y., and Morano, K. (2012). Biology of the Heat Shock Response and Protein Chaperones: Budding Yeast (Saccharomyces cerevisiae) as a Model System. Microbiol. Mol. Biol. Rev. 76, 115-158.

Vinciguerra, P., Iglesias, N., Camblong, J., Zenklusen, D., and Stutz, F. (2005). Perinuclear Mlp proteins downregulate gene expression in response to a defect in mRNA export. EMBO J. 24, 813-823.

Viphakone, N., Voisinet-Hakil, F., and Minvielle-Sebastia, L. (2008). Molecular dissection of mRNA poly(A) tail length control in yeast. Nucleic Acids Res. 36, 24182433.

Wahl, M.C., Will, C.L., and Luhrmann, R. (2009). The Spliceosome: Design Principles of a Dynamic RNP Machine. Cell 136, 701-718.

Wallace, E.W.J., Kear-Scott, J.L., Pilipenko, E.V., Schwartz, M.H., Laskowski, P.R., Rojek, A.E., Katanski, C.D., Riback, J.A., Dion, M.F., Franks, A.M., et al. (2015). Reversible, Specific, Active Aggregates of Endogenous Proteins Assemble upon Heat Stress. Cell 162, 1286-1298.

Walters, R.W., Muhlrad, D., Garcia, J., and Parker, R.O.Y. (2015). Differential effects of Ydj1 and Sis1 on Hsp70-mediated clearance of stress granules in Saccharomyces cerevisiae. $1-12$.

Wang, X., Jia, H., Jankowsky, E., and Anderson, J.T. (2008). Degradation of hypomodified tRNA(iMet) in vivo involves RNA-dependent ATPase activity of the DExH helicase Mtr4p. RNA 14, 107-116.

Weaver, P.L., Sun, C., and Chang, T.H. (1997). Dbp3p, a putative RNA helicase in Saccharomyces cerevisiae, is required for efficient pre-rRNA processing predominantly at site A3. Mol. Cell. Biol. 17, 1354-1365. 
Weber, V., Wernitznig, A., Hager, G., Harata, M., Frank, P., and Wintersberger, U. (1997). Purification and nucleic-acid-binding properties of a Saccharomyces cerevisiae protein involved in the control of ploidy. Eur. J. Biochem. 249, 309-317.

Weirich, C.S., Erzberger, J.P., Flick, J.S., Berger, J.M., Thorner, J., and Weis, K. (2006). Activation of the DExD/H-box protein Dbp5 by the nuclear-pore protein Gle1 and its coactivator InsP6 is required for mRNA export. Nat. Cell Biol. 8, 668-676.

Wente, S.R., and Rout, M.P. (2010). The nuclear pore complex and nuclear transport. Cold Spring Harb. Perspect. Biol. 2.

De Wever, V., Reiter, W., Ballarini, A., Ammerer, G., and Brocard, C. (2005). A dual role for PP1 in shaping the Msn2-dependent transcriptional response to glucose starvation. EMBO J. 24, 4115-4123.

Wieser, R., Adam, G., Wagner, A., Schüller, C., Marchler, G., Ruis, H., Krawiec, Z., and Bilinski, T. (1991). Heat shock factor-independent heat control of transcription of the CTT1 gene encoding the cytosolic catalase T of Saccharomyces cerevisiae. J. Biol. Chem. 266, 12406-12411.

Will, C.L., and Lührmann, R. (2011). Spliceosome structure and function. Cold Spring Harb. Perspect. Biol. 3, 1-2.

Wilmes, G.M., Bergkessel, M., Bandyopadhyay, S., Shales, M., Braberg, H., Cagney, G., Collins, S.R., Whitworth, G.B., Kress, T.L., Weissman, J.S., et al. (2008). A genetic interaction map of RNA-processing factors reveals links between Sem1/Dss1containing complexes and mRNA export and splicing. Mol. Cell 32, 735-746.

Windgassen, M., and Krebber, H. (2003). Identification of Gbp2 as a novel poly(A)+ RNA-binding protein involved in the cytoplasmic delivery of messenger RNAs in yeast. EMBO Rep. 4, 278-283.

Windgassen, M., Sturm, D., Cajigas, I.J., González, C.I., Seedorf, M., Bastians, H., and Krebber, H. (2004). Yeast shuttling SR proteins Npl3p, Gbp2p, and Hrb1p are part of the translating mRNPs, and Npl3p can function as a translational repressor. Mol. Cell. Biol. 24, 10479-10491.

Wong, C.M., Tang, H.M.V., Kong, K.Y.E., Wong, G.W.O., Qiu, H., Jin, D.Y., and Hinnebusch, A.G. (2010). Yeast arginine methyltransferase Hmt1p regulates transcription elongation and termination by methylating Npl3p. Nucleic Acids Res. 38, 2217-2228.

Wu, H., Becker, D., and Krebber, H. (2014). Telomerase RNA TLC1 Shuttling to the Cytoplasm Requires mRNA Export Factors and Is Important for Telomere Maintenance. Cell Rep. 8, 1630-1638.

Wyers, F., Rougemaille, M., Badis, G., Rousselle, J.C., Dufour, M.E., Boulay, J., Régnault, B., Devaux, F., Namane, A., Séraphin, B., et al. (2005). Cryptic Pol II transcripts are degraded by a nuclear quality control pathway involving a new poly(A) polymerase. Cell 121, 725-737.

Yamamoto, A., Mizukami, Y., and Sakurai, H. (2005). Identification of a novel class of target genes and a novel type of binding sequence of heat shock transcription factor in Saccharomyces cerevisiae. J. Biol. Chem. 280, 11911-11919. 
Yamamoto, N., Maeda, Y., Ikeda, A., and Sakurai, H. (2008). Regulation of Thermotolerance by Stress-Induced Transcription Factors in Saccharomyces cerevisiae. Eukaryot. Cell 7, 783-790.

Yao, W., Roser, D., Köhler, A., Bradatsch, B., Baßler, J., Hurt, E., (2007). Nuclear export of ribosomal 60S subunits by the general mRNA export receptor Mex67-Mtr2. Mol. Cell 26, 51-62.

Yost, H., and Lindquist, S. (1991). Heat shock proteins affect RNA processing during the heat shock response of. Mol. Cell. Biol. 11, 1062-1068.

Yun, C.Y., and Fu, X.D. (2000). Conserved SR protein kinase functions in nuclear import and its action is counteracted by arginine methylation in Saccharomyces cerevisiae. J. Cell Biol. 150, 707-718.

Zander G., Hackmann, A., Bender L., Becker D., Lingner T., Salinas G., and Krebber H., (2016). mRNA quality control is bypassed for an immediate export of stress responsive transcripts. Nature, accepted.

Zenklusen, D., Vinciguerra, P., and Strahm, Y. (2001). The Yeast hnRNP-Like Proteins Yra1p and Yra2p Participate in mRNA Export through Interaction with Mex67p. 21, 4219-4232.

Zenklusen, D., Vinciguerra, P., and Wyss, J. (2002). Stable mRNP Formation and Export Require Cotranscriptional Recruitment of the mRNA Export Factors Yra1p and Sub2p by Hpr1p Stable mRNP Formation and Export Require Cotranscriptional Recruitment of the mRNA Export Factors Yra1p and Sub2p by Hpr1p. Mol. Cell. Biol. 22, 82418253.

Zhao, X., Wu, C.Y., and Blobel, G. (2004). Mlp-dependent anchorage and stabilization of a desumoylating enzyme is required to prevent clonal lethality. J. Cell Biol. 167, 605611.

Zid, B.M., and O'Shea, E.K. (2014). Promoter sequences direct cytoplasmic localization and translation of mRNAs during starvation in yeast. Nature $514,117-121$. 


\section{Abkürzungen}

AS

APS

ATP

bp

bzw.

ct-Wert

DNA

dNTP

FOA

g

GDP

GTP

GFP

HRP

$\mathrm{kb}$

mRNA

mRNP

OD

PCR

rRNA

SDS-PAGE

tRNA

u. a.

$\mathrm{v} / \mathrm{v}$

$\mathrm{w} / \mathrm{v}$

Z. B.
Amionsäurerest

Ammoniumpersulfat

Adenosintriphosphat

Basenpaare

beziehungsweise

„cycle threshold“"Wert

Desoxyribonukleinsäure

Desoxyribonukleosidtriphosphat

5-Fluoroorotsäure

Erdbeschleunigung

Guanosindiphosphat

Guanosintriphosphat

grün-fluoreszierendes Protein

Meerrettich-Peroxidase

Kilobasenpaare

„messenger ribonucleo acid“

„messenger ribonucleoprotein particle“

optische Dichte

Polymerasekettenreaktion

„ribosomal ribonucleo acid“

Sodiumdodecylsulfat-Polyacrylamid-

Gelelektrophorese

„transfer ribonucleo acid““

unter anderem

Volumen pro Volumen

Gewicht pro Volumen

zum Beispiel 


\section{Danksagung}

Ich möchte mich bei allen Personen ganz herzlich bedanken, die mich während meiner Doktorarbeit unterstützt und mit zur Seite gestanden haben. Allen voran geht ein besonderer Dank an Prof. Dr. Heike Krebber, die mir die Möglichkeit gab in ihrem Labor interessante Themen $\mathrm{zu}$ bearbeiten sowie für die zahlreichen anregenden Diskussionen, ihre enge Betreuung, ihr Vertrauen und die wissenschaftliche Förderung. Weiterhin bedanke ich mich bei Prof. Dr. Gerhard Braus als Mitglied meines Betreuungsausschusses für die Begleitung meiner Doktorarbeit, für seine Unterstützung und die wertvollen Anmerkungen.

Ein herzlicher Dank geht an die AG Braus und die AG Ficner, die durch das Bereitstellen von Geräten, Stämmen und Plasmiden diese Arbeit sehr unterstützt haben.

Ich bedanke mich herzlich bei Gesa Zander und Dr. Alexandra Hackmann für die gute Zusammenarbeit an diesem Projekt. Des Weiteren danke ich den von mir betreuten Studenten Astrid-Solveig Schultz und Berfin Tuku, die durch ihre Versuche und ihr großartiges Engagement auch zum Gelingen dieser Doktorarbeit beigetragen haben. Vielen Dank allen aktuellen und ehemaligen Mitgliedern der AG Krebber für ihre tatkräftige Unterstützung bei den Belangen rund um das Labor, den wunderbaren Zusammenhalt und die unzähligen hilfreichen Diskussionen. Dr. Wilfried Kramer danke ich vor allem für sein kritisches Nachfragen und seine guten Ideen. Ebenso danke ich Lena Oldehaver und Daniel Becker für die sehr angenehme gemeinsame Zeit im Labor. Natürlich möchte ich mich ganz besonders bei Dr. Claudia Baierlein und Dr. Bettina Neumann bedanken, die mir nicht nur wissenschaftlich mit Rat und Tat zur Seite standen und jederzeit ein offenes Ohr für mich hatten, sondern mich auch darüber hinaus sehr unterstützt haben - Tausend Dank!

Für das Korrekturlesen dieser Arbeit danke ich sehr Prof. Dr. Heike Krebber, Dr. Claudia Baierlein, Dr. Bettina Neumann, Gesa Zander, Daniel Becker und Mirja Wagner.

Auch möchte ich mich ganz herzlich bei meinen Familien, meinen Freunden und besonders bei Marcus bedanken, dass ihr mir liebevoll zur Seite standet, an mich geglaubt und mich motiviert habt. Ohne Euch hätte ich es nicht geschafft. Bedanken möchte ich mich auch bei allen Bewohnern der Königsallee 30 bis 34. Ihr habt mit mir diese Zeit gerockt, vielen Dank! 


\title{
Promovierenden-Erklärung der Georg-August-Universität Göttingen
}

\author{
Bender, Lysann \\ Hamburger Hochstraße 19, \\ 20359 Hamburg
}

Ich habe eine Dissertation zum Thema: Charakterisierung des mRNA-Exportweges bei zellulärem Stress in Saccharomyces cerevisiae an der Georg-August-Universität Göttingen angefertigt. Dabei wurde ich von Frau Prof. Dr. Heike Krebber betreut.

Ich gebe folgende Erklärung ab:

1. Die Gelegenheit zum vorliegenden Promotionsvorhaben ist mir nicht kommerziell vermittelt worden. Insbesondere habe ich keine Organisation eingeschaltet, die gegen Entgelt Betreuerinnen und Betreuer für die Anfertigung von Dissertationen sucht oder die mir obliegenden Pflichten hinsichtlich der Prüfungsleistungen für mich ganz oder teilweise erledigt.

2. Hilfe Dritter wurde bis jetzt und wird auch künftig nur in wissenschaftlich vertretbarem und prüfungsrechtlich zulässigem Ausmaß in Anspruch genommen. Insbesondere wurden alle Teile der Dissertation selbst angefertigt; unzulässige fremde Hilfe habe ich dazu weder unentgeltlich noch entgeltlich entgegengenommen und werde dies auch zukünftig so halten. 3. Die Ordnung zur Sicherung der guten wissenschaftlichen Praxis an der Universität Göttingen wurde von mir beachtet.

4. Eine entsprechende Promotion wurde an keiner anderen Hochschule im In- oder Ausland beantragt; die eingereichte Dissertation oder Teile von ihr wurden nicht für ein anderes Promotionsvorhaben verwendet.

Mir ist bekannt, dass unrichtige Angaben die Zulassung zur Promotion ausschließen bzw. später zum Verfahrensabbruch oder zur Rücknahme des erlangten Grades führen.

Hamburg, den 31.05.2016

(Unterschrift) 
